\title{
10. MINERALOGY AND MINERAL CHEMISTRY OF HYDROTHERMALLY ALTERED SEDIMENT, MIDDLE VALLEY, JUAN DE FUCA RIDGE ${ }^{1}$
}

\author{
Matthew I. Leybourne ${ }^{2}$ and Wayne D. Goodfellow ${ }^{2}$
}

\begin{abstract}
Two hydrothermal upflow zones and a hydrothermal reaction zone were drilled in Middle Valley, a sedimented rift valley at the northern end of the Juan de Fuca Ridge, during Leg 139 of the Ocean Drilling Program. Site 856 (Bent Hill; BH) is a fossil high-temperature hydrothermal system that hosts massive sulfides, Site 858 (Area of Active Venting; AAV) is an active hydrothermal system venting fluids up to $276^{\circ} \mathrm{C}$, and Site 857 is a hydrothermal reaction zone south of AAV. Alteration at BH is zoned laterally away from a high-temperature, silicified, brecciated, and veined core that consists of quartz-(Fe)chlorite-muscoviterutile-chalcopyrite-pyrrhotite (Zone Ia). Surrounding Zone Ia are altered sediments that are zoned away from the core as follows. Zone IIa consists of albite-chlorite-pyrite alteration of moderately indurated and brecciated sediment. Zones IIIIa and IVa are characterized by hydrothermal anhydrite and calcite, respectively, in addition to illite and pyrite, and are less intensely indurated than sediments from the inner, higher temperature zones.

Sediments near the center of hydrothermal fluid discharge at AAV are lithified, brecciated, and veined, and consist of the assemblage wairakite-quartz-epidote-sphene-pyrite (Zone Ib). Zone Ib is surrounded by alteration zones that are progressively less altered away from centers of fluid discharge. From the core outward, these are: Zone IIlb (quartz-epidote-pyrite); Zone IIIb (albite-chlorite-pyrite); Zone IVb (anhydrite-illite-pyrite); and Zone Vb (calcite/dolomite-illite-pyrite). Sediments intercalated with mafic sills below 460 meters below sea-floor at Site 857 are mineralogically similar to Zones $\mathrm{Ib}$ and IIb at AAV, suggesting that the hydrothermal fluid venting at AAV was generated in a hydrothermal reaction zone in the basal parts of the Middle Valley sedimentary sequence.

The mineralogical differences between the core assemblages at the BH and AAV hydrothermal upflow systems are a function of hydrothermal fluid temperature and composition. Fluid inclusions and chlorite chemistry of Zone Ia suggest that the Bent Hill massive sulfide deposit was produced by high-temperature $\left(300^{\circ}-400^{\circ} \mathrm{C}\right)$ fluid. The absence of Ca-bearing hydrothermal phases and the destruction of detrital $\mathrm{Ca}$-minerals indicate that the end-member hydrothermal fluids at $\mathrm{BH}$ were probably depleted in $\mathrm{Ca}$ relative to AAV fluids.

Vent fluid $\left(184^{\circ}-276^{\circ} \mathrm{C}\right)$ and fluid inclusion $\left(270^{\circ}-290^{\circ} \mathrm{C}\right)$ temperatures clearly show that AAV is a lower-temperature hydrothermal system. The occurrence of wairakite, anorthitic plagioclase, epidote, and sphene that formed at the expense of detrital $\mathrm{K}$-bearing minerals is consistent with fluid $\mathrm{Ca}$ contents that are higher than for basalt-equilibrated, end-member hydrothermal fluids. At BH and AAV, the mineral zonation and temperature gradients are controlled by the mixing of entrained seawater with upwelling hydrothermal fluid. The convex-up pattern of mineral zonation about both upflow zones is consistent with fluid inclusion temperatures, pore water compositions, and bulk sediment compositions.
\end{abstract}

\section{INTRODUCTION}

Middle Valley, a sediment-covered rift near the northern end of the Juan de Fuca Ridge, has been the focus of extensive geophysical and geological research over the past decade with the discovery of high heat flow (Davis and Lister, 1977; Davis, Goodfellow, et al., 1987) and associated massive sulfide deposits (Adshead et al., 1986; Davis, Goodfellow, et al., 1987; Goodfellow and Blaise, 1988; Goodfellow and Franklin, in press). Two hydrothermal centers have been investigated intensively: the Area of Active Venting (AAV; Site 858), which has active chimneys venting $184^{\circ}-276^{\circ} \mathrm{C}$ fluids (Davis, Mottl, Fisher, et al., 1992), and Bent Hill (BH; Site 856), where sulfide mounds have been mapped and sampled by submersible, dredging, and coring (Fig. 1). Both of these areas, a hydrothermal reaction zone (Site 857), and relatively unaltered hemipelagic and turbiditic sediment near the eastern margin of the valley (Site 855) were cored during Ocean Drilling Program (ODP) Leg 139 in order to better understand hydrothermal processes in sedimented rifts.

The objectives of this study were to document the mineralogy and mineral chemistry in hydrothermal fluid upflow and reaction zones,

\footnotetext{
'Mottl, M.J., Davis, E.E., Fisher, A.T., and Slack, J.F. (Eds.), 1994. Proc. ODP, Sci. Results, 139: College Station, TX (Ocean Drilling Program)

${ }^{2}$ Mineral Resources Division, Geological Survey of Canada, 601 Booth Street, Ottawa, Ontario, Canada K1A 0E8.
}

to relate mineralogical changes to temperature and distance from fluid upflow zones, and to place physical and chemical constraints on fluidsediment reaction conditions. Previous work on shallow sediment and sulfide cores that penetrated the mound structures in Middle Valley have documented the near-surface mineralogical and chemical zoning about active and fossil upflow zones (Goodfellow and Blaise, 1988; Goodfellow et al., in press; Goodfellow and Franklin, in press). Deep cores recovered during Leg 139 allow us to examine the third dimension, with an emphasis on the deeper portions of hydrothermal upflow (Sites 856 and 858) and reaction zones (Site 857).

\section{GEOLOGICAL SETTING}

Four sites were drilled in Middle Valley during ODP Leg 139 (Fig. 1). Site 856 is known from previous work (Davis, Goodfellow, et al., 1987; Goodfellow and Blaise, 1988; Goodfellow et al., in press; Goodfellow and Franklin, in press) to be an inactive hydrothermal upflow zone with an associated massive sulfide deposit (BH). Site 858 is a vent field with hydrothermal fluids venting from anhydrite chimneys on sediment mounds (Goodfellow et al., in press; Goodfellow and Franklin, in press). The vent field is characterized by heat flow values $>1 \mathrm{Wm}^{-2}$ (Davis and Villinger, 1992). Site 857 was drilled to better understand the hydrology and the depth and conditions of hydrothermal fluid reaction whereas Site 855 was drilled to evaluate whether fluid recharge was occurring at the margins of the rift (Davis, Mottl, Fisher, et al., 1992; Davis and Villinger, 1992). 


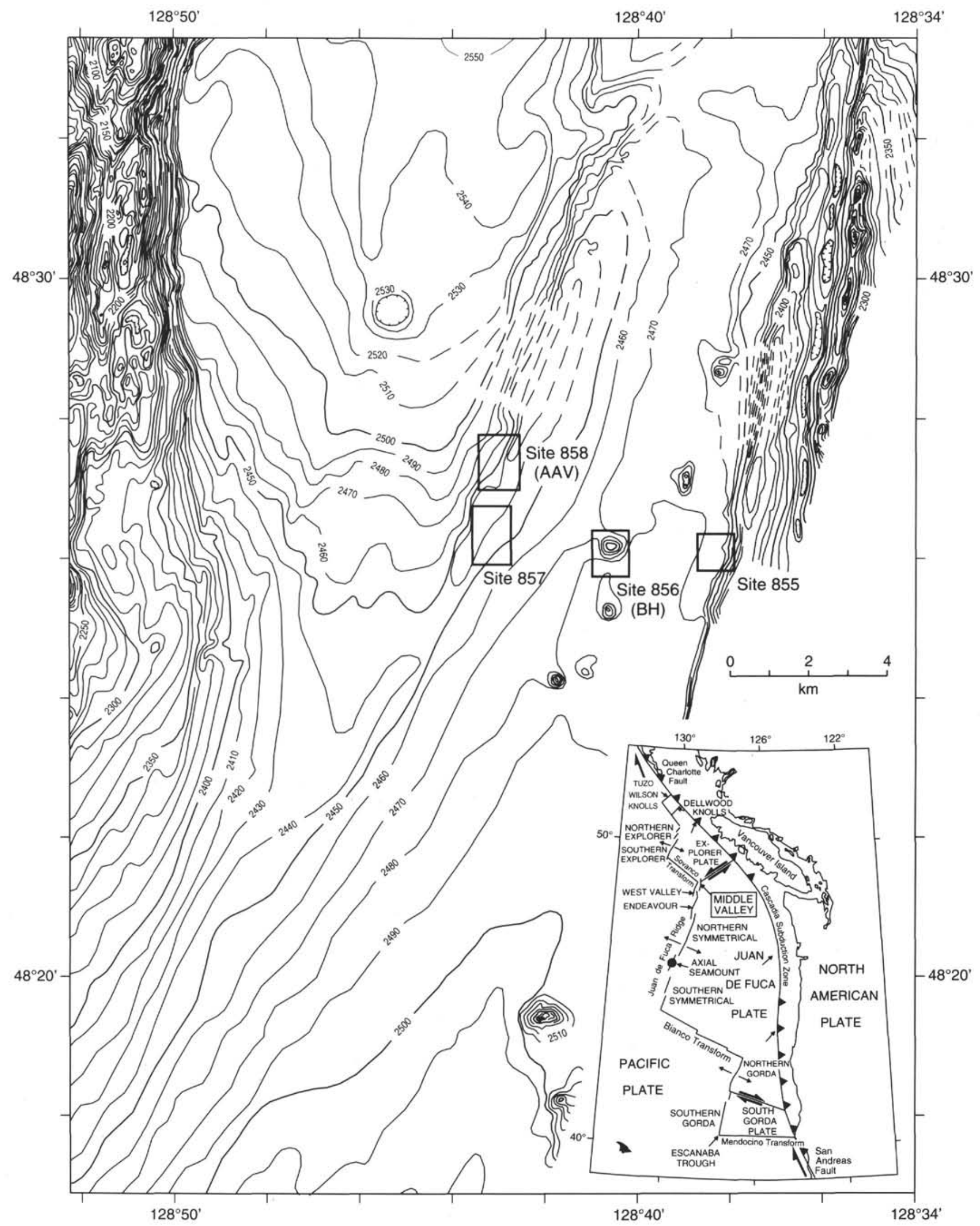

Figure 1. Seabeam bathymetry of Middle Valley showing the Leg 139 site locations (Davis, Currie, Sawyer, 1987; Davis, Mottl, Fisher, et al., 1992). AAV = Area of Active Venting, BH = Bent Hill. Inset map shows the location of Middle Valley at the northern end of the Juan de Fuca Ridge. 

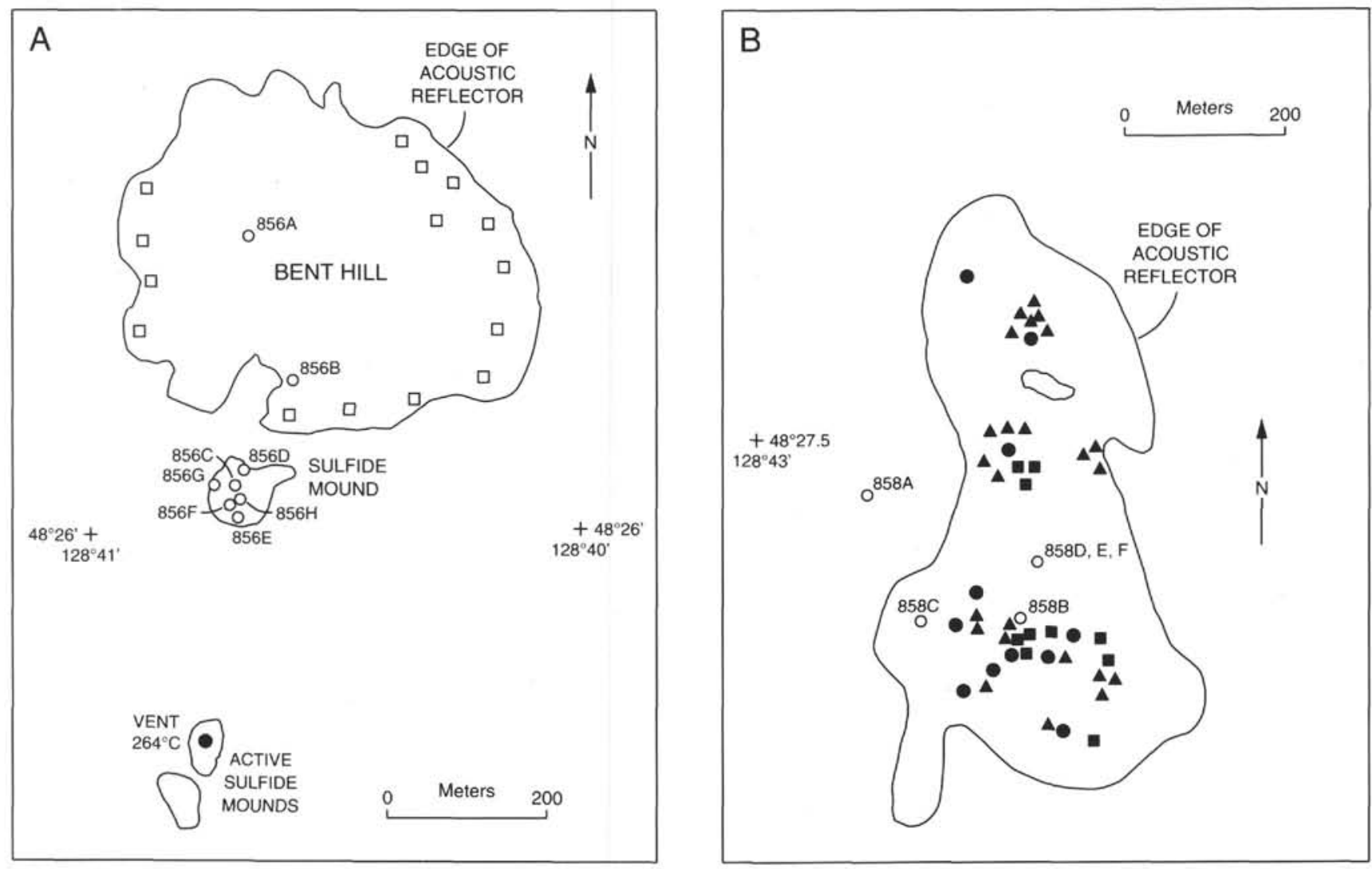

LEGEND
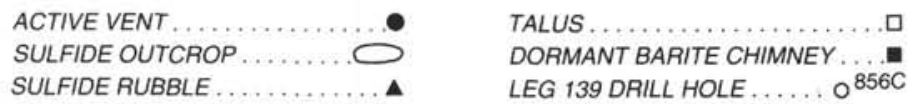

Figure 2. Maps showing the locations of drill holes, active vents and mounds, and sulfide outcrops. A. Site 856. B. Site 858.

\section{Site 856 (Bent Hill)}

Bent Hill is a $500-\mathrm{m}$ diameter and $60-\mathrm{m}$ high mound structure located $3 \mathrm{~km}$ from the eastern margin of Middle Valley (Fig. 1). A smaller (100-m-wide, 35-m-high) mound of massive sulfide occurs near the southern margin of BH. Further to the south are two small (25-m-high) sulfide mounds, one venting $264^{\circ} \mathrm{C}$ fluids from anhydritesulfide chimneys (Goodfellow and Franklin, in press). Eight holes were drilled at Site 856, and samples from seven of these holes were studied. Holes 856A and 856B are from the top and southern edge of Bent Hill and Holes $856 \mathrm{D}$ to $856 \mathrm{H}$ were collared near the summit of the sulfide mound at the southern margin of Bent Hill (Fig. 2A).

Hole $856 \mathrm{~A}$ consists of interbedded hemipelagic and turbiditic sediments (Fig. 3). Sediments in the upper part of Hole 856A are unconsolidated ( $0-5$ meters below seafloor; mbsf) to weakly indurated ( $5-25 \mathrm{mbsf})$. Below $25 \mathrm{mbsf}$, sediments become more indurated and change color with depth. The sediments are dominantly olivegrey to $12 \mathrm{mbsf}$, olive-grey to blue-green between 12 and $60 \mathrm{mbsf}$, and medium to dark grey from $60 \mathrm{mbsf}$ to the bottom of the hole. Turbidite sequences are commonly thinly laminated and less indurated than hemipelagic silty clay. A mafic sill was encountered at the base of the hole (112 mbsf) although no thermal affects in the overlying sediment were observed (Davis, Mottl, Fisher, et al., 1992).

Hole $856 \mathrm{~B}$ intersected $121.7 \mathrm{~m}$ of hemipelagic and turbiditic sediment (Fig. 4). The uppermost 17.5 meters of Hole 856B is dominated by relatively unaltered, unconsolidated to weakly indurated medium-grey sediment. Unconsolidated clastic sulfides occur between 18.39 and $24.17 \mathrm{mbsf}$, and turbiditic sediment with variable sulfide contents between 24.17 and $26.31 \mathrm{mbsf}$. The sulfide sediment is interpreted to have formed by the slumping of sulfide debris from the adjacent sulfide mound (Davis, Mottl, Fisher, et al., 1992). Sediments are fractured and brecciated and contain disseminated pyrite between 27 and $77 \mathrm{mbsf}$. Two types of breccia are recognized: crackle breccia composed of angular, moderately indurated, clast-supported, medium-grey sediment; and matrix-supported channelway breccia with rounded to subrounded clasts of silty clay (Davis, Mottl, Fisher, et al., 1992). The sediments become increasingly indurated and the color changes from light grey to bluish-grey between $77 \mathrm{mbsf}$ and the mafic sill near bottom of the hole. A 5-6-m-thick mafic sill was also intersected at 62 mbsf (Davis, Mottl, Fisher, et al., 1992).

Sulfide minerals from Holes $856 \mathrm{D}$ through $856 \mathrm{H}$ are predominantly pyrrhotite, pyrite, sphalerite, chalcopyrite, isocubanite, and less commonly marcasite and galena. Secondary magnetite after pyrrhotite is a major phase in Holes $856 \mathrm{G}$ and $856 \mathrm{H}$. Only carbonate and silicate minerals interstitial to sulfides, and veined and altered sediment between 25 and $30 \mathrm{mbsf}$ in Hole $856 \mathrm{H}$, are considered here as the detailed sulfide mineralogy is described elsewhere (Duckworth et al., this volume).

\section{Site 858 (Area of Active Venting)}

Site 858 is an active vent field $2.4 \mathrm{~km}$ northwest of Site 856 and $1.5 \mathrm{~km}$ east of a rift-parallel extensional fault (Fig. 1). The vent field is $800 \mathrm{~m}$ by $400 \mathrm{~m}$ and hosts at least 15 active vent sites with anhydrite chimneys that are discharging fluids with temperatures between $184^{\circ}$ and $276^{\circ} \mathrm{C}$ (Davis, Mottl, Fisher, et al., 1992). Seven holes were 


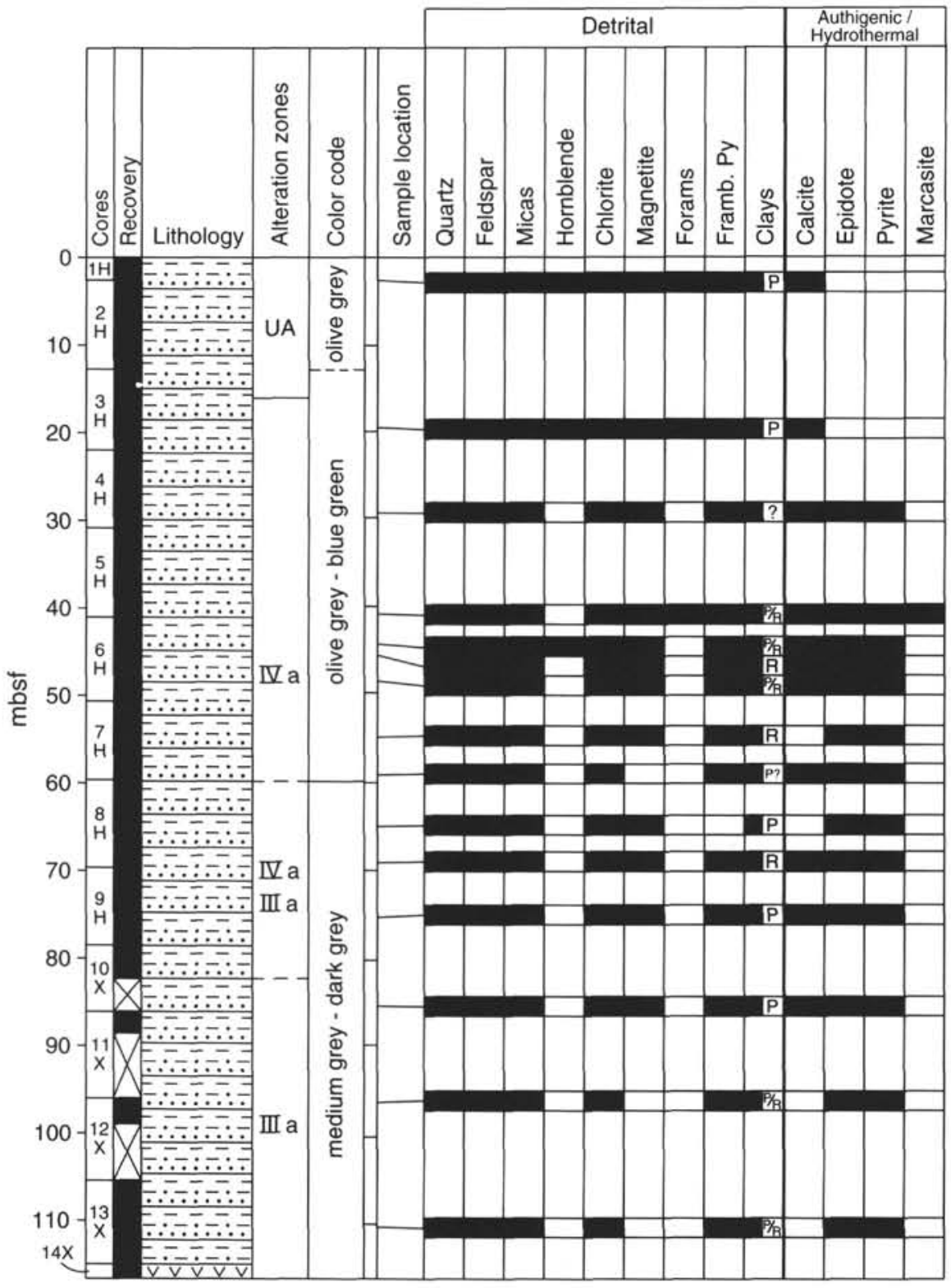

LEGEND
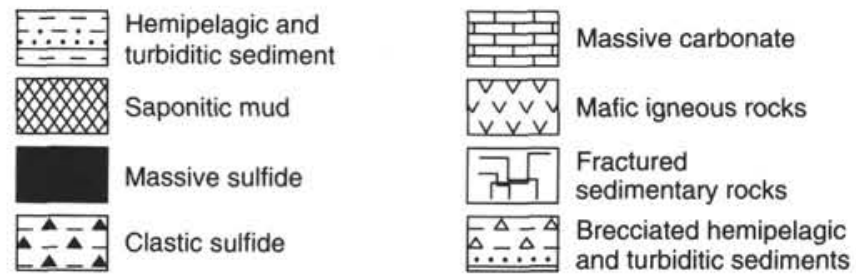

Figure 3. Stratigraphic section of Hole 856A showing the general sedimentology, alteration zones, and detrital, authigenic, and hydrothermal minerals based on thin-section descriptions. $\mathrm{UA}=$ unaltered sediment. Letter designates clay recrystallization: $\mathrm{P}=$ partial; $\mathrm{R}=$ recrystallized. Black $=$ present.

drilled at Site 858 and samples from five holes are described here (Fig. 2B). Holes $858 \mathrm{~A}, 858 \mathrm{C}, 858 \mathrm{D}, 858 \mathrm{~F}$, and $858 \mathrm{~B}$ traverse the vent field from the outer western margin to the center of hydrothermal fluid upflow (Fig. 2B). Hole 858B was drilled to a depth of $38.6 \mathrm{mbsf}$ within a few meters of a $276^{\circ} \mathrm{C}$ hydrothermal vent, whereas Holes $858 \mathrm{D}$ and $858 \mathrm{~F}$ were drilled to a depth of $296.9 \mathrm{mbsf} 70 \mathrm{~m}$ northeast of Hole 858B.
Hole $858 \mathrm{~A}$ intersected $339.1 \mathrm{~m}$ of hemipelagic and laminated to cross-laminated turbiditic sediments (Fig. 5). Hemipelagic and turbiditic sediments are unconsolidated to weakly indurated near the seafloor ( 0 to $29 \mathrm{mbsf}$ ), but are weakly to moderately indurated between 29 and $71 \mathrm{mbsf}$, and moderately indurated to lithified between 71 and $339.1 \mathrm{mbsf}$. An increase in the degree of induration with depth is accompanied by changes in sediment color, from greenish 


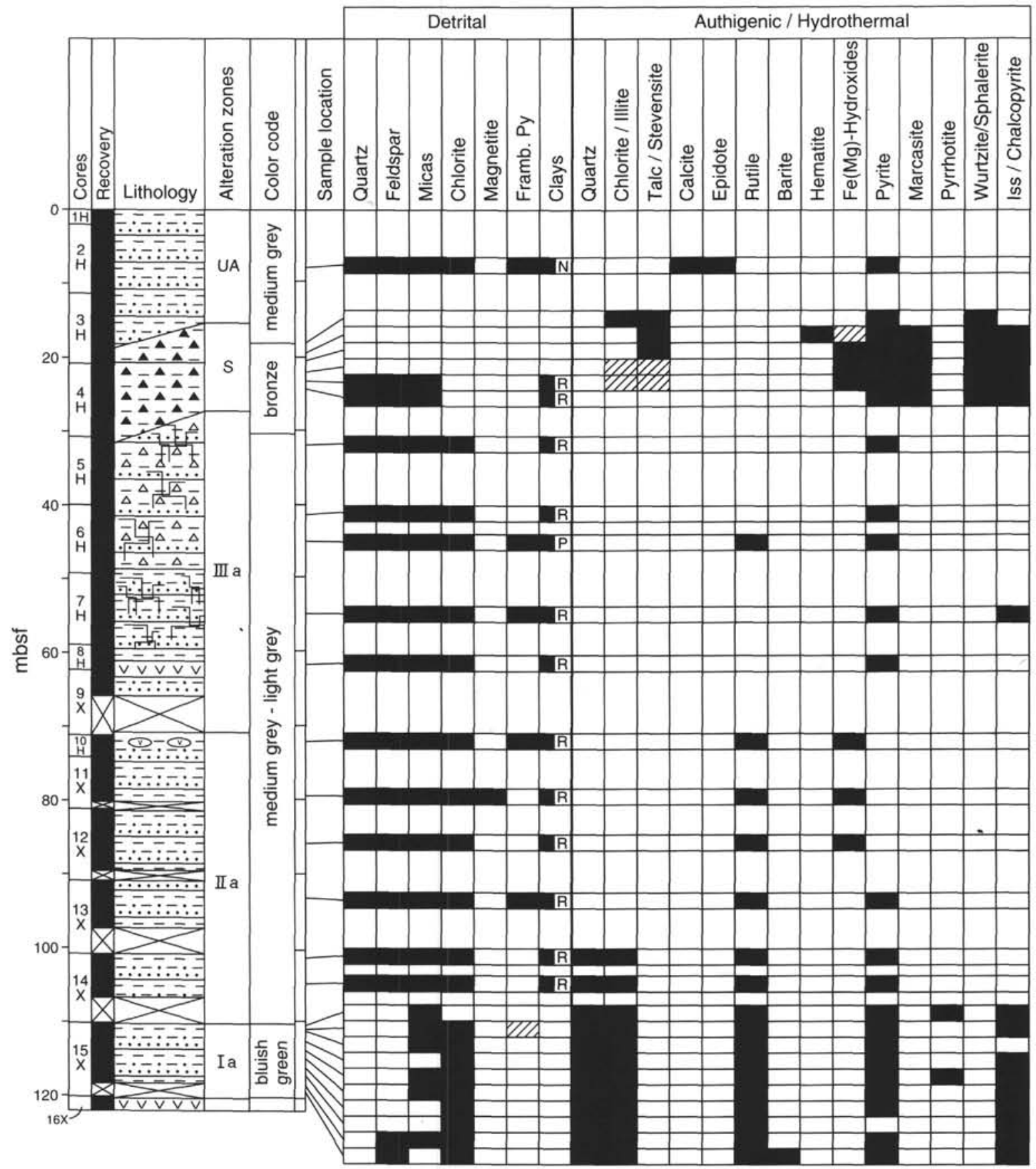

Figure 4. Stratigraphic section of Hole $856 \mathrm{~B}$ showing the general sedimentology, alteration zones, and detrital, authigenic, and hydrothermal minerals based on thin-section descriptions, $\mathrm{UA}=$ unaltered sediment, $\mathrm{S}=$ sulfide. Letter designates clay recrystallization: $\mathrm{N}=$ non; $\mathrm{P}=$ partial; $\mathrm{R}=$ recrystallized. $\mathrm{Black}=$ present; striped $=$ uncertain identification. Lithology symbols as in Fig. 3.

grey to olive grey between 0 and 20 mbsf, olive grey to medium grey between 20 and $65 \mathrm{mbsf}$, and medium dark to light grey below 65 mbsf. Hemipelagic sediment is commonly bioturbated between 29 and 256 mbsf.

Hole $858 \mathrm{~B}$ penetrated $38.6 \mathrm{~m}$ of highly altered hemipelagic and turbiditic sediment with a thin zone of massive sulfide and anhydrite between 10.7 and 12.3 mbsf (Fig. 6). The uppermost two meters consists of green saponite mud that is interbedded with hemipelagic silty clay (Davis, Mottl, Fisher, et al., 1992). This saponite mud is similar to hydrothermal sediment recovered near vents by shallow piston and gravity cores (Goodfellow and Blaise, 1988; Goodfellow et al., in press; Turner et al., in press). Between 2 and 10.7 mbsf, hemipelagic and turbiditic sediments are unconsolidated to weakly indurated and grey to greenish grey. Sediments become indurated with depth and are brecciated below 24 mbsf.

Hole $858 \mathrm{C}$ intersected $93.6 \mathrm{~m}$ of interbedded hemipelagic and turbiditic sediment (Fig. 7). Sediment induration generally increases with depth except between 5 and 17 mbsf where massive carbonates occur. Sediments range in color from medium to olive grey between 0 and 16 mbsf to light grey below 16 mbsf. Hemipelagic sediment is commonly bioturbated between 49 and $74 \mathrm{mbsf}$, and brecciated and fractured between 17 and $46 \mathrm{mbsf}$.

Holes $858 \mathrm{D}$ and $858 \mathrm{~F}$ form a continuous section of interbedded hemipelagic and turbiditic sediment near the core of the hydrothermal 


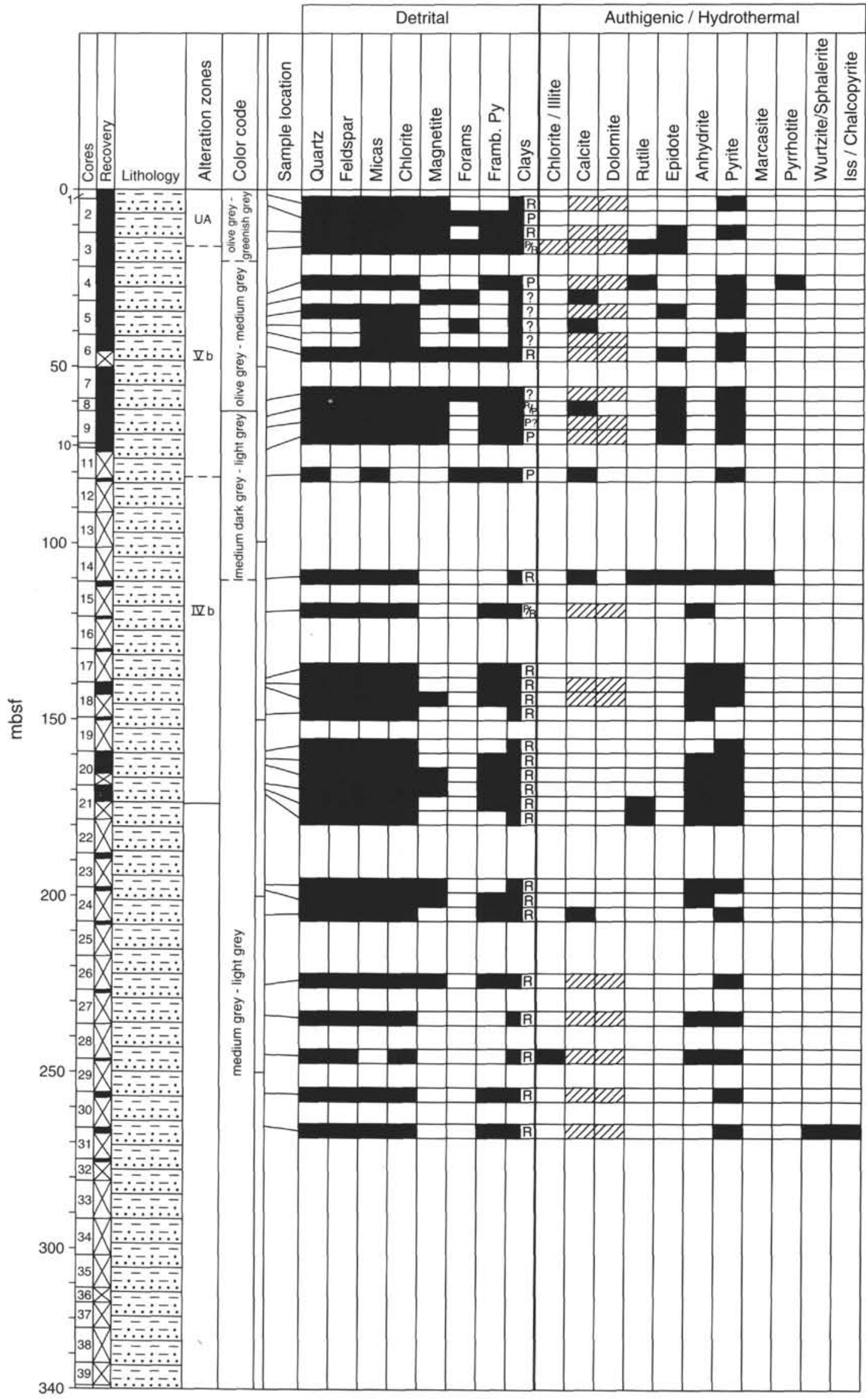

Figure 5. Stratigraphic section of Hole 858A showing the general sedimentology, alteration zones, and detrital, authigenic, and hydrothermal minerals based on thin-section descriptions. $\mathrm{UA}=$ unaltered sediment. Letter designates clay recrystallization: $\mathrm{N}=$ non; $\mathrm{P}=$ partial; $\mathrm{R}=$ recrystallized. Black $=$ present; striped $=$ uncertain identification. Lithology symbols as in Fig. 3. 


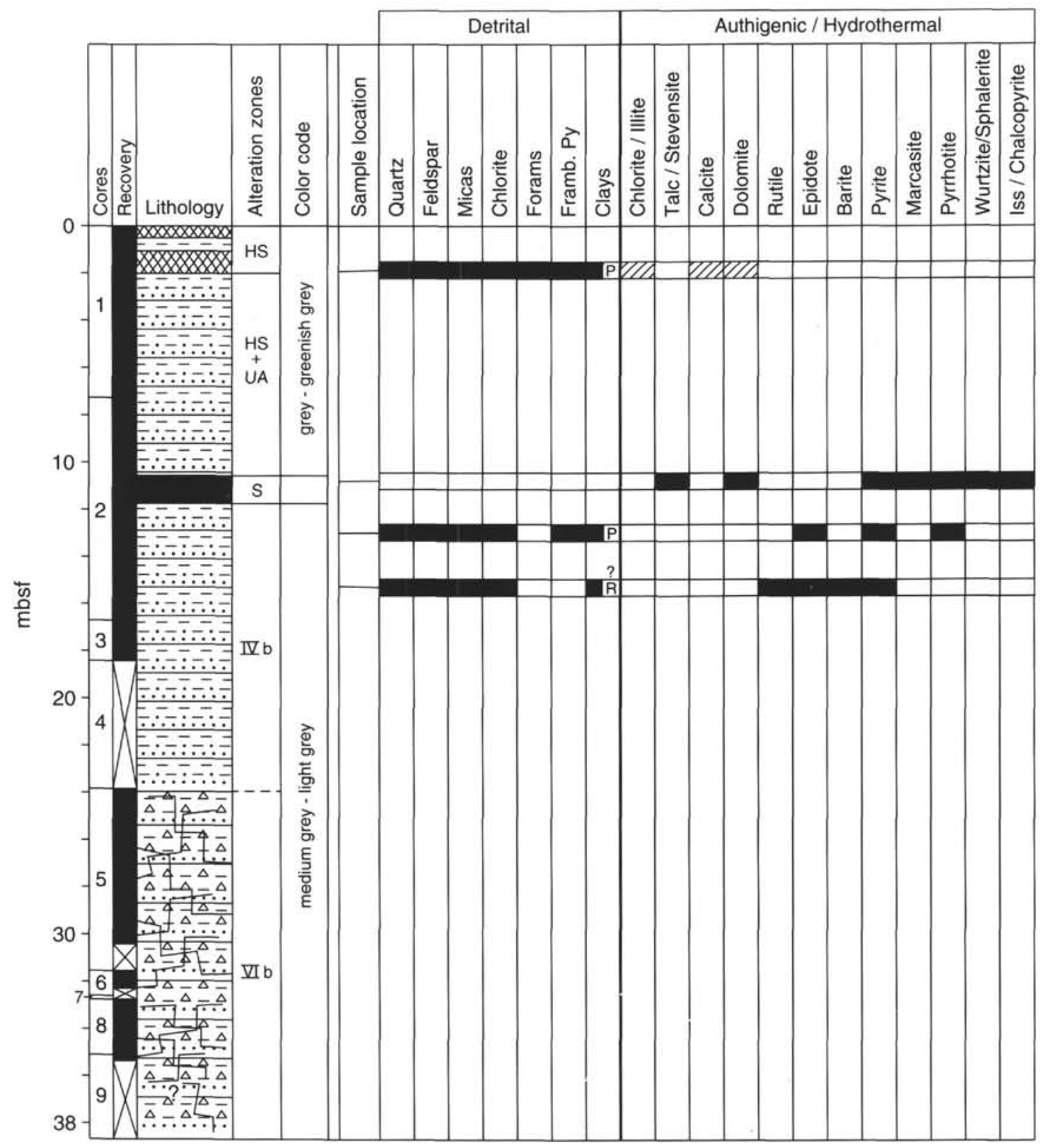

Figure 6. Stratigraphic section of Hole 858B showing the general sedimentology, alteration zones, and detrital, authigenic, and hydrothermal minerals based on thin-section descriptions. $\mathrm{UA}=$ unaltered sediment; $\mathrm{S}=$ sulfide; $\mathrm{HS}=$ hydrothermal sediment. Letter designates clay recrystallization: $\mathrm{N}=$ non; $\mathrm{P}=$ partial; $\mathrm{R}=$ recrystallized. Black = present; striped = uncertain identification. Lithology symbols as in Fig. 3.

upflow zone at Site 858 . Holes $858 \mathrm{D}$ and $858 \mathrm{~F}$ intersected $250 \mathrm{~m}$ of hydrothermally altered sediment and an additional $46.9 \mathrm{~m}$ of underlying mafic flows (Fig. 8). The sediments are unconsolidated to weakly indurated between 0 and 22 mbsf and highly indurated between $22 \mathrm{mbsf}$ and the base of the sedimentary sequence. In the upper part of Holes $858 \mathrm{D}$ and $858 \mathrm{~F}(0-14 \mathrm{mbsf})$, sediments are typically olive grey to greenish grey, whereas the sediments are medium to light grey below 14 mbsf.

\section{Site 857 (Hydrothermal Reaction Zone)}

Site 857 is located $1.6 \mathrm{~km}$ south of Site 858 and $2.2 \mathrm{~km}$ west of Site 856 (Fig. 1) in an area of elevated heat flow (Davis and Villinger, 1992). Holes $857 \mathrm{~A}, 857 \mathrm{C}$, and $857 \mathrm{D}$ were collared within $190 \mathrm{~m}$ of each other and are treated here as a composite section of the sedimentary sequence to a depth of $936 \mathrm{mbsf}$. Interbedded hemipelagic and turbiditic sediments were recovered from the surface to a depth of 480 mbsf (Figs. 9 and 10). Below 480 mbsf, hemipelagic and turbiditic sediments are intercalated with mafic sills (Figs. 10 and 11). Hemipelagic and turbiditic sediments are unconsolidated to weakly indurated and are typically olive grey to greenish grey between 0 and 54 mbsf. Sediments are partly to moderately indurated and olive grey between 54 and $200 \mathrm{mbsf}$, whereas below $200 \mathrm{mbsf}$, they are indurated and the sediment color changes from medium dark grey to light grey with depth. Bioturbation is common between 26 and $342 \mathrm{mbsf}$.

\section{Site 855}

Site 855 is in an area of low heat flow near the base of a large fault (115 $\mathrm{m}$ throw) at the eastern margin of Middle Valley (Davis, Mottl, Fisher, et al., 1992; Davis and Villinger, 1992) (Fig. 1). Sediment thicknesses near this site are highly variable but generally $<100 \mathrm{~m}$ 


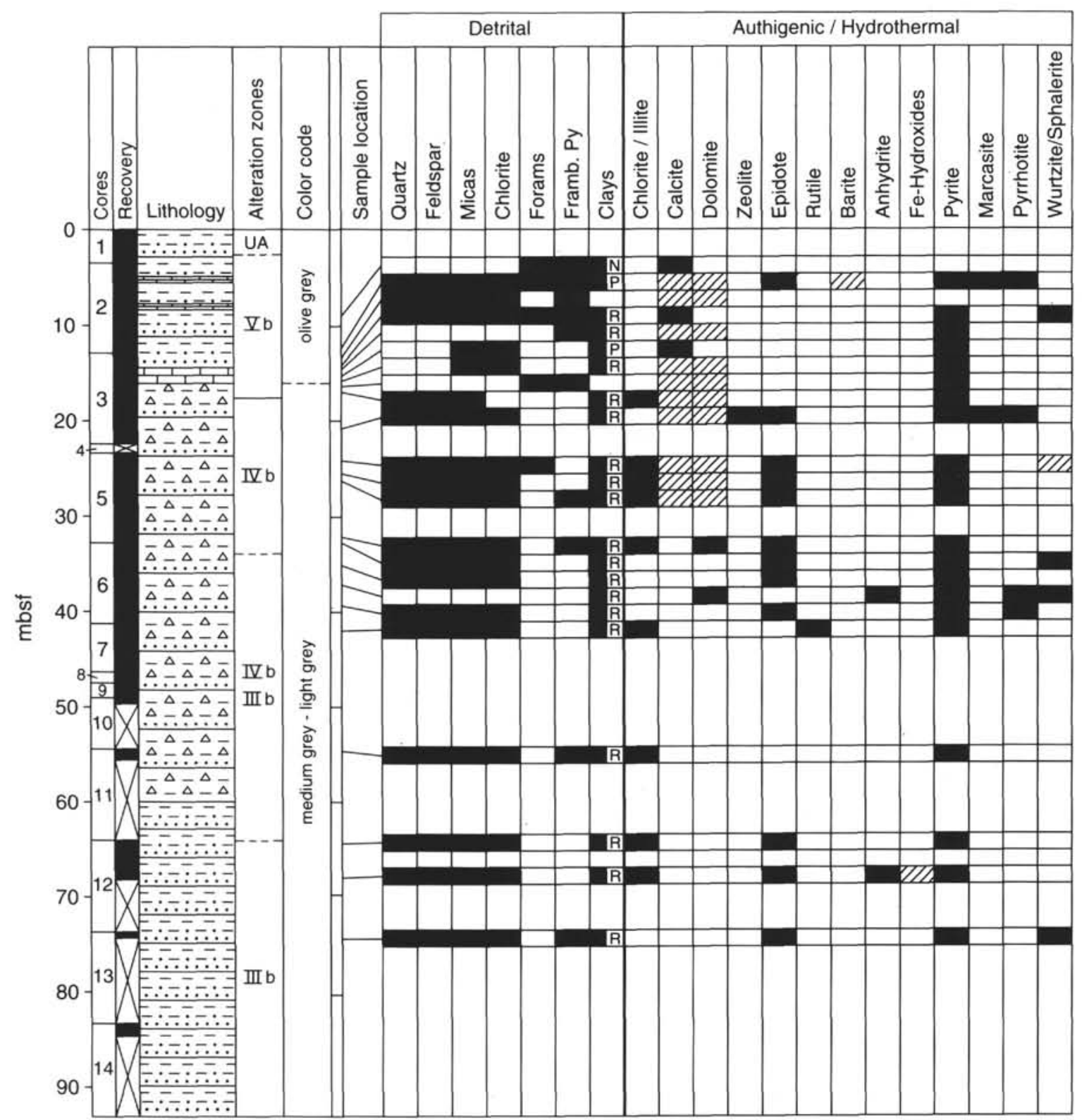

Figure 7. Stratigraphic section of Hole $858 \mathrm{C}$ showing the general sedimentology, alteration zones, and detrital, authigenic, and hydrothermal minerals based on thin-section descriptions. $\mathrm{UA}=$ unaltered sediment. Letter designates clay recrystallization: $\mathrm{N}=$ non; $\mathrm{P}=$ partial; $\mathrm{R}=$ recrystallized. Black $=$ present; striped $=$ uncertain identification. Lithology symbols as in Fig. 3.

(Davis, Mottl, Fisher, et al., 1992). A total of four holes were drilled at Site 855 , at distances between 40 and $125 \mathrm{~m}$ from the base of the fault scarp. All three holes sampled at Site 855 are dominated by relatively unaltered, unconsolidated to weakly indurated, interbedded olive grey hemipelagic silty clays and medium to dark grey turbiditic silt and sand. Turbiditic beds display sharp and commonly scoured bases and fine upward into hemipelagic sediment. Hole $855 \mathrm{C}$, the deepest hole $(111 \mathrm{~m})$ with the highest $(54 \%)$ core recovery, penetrated 28 turbidite sequences ranging in thickness from 13 to $131 \mathrm{~cm}$ (Davis, Mottl, Fisher, et al., 1992). All holes were terminated in mafic flows and the sediment overlying these flows shows no evidence of thermal metamorphism (Davis, Mottl, Fisher, et al., 1992).

\section{SAMPLING AND ANALYTICAL METHODS}

A total of 612 sediment and massive sulfide core samples were collected during Leg 139. Sampling procedures are described in
Davis, Mottl, Fisher, et al. (1992). All samples were described macroscopically and analyzed for major and trace elements (Goodfellow and Peter, this volume); 246 polished thin sections were prepared from selected samples and examined by transmitted- and reflectedlight microscopy. Samples of unconsolidated or friable sediment were vacuum-impregnated with epoxy prior to thin-section preparation. $\mathrm{X}$-ray diffraction (XRD) analyses were conducted on 80 powdered bulk sediment samples and interstitial silicate and carbonate minerals drilled from massive sulfides (Holes $856 \mathrm{G}$ and $856 \mathrm{H}$ ). XRD analyses were performed on a Phillips PW1710 X-ray diffractometer at a scanning rate of $6^{\circ} 2 \mathrm{q}$ per minute for the range $3^{\circ}-63^{\circ} 2 \mathrm{q}$ using $\mathrm{Cu} \mathrm{Ka}$ radiation at $50 \mathrm{kV}$ and $30 \mathrm{~mA}$.

Silicate, sulfate, carbonate and sulfide minerals in 89 sections were analyzed by a Cameca-Camebax Microbeam electron microprobe utilizing online PAP matrix correction reduction. Due to their fine grain size, clay minerals were analyzed semiquantitatively. Operating conditions used for silicates, carbonates, and sulfates were 15 


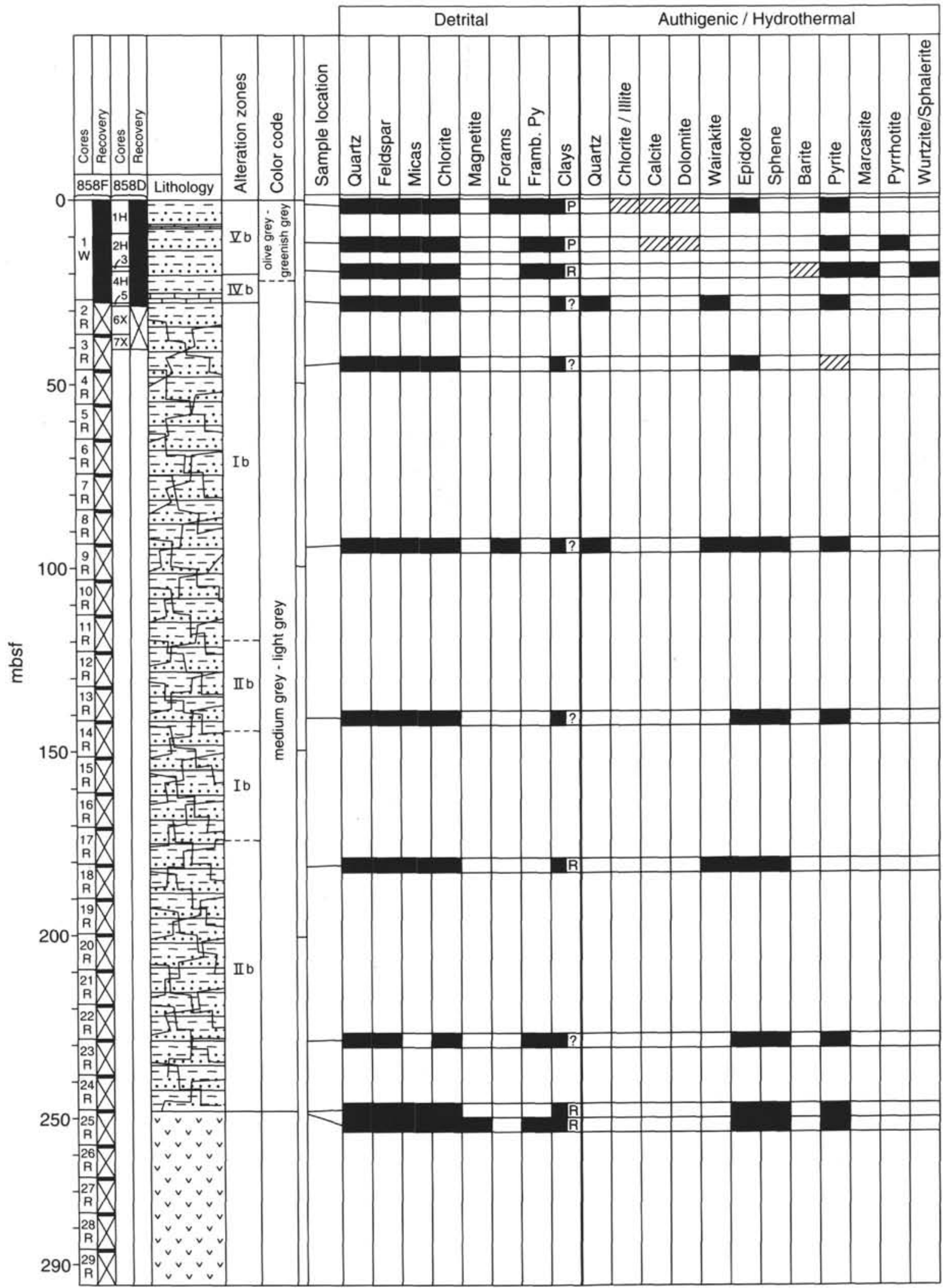

Figure 8. Stratigraphic section of Holes $858 \mathrm{D}$ and $858 \mathrm{~F}$ showing the general sedimentology, alteration zones, and detrital, authigenic, and hydrothermal minerals based on thin-section descriptions. Letter designates clay recrystallization: $\mathrm{N}=$ non; $\mathrm{P}=$ partial; $\mathrm{R}=$ recrystallized. Black $=$ present; striped $=$ uncertain identification. Lithology symbols as in Fig. 3. 


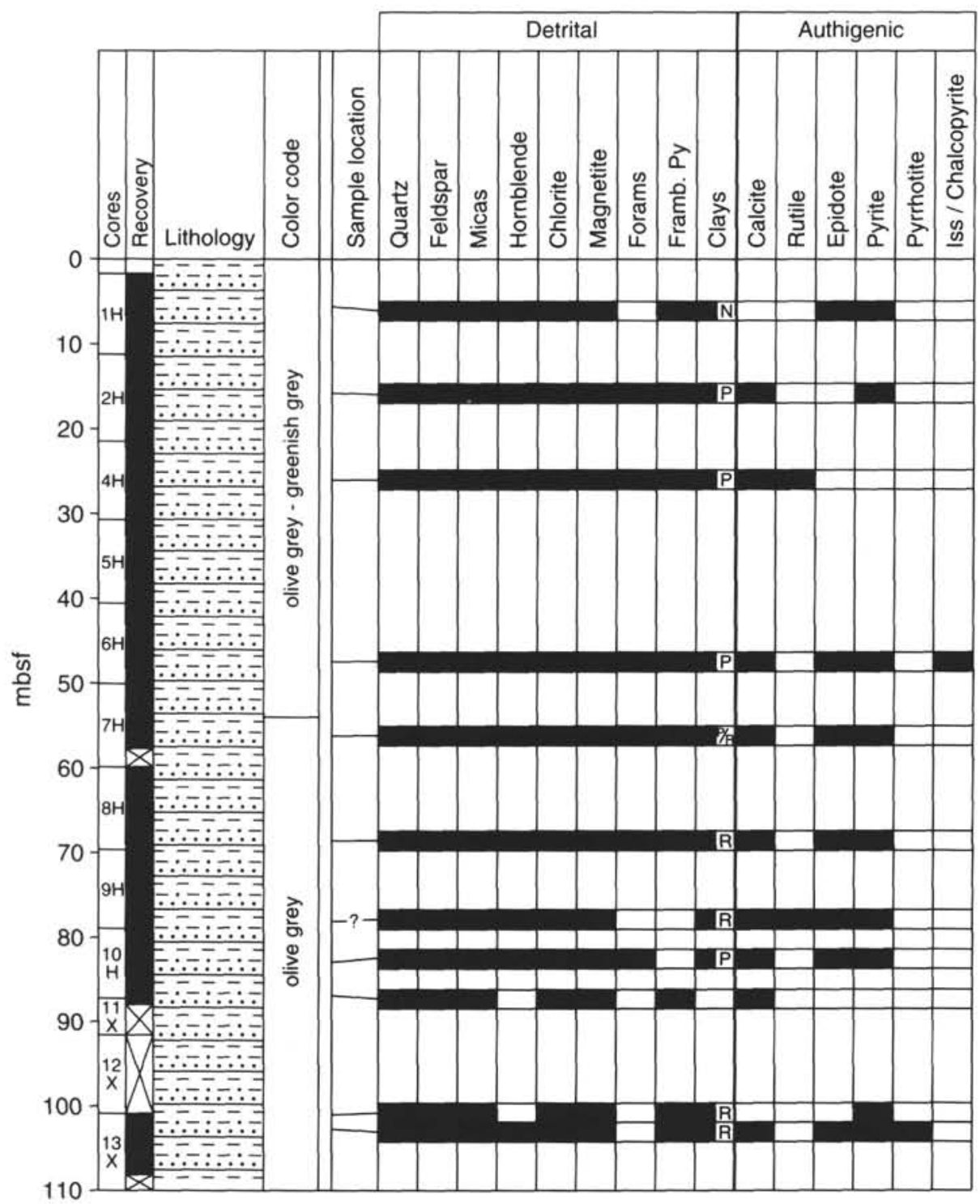

Figure 9. Stratigraphic section of Hole 857A showing the general sedimentology and mineralogy based on thin-section descriptions. Letter designates clay recrystallization: $\mathrm{N}=$ non; $\mathrm{P}=$ partial; $\mathrm{R}=$ recrystallized. $\mathrm{Black}=$ present; striped = uncertain identification. Lithology symbols as in Fig. 3 .

$\mathrm{kV}$ electron acceleration potential and 1-2 $\mu \mathrm{m}$ beam diameter. For feldspars and wairakite, counting times were 40 seconds for all elements and the sample current was $10 \mathrm{nA}$. Mineral standards used were sodium chloride $(\mathrm{Na})$, potassium bromide $(\mathrm{K})$, quartz $(\mathrm{Si})$, magnetite $(\mathrm{Fe})$, corundum $(\mathrm{Al})$, wollastonite $(\mathrm{Ca})$, and sanidine $(\mathrm{Ba})$. For all other silicates, counting times were 20 seconds at $10 \mathrm{nA}$ sample current for $\mathrm{Na}, \mathrm{K}, \mathrm{Mg}$, and $\mathrm{Fe}$ and 10 seconds at $30 \mathrm{nA}$ for $\mathrm{Al}, \mathrm{Si}, \mathrm{Ca}$, $\mathrm{Ti}, \mathrm{Mn}, \mathrm{Cr}$, and $\mathrm{Zn}$. The mineral standards used were labradorite $(\mathrm{Na}$, $\mathrm{Al}, \mathrm{Si})$, orthoclase $(\mathrm{K})$, diopside $(\mathrm{Mg}, \mathrm{Ca})$, fayalite $(\mathrm{Fe})$, rutile $(\mathrm{Ti})$, rhodochrosite $(\mathrm{Mn}, \mathrm{Zn})$, and chromite $(\mathrm{Cr})$. For sulfate and carbonate minerals, 10 seconds counting time was used for all elements at $10 \mathrm{nA}$ $(\mathrm{Ca}, \mathrm{Mg}, \mathrm{Ba}, \mathrm{Fe}$, and $\mathrm{Zn})$ and $30 \mathrm{nA}(\mathrm{Sr}, \mathrm{Mn}, \mathrm{S}$, and $\mathrm{Si}$ ) sample current. Mineral standards used were dolomite $(\mathrm{Ca}, \mathrm{Mg})$, barite $(\mathrm{Ba}$, $\mathrm{S})$, magnetite ( $\mathrm{Fe})$, smithsonite $(\mathrm{Zn})$, strontianite $(\mathrm{Sr})$, rhodochrosite $(\mathrm{Mn})$, and quartz (Si).

Thirty polished thin sections and grain mounts were analyzed using a Cambridge S-200 scanning electron microscope (SEM) fitted with an energy dispersive X-ray (EDS) detection system (Link Analytical AN10 analyzer) to allow semiquantitative determinations of the clay minerals. The SEM was run at $20 \mathrm{kV}$ at working distances of 15 to $30 \mathrm{~mm}$, in both secondary and backscatter modes.

\section{MINERALOGY}

\section{Unaltered Sediment}

Unaltered sediments were recovered from Site 855, the uppermost $17 \mathrm{~m}$ of Holes $856 \mathrm{~A}$ and $856 \mathrm{~B}$, the uppermost $10 \mathrm{~m}$ of Hole $858 \mathrm{~A}$, and the uppermost $70 \mathrm{~m}$ of Hole $857 \mathrm{~A}$. Unaltered sediments are unconsolidated to weakly indurated, interbedded, olive-grey hemipelagic silty clays and medium- to dark-grey turbiditic silt and sand. The petrographic and XRD mineralogy of unaltered sediments are consistent with previous studies from Middle Valley and show that hemipelagic sediment consists, in order of decreasing abundance, of quartz, plagioclase, amphibole, mica, chlorite, and epidote with a clay fraction composed of smectite $>$ chlorite $>$ illite $>$ irregular mixed layer clays (Tables 1 and 2; Goodfellow and Blaise, 1988; Al-Aasm and Blaise, 1991; Goodfellow et al., in press; Turner et al., in press). Important minor and trace minerals include calcite, pyrite, and magnetite (Table 1).

Detrital quartz is abundant (up to 40 volume percent [vol\%]) and consists of equant, anhedral to subhedral grains devoid of fluid inclusions. Quartz is highly variable in size and ranges from $<75 \mu \mathrm{m}$ in silty clay to $>125 \mu \mathrm{m}$ in turbiditic sandy silt. Detrital feldspar occurs 
Table 1. Summary of downhole mineralogy for Hole 855C.

\begin{tabular}{|c|c|c|c|c|c|c|c|c|c|c|c|c|c|c|}
\hline $\begin{array}{l}\text { Core, section, } \\
\text { interval }(\mathrm{cm})\end{array}$ & $\begin{array}{l}\text { Grain } \\
\text { size }\end{array}$ & $\begin{array}{l}\text { Depth } \\
\text { (mbsf) }\end{array}$ & $\mathrm{Qz}$ & Fs & Clay & Micas & $\mathrm{Ch}$ & $\mathrm{Hb}$ & Ep & Mag & $M-f$ & F-py & Carb & Py \\
\hline \multicolumn{15}{|l|}{$139-855 \mathrm{C}-$} \\
\hline $1 \mathrm{R}-1,57-61$ & Silty clay & 0.57 & $x x x$ & $x x$ & $x x x x x$ & $x x x$ & $x x$ & $\mathrm{x}$ & & $\mathrm{x}$ & $\mathrm{xx}$ & $\mathrm{x}$ & & $\mathrm{x}$ \\
\hline $2 \mathrm{R}-1,53-57$ & Silty clay & 9.23 & & $x x x$ & $x x$ & $x x x x x$ & $\mathrm{xxx}$ & $x x$ & $x$ & & $\mathrm{x}$ & $\mathrm{xx}$ & $\mathrm{x}$ & \\
\hline $3 \mathrm{R}-1,45-47$ & Silty clay & 18.15 & $\mathrm{xxx}$ & $x x$ & $\operatorname{xxxxx}$ & $x x$ & $x x$ & $x x$ & & $\mathrm{x}$ & & & $x$ & $x$ \\
\hline $7 R-4,80-84$ & Silty clay & 61.40 & $\mathrm{xxxx}$ & $x x x$ & $x x x x x$ & $x x x x$ & $x x$ & $x x x$ & & $\mathrm{x}$ & $\mathrm{xxx}$ & $\mathrm{x}$ & $x x x$ & \\
\hline $10 \mathrm{R}-1,130-134$ & Silty clay & 86.20 & $\mathrm{xxx}$ & $x x$ & $x x x x x$ & $\mathrm{xx}$ & $\mathrm{xx}$ & $\mathrm{xx}$ & & $x$ & & $\mathrm{x}$ & & $\mathrm{x}$ \\
\hline $11 R-1,115-119$ & Finegrained sand & 95.75 & $x \times x x$ & $x x x x$ & $x \times x x$ & $x$ & $x x$ & $x x x$ & $x x x$ & $x$ & & & $x$ & \\
\hline
\end{tabular}

Notes: $x x x x x=$ dominant $(>50 \%) ; x x x=$ major $(11-50 \%) ; x x x=\operatorname{minor}(3-10 \%) ; x x=$ trace $(1-2 \%) ; x=$ rare $(<1 \%) ; Q z=q u a r t z ; F s=f e l d s p a r ; \mathrm{Hb}=$ hornblende; Ch = chlorite; Carb = carbonate; $\mathrm{Ep}=$ epidote; $\mathrm{Mag}=$ magnetite; $\mathrm{M}-\mathrm{f}=$ microfossils; $\mathrm{F}$-py = framboidal pyrite; $\mathrm{Py}=$ pyrite.

as subequant, subhedral to anhedral, twinned, unaltered grains, although K-feldspar commonly exhibits incipient alteration to chlorite and sericite. The most abundant feldspar is plagioclase (An 1 to An 58) with lesser K-feldspar (Table 3; Fig. 12A). Detrital mica up to 12 $\mu \mathrm{m}$ in length forms up to several vol\%. The dominant detrital mica is muscovite, although rare biotite also occurs in some samples. Chlorite occurs as detrital crystals up to $100 \mu \mathrm{m}$ in length, and also forms a significant component of the clay fraction. Hornblende occurs as equant, subhedral to anhedral grains up to $100 \mu \mathrm{m}$ in diameter and forms up to 5 vol\% (Table 1). Ragged to anhedral detrital Fe-rich, Al-poor epidote (Table 4; Fig. 13) occurs preferentially in coarsergrained turbidites. Framboidal and anhedral pyrite occur in trace amounts (Table 1) commonly infilling burrows and, less commonly, the centers of foraminifers. Disseminated anhedral to subhedral magnetite occurs in trace amounts throughout Hole 855C (Table 1).

Clay minerals consist of chlorite, illite, and smectite and are typically weakly recrystallized above $10 \mathrm{mbsf}$. They become increasingly recrystallized and fibrous and display common extinction angles at depths greater than 10 mbsf. In Sample 139-855C-11R-1, $115-119 \mathrm{~cm}$ (96 mbsf) in Hole 855C, rare small patches of authigenic clay are present.

Minor calcite (Table 1) occurs as foraminifers and anhedral to subhedral calcite cement in turbiditic sand and silt throughout Hole $855 \mathrm{C}$. Foraminifers are variably infilled with calcite to a depth of 62 mbsf in Hole $855 \mathrm{C}$, below which they are absent.

\section{Hydrothermal Alteration}

\section{Site 856 (Bent Hill)}

BH (Site 856) has been subdivided on the basis of mineralogy, mineral chemistry, and bulk chemistry (Goodfellow and Peter, this volume) into several alteration zones that increase in temperature toward the center of hydrothermal fluid discharge. These zones are discussed below from the outer margins to the core of fluid upflow, are summarized in Table 5, and are shown in Figure 14. The downhole variation of hydrothermal minerals about the $\mathrm{BH}$ massive sulfide mound is given in Figures 3 and 4.

\section{Zone IVa}

This zone consists of calcite-illite-pyrite and occurs in Hole 856A between 17 and $86 \mathrm{mbsf}$ (Fig. 3). It is not present in Hole 856B due to mass wasting. Sediments in this zone are weakly to moderately indurated.

Detrital quartz below $45 \mathrm{mbsf}$ in Hole $856 \mathrm{~A}$ commonly contains abundant fluid inclusions and more irregular boundaries than in unaltered sediment, suggesting partial dissolution and recrystallization. Detrital plagioclase is albitized $(\mathrm{An} \leq 17)$ at depths $>44 \mathrm{mbsf}$ in Hole 856A (Table 3; Fig. 12A). K-feldspar below $17 \mathrm{mbsf}$ is partially altered to chlorite and sericite. Pyrite occurs finely disseminated throughout hemipelagic sediment and interstitially within turbiditic silt and sand and is associated with burrows and carbonate concretions, commonly as central accumulations or bands in the concretions. Pyrite also replaces magnetite, which is present in trace amounts throughout this zone in Hole 856A. Pyrite forms euhedral to anhedral crystals and framboidal aggregates that range up to $2 \mathrm{vol} \%$. The grain size of pyrite increases with depth (up to $500 \mu \mathrm{m}$ at $60 \mathrm{mbsf}$ ).

Clay minerals are increasingly recrystallized with depth as is evidenced by common extinction in thin section and an increase in grain size. XRD data suggest that the clay fraction consists predominantly of chlorite and illite (Davis, Mottl, Fisher, et al., 1992). In turbiditic silt and sand, clay minerals occur interstitial to detrital quartz and feldspar.

Carbonate occurs mainly as calcite concretions and less commonly as disseminated crystals in the interstices of turbiditic silt and sand. Concretions occur between 17 and $86 \mathrm{mbsf}$ (Table 6) in several forms including laminated (e.g., Sample 139-856A-6H-4, 69-77 cm) and concentrically zoned with a solid core and diffuse margins. Concretions range up to $50 \mathrm{~cm}$ in length and differential compaction of sediment around some concretions indicates formation before diagenesis whereas laminated concretions probably formed after sediment diagenesis (Davis, Mottl, Fisher, et al., 1992). Concretions from deeper in the hole (69-76 mbsf; Sample 139-856A-9H-1, 44-47 cm and $139-856 \mathrm{~A}-9 \mathrm{H}-5,41-42 \mathrm{~cm}$ ) consist of irregular patches of anhedral to subhedral calcite up to $0.5 \mathrm{~mm}$ in diameter.

\section{Zone IIIa}

This zone consists of anhydrite-illite-pyrite and occurs between 60 mbsf and the bottom of Hole 856A (Fig. 3) and between 30 and 70 mbsf in Hole 856B (Fig. 4). Sediments in this zone are moderately indurated to indurated and commonly brecciated.

Detrital quartz commonly hosts two-phase fluid inclusions at depths greater than $55 \mathrm{mbsf}$ in Hole $856 \mathrm{~B}$, indicating partial recrystallization. Below 22 mbsf in Hole 856B, K-feldspar is increasingly altered to sericite and chlorite. K-feldspar in Sample 139-856B-6H-4, 124-126 cm ranges in composition between Or 81 and Or 97 (Table 3; Fig. 12A). Detrital plagioclase is replaced by albite (An 8.5). Although anhydrite was not observed in hand samples or thin sections from Holes $856 \mathrm{~A}$ and $856 \mathrm{~B}$, the presence of anhydrite molds and associated elevated $\mathrm{SO}_{4}^{2-}$ contents in pore waters from both holes indicates that anhydrite was present but was dissolved by later fluids (Davis, Mottl, Fisher, et al., 1992). The detection of anhydrite in Core $139-856 \mathrm{~A}-8 \mathrm{H}$ by XRD and in Sample 139-856B-3H-6, 34-36 cm by SEM is further evidence of the occurrence of hydrothermal anhydrite (Davis, Mottl, Fisher, et al., 1992). Pyrite in Hole 856B occurs predominantly as isolated crystals and crystal clusters and more rarely as framboidal pyrite that infills burrows. Shipboard logging noted that pyrite clots and disseminations are more abundant along fluid channelways between breccia clasts between 28 and 66 mbsf (Davis, Mottl, Fisher, et al., 1992). Pyrite is typically subhedral to anhedral and is rarely euhedral. Below 55 mbsf, chalcopyrite and rarely pyrrhotite were observed with pyrite. Magnetite is completely replaced by pyrite below $97 \mathrm{mbsf}$ in Hole $856 \mathrm{~A}$ (Table 6).

Clay minerals in Hole 856B consist predominantly of illite and Mg-chlorite (Tables 7 and 8; Figs. 15A-C and 16), are recrystallized and increase in grain size with depth. The chlorite and illite clays are amorphous to fine-grained $(<10 \mu \mathrm{m})$ and fibrous between 55 and 95 


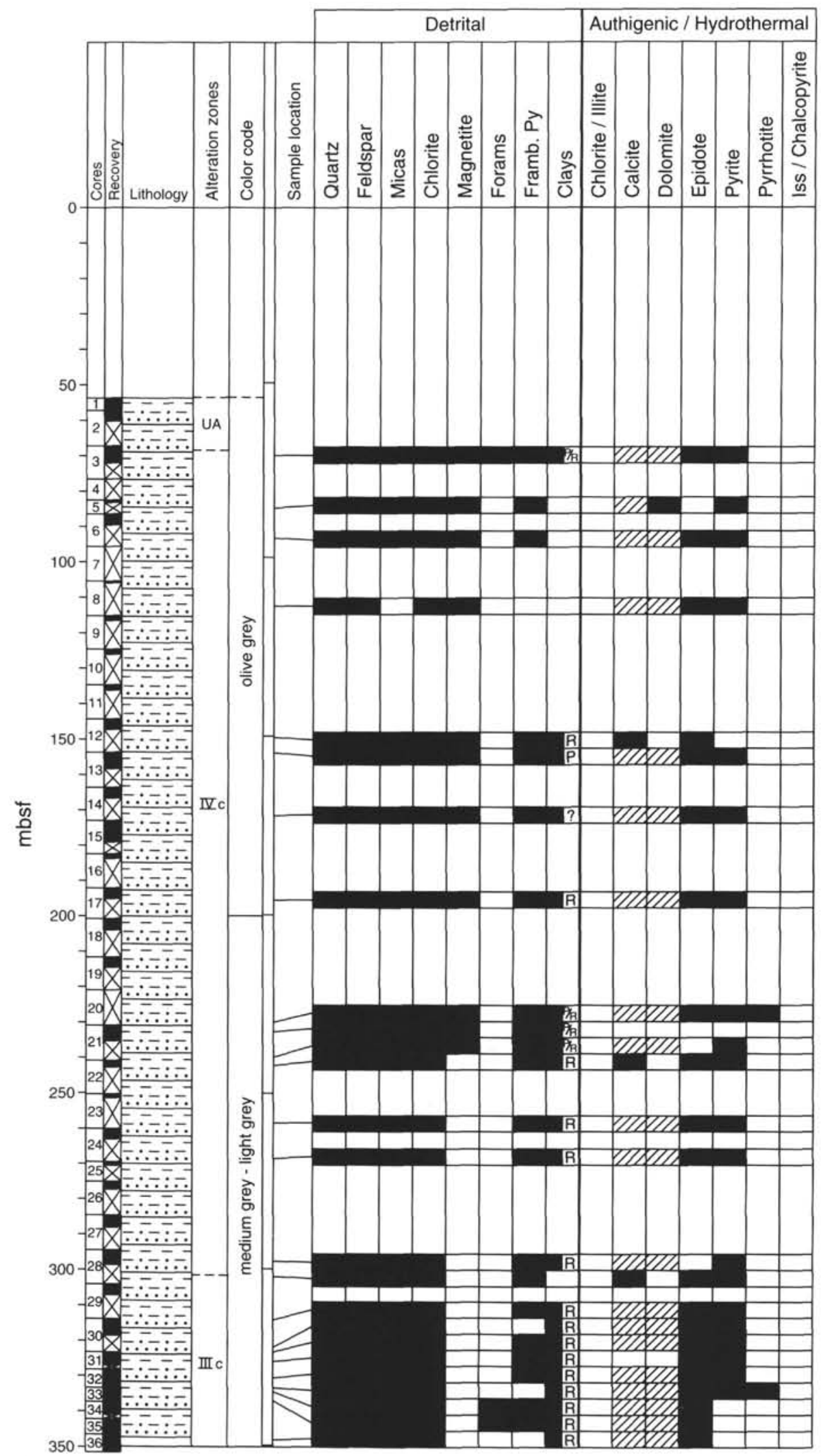

Figure 10. Stratigraphic section of Hole $857 \mathrm{C}$ showing the general sedimentology, alteration zones, and detrital, authigenic, and hydrothermal minerals based on thin-section descriptions. $\mathrm{UA}=$ unaltered sediment. Letter designates clay recrystallization; $\mathrm{N}=$ non; $\mathrm{P}=$ partial; $\mathrm{R}=$ recrystallized. Black $=$ present; striped $=$ uncertain identification. Lithology symbols as in Fig. 3. 


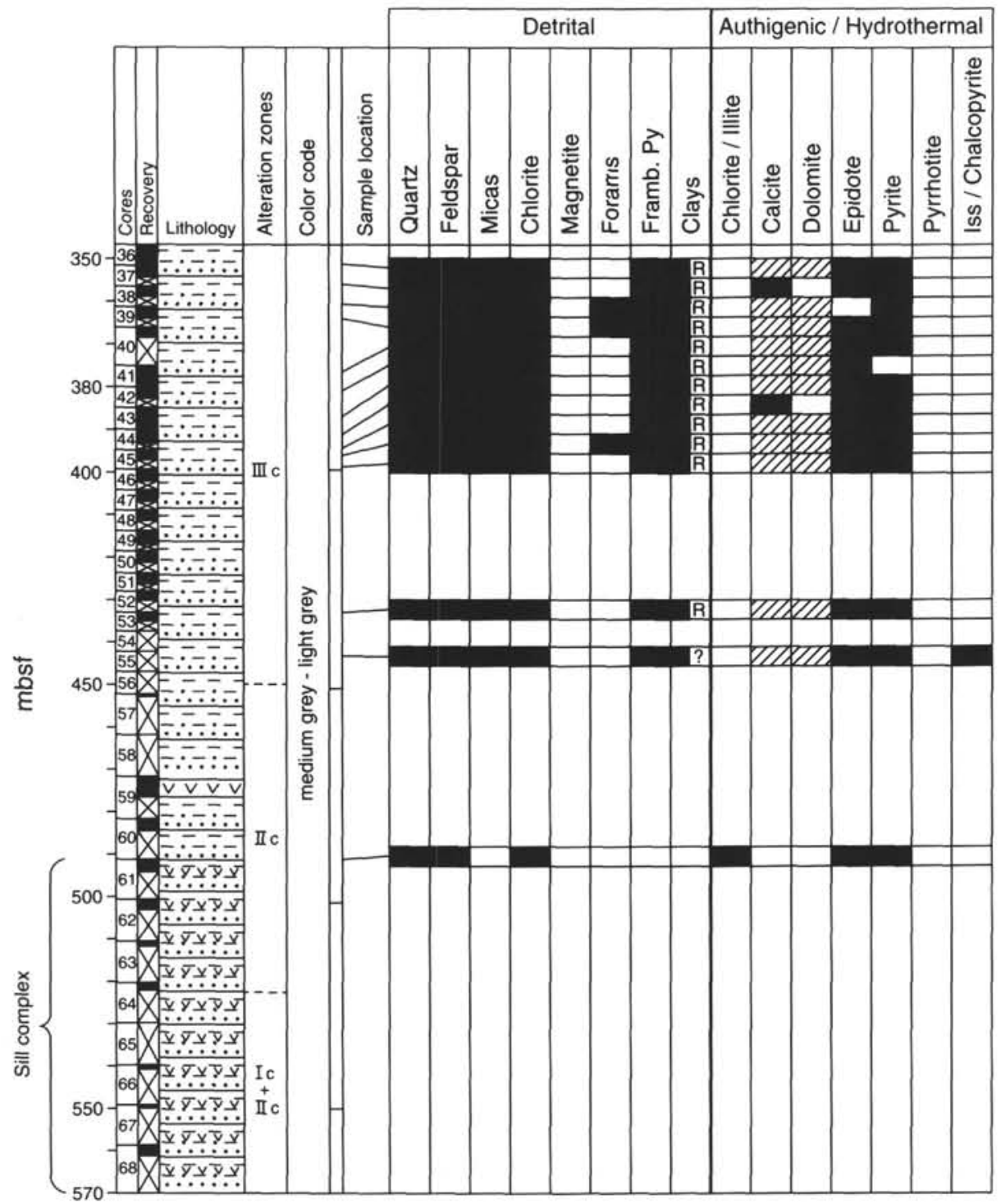

Figure 10 (continued).

mbsf and coarser-grained below 95 mbsf (10-25 $\mu \mathrm{m}$; Pl. 1, Figs. 1-6). Clays are more recrystallized in the matrix between breccia clasts.

\section{Zone IIa}

This zone, which consists of albite-chlorite-pyrite, occurs between 70 and 110 mbsf in Hole 856B (Fig. 4) and is not present in Hole $856 \mathrm{~A}$. Detrital quartz below $75 \mathrm{mbsf}$ has ragged to diffuse boundaries due to overgrowths and recrystallization and is typically anhedral although it rarely exhibits euhedral terminations (PI. 1, Fig. 1). As in Zone IIIa, plagioclase is altered to albite (Fig. 12A) and $\mathrm{K}$-feldspar is altered to sericite and chlorite. Rutile is an important accessory phase below 72 mbsf in Hole 856B (Table 6; Fig. 4) and commonly occurs in aggregates of $2-5$ crystals up to $50-75 \mu \mathrm{m}$ in diameter. Rutile's euhedral to anhedral morphology and absence from unaltered sediments indicate that rutile formed authigenically. Pyrite in this zone occurs as anhedral to euhedral isolated crystals and crystal clusters, and is very rarely framboidal.

Moderately indurated silty clay below 80 mbsf in Hole $856 \mathrm{~B}$ (Cores 139-856B-12X and -13X) consists of subparallel, aligned, amorphous to fibrous chlorite + illite/muscovite. The clay minerals are up to $25 \mu \mathrm{m}$ in length and are coarser-grained than in Zone IIIa.
Chlorite and illite/muscovite are more Mg-rich in Zone IIa than Zone Ia (Figs. 15A,B and 16).

\section{Zone Ia-1}

This zone occurs in Hole 856B between 110 and 117.5 mbsf (Fig. 4) and is characterized by the high-temperature alteration assemblage quartz-(Fe)chlorite-muscovite-rutile-chalcopyrite-pyrrhotite. Authigenic quartz is typically anhedral to subhedral with ragged boundaries, although quartz separates prepared for isotope analyses commonly exhibit subhedral to euhedral morphologies. Detrital plagioclase and $\mathrm{K}$-feldspar were not observed in this zone and have presumably been destroyed during hydrothermal alteration of sediments to chlorite and illite/muscovite. Pyrite and chalcopyrite form large ( $>2 \mathrm{~mm}$ ) crystal clusters and occur disseminated throughout this zone. Sulfide and sulfate minerals (chalcopyrite-sphalerite-pyrrhotite, chalcopyritepyrrhotite, pyrite-chalcopyrite, barite-chalcopyrite, barite, chalcopyrite, and sphalerite) form bedding parallel to high-angle veins in Core 139-856B-15X near the bottom of the hole.

The clay minerals consist of crystalline chlorite and illite/muscovite. Variable $\mathrm{Fe}$ and $\mathrm{Mg}$ contents in illite/muscovite (Table 8; Fig. $15 \mathrm{C}$ ) indicate either a muscovite/chlorite mixed layer assemblage or 


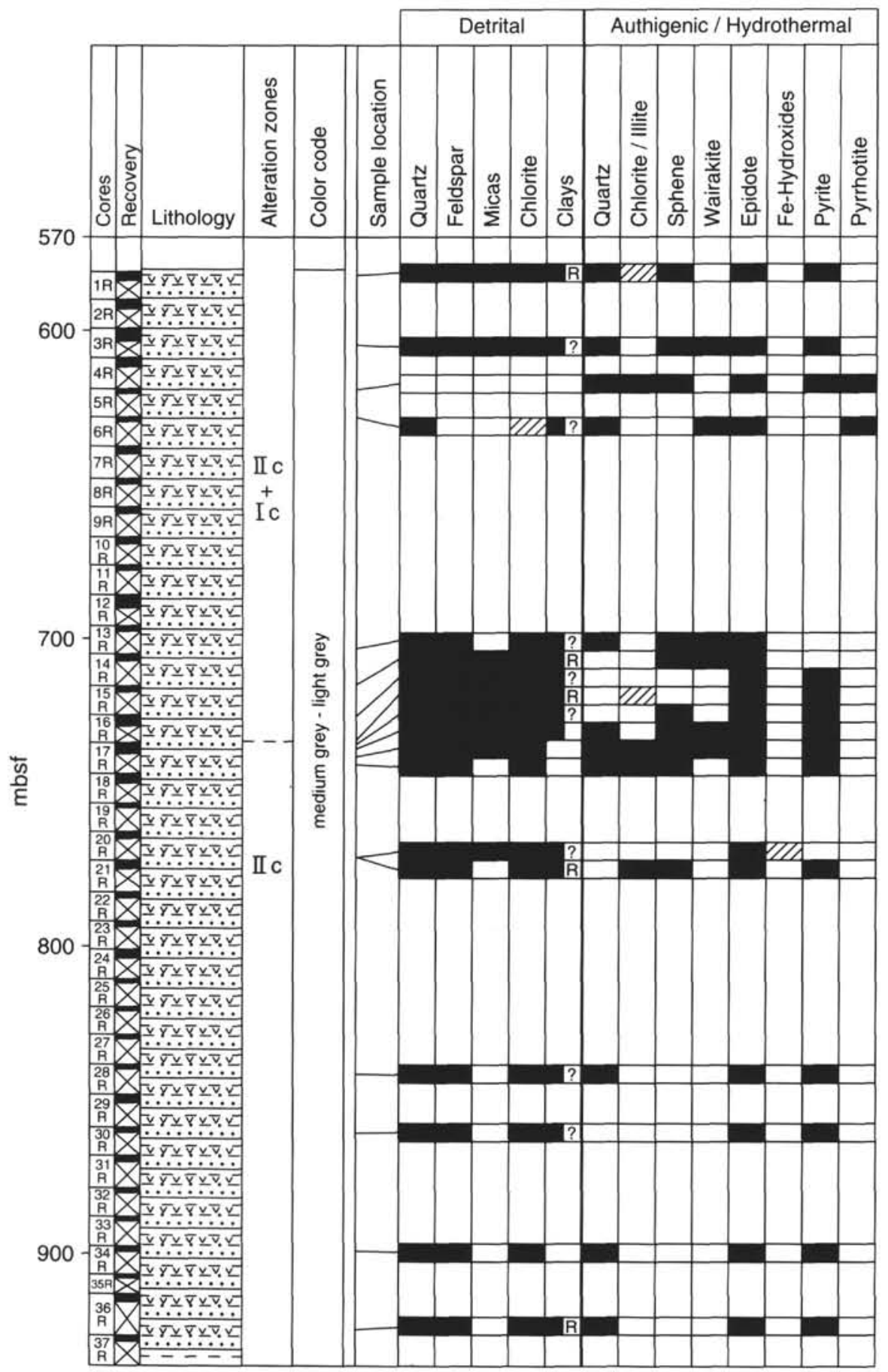

Figure 11. Stratigraphic section of Hole 857D showing the general sedimentology, alteration zones, and detrital, authigenic, and hydrothermal minerals based on thin-section descriptions. Letter designates clay recrystallization: $\mathrm{N}=$ non; $\mathrm{P}=$ partial; $\mathrm{R}=$ recrystallized. Black $=$ present; striped $=$ uncertain identification. Lithology symbols as in Fig. 3.

that the microprobe measured a mixture of muscovite and chlorite. The latter is most likely given the clear separation of chlorite and muscovite in coarse-grained samples in Core 139-856B-15X (PI. 1, Figs. 1-6). Phyllosilicates from Zones IIIa, IIa, and Ia plotted on a ternary Fe-Al$\mathrm{Mg}$ diagram range in composition from a muscovite end-member (at the Al-apex) to chlorite (Fig. 15A-C). The chlorite in Core 139-856B$15 \mathrm{X}$ is typically Fe-rich and generally more Fe-rich than chlorite from Zones IIIa and IIa in Holes 856B and 856A, and core from Sites 857 and 858 (Table 7; Figs. 15 and 16). Chlorite grains in Core 139-856B$15 \mathrm{X}$ are rarely zoned from $\mathrm{Mg}$-rich cores to Fe-rich rims (Pl. 1, Fig. 1).

\section{Zone Ia-2}

This is a narrow subzone of Zone Ia that immediately overlies the sill at the bottom of Hole 856B (Fig. 4) and is characterized by smectite, chlorite, and albite (this study and Davis, Mottl, Fisher, et al., 1992). This zone contains elevated $\mathrm{MgO}$ and $\mathrm{CaO}$ and lower $\mathrm{SiO}_{2}$ contents than Zone Ia-1 (Goodfellow and Peter, this volume).

Albite (< An 9) after detrital plagioclase was detected in samples above the mafic sill (e.g., Sample 139-856B-15X-CC, 20-22 cm; 118.22 mbsf; Table 3; Fig. 12A). Chlorite adjacent to chalcopyrite 

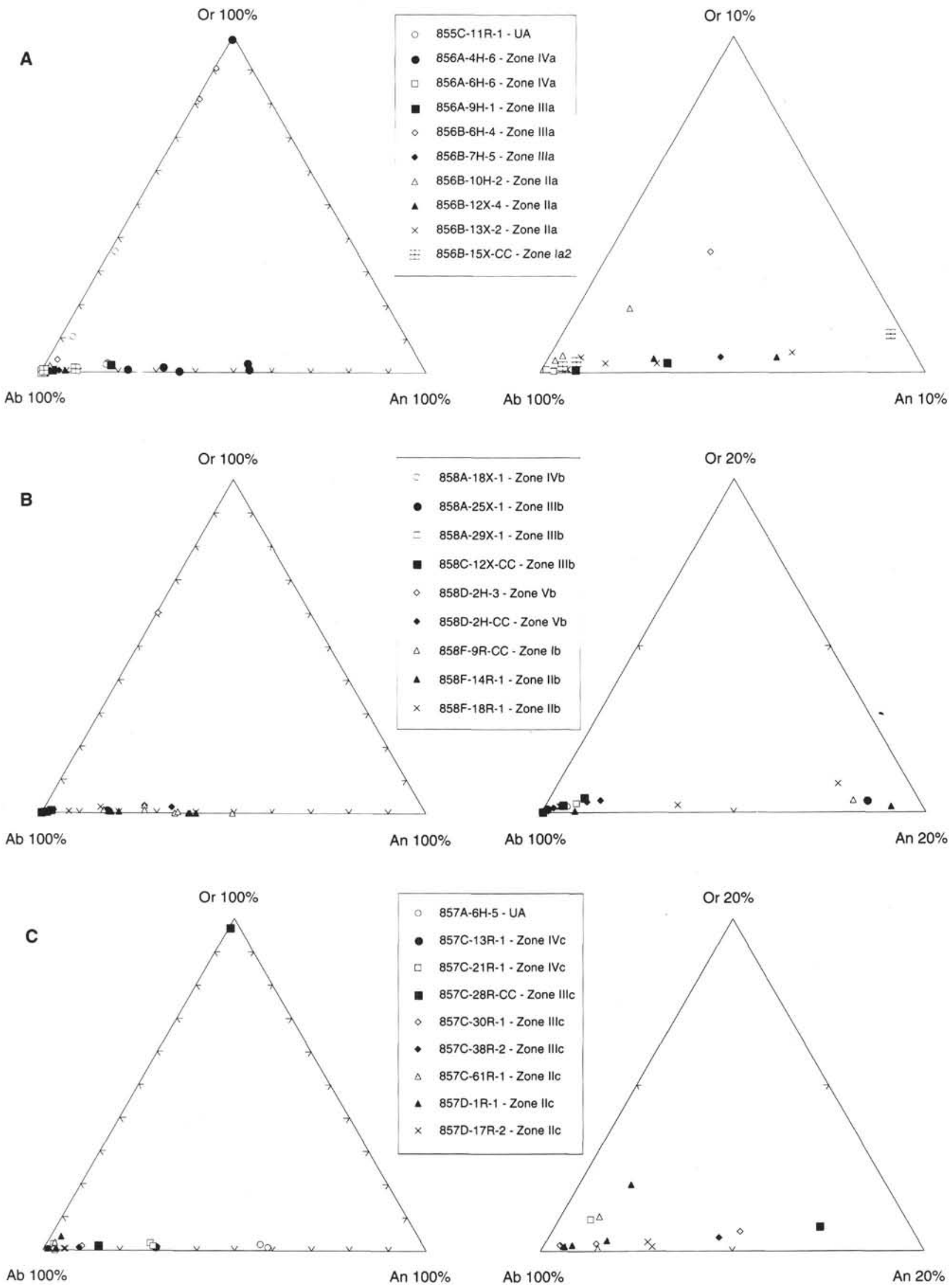

Figure 12. Ternary orthoclase (Or)-albite (Ab)-anorthite (An) diagram for feldspar minerals. A. Sites 855 and 856 . B. Site 858. C. Site 857. Data from Table 3. 
Table 2. X-ray diffraction mineralogy for Leg 139 bulk samples. ${ }^{a}$

\begin{tabular}{|c|c|c|c|c|c|c|c|c|c|c|c|c|c|c|c|c|c|}
\hline $\begin{array}{l}\text { Core, section, } \\
\text { interval }(\mathrm{cm})\end{array}$ & $\begin{array}{l}\text { Depth } \\
\text { (mbsf) }\end{array}$ & $\mathrm{Qz}$ & $\mathrm{Pl}$ & $\mathrm{Am}$ & $\mathrm{Ch}$ & Il & $\mathrm{Ca}$ & $\mathrm{Sm}$ & Ta & Py & $\mathrm{Mr}$ & $\mathrm{Se}$ & Do & $\mathrm{Si}$ & Gy & An & Wa \\
\hline \multicolumn{18}{|l|}{ 139-855C- } \\
\hline IR-1, 57-61 & 0.57 & $x x x x$ & $\mathrm{xxx}$ & & $x x x$ & $\mathrm{xx}$ & $\mathrm{xxx}$ & $\mathrm{x}$ & & & & & & & & & \\
\hline $2 \mathrm{R}-1,53-57$ & $\begin{array}{r}9.23 \\
18.15\end{array}$ & $x x x x$ & $x x x x$ & $\mathrm{x}$ & $\mathrm{xxx}$ & $\mathrm{x}$ & & & & & & & & & & & \\
\hline $3 \mathrm{R}-1,45-47$ & 18.15 & $x x x x$ & $\mathrm{xxx}$ & $\mathrm{xx}$ & $x x x x$ & $x x x$ & $\mathrm{x}$ & $x x$ & & & & & & & & & \\
\hline 10R-1, 130-134 & 86.20 & $x x x x$ & $\mathrm{xxx}$ & $\mathrm{xx}$ & $x x x x$ & $x x x$ & $\mathrm{x}$ & $\mathrm{xx}$ & & & & & & & & & \\
\hline $11 \mathrm{R}-1,115-119$ & 95.75 & $x x x x$ & $x x x$ & $\mathrm{xx}$ & $\mathrm{xxx}$ & & & & & & & & & & & & \\
\hline \multicolumn{18}{|l|}{ 139-856B- } \\
\hline $7 \mathrm{H}-5,26-32$ & 55.56 & $x x x x$ & $\mathrm{xxx}$ & & $\mathrm{xxx}$ & $\mathrm{xx}$ & & & & & & & & & & & \\
\hline $13 \mathrm{X}-2,63-67$ & 93.23 & $x x x x$ & $x x x x$ & & $\mathrm{xxx}$ & $\mathrm{x}$ & & & & & & & & & & & \\
\hline $14 \mathrm{X}-1,34-36$ & 101.14 & $x x x x$ & & & $x x x$ & $\mathrm{xx}$ & & & & & & & & & & & \\
\hline $15 X-1,91-93$ & 111.31 & $x x x x$ & & & $x x x x$ & $\mathrm{x}$ & & & & & & & & & & & \\
\hline $15 X-1,124-126$ & 111.64 & $x x x x$ & & & $x x x x$ & $\mathrm{x}$ & & & & & & & & & & & \\
\hline $15 X-2,67-69$ & 112.57 & $x \mathrm{xxx}$ & & & $\mathrm{xxxx}$ & $\mathrm{x}$ & & & & & & & & & & & \\
\hline $15 X-3,8-10$ & 113.48 & $x x x x$ & & & $x x x x$ & $x$ & & & & & & & & & & & \\
\hline $15 X-4,12-14$ & 115.02 & $\mathrm{xxxx}$ & & & $x x x x$ & $\mathrm{x}$ & $x$ & $x x x$ & & & & & & & & & \\
\hline $\begin{array}{l}\text { 15X-5, 106-108 } \\
\text { 15X-CC, 20-22 }\end{array}$ & $\begin{array}{l}117.46 \\
118.22\end{array}$ & $\begin{array}{l}x x x x \\
x x x x\end{array}$ & $x x x$ & & $\begin{array}{l}x x x x \\
x x x x\end{array}$ & & $\mathrm{x}$ & $\begin{array}{l}x \times x \\
x x x\end{array}$ & & & & & & & & & \\
\hline 139-856D- & & & & & & & & & & & & & & & & & \\
\hline 1H-1, 34-37 & 0.34 & & & & & & & & & $x x x x$ & $\mathrm{xxx}$ & & & & & & \\
\hline $1 \mathrm{H}-2,57-59$ & 2.07 & $x x x x$ & & & & & & & $\mathrm{xxx}$ & $\mathrm{xxx}$ & & & & & & & \\
\hline $1 \mathrm{H}-3,16-20$ & 3.16 & & & & & & & & $\mathrm{x}$ & $x x x x$ & & & & & & & \\
\hline 1H-5, 66-69 & 6.66 & $\mathrm{xxx}$ & & & & & & & $x x$ & $x x x x$ & & & & & & & \\
\hline $1 \mathrm{H}-7,46-48$ & 7.89 & $\mathrm{xxx}$ & & & & & & & & $x x x x$ & & & & & & & \\
\hline \multicolumn{18}{|l|}{$139-856 \mathrm{E}-$} \\
\hline $1 \mathrm{H}-1,48-50$ & 0.48 & $x x x x$ & $x x$ & & & & & & & $\mathrm{xxx}$ & & & & & & & \\
\hline $1 \mathrm{H}-1,73-75$ & 0.73 & $x x x x$ & $\mathrm{xx}$ & & $\mathrm{xx}$ & & & & & & & & & & & & \\
\hline $1 \mathrm{H}-1,129-131$ & 1.29 & & & & & & & & & $x x x x$ & $\mathrm{xx}$ & & & $\mathrm{xxx}$ & & & \\
\hline $1 \mathrm{H}-2,55-57$ & 2.05 & & & & & & & & & $x \mathrm{xxx}$ & $\mathrm{xx}$ & & & & & & \\
\hline & & & & & & & & & & & & & & & & & \\
\hline $2 \mathrm{R}-2,54-56$ & 10.64 & $x x x x$ & & & & & & & $\mathrm{xxxx}$ & $\mathrm{xx}$ & & & & & & & \\
\hline $\begin{array}{l}\text { 6R-3, 132-134 } \\
7 \mathrm{R}-4,35-37\end{array}$ & $\begin{array}{l}50.62 \\
60.45\end{array}$ & & & & & & & & & $\mathrm{xx}$ & & $\begin{array}{l}x x x \\
x x x x\end{array}$ & & & & & \\
\hline $139-856 \mathrm{H}-$ & 60.43 & & & & & & & & & $x x x$ & & & & & & & \\
\hline $\begin{array}{l}139-856 \mathrm{H}- \\
3 \mathrm{R}-3,72-74\end{array}$ & 25.43 & & & & $x x x$ & & & & & $x x$ & & & $\mathrm{xxxx}$ & & & & \\
\hline $4 \mathrm{R}-1,21-23$ & 26.81 & & & & $x x x x$ & & $\mathrm{xx}$ & & $x x x$ & & & & $\mathrm{xx}$ & & & & \\
\hline $4 \mathrm{R}-1,88-90$ & 27.48 & & & & $\mathrm{xxx}$ & & & & $x x x x$ & $\mathrm{xx}$ & & & & & & & \\
\hline $4 \mathrm{R}-2,43-45$ & 28.53 & & & & $x x x x$ & & & & & $x x x$ & & & & & & & \\
\hline $4 \mathrm{R}-3,16-17$ & 29.72 & & & & $x x x x$ & & $\mathrm{xxx}$ & & & $x x x$ & & & & & & & \\
\hline $6 \mathrm{R}-1,39-41$ & 37.79 & & & & & & & & & $\mathrm{xxx}$ & & & & & & & \\
\hline $9 \mathrm{R}-1,68-70$ & 53.18 & & & & & & & & $x x x x$ & $x x x x$ & & & & & & & \\
\hline $11 \mathrm{R}-1,114-117$ & 62.44 & & & & & & & & & $x x$ & & & & $x x x x$ & & & \\
\hline $139-857 \mathrm{C}$ - & & & & & & & & & & & & & & & & & \\
\hline $2 \mathrm{R}-2,6-10$ & 58.06 & $x x x x$ & $x x x$ & $\mathrm{x}$ & $x x x$ & & $\mathrm{x}$ & & & & & & & & & & \\
\hline $3 R-3,110-112$ & 70.60 & $x x x x$ & $x x x$ & $\mathrm{x}$ & $x x x$ & $\mathrm{x}$ & $\mathrm{x}$ & & & & & & & & & & \\
\hline $10 \mathrm{R}-1,65-67$ & 124,75 & $x x x x$ & $x x x$ & & $x x x$ & $\mathrm{x}$ & & & & & & & & & & & \\
\hline $13 R-3,52-54$ & $\begin{array}{l}156.62 \\
17307\end{array}$ & $x x x x$ & $x x x x$ & & $\mathrm{xx}$ & & $\mathrm{x}$ & & & & & & & & & & \\
\hline $\begin{array}{l}15 \mathrm{R}-1,147-149 \\
17 \mathrm{R}-2,61-65\end{array}$ & & $\begin{array}{l}x x x x \\
x x x x\end{array}$ & $\begin{array}{c}x x x \\
x x x x\end{array}$ & & $\begin{array}{l}x x \\
x x\end{array}$ & & $x x x$ & & & & & & & & & & \\
\hline $\begin{array}{l}1 / \mathrm{R}-2,61-63 \\
2 \mathrm{IR}-1,24-26\end{array}$ & $\begin{array}{l}194.01 \\
230.84\end{array}$ & $\begin{array}{l}x x x x \\
x x x x\end{array}$ & $\begin{array}{l}x x x x \\
x x x x\end{array}$ & & $\begin{array}{l}x x \\
x x x\end{array}$ & $x x$ & & & & & & & & & & & \\
\hline $22 \mathrm{R}-\mathrm{CC}, 1-5$ & 242.01 & $x x x$ & $x x x$ & & & & $x x x x$ & & & & & & & & & & \\
\hline 28R-2, 119-122 & 296.49 & $x x x x$ & $x x x x$ & & $x x x$ & & & & & & & & & & & & \\
\hline $30 \mathrm{R}-1,116-120$ & 314.26 & $x x x x$ & $x \times x x$ & & $x x x$ & $\mathrm{x}$ & & & & & & & & & & & \\
\hline $38 R-2,50-53$ & 357.80 & $x x x x$ & $x x x x$ & & $x x x$ & $\mathrm{x}$ & $\mathrm{xxx}$ & & & & & & & & & & \\
\hline $\begin{array}{l}44 \mathrm{R}-1,137-140 \\
53 \mathrm{R}-1,50-52\end{array}$ & $\begin{array}{l}391.07 \\
433.30\end{array}$ & $\begin{array}{c}x x x x \\
x x x\end{array}$ & $\begin{array}{l}x x x x \\
x x x x\end{array}$ & & $\begin{array}{l}x x x \\
x x x x\end{array}$ & $\begin{array}{c}\mathrm{xx} \\
\mathrm{x}\end{array}$ & $\mathrm{x}$ & & & & & & & & & & \\
\hline 139-857D- & & & & & & & & & & & & & & & & & \\
\hline IR-1, 137-139 & 582.87 & $x x x x$ & $\mathrm{xxx}$ & & $x x x$ & & & & & & & & & & & & \\
\hline $5 R-1,26-28$ & 618.86 & $x x x x$ & & & $x x x$ & & & & & & & & $\mathrm{xxx}$ & & & & \\
\hline $14 \mathrm{R}-1,22-25$ & & $x x x x$ & $x x x$ & & $x x x$ & & & & & & & & & & & & \\
\hline & 735.50 & $x x x x$ & $\mathrm{xxx}$ & & $\mathrm{xxx}$ & & & & & & & & & & & & \\
\hline 2 IR-2, 14-16 & 773.84 & $x x x x$ & $\mathrm{xxx}$ & & $x x x x$ & & & & & & & & & & & & \\
\hline $28 \mathrm{R}-1,67-69$ & 839.57 & $x x x x$ & $\mathrm{xxx}$ & & $x x x$ & & & & & & & & & & & & \\
\hline 139-858A- & & & & & & & & & & & & & & & & & \\
\hline $1 \mathrm{H}-2,5-7$ & 1.55 & $x x x x$ & $x x x$ & & $x$ & $\mathrm{x}$ & $\mathrm{x}$ & & & & & & & & & & \\
\hline $2 \mathrm{H}-1,125-127$ & 3.65 & $x x x x$ & $x x x$ & $\mathrm{x}$ & $x x x$ & $x x$ & $x x$ & & & & & & & & & & \\
\hline $3 \mathrm{H}-4,29-33$ & 16.46 & $x x x x$ & $x x x$ & $x$ & $x x$ & $x x$ & & & & & & & & & & & \\
\hline $4 \mathrm{H}-6,48-50$ & 29.38 & $x x x x$ & $x x x$ & & $x x x$ & $x x$ & $x x$ & & & & & & & & & & \\
\hline $5 \mathrm{H}-5,54-57$ & 37.44 & $x x x x$ & $x x x$ & & $x x x$ & $x x$ & $\mathrm{xx}$ & & & & & & & & & & \\
\hline $6 \mathrm{H}-3,77-79$ & 44.17 & $x x x x$ & $x x x$ & & $x x x$ & & $\mathrm{xx}$ & & & & & & & & & & \\
\hline $9 \times-4,52-56$ & 67.52 & $x x x x$ & $\mathrm{xx}$ & & $\mathrm{xxx}$ & $\mathrm{xx}$ & $x x$ & & & & & & & & & & \\
\hline $11 \mathrm{X}-\mathrm{CC}, 10-12$ & 73.57 & $x x x x$ & $x x x$ & & $x \mathrm{x}$ & & $x$ & & & & & & & & & & \\
\hline $15 X-1,35-37$ & 110.95 & $\mathrm{xxxx}$ & $\mathrm{xxx}$ & & $\mathrm{xxx}$ & $\mathrm{xx}$ & $\mathrm{xx}$ & & & & & & & & & & \\
\hline $18 X-1,116-118$ & 140.76 & $x x x x$ & $x x x$ & & $x x x$ & $\mathrm{x}$ & & & & & & & & & & & \\
\hline $20 X-4,100-103$ & 164.44 & $x x x x$ & $\mathrm{xxx}$ & & $x x x x$ & $\mathrm{xx}$ & & & & & & & & & $x \mathrm{xx}$ & & \\
\hline & $\begin{array}{l}171.98 \\
197.93\end{array}$ & $\begin{array}{l}x x x x \\
x x x x\end{array}$ & $\begin{array}{c}x x x \\
x x x x\end{array}$ & & $\begin{array}{c}x x x \\
x x x x\end{array}$ & $\begin{array}{l}x x \\
x x\end{array}$ & & & & & & & & & $\begin{array}{l}x x x \\
x x x\end{array}$ & $x x x x$ & \\
\hline $\begin{array}{l}24 \mathrm{X}-1,33-35 \\
25 \mathrm{X}-1,29-32\end{array}$ & $\begin{array}{l}197.93 \\
207.59\end{array}$ & $\begin{array}{l}x x x x \\
x x x x\end{array}$ & $\begin{array}{l}x x x x \\
x x x\end{array}$ & & $\begin{array}{l}x x x x \\
x x x x\end{array}$ & $\begin{array}{l}x x \\
x x\end{array}$ & & & & & & & & & & & \\
\hline $29 \mathrm{X}-1,30-32$ & 246.20 & $x x x x$ & $x x x$ & & $x x x$ & & & & & & & & & & $\mathrm{x}$ & $x x x x$ & \\
\hline
\end{tabular}


Table 2 (continued).

\begin{tabular}{|c|c|c|c|c|c|c|c|c|c|c|c|c|c|c|c|c|c|}
\hline $\begin{array}{l}\text { Core, section, } \\
\text { interval }(\mathrm{cm})\end{array}$ & $\begin{array}{l}\text { Depth } \\
\text { (mbsf) }\end{array}$ & $\mathrm{Qz}$ & $\mathrm{Pl}$ & $\mathrm{Am}$ & $\mathrm{Ch}$ & II & $\mathrm{Ca}$ & $\mathrm{Sm}$ & $\mathrm{Ta}$ & Py & $\mathrm{Mr}$ & $\mathrm{Se}$ & Do & $\mathrm{Si}$ & Gy & An & Wa \\
\hline \multicolumn{18}{|l|}{$139-858 \mathrm{~B}-$} \\
\hline $1 \mathrm{H}-2,21-23$ & 1.71 & $\mathrm{x}$ & & & $x x$ & & & & & & & & & & & & \\
\hline $1 \mathrm{H}-2,50-54$ & 2.00 & $x x x x$ & $x x x$ & $\mathrm{x}$ & $x x x$ & $x x$ & $x x x$ & & & & & & & & & & \\
\hline $1 \mathrm{H}-\mathrm{CC}, 8-12$ & 6.98 & $x x x x$ & $x x x$ & & $x x x$ & $x x$ & & & & $\mathrm{xx}$ & & & & & & & \\
\hline $2 \mathrm{H}-6,69-71$ & 15.39 & $x x x x$ & $x x x$ & & & $x x$ & & & & & & & & & & & \\
\hline $5 \mathrm{H}-3,118-121$ & 28.08 & $\mathrm{xx}$ & & & $\mathrm{xxxx}^{\mathrm{b}}$ & & & & & & & & & & & & \\
\hline $5 \mathrm{H}-4,27-29$ & 28.67 & & & & $x \times x x^{b}$ & & & & & & & & & & & & \\
\hline \multicolumn{18}{|l|}{$139-858 \mathrm{~F}-$} \\
\hline $2 \mathrm{R}-\mathrm{CC}, 7-10$ & 27.87 & $x x x x$ & & & $x x x$ & & & & & & & & & & & & $x x x$ \\
\hline 9R-CC, 9-11 & 94.29 & $x x x x$ & & & $x x$ & & & & & & & & & & & & $x x x x$ \\
\hline $14 \mathrm{R}-1,10-12$ & 142.70 & $x x x x$ & $x x x x$ & & $x x x$ & & & & & & & & & & & & \\
\hline $18 \mathrm{R}-1,14-16$ & 181.44 & $x \times x x$ & $x x x$ & & $x x x$ & & & & & & & & & & & & $\mathrm{xx}$ \\
\hline $25 \mathrm{R}-1,71-73$ & 249.61 & $x x x x$ & $x x x x$ & & $x x x x$ & & & & & & & & & & & & \\
\hline
\end{tabular}

Notes: $\mathrm{xxxx}=$ major; $\mathrm{xxx}=$ minor, $\mathrm{xx}=$ trace; $\mathrm{x}=$ slight trace; $\mathrm{Qz}=$ quartz; $\mathrm{Pl}=$ plagioclase feldspar; $\mathrm{Am}=$ amphibole; $\mathrm{Ch}=$ chlorite; $\mathrm{Il}=$ illite $\mathrm{Ca}=$ calcite $; \mathrm{Sm}$ = smectite $; \mathrm{Ta}=$ talc $; \mathrm{Py}=$ pyrite $\mathrm{Mr}=$ marcasite $\mathrm{Se}=$ serpentine $; \mathrm{Do}=$ dolomite; $\mathrm{Si}=$ siderite $; \mathrm{Gy}=$ gypsum; $\mathrm{An}=$ anhydrite $; \mathrm{Wa}=$ wairakite .

a Relative mineral abundances were determined from peak heights.

b Vermiculite, possibly.

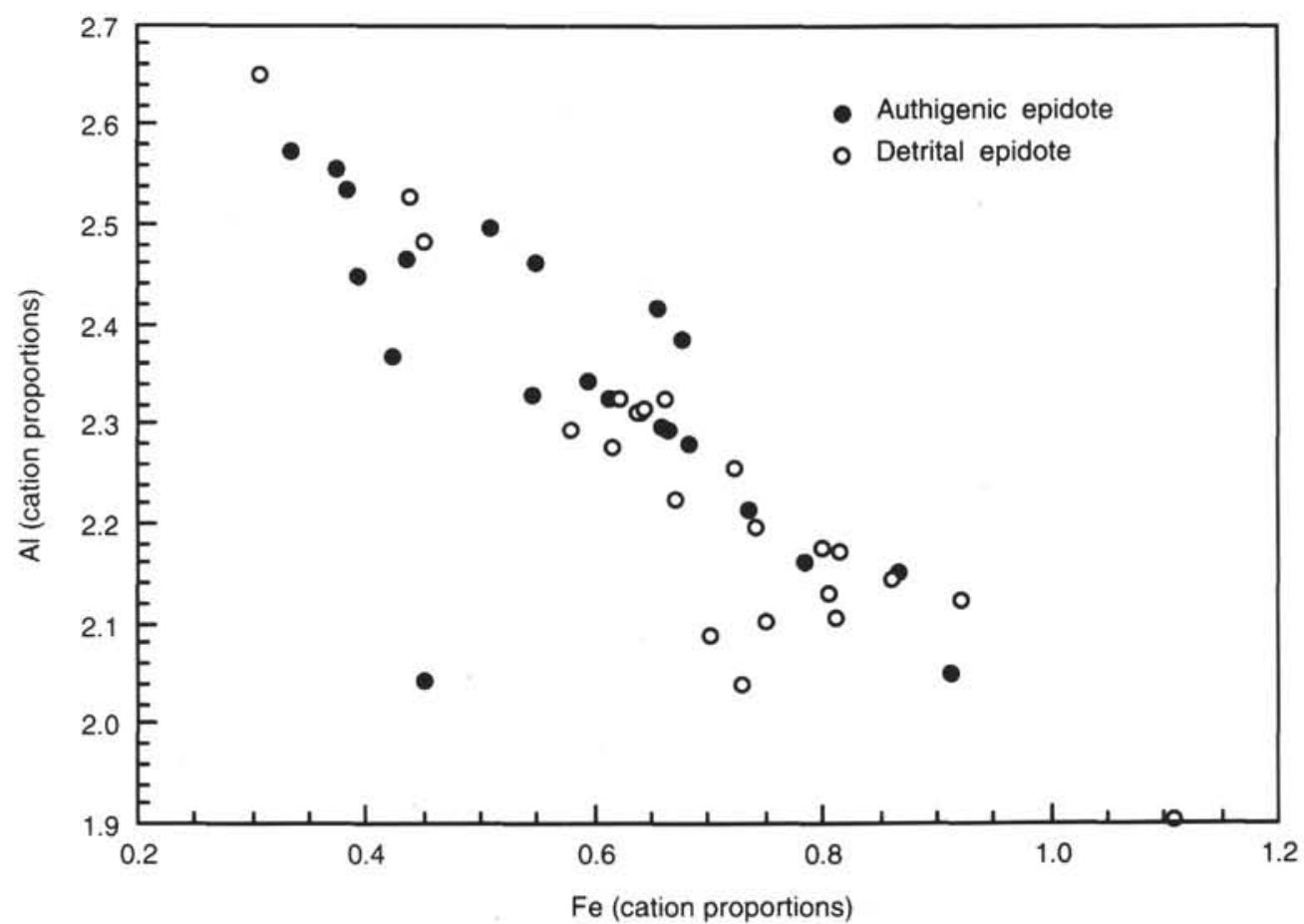

Figure 13. Fe vs. Al (cation proportions) of epidote, showing difference between detrital and authigenic epidote for all sites. Data from Table 4.

veins plots near the Mg-rich end of the chlorite field for Core 139. 856B-15X (Sample 139-856B-15X-CC, 20-22 cm; Figs. 15B and 16). Smectite was detected in Sample 139-856B-15X-CC, 20-22 cm immediately above the mafic sill. This sample also contains elevated $\mathrm{MgO}$ contents compared to other samples in Core 139-856B-15X, suggesting that the smectite is a hydrothermal saponite. Tabular barite crystals up to $6 \mathrm{~mm}$ in length occur with chalcopyrite in veins below 111 mbsf (e.g., Sample 139-856B-15C-CC, 20-22 cm; Davis, Mottl, Fisher, et al., 1992).

\section{Hydrothermal Minerals in Massive Sulfides}

Hydrothermal quartz ranges up to 70 vol\% (e.g., Sample 139$856 \mathrm{G}-2 \mathrm{R}-2,54-56 \mathrm{~cm}$ ) in massive sulfides from Holes $856 \mathrm{D}$ through $856 \mathrm{H}$. This quartz consists of euhedral to anhedral crystals up to 400 $\mu \mathrm{m}$ in diameter (typically $<100 \mu \mathrm{m}$ ) that commonly display a hexagonal morphology (Pl. 2, Fig. 1), undulose extinction and concentric (growth?) zonation of fluid inclusions (PI. 2, Figs. 2 and 3). Quartz also cements sulfide clasts.
Talc occurs in Hole $856 \mathrm{~B}$ as a fine-grained network interstitial to collomorphic and euhedral pyrite (Sample 139-856B-3H-5, 110-113 $\mathrm{cm}$; Pl. 2, Figs. 3-6). Talc displays minor Fe substitution for $\mathrm{Mg}$ and low $\mathrm{Al}$ contents (Table 9; Fig. 15D,E). The low $\mathrm{Al} / \mathrm{Mg}$ ratios of clastic sulfide samples in Hole $856 \mathrm{~B}$ are in agreement with talc that occurs with massive sulfides in shallow cores (Goodfellow and Franklin, in press). Talc is the dominant Mg-silicate in Holes $856 \mathrm{D}-856 \mathrm{H}$ (Tables 2 and 8; Fig. 15D,E; Pl. 2, Figs. 3 and 6) although some samples from Hole $856 \mathrm{E}$ also contain hemipelagic components, mostly chlorite, quartz, and feldspar. Authigenic clays occur interstitially to pyrite and barite (Sample 139-856D-1H-2, 43-46 cm) and have locally replaced barite. Below 49 mbsf in Hole $856 \mathrm{G}$, serpentine occurs with talc (Tables 2 and 9).

Hemipelagic sediment occurs interbedded with massive sulfides between 25 and 30 mbsf in Hole $856 \mathrm{H}$ (Cores $139-856 \mathrm{H}-3 \mathrm{R}$ and $139-856 \mathrm{H}-4 \mathrm{R}$ ) and may represent a hiatus in hydrothermal sedimentation. These sediments are intensely altered and crosscut by an anastomosing network of pyrrhotite-pyrite-sphalerite-chalcopyrite veins. The sediment is altered to chlorite, talc, and smectite (saponite?); this 


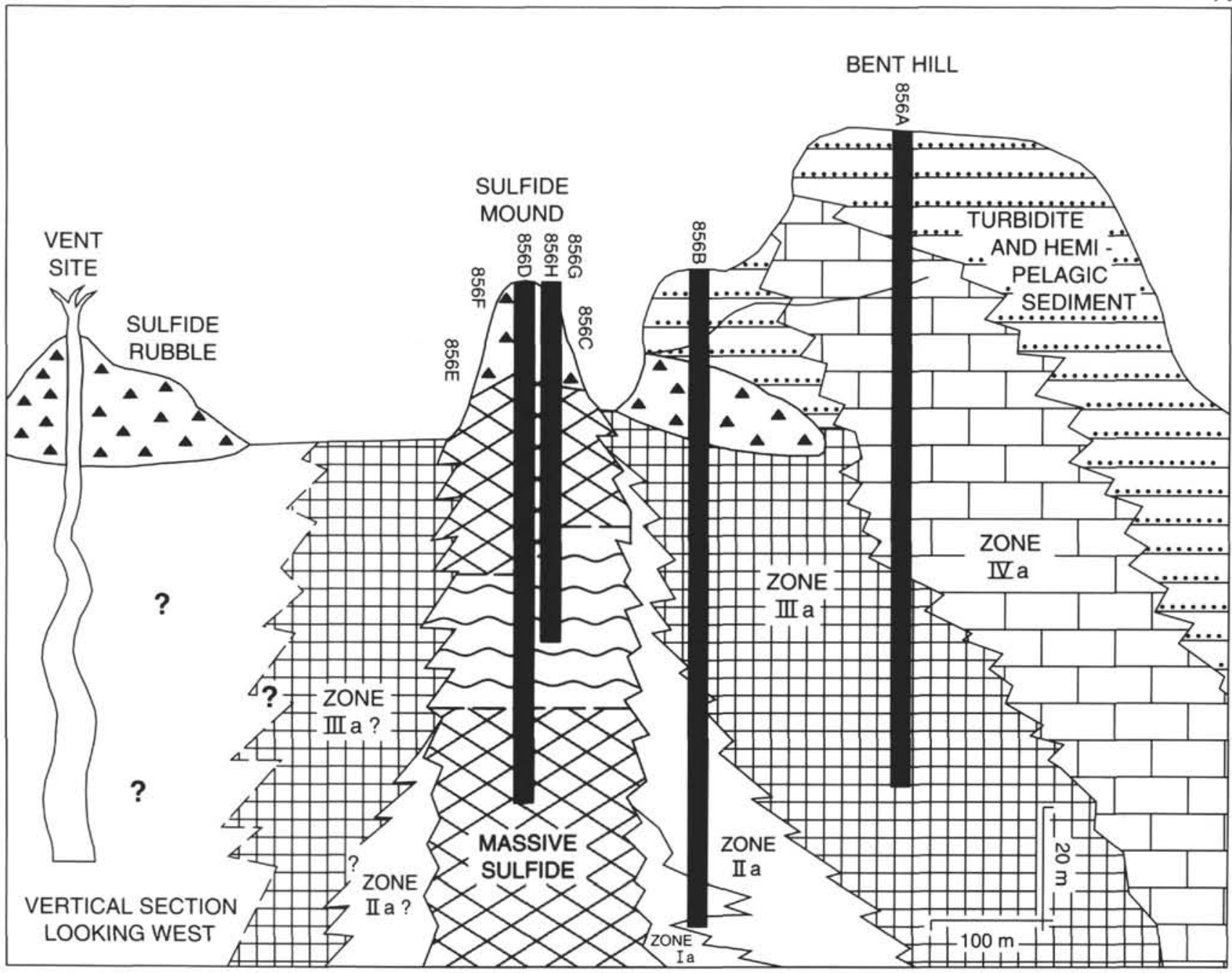

Figure 14. North-south profile of Site 856 (Bent Hill and sulfide mounds) showing the distribution of the alteration zones about the Bent Hill massive sulfide deposit. Zone characteristics are given in the text and in Table 5 .

smectite has variable $\mathrm{Al}$ contents and plots between chlorite and talc on a Fe-Al-Mg diagram (Table 9; Fig. 15D). Chlorite from Samples $139-856 \mathrm{H}-3 \mathrm{R}-3,72-74 \mathrm{~cm}$ and $139-856 \mathrm{H}-4 \mathrm{R}-1,88-90 \mathrm{~cm}$ is enriched in $\mathrm{MgO}$ compared with most chlorites from Core 139-856B$15 \mathrm{X}$ (Fig. 15B; Pl. 3, Fig. 1). Some clay minerals in Sample 139$856 \mathrm{H}-3 \mathrm{R}-3,72-74 \mathrm{~cm}$ are $\mathrm{FeO}$-rich and $\mathrm{SiO}_{2}$ - and $\mathrm{Al}_{2} \mathrm{O}_{3}$-poor (Table 9), plot above the chlorite field in Figure 15, and are compositionally similar to nontronite.

Barite is erratically distributed and forms up to $10-15$ vol\% (Sample $139-856 \mathrm{D}-1 \mathrm{H}-1,34-37 \mathrm{~cm}$ ). Its abundance is consistent with bulk contents that range up to 8.8 weight percent (wt\%) Ba (Goodfellow and Peter, this volume). Barite forms isolated crystals up to $600 \mu \mathrm{m}$ in length, rosettes (Pl. 3, Fig. 2), and aggregates of broken, finegrained crystals. The $\mathrm{SrO}$ content of barite ranges up to $3.6 \mathrm{wt} \%$ (Table 10).

Dolomite is the dominant carbonate phase in Hole $856 \mathrm{G}$ and Hole $856 \mathrm{H}$ although calcite, siderite, and magnesite are also present ( $\mathrm{Pl} .3$, Figs. 3 and 4; Table 11; Fig. 17A). Individual dolomite crystals are up to $400 \mu \mathrm{m}$ in diameter and are coarser grained and less altered near the center of carbonate veins and masses than at the edges. Magnesite typically displays a more elongate, feathery habit than the other carbonate minerals (PI. 3, Fig. 3). Fe in dolomite commonly shows oscillatory zoning (Pl. 3, Figs. 5 and 6) and dolomite grains are commonly overgrown by later magnetite (Pl. 3, Fig. 5).

\section{Site 858 (Area of Active Venting)}

Six different hydrothermal alteration zones (Table 5) are recognized at Site 858 ; these are distributed laterally and vertically about the center of hydrothermal fluid discharge (Fig. 18). The textural and mineralogical characteristics are discussed below for each zone, from the margins to the core of fluid upflow.

\section{Zone VIb}

This zone consists of Mg-smectite (saponite), talc, dolomite, and pyrite between 24 and $38 \mathrm{mbsf}$ in Hole 858B (Fig. 6). Below $24 \mathrm{mbsf}$, the sediments are brecciated, infilled and/or replaced by $\mathrm{Mg}$-rich clays (saponite or vermiculite), chlorite (Table 2), and anhydrite, and cut by quartz and anhydrite veins. Bulk sediment contains up to $30 \mathrm{wt} \% \mathrm{MgO}$ (Goodfellow and Peter, this volume). Saponitic muds also occur in the uppermost two meters of Hole 858B (Fig. 6), as has been previously reported for shallow cores from AAV (Goodfellow et al., in press).

\section{Zone $\mathrm{Vb}$}

This zone consists of calcite( \pm dolomite)-illite-pyrite and occurs between 15 and $80 \mathrm{mbsf}$ in Hole 858A (Fig. 5), 2 and $17 \mathrm{mbsf}$ in Hole $858 \mathrm{C}$ (Fig. 7), and 0 and $20 \mathrm{mbsf}$ in Hole 858D (Fig. 8). Carbonate 
Table 3. Electron microprobe data for detrital and authigenic feldspar in unaltered and hydrothermally altered hemipelagic and turbiditic sediment, Leg 139.

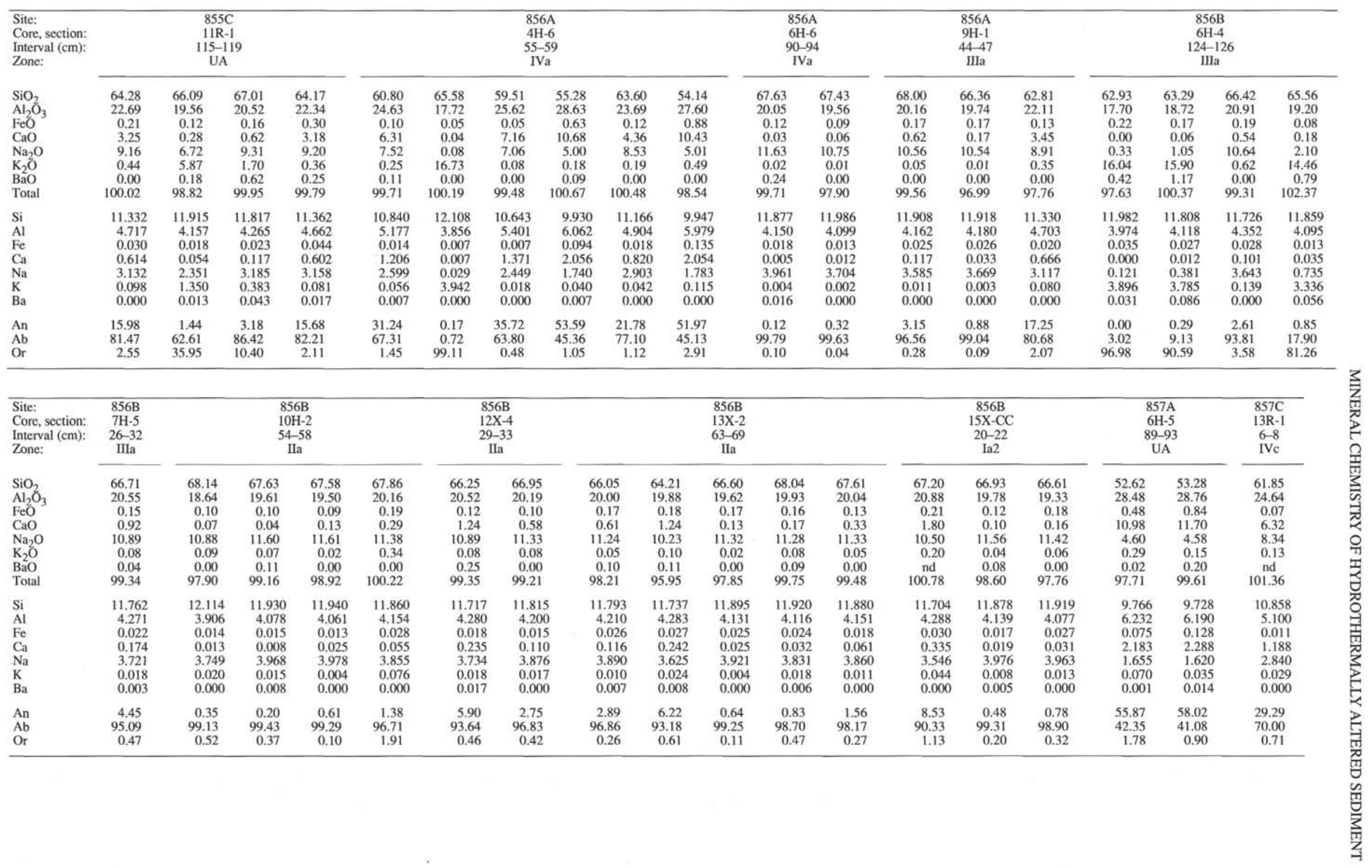


Table 3 (continued).

\begin{tabular}{|c|c|c|c|c|c|c|c|c|c|c|c|c|c|c|c|c|c|c|c|}
\hline $\begin{array}{l}\text { Site: } \\
\text { Core, section: } \\
\text { Interval }(\mathrm{cm}) \text { : } \\
\text { Zone: }\end{array}$ & & $\begin{array}{l}857 \mathrm{C} \\
21 \mathrm{R}-1 \\
24-26 \\
\mathrm{IVc}\end{array}$ & & $\begin{array}{r}85 \\
28 \mathrm{R} \\
\text { II }\end{array}$ & & & $\begin{array}{c}857 \mathrm{C} \\
30 \mathrm{R}-1 \\
116-120 \\
\mathrm{IIc}\end{array}$ & & $\begin{array}{c}857 \mathrm{C} \\
38 \mathrm{R}-2 \\
50-53 \\
\mathrm{IIIc}\end{array}$ & $\begin{array}{r}85 \\
61 \\
129 \\
1\end{array}$ & $\begin{array}{l}\text { RC } \\
\text { R-1 } \\
-131 \\
\text { Ic }\end{array}$ & & & $\begin{array}{l}7 \mathrm{D} \\
-1 \\
-139 \\
\mathrm{c}\end{array}$ & & & $\begin{array}{l}857 \mathrm{D} \\
17 \mathrm{R}-2 \\
53-55 \\
\text { IIa }\end{array}$ & & $\begin{array}{c}858 \mathrm{~A} \\
18 \mathrm{X}-1 \\
116-118 \\
\mathrm{IVb}\end{array}$ \\
\hline $\begin{array}{l}\mathrm{SiO}_{2} \\
\mathrm{Al}_{2} \mathrm{O}_{3} \\
\mathrm{FeO} \\
\mathrm{CaO} \\
\mathrm{Na}_{2} \mathrm{O} \\
\mathrm{K}_{2} \mathrm{O} \\
\mathrm{BaO} \\
\text { Total }\end{array}$ & $\begin{array}{r}62.13 \\
23.88 \\
0.30 \\
5.48 \\
8.09 \\
0.41 \\
\text { nd } \\
100.29\end{array}$ & $\begin{array}{r}70.80 \\
20.28 \\
0.24 \\
0.35 \\
11.46 \\
0.35 \\
\text { nd } \\
103.47\end{array}$ & $\begin{array}{r}61.90 \\
24.37 \\
0.20 \\
5.97 \\
8.34 \\
0.22 \\
\text { nd } \\
100.99\end{array}$ & $\begin{array}{r}65.72 \\
21.67 \\
0.02 \\
2.90 \\
9.84 \\
0.26 \\
\text { nd } \\
100.41\end{array}$ & $\begin{array}{r}64.96 \\
18.38 \\
0.13 \\
0.03 \\
0.30 \\
16.54 \\
\text { nd } \\
100.33\end{array}$ & $\begin{array}{r}68.24 \\
19.95 \\
0.14 \\
0.58 \\
11.57 \\
0.09 \\
\text { nd } \\
100.57\end{array}$ & $\begin{array}{r}70.37 \\
20.22 \\
0.19 \\
0.18 \\
11.79 \\
0.06 \\
\text { nd } \\
102.81\end{array}$ & $\begin{array}{r}67.20 \\
21.47 \\
0.21 \\
2.16 \\
10.78 \\
0.22 \\
\text { nd } \\
102.03\end{array}$ & $\begin{array}{c}66.55 \\
21.63 \\
0.68 \\
1.86 \\
10.44 \\
0.14 \\
\text { nd } \\
101.30\end{array}$ & $\begin{array}{r}69.26 \\
19.72 \\
0.19 \\
0.45 \\
11.52 \\
0.39 \\
\text { nd } \\
101.53\end{array}$ & $\begin{array}{r}69.09 \\
20.24 \\
0.11 \\
0.64 \\
11.60 \\
0.03 \\
\text { nd } \\
101.71\end{array}$ & $\begin{array}{r}66.38 \\
21.35 \\
0.22 \\
0.56 \\
10.73 \\
0.70 \\
0.07 \\
100.01\end{array}$ & $\begin{array}{r}68.19 \\
20.67 \\
0.06 \\
0.65 \\
11.04 \\
0.11 \\
0.00 \\
100.72\end{array}$ & $\begin{array}{r}67.48 \\
19.94 \\
0.05 \\
0.31 \\
11.27 \\
0.06 \\
0.07 \\
99.17\end{array}$ & $\begin{array}{r}67.28 \\
19.72 \\
0.04 \\
0.23 \\
11.44 \\
0.05 \\
0.00 \\
98.76\end{array}$ & $\begin{array}{r}67.20 \\
19.54 \\
0.08 \\
0.22 \\
11.43 \\
0.05 \\
0.00 \\
98.51\end{array}$ & $\begin{array}{r}65.94 \\
20.10 \\
0.18 \\
1.19 \\
10.94 \\
0.05 \\
0.00 \\
98.40\end{array}$ & $\begin{array}{r}64.92 \\
20.10 \\
0.13 \\
1.13 \\
11.05 \\
0.10 \\
0.00 \\
97.42\end{array}$ & $\begin{array}{r}69.15 \\
18.28 \\
0.20 \\
0.25 \\
11.71 \\
0.06 \\
\text { nd } \\
99.64\end{array}$ \\
\hline $\begin{array}{l}\mathrm{Si} \\
\mathrm{Al} \\
\mathrm{Fe} \\
\mathrm{Ca} \\
\mathrm{Na} \\
\mathrm{K} \\
\mathrm{Ba}\end{array}$ & $\begin{array}{r}11.002 \\
4.985 \\
0.045 \\
1.040 \\
2.776 \\
0.092 \\
0.000\end{array}$ & $\begin{array}{r}11.964 \\
4.040 \\
0.034 \\
0.063 \\
3.754 \\
0.074 \\
0.000\end{array}$ & $\begin{array}{r}10.903 \\
5.060 \\
0.029 \\
1.126 \\
2.849 \\
0.050 \\
0.000\end{array}$ & $\begin{array}{r}11.517 \\
4.478 \\
0.003 \\
0.545 \\
3.345 \\
0.058 \\
0.000\end{array}$ & $\begin{array}{r}11.988 \\
3.998 \\
0.020 \\
0.006 \\
0.108 \\
3.893 \\
0.000\end{array}$ & $\begin{array}{r}11.882 \\
4.096 \\
0.021 \\
0.108 \\
3.908 \\
0.020 \\
0.000\end{array}$ & $\begin{array}{r}11.958 \\
4.051 \\
0.027 \\
0.033 \\
3.884 \\
0.013 \\
0.000\end{array}$ & $\begin{array}{r}11.596 \\
4.367 \\
0.030 \\
0.398 \\
3.606 \\
0.048 \\
0.000\end{array}$ & $\begin{array}{r}11.566 \\
4.432 \\
0.099 \\
0.346 \\
3.517 \\
0.031 \\
0.000\end{array}$ & $\begin{array}{r}11.951 \\
4.012 \\
0.028 \\
0.082 \\
3.855 \\
0.085 \\
0.000\end{array}$ & $\begin{array}{r}11.886 \\
4.105 \\
0.016 \\
0.117 \\
3.870 \\
0.007 \\
0.000\end{array}$ & $\begin{array}{r}11.660 \\
4.422 \\
0.032 \\
0.106 \\
3.654 \\
0.157 \\
0.004\end{array}$ & $\begin{array}{r}11.830 \\
4.227 \\
0.008 \\
0.121 \\
3.714 \\
0.025 \\
0.000\end{array}$ & $\begin{array}{r}11.892 \\
4.143 \\
0.007 \\
0.058 \\
3.851 \\
0.013 \\
0.005\end{array}$ & $\begin{array}{r}11.905 \\
4.113 \\
0.007 \\
0.044 \\
3.925 \\
0.012 \\
0.000\end{array}$ & $\begin{array}{r}11.923 \\
4.086 \\
0.011 \\
0.042 \\
3.933 \\
0.011 \\
0.000\end{array}$ & $\begin{array}{r}11.757 \\
4.224 \\
0.026 \\
0.228 \\
3.782 \\
0.012 \\
0.000\end{array}$ & $\begin{array}{r}11.705 \\
4.272 \\
0.020 \\
0.218 \\
3.863 \\
0.023 \\
0.000\end{array}$ & $\begin{array}{r}12.129 \\
3.779 \\
0.029 \\
0.047 \\
3.983 \\
0.013 \\
0.000\end{array}$ \\
\hline $\begin{array}{l}\mathrm{An} \\
\mathrm{Ab} \\
\mathrm{Or}\end{array}$ & $\begin{array}{r}26.62 \\
71.04 \\
2.35\end{array}$ & $\begin{array}{r}1.61 \\
96.48 \\
1.91\end{array}$ & $\begin{array}{r}27.97 \\
70.79 \\
1.24\end{array}$ & $\begin{array}{r}13.80 \\
84.73 \\
1.47\end{array}$ & $\begin{array}{r}0.15 \\
2.69 \\
97.16\end{array}$ & $\begin{array}{r}2.68 \\
96.83 \\
0.49\end{array}$ & $\begin{array}{r}0.84 \\
98.82 \\
0.34\end{array}$ & $\begin{array}{r}9.83 \\
88.98 \\
1.19\end{array}$ & $\begin{array}{r}8.90 \\
90.31 \\
0.79\end{array}$ & $\begin{array}{r}2.05 \\
95.83 \\
2.12\end{array}$ & $\begin{array}{r}2.93 \\
96.88 \\
0.19\end{array}$ & $\begin{array}{r}2.71 \\
93.29 \\
4.00\end{array}$ & $\begin{array}{r}3.14 \\
96.23 \\
0.64\end{array}$ & $\begin{array}{r}1.47 \\
98.20 \\
0.33\end{array}$ & $\begin{array}{r}1.10 \\
98.59 \\
0.31\end{array}$ & $\begin{array}{r}1.05 \\
98.68 \\
0.27\end{array}$ & $\begin{array}{r}5.66 \\
94.03 \\
0.31\end{array}$ & $\begin{array}{r}5.31 \\
94.12 \\
0.57\end{array}$ & $\begin{array}{r}1.15 \\
98.53 \\
0.32\end{array}$ \\
\hline
\end{tabular}

\begin{tabular}{|c|c|c|c|c|c|c|c|c|c|c|c|c|c|c|c|c|c|c|c|}
\hline $\begin{array}{l}\text { Site: } \\
\text { Core, section: } \\
\text { Interval }(\mathrm{cm}) \text { : } \\
\text { Zone: }\end{array}$ & & $\begin{array}{l}8 \mathrm{~B} \\
\mathrm{~K}-1 \\
-33 \\
\mathrm{Bb}\end{array}$ & $\begin{array}{c}858 \mathrm{~A} \\
29 \mathrm{X}-1 \\
30-32 \\
\text { IIIb }\end{array}$ & $\begin{array}{c}858 \mathrm{C} \\
5 \mathrm{H}-\mathrm{CC} \\
7-10 \\
\mathrm{IIIc}\end{array}$ & & $\begin{array}{c}858 \mathrm{C} \\
12 \mathrm{X}-\mathrm{CC} \\
8-10 \\
\text { HIIc }\end{array}$ & & $\begin{array}{l}858 \mathrm{D} \\
2 \mathrm{H}-3 \\
34-36 \\
\mathrm{Vb}\end{array}$ & & & $\begin{array}{l}858 \mathrm{D} \\
2 \mathrm{H}-\mathrm{CC} \\
10-12 \\
\mathrm{Vb}\end{array}$ & & & & & $\begin{array}{c}85 \\
9 \mathrm{R} \\
9 \\
\mathrm{I}\end{array}$ & $\begin{array}{l}8 \mathrm{~F} \\
\mathrm{CC} \\
11 \\
\mathrm{~b}\end{array}$ & & \\
\hline $\begin{array}{l}\mathrm{SiO}_{2} \\
\mathrm{Al}_{2} \mathrm{O}_{3} \\
\mathrm{FeO} \\
\mathrm{CaO} \\
\mathrm{Na}_{2} \mathrm{O} \\
\mathrm{K}_{2} \mathrm{O} \\
\mathrm{BaO} \\
\text { Total }\end{array}$ & $\begin{array}{r}69.19 \\
19.30 \\
0.05 \\
0.05 \\
11.59 \\
0.04 \\
\text { nd } \\
100.21\end{array}$ & $\begin{array}{r}65.44 \\
22.41 \\
0.18 \\
3.53 \\
9.72 \\
0.13 \\
\text { nd } \\
101.41\end{array}$ & $\begin{array}{r}69.65 \\
19.85 \\
0.09 \\
0.32 \\
11.42 \\
0.10 \\
\text { nd } \\
101.43\end{array}$ & $\begin{array}{r}63.85 \\
18.47 \\
0.10 \\
0.00 \\
0.16 \\
15.54 \\
\text { nd } \\
98.13\end{array}$ & $\begin{array}{r}69.46 \\
19.58 \\
0.08 \\
0.03 \\
11.88 \\
0.00 \\
\text { nd } \\
101.02\end{array}$ & $\begin{array}{r}68.76 \\
20.24 \\
0.06 \\
0.39 \\
11.70 \\
0.17 \\
\text { nd } \\
101.31\end{array}$ & $\begin{array}{r}69.72 \\
19.67 \\
0.04 \\
0.19 \\
11.69 \\
0.08 \\
\text { nd } \\
101.38\end{array}$ & $\begin{array}{r}65.67 \\
19.30 \\
0.13 \\
0.06 \\
4.81 \\
11.12 \\
0.63 \\
101.72\end{array}$ & $\begin{array}{r}67.75 \\
19.78 \\
0.11 \\
0.43 \\
11.03 \\
0.10 \\
0.00 \\
99.20\end{array}$ & $\begin{array}{r}68.58 \\
19.71 \\
0.08 \\
0.11 \\
11.81 \\
0.05 \\
0.01 \\
100.34\end{array}$ & $\begin{array}{r}67.32 \\
20.55 \\
0.13 \\
0.59 \\
11.43 \\
0.12 \\
0.00 \\
100.14\end{array}$ & $\begin{array}{r}57.71 \\
24.75 \\
0.18 \\
6.79 \\
7.44 \\
0.29 \\
0.00 \\
97.16\end{array}$ & $\begin{array}{r}62.03 \\
24.54 \\
0.12 \\
5.34 \\
8.36 \\
0.40 \\
0.11 \\
100.90\end{array}$ & $\begin{array}{r}62.35 \\
24.37 \\
0.09 \\
5.34 \\
8.30 \\
0.40 \\
0.05 \\
100.90\end{array}$ & $\begin{array}{r}59.57 \\
24.00 \\
0.07 \\
5.44 \\
8.38 \\
0.15 \\
0.00 \\
97.62\end{array}$ & $\begin{array}{r}64.19 \\
22.67 \\
0.22 \\
3.37 \\
9.76 \\
0.13 \\
0.01 \\
100.34\end{array}$ & $\begin{array}{r}59.88 \\
26.04 \\
0.07 \\
7.31 \\
7.64 \\
0.04 \\
0.00 \\
100.98\end{array}$ & $\begin{array}{r}55.94 \\
27.58 \\
0.07 \\
10.22 \\
5.75 \\
0.02 \\
\text { nd } \\
99.58\end{array}$ & $\begin{array}{r}60.45 \\
25.72 \\
0.04 \\
7.40 \\
7.43 \\
0.09 \\
\text { nd } \\
101.14\end{array}$ \\
\hline $\begin{array}{l}\mathrm{Si} \\
\mathrm{Al} \\
\mathrm{Fe} \\
\mathrm{Ca} \\
\mathrm{Na} \\
\mathrm{K} \\
\mathrm{Ba}\end{array}$ & $\begin{array}{r}12.042 \\
3.961 \\
0.007 \\
0.009 \\
3.910 \\
0.008 \\
0.000\end{array}$ & $\begin{array}{r}11.384 \\
4.596 \\
0.025 \\
0.658 \\
3.279 \\
0.030 \\
0.000\end{array}$ & $\begin{array}{r}11.986 \\
4.026 \\
0.014 \\
0.060 \\
3.809 \\
0.021 \\
0.000\end{array}$ & $\begin{array}{r}11.982 \\
4.086 \\
0.016 \\
0.000 \\
0.059 \\
3.720 \\
0.000\end{array}$ & $\begin{array}{r}12.005 \\
3.990 \\
0.011 \\
0.005 \\
3.979 \\
0.000 \\
0.000\end{array}$ & $\begin{array}{r}11.879 \\
4.123 \\
0.008 \\
0.071 \\
3.920 \\
0.037 \\
0.000\end{array}$ & $\begin{array}{r}12.005 \\
3.993 \\
0.006 \\
0.034 \\
3.903 \\
0.017 \\
0.000\end{array}$ & $\begin{array}{r}11.830 \\
4.098 \\
0.020 \\
0.011 \\
1.681 \\
2.554 \\
0.045\end{array}$ & $\begin{array}{r}11.926 \\
4.104 \\
0.017 \\
0.081 \\
3.766 \\
0.023 \\
0.000\end{array}$ & $\begin{array}{r}11.948 \\
4.048 \\
0.012 \\
0.020 \\
3.989 \\
0.010 \\
0.001\end{array}$ & $\begin{array}{r}11.779 \\
4.240 \\
0.019 \\
0.111 \\
3.876 \\
0.027 \\
0.000\end{array}$ & $\begin{array}{r}10.613 \\
5.365 \\
0.028 \\
1.337 \\
2.652 \\
0.068 \\
0.000\end{array}$ & $\begin{array}{r}10.926 \\
5.096 \\
0.018 \\
1.008 \\
2.855 \\
0.089 \\
0.008\end{array}$ & $\begin{array}{r}10.968 \\
5.053 \\
0.013 \\
1.006 \\
2.831 \\
0.090 \\
0.003\end{array}$ & $\begin{array}{r}10.849 \\
5.154 \\
0.011 \\
1.062 \\
2.960 \\
0.035 \\
0.000\end{array}$ & $\begin{array}{r}11.299 \\
4.703 \\
0.032 \\
0.635 \\
3.332 \\
0.029 \\
0.000\end{array}$ & $\begin{array}{r}10.579 \\
5.423 \\
0.011 \\
1.384 \\
2.618 \\
0.008 \\
0.000\end{array}$ & $\begin{array}{r}10.099 \\
5.871 \\
0.010 \\
1.977 \\
2.012 \\
0.004 \\
0.000\end{array}$ & $\begin{array}{r}10.651 \\
5.343 \\
0.005 \\
1.398 \\
2.540 \\
0.020 \\
0.000\end{array}$ \\
\hline $\begin{array}{l}\mathrm{An} \\
\mathrm{Ab} \\
\mathrm{Or}\end{array}$ & $\begin{array}{r}0.23 \\
99.56 \\
0.20\end{array}$ & $\begin{array}{r}16.59 \\
82.67 \\
0.74\end{array}$ & $\begin{array}{r}1.53 \\
97.93 \\
0.54\end{array}$ & $\begin{array}{r}0.00 \\
1.56 \\
98.44\end{array}$ & $\begin{array}{r}0.12 \\
99.88 \\
0.00\end{array}$ & $\begin{array}{r}1.77 \\
97.31 \\
0.92\end{array}$ & $\begin{array}{r}0.86 \\
98.70 \\
0.43\end{array}$ & $\begin{array}{r}0.27 \\
39.58 \\
60.15\end{array}$ & $\begin{array}{r}2.09 \\
97.32 \\
0.59\end{array}$ & $\begin{array}{r}0.49 \\
99.25 \\
0.26\end{array}$ & $\begin{array}{r}2.76 \\
96.55 \\
0.68\end{array}$ & $\begin{array}{r}32.95 \\
65.38 \\
1.67\end{array}$ & $\begin{array}{r}25.51 \\
72.24 \\
2.25\end{array}$ & $\begin{array}{r}25.62 \\
72.09 \\
2.30\end{array}$ & $\begin{array}{r}26.18 \\
72.97 \\
0.85\end{array}$ & $\begin{array}{r}15.89 \\
83.39 \\
0.72\end{array}$ & $\begin{array}{r}34.51 \\
65.29 \\
0.21\end{array}$ & $\begin{array}{r}49.52 \\
50.39 \\
0.10\end{array}$ & $\begin{array}{r}35.32 \\
64.17 \\
0.51\end{array}$ \\
\hline
\end{tabular}




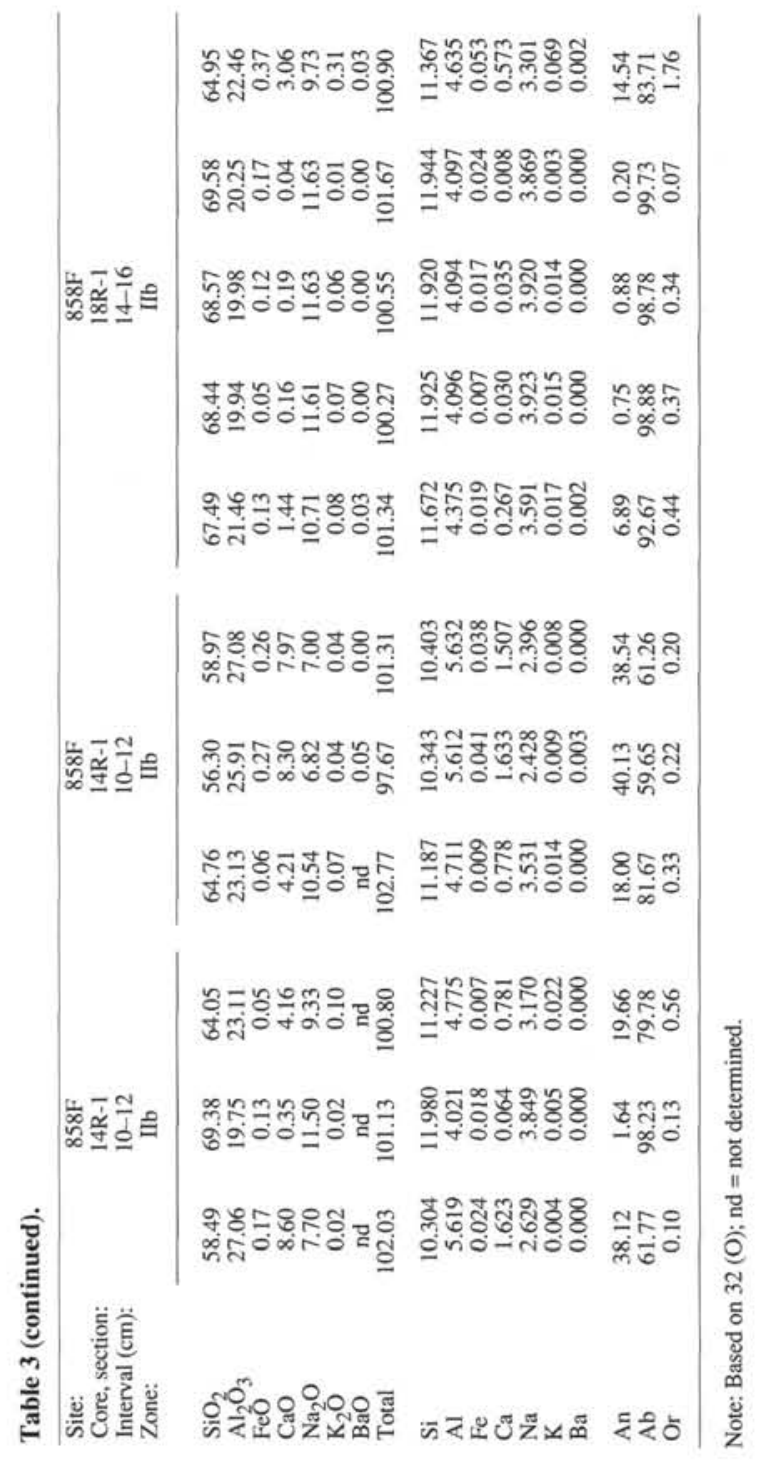

also occurs disseminated in sediments from 225 to $270 \mathrm{mbsf}$ in Hole 858 A.

Detrital quartz crystals host two-phase fluid inclusions below depths of $35.7 \mathrm{mbsf}$ in Hole 858A, $33 \mathrm{mbsf}$ in Hole $858 \mathrm{C}$ and $27 \mathrm{mbsf}$ in Hole $858 \mathrm{D}$ and indicate that quartz has been partially recrystallized and overgrown below these depths. Detrital K-feldspar is variably altered to sericite and chlorite below $16 \mathrm{mbsf}$ in Hole 858A, $21 \mathrm{mbsf}$ in Hole $858 \mathrm{C}$, and $2 \mathrm{mbsf}$ in Hole 858D. The degree of K-feldspar alteration increases to depths of $246 \mathrm{mbsf}$ in Hole 858A and $33 \mathrm{mbsf}$ in Hole $858 \mathrm{C}$, below which it is commonly completely replaced by sericite and chlorite. Detrital plagioclase is altered to albite at depths $>25$ mbsf in Hole $858 \mathrm{~A}$ and $>21 \mathrm{mbsf}$ in Hole $858 \mathrm{C}$ (Table 3; Fig. 12B). Epidote was observed in the uppermost 100 meters in Hole $858 \mathrm{~A}$ and throughout Holes $858 \mathrm{~B}$ and $858 \mathrm{C}$. Epidote forms up to $1-2 \mathrm{vol} \%$ and ranges up to $75 \mu \mathrm{m}$ in diameter (Table 12). An anhedral morphology and its concentration in silt and sand laminae indicate a detrital origin. Pyrite occurs finely disseminated throughout hemipelagic silty clay as framboids, euhedral to anhedral crystals, and crystal aggregates. Euhedral to subhedral pyrite occurs interstitially within turbiditic silt and sand and infills burrows and carbonate concretions. In Hole $858 \mathrm{~A}$, pyrite contents are generally $<1 \mathrm{vol} \%$ but range to $8 \mathrm{vol} \%$ in Holes $858 \mathrm{C}$ and $858 \mathrm{D}$. Framboidal pyrite decreases in abundance with increasing depth. Marcasite alteration of pyrite is generally rare (e.g., Sample 139-858A-5H-4, 27-30 cm hosts pyrite with marcasite cores). Pyrrhotite only rarely occurs as disseminated crystals up to $300 \mu \mathrm{m}$ in diameter and as small cores surrounded by pyrite. Sphalerite crystals up to $100 \mu \mathrm{m}$ occur locally disseminated in hemipelagic sediment in Hole 858D (Table 12; Fig. 8).

Clay minerals in Holes $858 \mathrm{~A}, 858 \mathrm{C}$, and $858 \mathrm{D}$ are variably recrystallized and altered to chlorite and illite, with common extinction angles. The clay minerals are composed of $\mathrm{Si}-\mathrm{Al}-\mathrm{Mg}-\mathrm{Fe}-\mathrm{K} \pm \mathrm{Na}$ and $\mathrm{Ca}$, and plot as an array subparallel to the $\mathrm{Al}-\mathrm{Mg}$ join on a $\mathrm{Fe}-\mathrm{Al}-\mathrm{Mg}$ ternary diagram (Table 8; Fig. 15F,G). The clays vary little in Fe-content but show a large range in Mg-content (Fig. 15G). In Holes 858A and $858 \mathrm{C}$, a general increase in the $\mathrm{Mg}$ content of clay minerals with depth is reflected in the bulk chemical compositions (Goodfellow and Peter, this volume).

Carbonate occurs as cement, concretions, and in veins in all holes at this site, and forms massive carbonate breccia in Hole 858C (Goodfellow and Peter, this volume). Carbonate cement is concentrated in silt and sand laminae, and carbonate concretions occur most commonly in turbidites. Carbonate concretions occur above $101 \mathrm{mbsf}$ in Hole 858A (Fig. 5), 40 mbsf in Hole 858C (Fig. 7), and $30 \mathrm{mbsf}$ in Hole 858D (Fig. 8; Table 12). Calcite crystals are also disseminated in hemipelagic sediment above 147 and below 207 mbsf in Hole $858 \mathrm{~A}$, above $9 \mathrm{mbsf}$ in Hole $858 \mathrm{~B}$, and above $40 \mathrm{mbsf}$ in Hole $858 \mathrm{C}$. A massive carbonate breccia cemented by calcite composed of crystals up to $1 \mathrm{~mm}$ in diameter occurs at $15 \mathrm{mbsf}$ in Hole 858C. Calcite is the predominant carbonate phase, although between 33 and 38 mbsf in Hole $858 \mathrm{C}$ and between 12 and 14.5 mbsf in Hole 858D, dolomite occurs with calcite (Table 11; Fig. 17B; Davis, Mottl, Fisher, et al., 1992).

\section{Zone IVb}

Zone IVb consists of hydrothermal clay, pyrite, and anhydrite. It occurs between 70 and 175 mbsf in Hole 858A (Fig. 5), between 11.5 and $24 \mathrm{mbsf}$ in Hole 858B (Fig. 6), between 17 and $68.5 \mathrm{mbsf}$ in Hole 858C (Fig. 7), and between 20 and 28 mbsf in Hole 858D (Fig. 8). Anhydrite occurs as disseminated crystals and crystal aggregates, veins, and concretions between $62.5 \mathrm{mbsf}$ and $256 \mathrm{mbsf}$ in Hole $858 \mathrm{~A}, 11$ and $38 \mathrm{mbsf}$ in Hole 858B, 37 and $68 \mathrm{mbsf}$ in Hole 858C, and 2 and 28 mbsf in Hole 858D (Davis, Mottl, Fisher, et al., 1992; Table 12; Pl. 4, Figs. 1 and 2). In Hole $858 \mathrm{~F}$, veins and vugs of anhydrite occur between 110 and $170 \mathrm{mbsf}$ and anhydrite concretions and vugs occur between 170 and 200 mbsf (Davis, Mottl, Fisher, et al., 1992). Disseminated anhydrite laths comprise 1-2 vol\% and 
Table 4. Electron microprobe data for epidote in unaltered and hydrothermally altered hemipelagic and turbiditic sediment, Leg 139.

\begin{tabular}{|c|c|c|c|c|c|c|c|c|c|c|c|c|c|c|c|c|c|c|c|}
\hline $\begin{array}{l}\text { Site: } \\
\text { Core, section: } \\
\text { Interval }(\mathrm{cm}): \\
\text { Zone: } \\
\text { Type: }\end{array}$ & & $\begin{array}{r}8 \\
1 \\
11\end{array}$ & $\begin{array}{l}5 \mathrm{C} \\
\mathrm{R}-1 \\
-119 \\
\text { A } \\
\text { et }\end{array}$ & & & $\begin{array}{l}856 \mathrm{~A} \\
4 \mathrm{H}-6 \\
55-59 \\
\text { IVa } \\
\text { det }\end{array}$ & & & $\begin{array}{c}856 \mathrm{~A} \\
6 \mathrm{H}-3 \\
103-107 \\
1 \mathrm{Va} \\
\text { det }\end{array}$ & & $\begin{array}{l}8 \\
6 \\
9 \\
1\end{array}$ & & & & & & & $\begin{array}{l}857 \mathrm{~A} \\
6 \mathrm{H}-5 \\
89-93 \\
\text { UA } \\
\operatorname{det}\end{array}$ & \\
\hline $\mathrm{SiO}_{2}$ & 37.34 & 38.32 & 37.87 & 36.20 & 38.17 & 38.44 & 37.80 & 37.75 & 39.99 & 38.30 & 38.08 & 38.00 & 38.72 & 36.98 & 37.87 & 36.46 & 37.41 & 37.35 & 38.68 \\
\hline $\mathrm{TiO}_{2}^{2}$ & 0.03 & 0.09 & 0.22 & 0.07 & 0.12 & 0.20 & 0.09 & 0.08 & 0.12 & 0.04 & 0.10 & 0.08 & 0.26 & 0.12 & 0.01 & 0.21 & 0.12 & 0.05 & 0.08 \\
\hline $\mathrm{Al}_{2} \mathrm{O}_{3}$ & 22.29 & 20.63 & 24.64 & 19.05 & 24.25 & 23.75 & 22.17 & 23.13 & 22.29 & 27.17 & 24.68 & 24.99 & 29.04 & 22.71 & 23.09 & 22.39 & 21.27 & 22.46 & 24.30 \\
\hline $\mathrm{Fe}_{2} \mathrm{O}_{3}$ & 13.21 & 11.56 & 10.63 & 17.33 & 12.15 & 11.21 & 13.39 & 13.56 & 12.45 & 7.39 & 10.74 & 11.11 & 5.28 & 13.08 & 12.21 & 15.18 & 11.16 & 14.13 & 10.27 \\
\hline $\mathrm{MnO}^{3}$ & 0.06 & 0.17 & 0.25 & 0.09 & 0.16 & 0.09 & 0.10 & 0.31 & 0.13 & 0.22 & 0.25 & 0.21 & 0.27 & 0.17 & 0.17 & 0.44 & 0.07 & 0.91 & 0.07 \\
\hline $\mathrm{MgO}$ & 0.00 & 0.18 & 0.06 & 0.00 & 0.05 & 0.05 & 0.00 & 0.00 & 0.28 & 0.00 & 0.05 & 0.07 & 0.10 & 0.05 & 0.01 & 0.00 & 0.00 & 0.01 & 0.02 \\
\hline $\mathrm{CaO}$ & 23.31 & 21.80 & 23.30 & 20.82 & 23.47 & 23.26 & 23.31 & 23.16 & 21.91 & 23.43 & 23.13 & 23.46 & 23.97 & 22.85 & 23.03 & 22.69 & 23.19 & 21.94 & 23.61 \\
\hline $\mathrm{Na}_{2} \mathrm{O}$ & 0.00 & 0.11 & 0.06 & 0.01 & 0.01 & 0.12 & 0.00 & 0.00 & 0.05 & 0.06 & 0.02 & 0.02 & 0.00 & 0.00 & 0.00 & 0.02 & 0.03 & 0.01 & 0.03 \\
\hline $\mathrm{K}_{2} \mathrm{O}$ & 0.04 & 0.02 & 0.01 & 0.02 & 0.01 & 0.02 & 0.01 & 0.00 & 0.01 & 0.05 & 0.04 & 0.02 & 0.02 & 0.03 & 0.02 & 0.05 & 0.00 & 0.01 & 0.01 \\
\hline $\mathrm{Cr}_{2} \mathrm{O}_{3}$ & 0.01 & 0.04 & 0.00 & 0.08 & 0.03 & 0.39 & 0.04 & 0.00 & 0.00 & 0.00 & 0.00 & 0.00 & 0.11 & 0.00 & 0.02 & 0.03 & 0.00 & 0.00 & 0.00 \\
\hline $\mathrm{ZnO}$ & 0.00 & 0.00 & 0.00 & 0.03 & 0.05 & 0.00 & 0.06 & 0.02 & 0.11 & 0.03 & 0.00 & 0.00 & 0.03 & 0.07 & 0.00 & 0.14 & 0.04 & 0.00 & 0.02 \\
\hline Total & 96.29 & 92.93 & 97.03 & 93.69 & 98.47 & 97.53 & 96.95 & 98.00 & 97.34 & 96.68 & 97.09 & 97.95 & 97.79 & 96.05 & 96.41 & 97.61 & 93.30 & 96.85 & 97.07 \\
\hline $\mathrm{Si}$ & 3.028 & 3.212 & 3.016 & 3.072 & 3.011 & 3.055 & 3.048 & 3.009 & 3.202 & 3.022 & 3.032 & 2.999 & 2.998 & 3.004 & 3.056 & 2.936 & 3.119 & 3.024 & 3.077 \\
\hline $\mathrm{Ti}$ & 0.002 & 0.005 & 0.013 & 0.004 & 0.007 & 0.012 & 0.005 & 0.004 & 0.007 & 0.003 & 0.006 & 0.004 & 0.015 & 0.007 & 0.001 & 0.013 & 0.007 & 0.003 & 0.005 \\
\hline Al & 2.130 & 2.039 & 2.313 & 1.906 & 2.255 & 2.225 & 2.107 & 2.173 & 2.104 & 2.527 & 2.317 & 2.326 & 2.651 & 2.175 & 2.196 & 2.126 & 2.091 & 2.143 & 2.279 \\
\hline $\mathrm{Fe}$ & 0.806 & 0.729 & 0.637 & 1.107 & 0.721 & 0.671 & 0.812 & 0.813 & 0.750 & 0.439 & 0.643 & 0.660 & 0.307 & 0.800 & 0.741 & 0.920 & 0.700 & 0.861 & 0.615 \\
\hline $\mathrm{Mn}$ & 0.004 & 0.012 & 0.017 & 0.007 & 0.011 & 0.006 & 0.007 & 0.021 & 0.009 & 0.015 & 0.017 & 0.014 & 0.018 & 0.012 & 0.011 & 0.030 & 0.005 & 0.062 & 0.005 \\
\hline $\mathrm{Mg}$ & 0.000 & 0.022 & 0.007 & $\begin{array}{l}0.000 \\
0.000\end{array}$ & 0.005 & 0.006 & 0.000 & 0.000 & 0.034 & 0.000 & 0.005 & 0.008 & 0.011 & 0.006 & 0.001 & 0.000 & 0.000 & 0.001 & 0.002 \\
\hline $\mathrm{Ca}$ & 2.025 & $\begin{array}{l}0.022 \\
1.958\end{array}$ & 1.988 & $\begin{array}{l}1.894 \\
\end{array}$ & 1.983 & 1.981 & 2.014 & 1.978 & $\begin{array}{l}1.879 \\
\end{array}$ & 1.980 & 1.973 & $\begin{array}{l}0.900 \\
1.984\end{array}$ & 1.989 & 1.989 & 1.991 & $\begin{array}{l}1.957 \\
\end{array}$ & 2.071 & 1.903 & 2.013 \\
\hline $\mathrm{Na}$ & 0.000 & 0.018 & 0.010 & 0.001 & 0.001 & 0.018 & 0.000 & 0.000 & 0.007 & 0.008 & 0.002 & 0.003 & 0.000 & 0.000 & 0.000 & 0.003 & 0.004 & 0.002 & 0.004 \\
\hline $\mathrm{K}$ & 0.004 & 0.002 & 0.001 & 0.002 & 0.001 & 0.002 & 0.001 & 0.000 & 0.001 & 0.005 & 0.004 & 0.002 & 0.002 & 0.003 & 0.002 & 0.005 & 0.000 & 0.001 & 0.001 \\
\hline $\mathrm{Cr}$ & 0.001 & 0.003 & 0.000 & 0.006 & 0.002 & 0.025 & 0.002 & 0.000 & 0.000 & 0.000 & 0.000 & 0.000 & 0.007 & 0.000 & 0.001 & 0.002 & 0.000 & 0.000 & 0.000 \\
\hline $\mathrm{Zn}$ & 0.000 & 0.000 & 0.000 & 0.002 & 0.003 & 0.000 & 0.003 & 0.001 & 0.006 & 0.002 & 0.000 & 0.000 & 0.002 & 0.004 & 0.000 & 0.008 & 0.003 & 0.000 & 0.001 \\
\hline
\end{tabular}

Table 4 (continued).

\begin{tabular}{|c|c|c|c|c|c|c|c|c|c|c|c|c|c|c|c|c|c|c|}
\hline $\begin{array}{l}\text { Site: } \\
\text { Core, section: } \\
\text { Interval }(\mathrm{cm}) \text { : } \\
\text { Zone: } \\
\text { Type: }\end{array}$ & $\begin{array}{c}857 \mathrm{C} \\
30 \mathrm{R}-1 \\
116-120 \\
\text { IIIc } \\
\text { det }\end{array}$ & & & $\begin{array}{c}857 \mathrm{D} \\
5 \mathrm{R}-1 \\
26-28 \\
\text { IIc } \\
\text { auth }\end{array}$ & & & $\begin{array}{c}857 \mathrm{D} \\
6 \mathrm{R}-1 \\
20-22 \\
\text { Ic } \\
\text { auth }\end{array}$ & & $\begin{array}{l}7 \mathrm{D} \\
-1 \\
-22 \\
\mathrm{c} \\
\text { th }\end{array}$ & & & $\begin{array}{l}857 \mathrm{D} \\
\text { 17R-2 } \\
53-55 \\
\text { II } \\
\text { auth }\end{array}$ & & & & $\begin{array}{r}85 \\
215 \\
14- \\
\text { II } \\
\text { au }\end{array}$ & & \\
\hline $\mathrm{SiO}_{2}$ & 38.77 & 38.20 & 37.99 & 38.18 & 37.57 & 37.75 & 38.11 & 38.81 & 38.69 & 37.60 & 38.56 & 37.87 & 36.70 & 37.16 & 38.54 & 37.25 & 37.99 & 37.51 \\
\hline $\mathrm{TiO}_{2}^{2}$ & 0.12 & 0.07 & 0.38 & 0.05 & 0.16 & nd & nd & 0.11 & 0.02 & 0.01 & 0.14 & 0.09 & 0.09 & nd & 0.09 & 0.10 & 0.16 & 0.11 \\
\hline $\mathrm{Al}_{2} \mathrm{O}_{3}$ & 27.03 & 24.40 & 25.06 & 27.22 & 21.55 & 24.30 & 26.60 & 26.66 & 27.77 & 21.48 & 25.76 & 24.82 & 25.13 & 26.47 & 27.54 & 24.01 & 26.30 & 24.44 \\
\hline $\mathrm{Fe}_{2} \mathrm{O}_{3}$ & 7.66 & 6.80 & 9.97 & 6.43 & 7.43 & 10.90 & 9.30 & 7.35 & 5.64 & 14.98 & 6.46 & 10.23 & 11.18 & 8.46 & 6.28 & 11.24 & 11.14 & 10.60 \\
\hline $\mathrm{MnO}^{3}$ & 0.16 & 0.15 & 0.02 & 0.28 & 0.23 & nd & nd & 0.12 & 0.12 & 0.51 & 0.16 & 0.23 & 0.40 & nd & 0.18 & 0.11 & 0.37 & 0.03 \\
\hline $\mathrm{MgO}$ & 0.00 & 0.04 & 0.07 & 0.03 & 0.26 & nd & nd & 0.02 & 0.04 & 0.04 & 0.03 & 0.66 & 0.00 & nd & 0.11 & 0.16 & 0.00 & 0.02 \\
\hline $\mathrm{CaO}$ & 24.04 & 22.91 & 23.56 & 23.94 & 23.02 & 23.23 & 23.70 & 24.15 & 24.12 & 22.50 & 23.51 & 22.85 & 22.56 & 23.50 & 23.61 & 23.00 & 23.02 & 23.50 \\
\hline $\mathrm{Na}_{2} \mathrm{O}$ & 0.03 & 0.08 & 0.05 & 0.04 & 2.32 & 0.08 & 0.00 & 0.01 & 0.00 & 0.00 & 0.00 & 0.01 & 0.00 & 0.01 & 0.06 & 0.08 & 0.03 & 0.01 \\
\hline $\mathrm{K}_{2} \mathrm{O}$ & 0.04 & 0.02 & 0.01 & 0.01 & 0.01 & 0.01 & 0.00 & 0.00 & 0.01 & 0.01 & 0.02 & 0.00 & 0.00 & 0.02 & 0.02 & 0.00 & 0.00 & 0.03 \\
\hline $\mathrm{Cr}_{2}^{2} \mathrm{O}_{3}$ & 0.00 & 0.03 & 0.02 & 0.00 & 1.16 & nd & nd & 0.00 & 0.02 & 0.01 & 0.00 & 0.00 & 0.02 & nd & 0.01 & 0.01 & 0.07 & 0.00 \\
\hline $\mathrm{ZnO}^{\circ}$ & 0.14 & 0.16 & 0.07 & 0.00 & 0.08 & nd & nd & 0.04 & 0.00 & 0.04 & 0.00 & 0.07 & 0.00 & nd & 0.05 & 0.00 & 0.00 & 0.00 \\
\hline Total & 97.98 & 92.86 & 97.20 & 96.19 & 93.78 & 96.25 & 97.70 & 97.27 & 96.42 & 97.19 & 94.63 & 96.82 & 96.08 & 95.61 & 96.48 & 95.95 & 99.08 & 96.25 \\
\hline $\mathrm{Si}$ & 3.023 & 3.144 & 3.013 & 3.019 & 3.024 & 3.030 & 2.993 & 3.047 & 3.043 & 3.043 & 3.107 & 3.011 & 2.955 & 2.975 & 3.035 & 3.003 & 2.962 & 3.011 \\
\hline $\mathrm{Ti}$ & 0.007 & 0.004 & 0.022 & 0.003 & 0.010 & 0.000 & 0.000 & 0.006 & 0.001 & 0.001 & 0.008 & 0.005 & 0.006 & 0.000 & 0.005 & 0.006 & 0.010 & 0.007 \\
\hline $\mathrm{Al}$ & 2.485 & 2.368 & 2.343 & 2.537 & 2.045 & 2.300 & 2.463 & 2.468 & 2.575 & 2.049 & 2.447 & 2.327 & 2.386 & 2.498 & 2.556 & 2.282 & 2.418 & 2.313 \\
\hline $\mathrm{Fe}$ & 0.449 & 0.421 & 0.595 & 0.383 & 0.450 & 0.658 & 0.549 & 0.434 & 0.334 & 0.912 & 0.392 & 0.612 & 0.678 & 0.509 & 0.372 & 0.682 & 0.654 & 0.640 \\
\hline $\mathrm{Mn}$ & 0.011 & 0.010 & 0.001 & 0.019 & 0.015 & 0.000 & 0.000 & 0.008 & 0.008 & 0.035 & 0.011 & 0.015 & 0.027 & 0.000 & 0.012 & 0.008 & 0.024 & 0.002 \\
\hline $\mathrm{Mg}$ & 0.000 & 0.005 & 0.009 & 0.004 & 0.031 & 0.000 & 0.000 & 0.003 & 0.005 & 0.004 & 0.003 & 0.078 & 0.000 & 0.000 & 0.013 & 0.019 & 0.000 & 0.002 \\
\hline $\mathrm{Ca}$ & 2.009 & 2.021 & 2.002 & 2.029 & 1.985 & 1.998 & 1.995 & 2.031 & 2.033 & 1.951 & 2.030 & $\begin{array}{l}1.947\end{array}$ & $\begin{array}{l}1.947\end{array}$ & 2.015 & 1.992 & 1.987 & 1.923 & 2.021 \\
\hline $\mathrm{Na}$ & 0.005 & 0.012 & 0.008 & 0.006 & 0.362 & 0.013 & 0.000 & 0.001 & 0.000 & 0.000 & 0.001 & 0.001 & 0.000 & 0.001 & 0.008 & 0.013 & 0.004 & 0.002 \\
\hline K & 0.003 & 0.002 & 0.001 & 0.001 & 0.001 & 0.001 & 0.000 & 0.000 & 0.001 & 0.001 & 0.002 & 0.000 & 0.000 & 0.002 & 0.002 & 0.000 & 0.000 & 0.003 \\
\hline $\mathrm{Cr}$ & 0.000 & 0.002 & 0.001 & 0.000 & 0.074 & 0.000 & 0.000 & 0.000 & 0.001 & 0.000 & 0.000 & 0.000 & 0.001 & 0.000 & 0.001 & 0.001 & 0.004 & 0.000 \\
\hline $\mathrm{Zn}$ & 0.008 & 0.010 & 0.004 & 0.000 & 0.005 & 0.000 & 0.000 & 0.002 & 0.000 & 0.002 & 0.000 & 0.004 & 0.000 & 0.000 & 0.003 & 0.000 & 0.000 & 0.000 \\
\hline
\end{tabular}




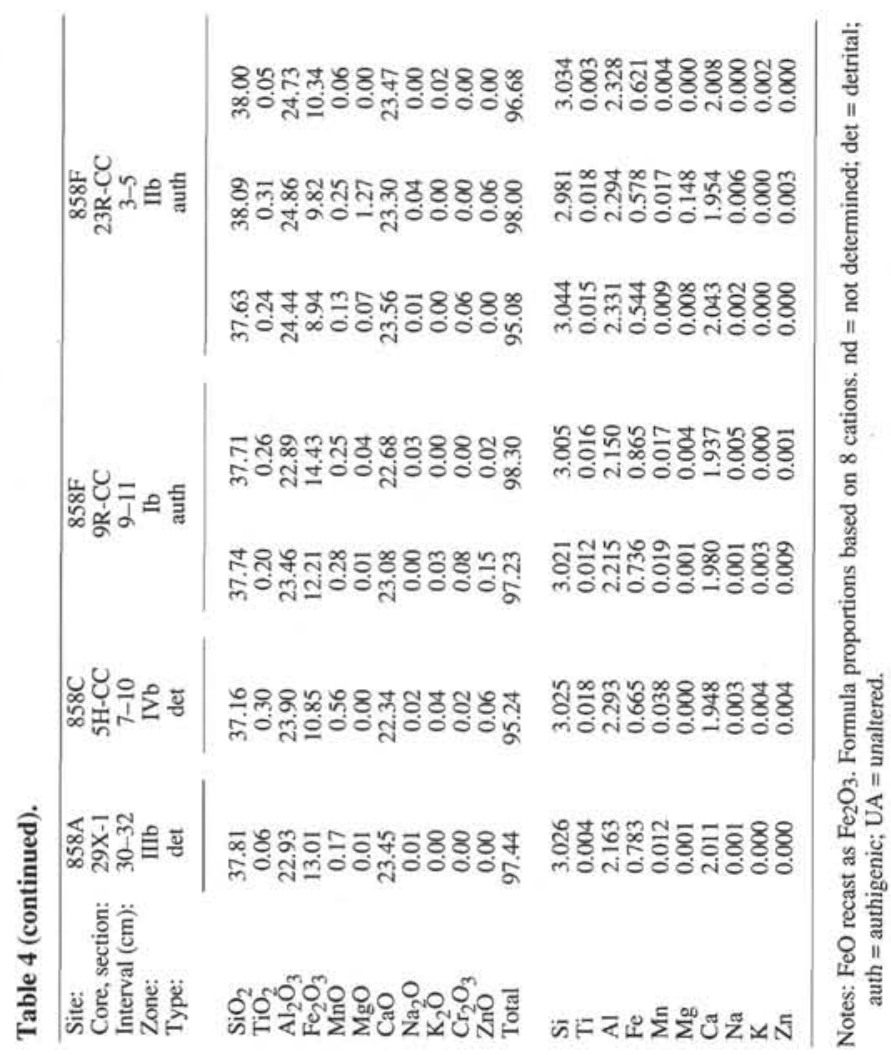

range up to $4 \mathrm{~mm}$ in length. In Hole $858 \mathrm{C}$, anhydrite crystals are corroded and broken at $68 \mathrm{mbsf}$, suggesting reaction with hydrothermal fluids. Barite is rare and was observed only in Hole 858B (Sample 139-856B-2H-6, 69-71 cm), where it forms rosettes composed of crystals up to $200 \mu \mathrm{m}$.

\section{Zone IIIb}

This zone consists of albite-chlorite-pyrite and occurs between 175 and $320 \mathrm{mbsf}$ in Hole 858A (Fig. 5), and between 33 and $92 \mathrm{mbsf}$ in Hole $858 \mathrm{C}$ (Fig. 7). Anhydrite veins cut this zone locally. The alteration mineralogy is similar to the previous two zones (i.e., overgrowth and recrystallization of quartz, albitization of plagioclase, alteration of detrital K-feldspar to sericite and chlorite, and recrystallization of clays to chlorite and illite) except that carbonate and anhydrite are generally absent. Chlorite $(\mathrm{Fe} / \mathrm{Fe}+\mathrm{Mg}=0.35-0.59$; Table 7) is more dominant than in previous zones and illite more subordinate based on XRD (Table 2) and lower $\mathrm{K}_{2} \mathrm{O}$ contents (Goodfellow and Peter, this volume).

\section{Zone IIb}

This zone only occurs in Hole $858 \mathrm{~F}$ between 120 and $142 \mathrm{mbsf}$ and between 173 and 249 mbsf (Fig. 8) and is characterized by lithified, brecciated, fractured, and veined hemipelagic and turbiditic sediments. These sediments are altered to quartz-epidote-chlorite and crosscut locally by anhydrite-pyrite-chalcopyrite veins.

The clay fraction is dominated by chlorite (Tables 2 and 7) and Fe-Mg-Al silicates (Table 8). Authigenic Fe-Mg chlorite also occurs interstitial to vein wairakite (Sample 139-858F-2R-CC, 7-10 cm and $139-858 \mathrm{~F}-18 \mathrm{R}-1,14-16 \mathrm{~cm})$. The alteration of detrital micas to chlorite in Hole $858 \mathrm{~F}$ is consistent with low $\mathrm{K}_{2} \mathrm{O}$ contents of bulk sediments (Goodfellow and Peter, this volume). Epidote is a common phase in Hole $858 \mathrm{~F}$ and forms up to $20 \mathrm{vol} \%$ (Table 12). This epidote consists of granular masses and subhedral to anhedral crystals that are disseminated in both hemipelagic silty clay and turbiditic sediment. The authigenic epidote is generally more $\mathrm{Al}$-rich and $\mathrm{Fe}$-poor than detrital epidote (Table 4; Fig. 13). Authigenic sphene occurs as subhedral to anhedral crystals and xenoblastic aggregates.

\section{Zone $\mathrm{Ib}$}

This zone represents the core of hydrothermal fluid upflow at AAV and consists of fractured, veined, and brecciated lithified hemipelagic and turbiditic sediment. These sediments have been altered to the mineral assemblage quartz-wairakite-epidote-pyrite \pm sphene \pm plagioclase between 28 and 120 mbsf and between 142 and 173 mbsf.

Quartz and wairakite infill euhedral anhydrite(?) molds (Sample $139-858 \mathrm{~F}-2 \mathrm{R}-\mathrm{CC}, 7-10 \mathrm{~cm}$ ) and voids and form veins in Holes $858 \mathrm{C}$, $858 \mathrm{D}$, and $858 \mathrm{~F}$. Wairakite locally replaces the matrix of sediments in Holes $858 \mathrm{C}$ and $858 \mathrm{~F}$. Veins are wairakite-quartz, wairakite-quartzepidote, and wairakite-sphalerite. Elongate euhedral crystals of hydrothermal quartz with single and double terminations occur with wairakite in veins in Hole $858 \mathrm{~F}$. Wairakite crystals are commonly twinned, equant, subhedral to anhedral, range to up to $2 \mathrm{~mm}$ in diameter, and host abundant fluid inclusions (Peter et al., this volume). Matrix wairakite forms up to $35 \mathrm{vol} \%$ of the sediment (Sample 139$858 \mathrm{~F}-9 \mathrm{R}-\mathrm{CC}, 9-11 \mathrm{~cm}$ ) and is typically anhedral due partly to the corrosion of crystal surfaces by hydrothermal fluids. Minor Na substitutes for $\mathrm{Ca}$ in wairakite $(\mathrm{Ca} / \mathrm{Ca}+\mathrm{Na}$ ratios range from 0.871 to 0.967 ; Table 13). K-feldspar was not observed in Hole 858F. Plagioclase compositions in Holes $858 \mathrm{D}$ and $858 \mathrm{~F}$ are highly variable, with the most albite-rich plagioclase occurring above 20 mbsf in Hole $858 \mathrm{D}$ and below $180 \mathrm{mbsf}$ in Hole 858F. Plagioclase feldspar at $18.9 \mathrm{mbsf}$ in Hole $858 \mathrm{D}$ contains up to An 33. The anorthite content increases downhole, reaching a maximum of An 49.2 at 95 mbsf (Sample 139-858F-9R-CC, 9-11 cm; Table 3; Fig. 12B). The plagioclase in this sample is commonly embayed and displays albite twinning (Pl. 4, Fig. 3). The anorthite content of hydrothermal plagioclase decreases 
Table 5. Summary of alteration zones for Sites 856,858 , and 857 .

\begin{tabular}{|c|c|c|c|c|}
\hline Alteration zones & Hole & $\begin{array}{l}\text { Depth } \\
\text { (mbsf) }\end{array}$ & Alteration mineralogy & Comments \\
\hline \multicolumn{5}{|l|}{ Site 856 (Bent Hill) } \\
\hline IVa (Ca-II-Py) & $856 \mathrm{~A}$ & $17-86$ & $\begin{array}{l}\text { Qz - fluid inclusions and irregular boundaries; Plag - altered to albite; K-spar } \\
\text { altered to Ser }+ \text { Ch; clays altered to Ch }+\mathrm{Il} \text {; Ca concretions + cement; Py } \\
\text { replaces framboidal Py; Mag - partly altered to Py }\end{array}$ & Not present in Hole $856 \mathrm{~B}$ due to mass wasting. \\
\hline IIIa (An-II-Py) & $\begin{array}{l}856 \mathrm{~A} \\
856 \mathrm{~B}\end{array}$ & $\begin{array}{l}60-112 \\
30-70\end{array}$ & $\begin{array}{l}\text { Clay mineral grain size greater than in Zone IVa; } \mathrm{An} \text { - molds and } \mathrm{SO}_{4}^{2-} \text { in pore } \\
\text { water, rare } \mathrm{Cp}+\mathrm{Po}\end{array}$ & $\begin{array}{l}\text { Anhydrite largely removed by retrograde reaction. Sediments fractured and brecciated in } \\
\text { Hole } 856 \mathrm{~B} \text {. }\end{array}$ \\
\hline Па (Ab-Ch-Ms-Py) & $856 \mathrm{~B}$ & $70-110$ & $\begin{array}{l}\text { Qz - ragged/diffuse boundaries, rare euhedral terminations; Plag - altered to } \\
\text { albite; clay minerals coarse grained } \mathrm{Ch}+\mathrm{Ms} ; \mathrm{Ru} \text { a common accessory }\end{array}$ & Increasing induration with depth. \\
\hline Ial (Qz-Ch-Ms-Ru-Cp-Po) & $856 \mathrm{~B}$ & $110-117.5$ & $\begin{array}{l}\text { Qz - anhedral to hexagonal, abundant fluid inclusions; } \mathrm{Fs} \text { - all removed below } \\
110 \text { mbsf: } \mathrm{Ch} \text { - Fe-rich: } \mathrm{Ch}+\mathrm{Ms} \text { coarse gained (to } 25 \mathrm{~m}) ; \mathrm{Cp} \pm \mathrm{Py} \pm \mathrm{Po} \text { veins }\end{array}$ & $\begin{array}{l}\text { Indurated and silicified hemipelagic and turbiditic sediments. Coarse grained compared } \\
\text { to previous zones. }\end{array}$ \\
\hline Ia2 (Qz-Ch-Sm-Fs) & $856 \mathrm{~B}$ & $117.5-118$ & $\begin{array}{l}\text { Minor Fs; Sm - identified by XRD; Ch - Mg-rich near Cp veins; } \mathrm{Ba} \text { - associated } \\
\text { with veins }\end{array}$ & Narrow subzone adjacent to mafic sill at the base of Hole 856B. \\
\hline Massive sulfide & $\begin{array}{l}856 \mathrm{~B} \\
856 \mathrm{D}-\mathrm{H}\end{array}$ & $\begin{array}{l}18.4-23.2 \\
\text { throughout }\end{array}$ & Silicates - Ta, Ser, Ch, Sa(Ver?); Carbonates - Do, Ca, Ma & $\begin{array}{l}\text { Clastic sulfide zone in } 856 \mathrm{~B} \text { shed from adjacent sulfide mound. Ch and Sa(Ver?) only } \\
\text { present in veined sediment in Hole } 856 \mathrm{H} \text {. }\end{array}$ \\
\hline \multicolumn{5}{|c|}{ Site 858 (Area of Active Venting) } \\
\hline $\mathrm{VIb}(\mathrm{Sa}-\mathrm{Ta}-\mathrm{Py})$ & $858 \mathrm{~B}$ & $24-38$ & $\mathrm{Sa}(\mathrm{Ch}+\mathrm{Ver} ?)$ and $\mathrm{Ta}$ zone -bulk sediments up to $30 \mathrm{wt} \% \mathrm{MgO}$ & Below $24 \mathrm{mbsf}$, sediment is brecciated, cut by $\mathrm{Qz}+$ An veins. \\
\hline $\mathrm{Vb}(\mathrm{Ca}-\mathrm{II}-\mathrm{Py})$ & $\begin{array}{l}858 \mathrm{~A} \\
858 \mathrm{C} \\
858 \mathrm{D}\end{array}$ & $\begin{array}{r}15-80 \\
2-17 \\
0-20\end{array}$ & $\begin{array}{l}\text { Qz - partially overgrown and recrystallized, minor fluid inclusions; K-feld - } \\
\text { partly altered to Ser + Ch; Plag - partly to completely altered to albite; clays } \\
\text { variably recrystallized to } \mathrm{Il}+\mathrm{Ch} ; \mathrm{Ca} \text { - cement and concretions; Do - narrow } \\
\text { bands in Holes } 858 \mathrm{C} \text { and } 858 \mathrm{D} ; \mathrm{Py} \text { - recrystallized framboidal and alteration of } \\
\text { Mag, rare Mr, Po, Sp }\end{array}$ & $\begin{array}{l}\text { Sediment weakly to moderately indurated, olive grey to medium grey, commonly } \\
\text { bioturbated. Hole } 858 \mathrm{C} \text { brecciated below } 17 \text { mbsf. }\end{array}$ \\
\hline IVb (An-II-Py) & $\begin{array}{l}858 \mathrm{~A} \\
858 \mathrm{~B} \\
858 \mathrm{C} \\
858 \mathrm{D}\end{array}$ & $\begin{array}{c}70-175 \\
11.5-24 \\
17-68.5 \\
20-28\end{array}$ & An - nodules, lath crystals in sediment and crosscutting veins & $\begin{array}{l}\text { Sediment moderately indurated, medium grey, locally bioturbated. Fractured and } \\
\text { brecciated in Hole 858C. }\end{array}$ \\
\hline $111 \mathrm{lb}(\mathrm{Ab}-\mathrm{Ch}-11-\mathrm{Py})$ & $\begin{array}{l}858 \mathrm{~A} \\
858 \mathrm{C}\end{array}$ & $\begin{array}{c}20-20 \\
175-320\end{array}$ & $\begin{array}{l}\text { Qz - overgrown and recrystallized; Plag - altered to albite; clays recrystallized to } \\
\text { Ch } \pm \pi \text {. Ca a minor component of Hole } 858 \mathrm{~A} \text { between } 225 \text { and } 270 \text { mbsf }\end{array}$ & Moderately indurated to indurated sediment. \\
\hline $\mathrm{Ilb}$ (Qz-Ep-Ch) & $858 \mathrm{~F}$ & $\begin{array}{l}120-142 \\
173-249\end{array}$ & $\begin{array}{l}\text { Ep - hydrothermal epidote up to } 20 \text { vol\%; clays recrystallized to } \mathrm{Ch} ; \mathrm{Sn} \text { - } \\
\text { common authigenic accessory }\end{array}$ & Sediments indurated and brecciated. This zone overlaps with Zone Ib. \\
\hline $\mathrm{Ib}(\mathrm{Qz}$-Wa-Ep-Py-Sp) & $858 \mathrm{~F}$ & $\begin{array}{r}28-120 \\
142-173\end{array}$ & $\begin{array}{l}\text { Wa - vein phase, rarely as matrix replacement after Fs?; Qz - common vein } \\
\text { phase; rare hydrothermal plag; An - veins and vugs (retrograde phase?); Py } \pm \\
\text { Sp in veins }\end{array}$ & Sediments indurated and brecciated. \\
\hline \multicolumn{5}{|l|}{ Site 857 (Reaction Zone) } \\
\hline IVc (Ca-II-Py) & $857 \mathrm{C}$ & $70-300$ & $\begin{array}{l}\text { Clays - recrystallized to } \mathrm{Il}+\mathrm{Ch}( \pm \mathrm{Sm} \text { ); } \mathrm{Ca} \text { - concretions and cement (Do occurs } \\
\text { from } 85-105 \mathrm{mbsf}) ; \mathrm{Py} \text { - disseminated; } \mathrm{Po} \pm \mathrm{Py}+\mathrm{Sp} \text { veins; } \mathrm{Mt} \text { - altered to } \mathrm{Py}\end{array}$ & $\begin{array}{l}\text { Weakly to moderately indurated hemipelagic and turbiditic sediments. Commonly } \\
\text { bioturbated. }\end{array}$ \\
\hline IIIc (Ab-Ch-Py) & $857 \mathrm{C}$ & $250-450$ & $\begin{array}{l}\text { Qz - overgrown, partially recrystallized; Plag - altered to albite; K-spar - variably } \\
\text { altered to Ser }+ \text { Ch }\end{array}$ & Moderately indurated. \\
\hline IIc (Qz-Ch-Ep-Py) & $857 \mathrm{C} / \mathrm{D}$ & $450-936$ & $\begin{array}{l}\text { Ep - up to } 30 \text { vol\%; Detrital micas rare to absent below } 600 \mathrm{mbsf} \text {; } \mathrm{Sn} \text { - common } \\
\text { authigenic accessory }\end{array}$ & Hemipelagic and turbiditic sediments indurated, interbedded with mafic sills. \\
\hline Ic (Qz-Wa-Ep) & $\begin{array}{l}857 \mathrm{C} / \mathrm{D} \\
\text { (veins) }\end{array}$ & $522-736$ & $\mathrm{Qz}$ - commonly euhedral; Wa - common fluid inclusions & Veins crosscutting sediments and mafic sills. \\
\hline
\end{tabular}

Note: $\mathrm{Qz}=$ quartz; $\mathrm{Fs}=$ feldspar; $\mathrm{Plag}=$ plagioclase; $\mathrm{Ab}=$ albite; $\mathrm{K}$-spar = K-feldspar; $\mathrm{Wa}=$ wairakite; $\mathrm{Ep}=$ epidote; $\mathrm{Ca}=$ calcite; $\mathrm{Do}=$ dolomite; $\mathrm{Ma}=$ magnesite; $\mathrm{Ch}=$ chlorite; $\mathrm{Il}=$ illite; $\mathrm{Sm}=$ smectite; $\mathrm{Ms}=$ muscovite; Ser = sericite; $\mathrm{Sn}=$ sphene; $\mathrm{Py}=$ pyrite; $\mathrm{Sp}=$ sphalerite; $\mathrm{Mr}=$ marcasite; $\mathrm{Po}=$ pyrrhotite; $\mathrm{Ta}=$ talc; $\mathrm{Sa}=$ saponite; Ver = vermiculite; $\mathrm{An}=$ anhydrite; $\mathrm{Mag}=$ magnetite; $\mathrm{Ru}=$ rutile. 
Table 6. Summary of downhole mineralogy for Holes 856A and 856B.

\begin{tabular}{|c|c|c|c|c|c|c|c|c|c|c|c|c|c|c|c|c|c|c|c|c|c|c|c|c|c|}
\hline \multirow{2}{*}{$\begin{array}{l}\text { Core, section, } \\
\text { interval (cm) }\end{array}$} & \multirow{2}{*}{$\begin{array}{l}\text { Grain } \\
\text { size }\end{array}$} & \multirow{2}{*}{$\begin{array}{l}\text { Depth } \\
\text { (mbsf) }\end{array}$} & \multicolumn{10}{|c|}{ Detrital } & \multicolumn{13}{|c|}{ Hydrothermal/Authigenic } \\
\hline & & & Qz & Fs & Clay & Micas & $\mathrm{Ch}$ & $\mathrm{Hb}$ & Ep & Mag & $M-f$ & F-py & Qz & Ch-Ms & Mg-sil & Carb & $\mathrm{Ru}$ & $\mathrm{Ba}$ & An & Py & Mr & Po & $\mathrm{Cp}$ & Sp & Hem/op \\
\hline \multicolumn{26}{|l|}{ 139-856A- } \\
\hline $2 \mathrm{H}-1,45-47$ & Silty clay & 3.15 & $x x x$ & $x x x$ & $x x x x x$ & $x x x$ & $\mathrm{xx}$ & $\mathrm{x}$ & & $\mathrm{x}$ & $\mathrm{x}$ & $\mathrm{x}$ & & & & $\mathrm{x}$ & & & & & & & & & \\
\hline $3 \mathrm{H}-5,117-121$ & Silty clay & 19.37 & $x x x$ & $x x x$ & $x x x x x$ & $\mathrm{xxx}$ & $\mathrm{xx}$ & $\mathrm{x}$ & & $\mathrm{x}$ & $\mathrm{x}$ & $\mathrm{x}$ & & & & $\mathrm{x}$ & & & & & & & & & \\
\hline $4 \mathrm{H}-6,55-59$ & Sandy silt & 29.75 & $x \mathrm{xxx}$ & $x x x x$ & $x x x x$ & $x x x$ & $\mathrm{xx}$ & & $\mathrm{xx}$ & $\mathrm{x}$ & $\mathrm{x}$ & & & & & $x x x x$ & & & & $\mathrm{x}$ & & & & & \\
\hline $5 \mathrm{H}-8,71-75$ & Sandy silt + silty clay & 41.29 & $x \mathrm{xxx}$ & $\mathrm{xxxx}$ & $x x x x$ & $x x x$ & $x x$ & & $\mathrm{xx}$ & $\mathrm{x}$ & $\mathrm{x}$ & $\mathrm{x}$ & & & & $x x x$ & & & & $\mathrm{x}$ & $\mathrm{x}$ & & & & \\
\hline $6 \mathrm{H}-3,103-107$ & Silty clay & 44.73 & $x x x x$ & $x x x$ & $x x x x x$ & $x x x$ & $x x x$ & $\mathrm{xx}$ & $x x x$ & $\mathrm{x}$ & & $\mathrm{x}$ & & & & $\mathrm{xx}$ & & & & $\mathrm{x}$ & & & & & \\
\hline $6 \mathrm{H}-4,69-77$ & Sand & 45.89 & $x \mathrm{xxx}$ & $\mathrm{xxx}$ & $\mathrm{xxx}$ & $\mathrm{x}$ & $\mathrm{xx}$ & & $\mathrm{x}$ & $\mathrm{x}$ & & $\mathrm{x}$ & & & & $x x x x x$ & & & & $\mathrm{xx}$ & & & & & \\
\hline $6 \mathrm{H}-6,90-94$ & Sandy silt & 49.10 & $x x x x$ & $x x x x$ & $x x x x$ & $x x x$ & $x x$ & & $x x$ & $x$ & & $x$ & & & & $x x x$ & & & & & & & & & \\
\hline $7 \mathrm{H}-5,70-74$ & Silty clay & 56.90 & $x x x$ & $\mathrm{xxx}$ & $x x x x x$ & $\mathrm{xx}$ & $\mathrm{x}$ & & $\mathrm{x}$ & $\mathrm{x}$ & & $\mathrm{x}$ & & & & & & & & $\mathrm{x}$ & & & & & \\
\hline $8 \mathrm{H}-1,8-10$ & Fine grained silt & 59.78 & $x x x$ & $x x x$ & $x x x x$ & $\mathrm{x}$ & & & $\mathrm{x}$ & & & $\mathrm{x}$ & & & & $x x x x x$ & $\mathrm{x}$ & & & $\mathrm{x}$ & & & & & \\
\hline $8 \mathrm{H}-5,84-87$ & Silty clay & 66.54 & $x x x$ & $\mathrm{xxx}$ & $x x x x x$ & $x x x$ & $\mathrm{x}$ & & $\mathrm{x}$ & $\mathrm{x}$ & & & & & & & & & & $\mathrm{x}$ & & & & & \\
\hline $9 \mathrm{H}-\mathrm{I}, 44-47$ & Silty sand & 69.64 & $x x x x$ & $\mathrm{xxxx}$ & $x x x x$ & $\mathrm{x}$ & $\mathrm{xx}$ & & $x x x$ & $\mathrm{x}$ & & $\mathrm{x}$ & & & & $x x x x$ & & & & $\mathrm{x}$ & & & & & \\
\hline $9 \mathrm{H}-5,41-42$ & Silt & 75.61 & $x x x x$ & $x x x$ & $\mathrm{xxxx}$ & $\hat{x}$ & $\mathrm{x}$ & & $\mathrm{x}$ & $\hat{x}$ & & $\hat{x}$ & & & & $x x x x x$ & & & & $\hat{x}$ & & & & & \\
\hline $11 X-1,70-72$ & Silt + silty clay & 86.90 & $x x x x$ & $x x x$ & $x x x x x$ & $x x$ & $\mathrm{x}$ & & $\mathrm{xx}$ & $\mathrm{x}$ & & $\mathrm{x}$ & & & & $x x x x$ & & & & $\mathrm{x}$ & & & & & \\
\hline $12 \times-2,20-24$ & Silty claystone & 97.40 & $\mathrm{xxx}$ & $\mathrm{xxx}$ & $\mathrm{xxxxx}$ & $\mathrm{xxx}$ & $\mathrm{xx}$ & & $\mathrm{x}$ & & & $\mathrm{x}$ & & & & & & & & $\mathrm{x}$ & & & & & \\
\hline $13 \times-4,47-51$ & Silty clay & 110.27 & $x x x x$ & $\mathrm{xxxx}$ & $\mathrm{xxxxx}$ & $\mathrm{xxx}$ & $\mathrm{xx}$ & & $\mathrm{x}$ & & & $\mathrm{x}$ & & & & & & & & $x$ & & & & & \\
\hline \multicolumn{26}{|l|}{ 139-856B- } \\
\hline $2 \mathrm{H}-5,115-119$ & Silty clay & 8.95 & $x x x$ & $x x x$ & $x x x x x$ & $\mathrm{xxx}$ & $x x x$ & & $\mathrm{x}$ & & & $\mathrm{x}$ & & & & $\mathrm{x}$ & & & & $\mathrm{x}$ & & & & & \\
\hline $3 \mathrm{H}-5,110-113$ & Silt to sand & 18.40 & & & & & & & & & & & & $\mathrm{x}$ & $x x x x$ & & & & & $x x x x x$ & & & & $\mathrm{x}$ & \\
\hline $3 \mathrm{H}-6,34-36$ & Sand and silt & 19.14 & & & & & & & & & & & & & $x x x$ & & & & ${ }^{\mathrm{a}}$ & $x x x x$ & $x x x$ & & $x x x$ & $\mathrm{xx}$ & $x x x x x$ \\
\hline $3 \mathrm{H}-7,28-30$ & Sand to clay & 20.58 & & & & & & & & & & & & & $x x x x$ & & & & & $x x x x$ & $x x x$ & & $\mathrm{x}$ & $\mathrm{xx}$ & $x x x x$ \\
\hline $3 \mathrm{H}-\mathrm{CC}, 28-31$ & Sand to clay & 21.33 & & & & & & & & & & & & $x x x x$ & $\mathrm{xxx}$ ? & & & & & $x x x x$ & $x x x$ & & $\mathrm{xx}$ & $\mathrm{x}$ & $x x x x$ \\
\hline $4 \mathrm{H}-1,145-147$ & Sand to clay & 22.25 & $\mathrm{xxx}$ & $x x x$ & $x x x x x$ & $\mathrm{x}$ & & & & & & & & $\mathrm{xxx}$ & & & & & & $\mathrm{xxx}$ & $x x x x$ & & $x x$ & $\mathrm{x}$ & $x x x x x$ \\
\hline $4 \mathrm{H}-3,35-37$ & Silty clay with sulfides & 24.15 & $\mathrm{xx}$ & $\mathrm{xx}$ & $x \times x \times x$ & $\mathrm{xxx}$ & & & & & & $\mathrm{x}$ & & 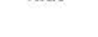 & & & & & & $\mathrm{xxx}$ & $\mathrm{x}$ & & $\mathrm{x}$ & $\mathrm{x}$ & \\
\hline $5 \mathrm{H}-2,67-70$ & Silty clay & 32.47 & $x x x$ & $\mathrm{xxx}$ & $x x x x x$ & $\mathrm{xxx}$ & $\mathrm{x}$ & & & & & & & & & & & & & $\mathrm{xx}$ & & & & & \\
\hline $6 \mathrm{H}-2,23-29$ & Silty clay and silt & 41.53 & $x \times x x$ & $\mathrm{xxx}$ & $\begin{array}{l}x \times x x x \\
x \times x x\end{array}$ & $\mathrm{x}$ & $\hat{x}$ & & & & & & & & & & & & & $\mathrm{x}$ & & & & & \\
\hline $6 \mathrm{H}-4,124-128$ & Silty clay & 45.54 & $\operatorname{xxxx}$ & $x x x$ & $x x x x x$ & $\mathrm{xxx}$ & $\mathrm{x}$ & & & & & $\mathrm{x}$ & & & & & $\mathrm{x}$ & & & $\mathrm{xx}$ & & & & & \\
\hline $7 \mathrm{H}-5,26-32$ & Silty clay & 55.56 & $\mathrm{xxxx}$ & $\mathrm{xxx}$ & $\mathrm{xxxxx}$ & $\mathrm{xxx}$ & $\mathrm{x}$ & & & & & $\mathrm{x}$ & & & & & & & & $\mathrm{x}$ & & & $\mathrm{x}$ & & \\
\hline $8 \mathrm{H}-3,55-57$ & Silty clay & 62.35 & $\mathrm{xxx}$ & $x x$ & $x x x x x$ & $\mathrm{xx}$ & $\mathrm{x}$ & & & & & & & & & & & & & $x x$ & & & & & \\
\hline $10 \mathrm{H}-2,54-58$ & Sandy silt & 72.84 & $x x x x$ & $x x x x x$ & $x x x x$ & $\mathrm{x}$ & $x x$ & & $\mathrm{x}$ & & & $\mathrm{x}$ & & & & & $\mathrm{x}$ & & & $\mathrm{x}$ & & & & & \\
\hline $11 X-5,53-57$ & Silty clay & 79.83 & $x \mathbf{x x x}$ & $x x x x$ & $x x x x x$ & $\mathrm{x}$ & $\mathrm{xx}$ & & & $\mathrm{x}$ & & & & & & & $\mathrm{x}$ & & & $x x$ & & & & & \\
\hline $12 X-4,29-33$ & Silty clay & 86.39 & $x x x x$ & $x x x x$ & $\mathrm{xxxxx}$ & $\mathrm{xx}$ & $\mathrm{xx}$ & & & & & & $\mathrm{x}$ ? & & & & $\mathrm{x}$ & & & $\mathrm{xxx}$ & & & & & \\
\hline $13 \times-2,63-67$ & Siltstone & 93.23 & $\mathrm{xxxx}$ & $x x x x$ & $\mathrm{xxxx}$ & $\mathrm{xxx}$ & $\mathrm{xx}$ & & & & & $\mathrm{x}$ & & & & & $\mathrm{x}$ & & & $\mathrm{xxx}$ & & & & & \\
\hline $14 \mathrm{X}-1,34-36$ & Siltstone & 101.14 & $x x x$ & $\mathrm{xx}$ & $x x x$ & $\mathrm{xxx}$ & $\mathrm{x}$ & & & & & & & $x x x x$ & & & $\mathrm{x}$ & & & $\mathrm{xxx}$ & & & & & \\
\hline $14 X-4,50-53$ & Siltstone & 105.80 & $\mathrm{xxx}$ ? & $\mathrm{xxx}$ & & $\mathrm{xx}$ & $\hat{x}$ & & $\mathrm{x}$ & & & & $\mathrm{xxx}$ & $x x x x x$ & & & $\hat{x}$ & & & $\mathrm{x}$ & & & & & \\
\hline $15 X-1,91-93$ & Silt to silty sand & 111.31 & & & & $\mathrm{x}$ & & & & & & & $x x x x$ & $x x x x x$ & & & $\mathrm{x}$ & & & $\mathrm{x}$ & & $x$ & $\mathrm{x}$ & & \\
\hline $15 X-1,124-126$ & Silt to silty sand & 111.64 & & & & $\mathrm{x}$ & $\mathrm{x}$ & & & & & & $x x x x$ & $\mathrm{xxxx}$ & & & $\mathrm{x}$ & & & $\mathrm{x}$ & & & $\mathrm{x}$ & & \\
\hline $15 \times-2,27-29$ & Silty clay & 112.17 & & & & $\mathrm{xxx}$ & $\mathrm{x}$ & & & & & & $\mathrm{xxx}$ & $\mathrm{xxxxx}$ & & & $\mathrm{x}$ & & & $\mathrm{xx}$ & & & & & \\
\hline $15 \times-2,67-69$ & Siltstone to silty sandstone & 112.57 & & & & & $x x x$ & & & & & & $x x x x$ & $\mathrm{xxxx}$ & & & $\mathrm{x}$ & & & $\mathrm{xx}$ & & & $\mathrm{xx}$ & & \\
\hline $15 \mathrm{X}-3,8-10$ & Silt & 113.48 & & & & $\mathrm{x}$ & $\mathrm{x}$ & & & & & & $x x x x$ & $x x x x$ & & & $\mathrm{x}$ & & & $x$ & & $x$ & $\mathrm{xx}$ & & \\
\hline $15 \times-4,12-14$ & Silty sand & 115.02 & & & & $\mathrm{x}$ & $\mathrm{x}$ & & & & & & $x x x x$ & $x x x x x$ & & & $\mathrm{x}$ & & & $\mathrm{x}$ & & & $\mathrm{x}$ & & \\
\hline $15 X-4,70-72$ & Silty clay & 115.60 & & & & & $\mathrm{x}$ & & & & & & $\mathrm{xxxx}$ & $x x x x x$ & & & $\mathrm{x}$ & & & $\mathrm{x}$ & & & $\mathrm{x}$ & & \\
\hline $15 \times-5,106-108$ & Silt & 117.46 & & & & & $\mathrm{xx}$ & & & & & & $x \times x x$ & $x x x x x$ & & & $\mathrm{xx}$ & & & & & & $\mathrm{xx}$ & & \\
\hline $15 X-6,6-8$ & Sitt & 117.96 & & $\mathrm{xx}$ & & $\mathrm{xx}$ & $\mathrm{xx}$ & & & & & & $x x x x$ & $\mathrm{xxxxx}$ & & & $\mathrm{x}$ & & & $\mathrm{x}$ & & & $\mathrm{x}$ & & \\
\hline $15 X-C C, 20-22$ & Silt or silty claystone & 118.22 & & $\mathrm{x}$ & & & & & & & & & $x x x x$ & $x x x x x$ & & & $\mathrm{x}$ & $\mathrm{x}$ & & $\mathrm{x}$ & & & $\mathrm{x}$ & & \\
\hline
\end{tabular}

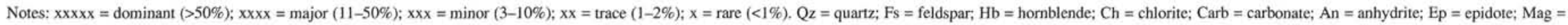
a magnetite; $\mathrm{M}-\mathrm{f}=$ microfossils; $\mathrm{F}-\mathrm{py}=$ framboidal pyrite; $\mathrm{Ba}=$ barite; $\mathrm{Ms}=$ muscovite; $\mathrm{Py}=$ pyrite; $\mathrm{Mr}=$ marcasite; $\mathrm{Po}=$ pyrrhotite; $\mathrm{Cp}=$ chalcopyrite; $\mathrm{Sp}=$ sphalerite; Hem/op = hematite $\pm \mathrm{Fe}$-oxides.

$\mathrm{a}=$ anhydrite detected by SEM only. 
Table 7. Electron microprobe data for chlorite in unaltered and hydrothermally altered hemipelagic and turbiditc sediment, Leg 139.

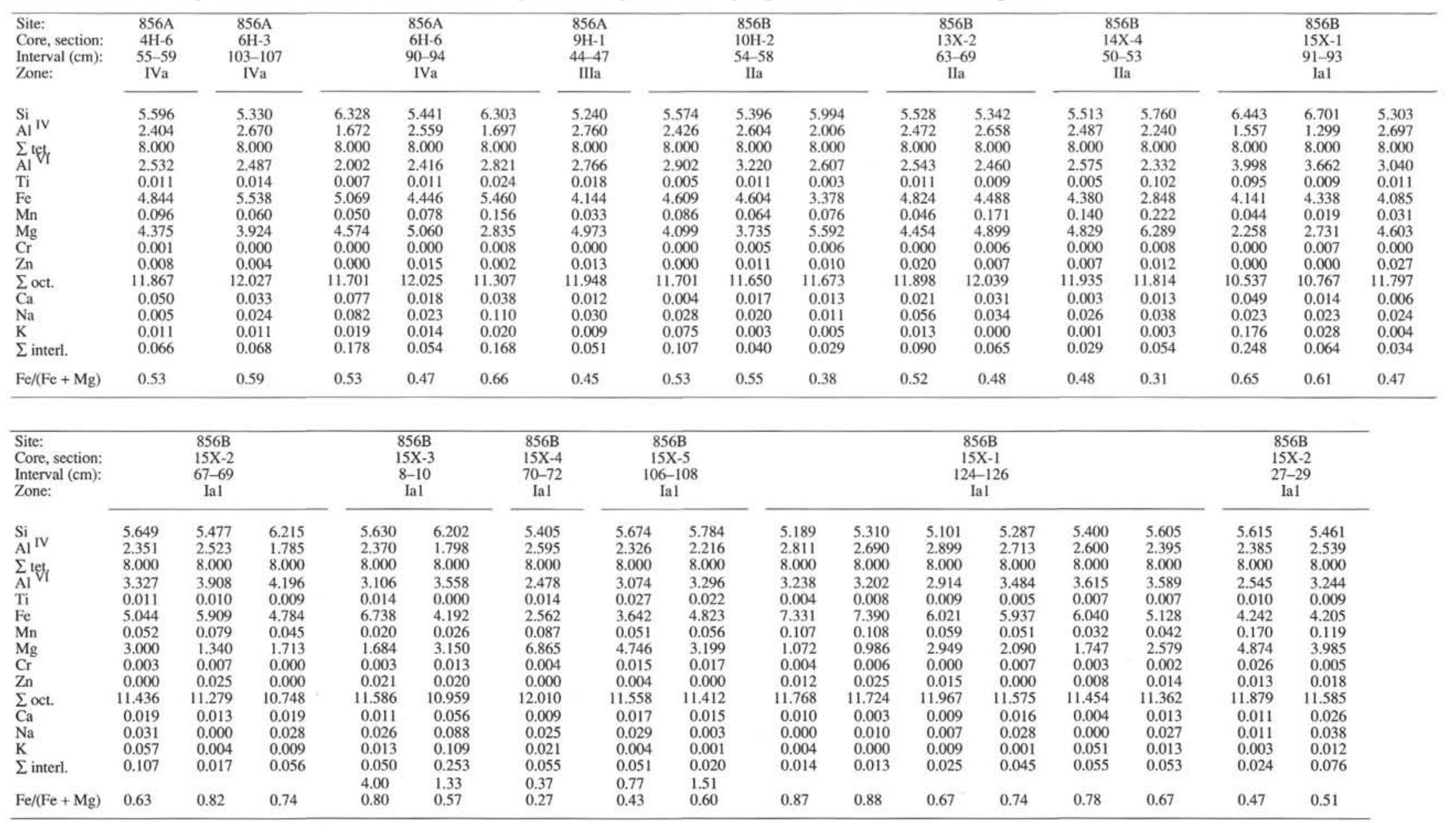


Table 7 (continued).

\begin{tabular}{|c|c|c|c|c|c|c|c|c|c|c|c|c|c|c|c|}
\hline $\begin{array}{l}\text { Site: } \\
\text { Core, section: } \\
\text { Interval (cm): } \\
\text { Zone: }\end{array}$ & \multicolumn{4}{|c|}{$\begin{array}{c}856 \mathrm{~B} \\
15 \mathrm{X}-\mathrm{CC} \\
20-22 \\
\text { Ia2 }\end{array}$} & \multicolumn{2}{|c|}{$\begin{array}{c}856 \mathrm{H} \\
3 \mathrm{R}-3 \\
72-74 \\
\mathrm{MS}\end{array}$} & \multicolumn{2}{|c|}{$\begin{array}{c}856 \mathrm{H} \\
4 \mathrm{R}-1 \\
88-90 \\
\text { MS }\end{array}$} & \multicolumn{3}{|c|}{$\begin{array}{c}856 \mathrm{H} \\
4 \mathrm{R}-2 \\
43-45 \\
\text { MS }\end{array}$} & \multicolumn{2}{|c|}{$\begin{array}{c}857 \mathrm{C} \\
21 \mathrm{R}-1 \\
24-26 \\
\mathrm{IV} \mathrm{c}\end{array}$} & \multirow{2}{*}{$\begin{array}{c}\begin{array}{c}857 \mathrm{C} \\
28 \mathrm{R}-\mathrm{CC} \\
\mathrm{IIc}\end{array} \\
6.422\end{array}$} & \multirow{2}{*}{$\begin{array}{c}857 \mathrm{C} \\
30 \mathrm{R}-1 \\
116-120 \\
\mathrm{IIIC}\end{array}$} \\
\hline $\mathrm{Si}$ & 6.115 & 6.189 & 6.074 & 6.281 & 6.457 & 6.489 & 6.422 & 6.461 & 6.092 & 6.379 & 6.204 & 6.767 & 6.510 & & \\
\hline $\mathrm{Al}^{\mathrm{IV}}$ & 1.885 & 1.811 & 1.926 & 1.719 & 1.543 & 1.511 & 1.578 & 1.539 & 1.908 & 1.621 & 1.796 & 1.233 & 1.490 & 1.578 & 1.670 \\
\hline$\sum$ tef & 8.000 & 8.000 & 8.000 & 8.000 & 8.000 & 8.000 & 8.000 & 8.000 & 8.000 & 8.000 & 8.000 & 8.000 & 8.000 & 8.000 & 8.000 \\
\hline $\mathrm{Al}=\mathrm{VI}$ & 2.339 & 2.356 & 2.469 & 2.473 & 2.229 & 2.224 & 2.728 & 2.817 & 2.262 & 1.912 & 2.165 & 2.497 & 1.886 & 2.050 & 2.517 \\
\hline $\mathrm{Ti}$ & 0.011 & 0.005 & 0.012 & 0.011 & 0.009 & 0.013 & 0.008 & 0.005 & 0.007 & 0.008 & 0.008 & 0.004 & 0.031 & 0.232 & 0.033 \\
\hline $\mathrm{Fe}$ & 5.213 & 5.274 & 5.298 & 4.088 & 4.219 & 3.738 & 4.017 & 4.040 & 4.141 & 3.492 & 3.908 & 4.369 & 3.865 & 4.259 & 4.058 \\
\hline Mn & 0.035 & 0.029 & 0.034 & 0.030 & 0.027 & 0.022 & 0.043 & 0.050 & 0.034 & 0.032 & 0.029 & 0.046 & 0.043 & 0.089 & 0.050 \\
\hline $\mathrm{Mg}$ & 4.125 & 3.995 & 3.863 & 4.938 & 5.051 & 5.564 & 4.601 & 4.359 & 5.323 & 6.322 & 5.653 & 4.208 & 5.786 & 4.659 & 4.679 \\
\hline $\mathrm{Cr}$ & 0.002 & 0.000 & 0.000 & 0.008 & 0.005 & 0.009 & 0.000 & 0.006 & 0.002 & 0.004 & 0.000 & 0.005 & 0.005 & 0.010 & 0.005 \\
\hline $\mathrm{Zn}$ & 0.000 & 0.023 & 0.011 & 0.000 & 0.032 & 0.012 & 0.000 & 0.052 & 0.005 & 0.027 & 0.009 & 0.017 & 0.000 & 0.016 & 0.027 \\
\hline$\sum$ oct. & 11.724 & 11.682 & 11.686 & 11.549 & 11.571 & 11.581 & 11.398 & 11.328 & 11.776 & 11.796 & 11.772 & 11.145 & 11.615 & 11.315 & 11.370 \\
\hline $\mathrm{Ca}$ & 0.019 & 0.021 & 0.021 & 0.036 & 0.029 & 0.022 & 0.017 & 0.015 & 0.018 & 0.022 & 0.011 & 0.161 & 0.105 & 0.125 & 0.082 \\
\hline $\mathrm{Na}$ & 0.033 & 0.039 & 0.011 & 0.034 & 0.083 & 0.044 & 0.000 & 0.011 & 0.042 & 0.047 & 0.048 & 0.104 & 0.051 & 0.054 & 0.129 \\
\hline K & 0.004 & 0.001 & 0.007 & 0.009 & 0.009 & 0.002 & 0.003 & 0.009 & 0.001 & 0.006 & 0.000 & 0.007 & 0.046 & 0.121 & 0.049 \\
\hline$\Sigma$ interl. & 0.056 & 0.060 & 0.039 & 0.080 & 0.121 & 0.068 & 0.020 & 0.035 & 0.061 & 0.075 & 0.059 & 0.272 & 0.202 & 0.300 & 0.259 \\
\hline & 1.26 & 1.32 & 1.37 & 0.83 & 0.84 & 0.67 & 0.87 & 0.93 & 0.78 & 0.55 & 0.69 & 1.04 & 0.67 & 0.91 & 0.87 \\
\hline $\mathrm{Fe} /(\mathrm{Fe}+\mathrm{Mg})$ & 0.56 & 0.57 & 0.58 & 0.45 & 0.46 & 0.40 & 0.47 & 0.48 & 0.44 & 0.36 & 0.41 & 0.51 & 0.40 & 0.48 & 0.46 \\
\hline
\end{tabular}

\begin{tabular}{|c|c|c|c|c|c|c|c|c|c|c|c|c|c|c|c|c|c|c|}
\hline $\begin{array}{l}\text { Site: } \\
\text { Core, section: } \\
\text { Interval }(\mathrm{cm}) \text { : } \\
\text { Zone: }\end{array}$ & \multicolumn{2}{|c|}{$\begin{array}{c}857 \mathrm{C} \\
61 \mathrm{R}-1 \\
129-131 \\
\text { Ic }\end{array}$} & $\begin{array}{c}858 \mathrm{~A} \\
21 \mathrm{X}-3 \\
57-59 \\
\mathrm{IVb}\end{array}$ & $\begin{array}{c}858 \mathrm{~A} \\
25 \mathrm{X}-1 \\
29-32 \\
\mathrm{IIb} \\
\end{array}$ & \multicolumn{2}{|c|}{$\begin{array}{c}858 \mathrm{C} \\
5 \mathrm{H}-\mathrm{CC} \\
7-10 \\
\mathrm{IVb}\end{array}$} & $\begin{array}{c}858 \mathrm{D} \\
2 \mathrm{H}-3 \\
34-36 \\
\mathrm{Vb} \\
\end{array}$ & \multicolumn{2}{|c|}{$\begin{array}{c}858 \mathrm{D} \\
2 \mathrm{H}-\mathrm{CC} \\
10-12 \\
\mathrm{Vb}\end{array}$} & \multicolumn{3}{|c|}{$\begin{array}{c}858 \mathrm{~F} \\
4 \mathrm{R}-\mathrm{CC} \\
8-10 \\
\mathrm{Ib}\end{array}$} & \multicolumn{3}{|c|}{$\begin{array}{c}858 \mathrm{~F} \\
9 \mathrm{R}-\mathrm{CC} \\
9-11 \\
\mathrm{Ib}\end{array}$} & \multicolumn{3}{|c|}{$\begin{array}{c}858 \mathrm{~F} \\
14 \mathrm{R}-1 \\
10-12 \\
\mathrm{IIb}\end{array}$} \\
\hline $\mathrm{Si}$ & 6.285 & 6.394 & 6.106 & 6.190 & 5.772 & 5.680 & 5.115 & 5.147 & 5.549 & 5.524 & 5.599 & 5.397 & 5.586 & 5.651 & 5.354 & 5.272 & 5.497 & 6.331 \\
\hline $\mathrm{Al}^{\mathrm{IV}}$ & 1.715 & 1.606 & 1.894 & 1.810 & 2.228 & 2.320 & 2.885 & 2.853 & 2.451 & 2.476 & 2.401 & 2.603 & 2.414 & 2.349 & 2.646 & 2.728 & 2.503 & 1.669 \\
\hline$\sum$ tet & 8.000 & 8.000 & 8.000 & 8.000 & 8.000 & 8.000 & 8.000 & 8.000 & 8.000 & 8.000 & 8.000 & 8.000 & 8.000 & 8.000 & 8.000 & 8.000 & 8.000 & 8.000 \\
\hline $\mathrm{Al}$ II & 2.349 & 2.333 & 2.497 & 3.614 & 2.868 & 2.777 & 0.886 & 3.122 & 2.522 & 2.695 & 2.623 & 2.894 & 2.512 & 2.428 & 2.654 & 2.889 & 2.959 & 2.101 \\
\hline $\mathrm{Ti}$ & 0.004 & 0.006 & 0.032 & 0.018 & 0.016 & 0.007 & $\begin{array}{l}0.000 \\
1.092\end{array}$ & 0.017 & 0.004 & 0.012 & 0.006 & 0.007 & 0.021 & 0.003 & 0.008 & 0.009 & 0.010 & 0.285 \\
\hline $\mathrm{Fe}$ & 2.521 & 2.754 & 3.118 & 3.685 & 4.627 & 5.171 & 4.757 & 5.349 & 4.427 & 4.890 & 4.483 & 5.545 & 4.431 & 4.386 & 4.424 & 4.131 & 5.966 & 3.376 \\
\hline Mn & 0.096 & 0.080 & 0.043 & 0.065 & 0.061 & 0.130 & 0.077 & 0.078 & 0.070 & 0.084 & 0.040 & 0.061 & 0.160 & 0.076 & 0.091 & 0.118 & 0.063 & 0.089 \\
\hline $\mathrm{Mg}$ & 6.426 & 6.264 & 5.874 & 2.856 & 4.051 & 3.631 & 4.985 & 3.229 & 4.889 & 4.138 & 4.650 & 3.234 & 4.751 & 5.008 & 4.733 & 4.728 & 2.680 & 5.472 \\
\hline $\mathrm{Cr}$ & 0.004 & 0.022 & 0.020 & 0.000 & 0.000 & 0.006 & 0.009 & 0.013 & 0.005 & 0.000 & 0.007 & 0.005 & 0.001 & 0.006 & 0.008 & 0.002 & 0.018 & 0.012 \\
\hline $\mathrm{Zn}$ & 0.010 & 0.044 & 0.032 & 0.022 & 0.019 & 0.009 & 0.013 & 0.009 & 0.010 & 0.034 & 0.043 & 0.054 & 0.019 & 0.016 & 0.027 & 0.023 & 0.035 & 0.066 \\
\hline$\sum$ oct. & 11.410 & 11.504 & 11.615 & 10.260 & 11.642 & 11.731 & 11.820 & 11.816 & 11.926 & 11.852 & 11.853 & 11.800 & 11.896 & 11.923 & 11.944 & 11.900 & 11.730 & 11.401 \\
\hline $\mathrm{Ca}$ & 0.251 & 0.082 & 0.012 & 0.045 & 0.018 & 0.017 & 0.056 & 0.010 & 0.007 & 0.015 & 0.024 & 0.028 & 0.023 & 0.017 & 0.024 & 0.001 & 0.013 & 0.057 \\
\hline $\mathrm{Na}$ & 0.030 & 0.061 & 0.050 & 1.441 & 0.004 & 0.019 & 0.040 & 0.027 & 0.042 & 0.019 & 0.005 & 0.028 & 0.019 & 0.027 & 0.033 & 0.015 & 0.012 & 0.058 \\
\hline $\mathrm{K}$ & 0.000 & 0.006 & 0.008 & 0.109 & 0.004 & 0.008 & 0.015 & 0.007 & 0.009 & 0.005 & 0.000 & 0.005 & 0.000 & 0.002 & 0.000 & 0.001 & 0.009 & 0.012 \\
\hline$\tilde{\Sigma}$ interl. & 0.281 & 0.150 & 0.070 & 1.594 & 0.026 & 0.044 & 0.111 & 0.043 & 0.058 & 0.039 & 0.028 & 0.061 & 0.043 & 0.046 & 0.058 & 0.017 & 0.033 & 0.126 \\
\hline & 0.39 & 0.44 & 0.53 & 1.29 & 1.14 & 1.42 & 0.95 & 1.66 & 0.91 & 1.18 & 0.96 & 1.71 & 0.93 & 0.88 & 0.93 & 0.87 & 2.23 & 0.62 \\
\hline $\mathrm{Fe} /(\mathrm{Fe}+\mathrm{Mg})$ & 0.28 & 0.31 & 0.35 & 0.56 & 0.53 & 0.59 & 0.49 & 0.62 & 0.48 & 0.54 & 0.49 & 0.63 & 0.48 & 0.47 & 0.48 & 0.47 & 0.69 & 0.38 \\
\hline
\end{tabular}

Notes: Calculated on the basis of $28(\mathrm{O}), 16(\mathrm{OH}) ; \mathrm{Fe}^{2} \mathrm{Fe}^{2+} . \mathrm{MS}=$ massive sulfide. 


\section{Site 856}

A

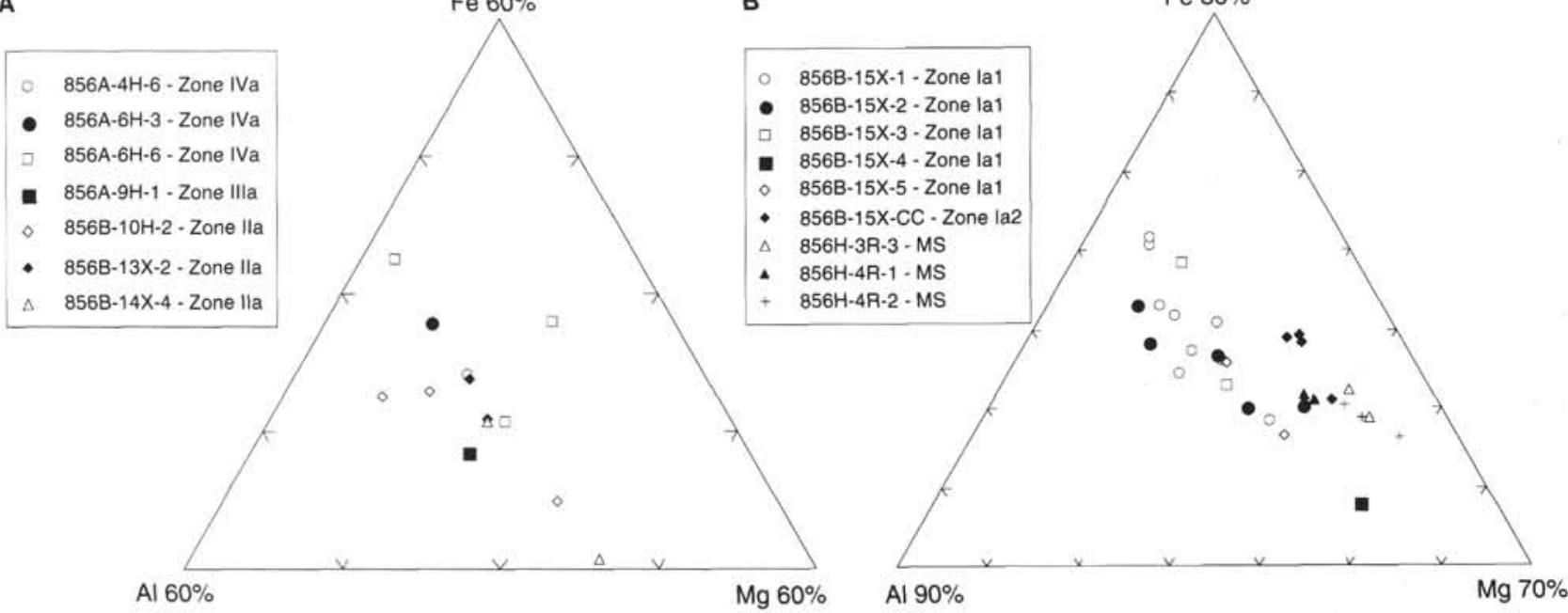

C

D

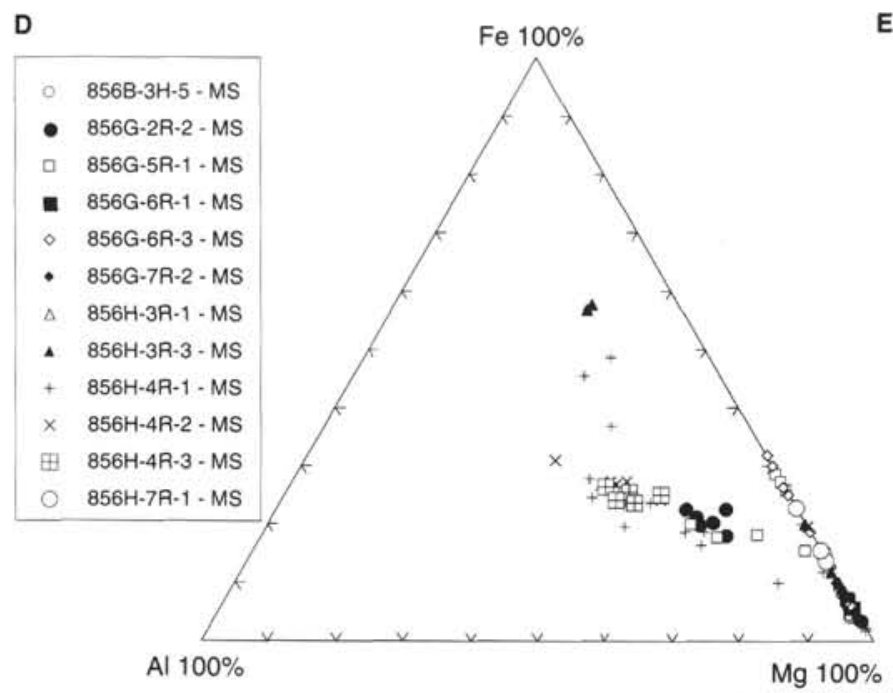

E

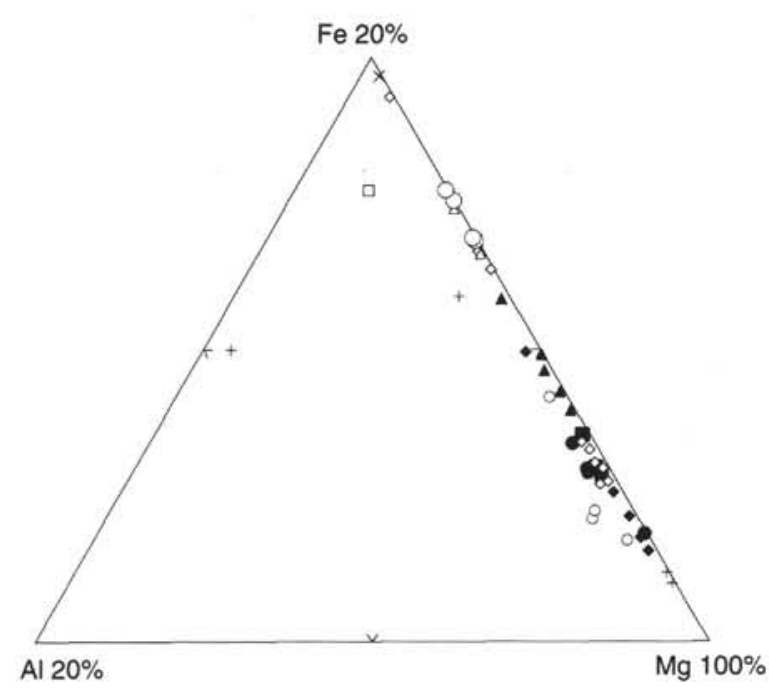

Figure 15. Ternary $\mathrm{Al}_{2} \mathrm{O}_{3}-\mathrm{Fe}_{2} \mathrm{O}_{3}-\mathrm{MgO}$ diagram of clay and chlorite minerals by site. A. Chlorite from Site 856 , alteration Zone IVa through IIa. B. Chlorite from Site 856, alteration Zone Ia and massive sulfides. C. Clay minerals from Site 856. D. Talc and saponite minerals from Site 856. E. Enlargement of field for talc minerals from Site 856. F. Chlorite from Site 858. G. Clay minerals from Site 858. H. Chlorite minerals from Site 857. I. Clay minerals from Site 857. Data from Tables 7 through 9. 


\section{Site 858}

G

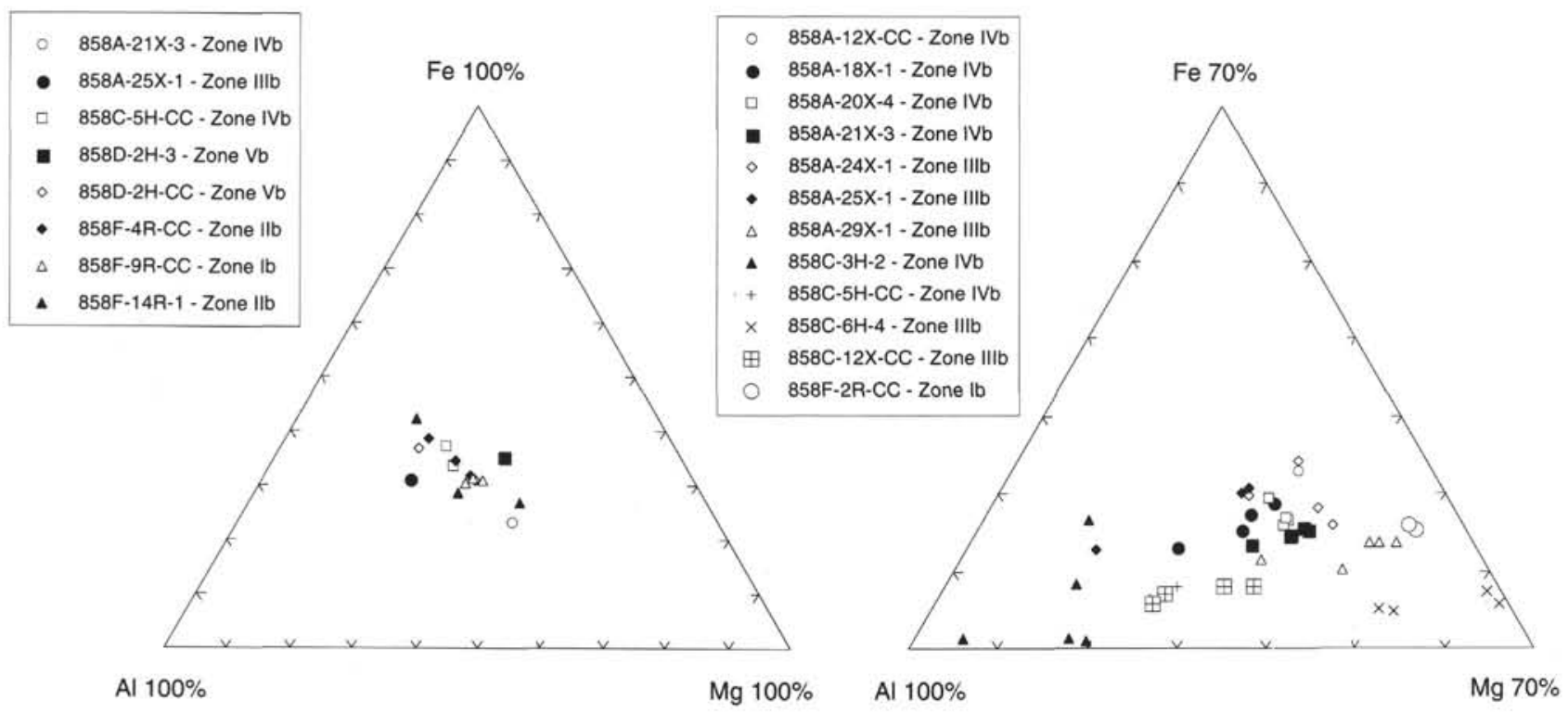

\section{Site 857}

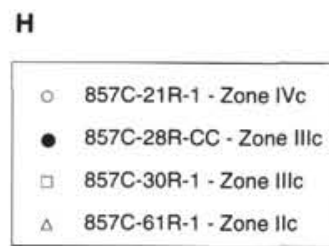

\section{Fe $100 \%$}

I

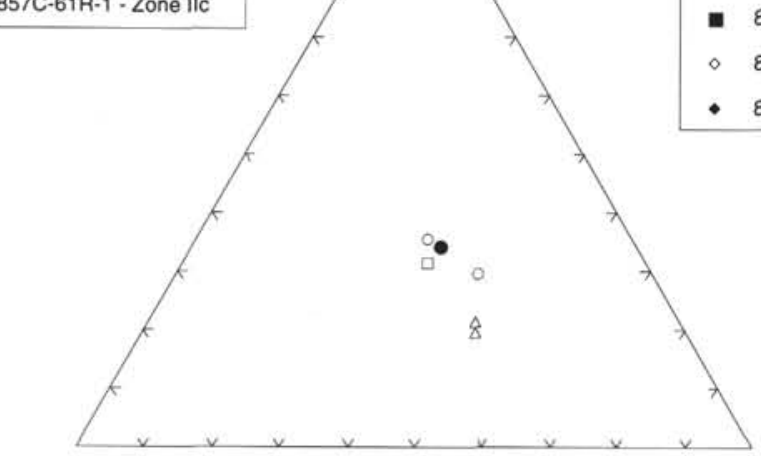

Al $100 \%$

$\operatorname{Mg} 100 \%$

Al $100 \%$

$\mathrm{Fe} 70 \%$

Figure 15 (continued).

with depth below 150 mbsf, reaching a maximum of An 15 in Sample 139-858F-18R-1, 14-16 cm. Pyrite occurs as disseminated euhedral to anhedral crystals and more rarely in veins.

\section{Hydrothermal Minerals Associated with Massive Sulfides}

The only massive sulfides recovered at AAV during Leg 139 occur between 10.7 to $11.5 \mathrm{mbsf}$ in Hole 858B (Fig. 6; Goodfellow and Peter, this volume). The massive sulfide is composed of pyrite, sphalerite, chalcopyrite, isocubanite, pyrrhotite, and marcasite. Pyritic hemipelagic and turbiditic sediments are cut by anhydrite veins between 11.5 and 24 mbsf. The gangue silicate interstitial to massive sulfide is compositionally similar to talc (Table 9) that has been documented for massive sulfides recovered in shallow cores from AAV (Goodfellow et al., in press; Goodfellow and Franklin, in press). Fine-grained anhedral to subhedral dolomite (up to $45 \%$; Table 11; Fig. 17B) with abundant fluid inclusions also occurs interstitially to massive sulfide.

Saponite clays are dominant to a depth of $2 \mathrm{mbsf}$ in Hole $858 \mathrm{~B}$ and have been described in detail from piston cores (Goodfellow et al., in press). Clasts (up to $500 \mu \mathrm{m}$ ) of hydrothermal clays (Sample 139$856 \mathrm{~B}-1 \mathrm{H}-2,50-54 \mathrm{~cm}$ ) are composed primarily of saponite and are similar to saponite observed in hydrothermal sediment near active vents (Goodfellow and Franklin, in press).

\section{Site 857}

Four alteration zones have been identified at Site 857; these are summarized in Table 5. The textural and mineralogical characteristics are presented below. 


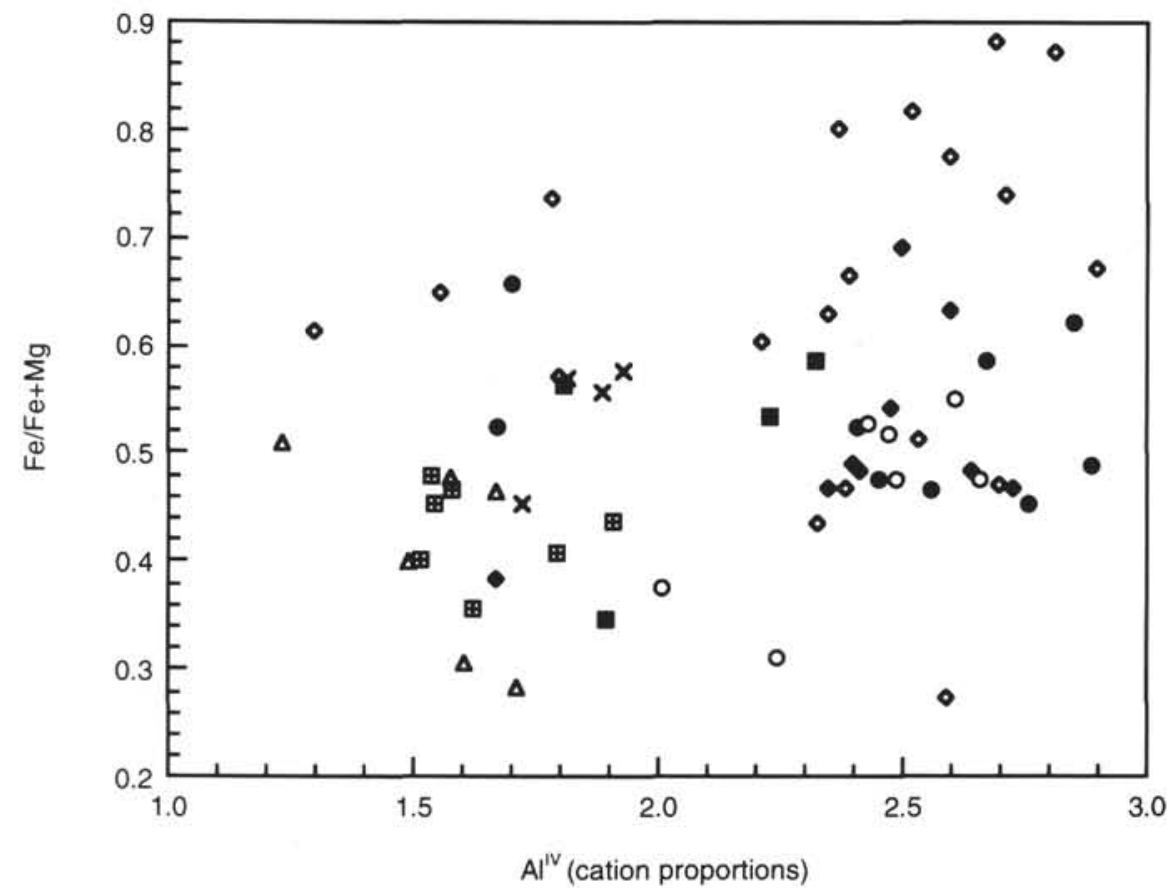

\begin{tabular}{|llll|}
\hline$\bullet$ & 856 Zone IIla & $\Delta$ & 857 Zone IIlc \\
○ & 856 Zone Ila & $\bullet$ & 858 Zone Vb \\
$\bullet$ & 856 Zone la1 & - & 858 Zone IVb/lllb \\
× & 856 Zone la2 & $\bullet$ & 858 Zone IIb/lb \\
田 & 856 massive sulfide & & \\
\hline
\end{tabular}

Figure 16. $\mathrm{Al}^{\mathrm{IV}}$ vs. $\mathrm{Fe} /(\mathrm{Fe}+\mathrm{Mg})$ for chlorite minerals from all sites. $\mathrm{Al}^{\mathrm{IV}}$ calculated by stoichiometry. Data from Table 7.

\section{Zone IVc}

This zone consists of calcite-clay-pyrite and occurs between 70 and 300 mbsf in Holes 857A (Fig. 9) and 857C (Fig. 10). Detrital hornblende was not observed in Hole 857A below 26 mbsf (Table 14), although hornblende was detected by XRD to a depth of $105 \mathrm{mbsf}$ in Hole $857 \mathrm{~A}$ and to a depth of $82 \mathrm{mbsf}$ in Hole $857 \mathrm{C}$ (Davis, Mottl, Fisher, et al., 1992). Epidote is a common accessory mineral in Holes 857A, 857C, and 857D (Table 14). The epidote in Hole 857A and above $450 \mathrm{mbsf}$ in Hole $857 \mathrm{C}$ is interpreted to be of detrital origin, whereas epidote below 450 mbsf in Hole 857C and in Hole 857D is of hydrothermal origin. Detrital epidote is a trace component (typically $<2 \mathrm{vol} \%$ ) in unaltered sediment and consists of anhedral to ragged grains that are concentrated in turbiditic sediment. Detrital epidote is also more Fe-rich and $\mathrm{Al}$-poor compared to authigenic epidote (Table 4; Fig. 13).

Disseminated euhedral to anhedral pyrite occurs throughout the entire sedimentary sequence at Site 857 and pyrite commonly infills burrows to a depth of $350 \mathrm{mbsf}$ (Pl. 4, Fig. 4). Framboidal pyrite persists to the bottom of Hole $857 \mathrm{C}$. Magnetite is an accessory phase in Holes $857 \mathrm{~A}$ and $857 \mathrm{C}$ but is altered to pyrite below $241 \mathrm{mbsf}$.

Clay minerals are partially recrystallized between $15 \mathrm{mbsf}$ and $268 \mathrm{mbsf}$ in Holes 857A and 857C. At depths $>268 \mathrm{mbsf}$, the clays are completely recrystallized and display common extinction and parallel alignment. The clays from Holes $857 \mathrm{~A}$ and $857 \mathrm{C}$ are probably smectite or illite ( $\mathrm{Si}, \mathrm{Al}, \mathrm{Mg}, \mathrm{Fe}, \mathrm{Na}, \mathrm{K}, \mathrm{Ca}$ and minor Ti; Table 8 ; Fig. $15 \mathrm{H}, \mathrm{I}$ ). The high Na contents of some clays (Table 8) suggests a Na-montmorillonite.

Carbonate cement and concretions are a minor to major component of the sediments between 53 and $450 \mathrm{mbsf}$ (Table 14). Carbonate is less common below 300 mbsf. Carbonate concretions may be graded (e.g., Sample 139-857C-9R-1, 8-9 cm) or laminated, and in one sample laminae are offset several $\mathrm{mm}$ by microfaults (Sample 139-857C-6R1, 1-2 cm; Pl. 4, Fig. 5). Calcite is the dominant carbonate mineral, with the exception of a narrow zone near the top of Hole $857 \mathrm{C}$ where dolomite occurs (85-105 mbsf) (Table 11; Fig. 17C). Carbonate is visually absent in Hole 857D, consistent with low CO2 (Goodfellow and Peter, this volume), although dolomite was detected by XRD in Sample 139-857D-5R-1, 26-28 cm.

\section{Zone IIIc}

Zone IIIc consists of albite-chlorite-pyrite and occurs between 250 and 450 mbsf in Hole $857 \mathrm{C}$ (Fig. 10). Detrital quartz contains abundant fluid inclusions below $330 \mathrm{mbsf}$ and increasingly diffuse boundaries below $395 \mathrm{mbsf}$ in Hole 857C and Hole 857D. Quartzepidote-carbonate veins and vugs occur at $399 \mathrm{mbsf}$ in Hole 857C. At depths greater than $300 \mathrm{mbsf}$, detrital plagioclase has been altered to albite (Table 3, Fig. 12C; Pl. 4, Fig. 6) and the anorthite content of plagioclase decreases from An 58 at 48 mbsf to less than An 9 below 314 mbsf (Table 3; Fig. 12C). K-feldspar is partially altered to sericite/ chlorite below 47 mbsf. Shipboard logging noted clasts of massive sulfide at 388 mbsf (Davis, Mottl, Fisher, et al., 1992).

\section{Zone IIc}

This zone consists of quartz-chlorite-epidote-pyrite \pm sphene below 450 mbsf in Holes 857C and 857D (Figs. 10 and 11). Detrital quartz displays ragged and diffuse grain boundaries, with abundant fluid inclusions. Detrital K-feldspar is altered to chlorite and detrital 
Table 8. Electron microprobe data for clay minerals in unaltered and hydrothermally altered hemipelagic and turbiditic sediment, Leg 139.

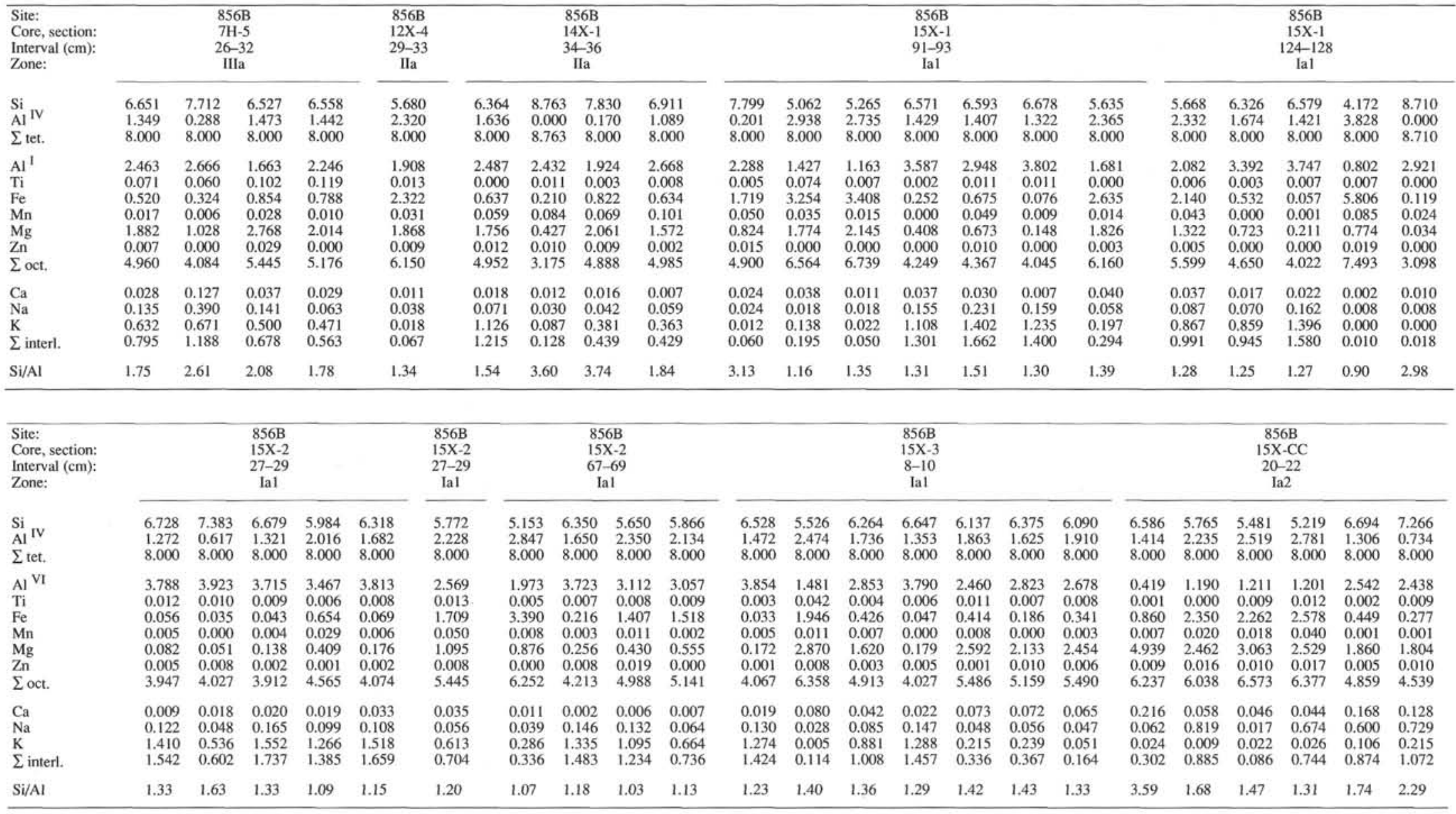


Table 8 (continued).

\begin{tabular}{|c|c|c|c|c|c|c|c|c|c|c|c|c|c|c|c|c|c|c|}
\hline $\begin{array}{l}\text { Site: } \\
\text { Core, section: } \\
\text { Interval }(\mathrm{cm}) \text { : } \\
\text { Zone: }\end{array}$ & & $\begin{array}{l}857 \mathrm{C} \\
9 \mathrm{R}-1 \\
8-9 \\
\mathrm{IVC}\end{array}$ & & $\begin{array}{c}857 \mathrm{C} \\
13 \mathrm{R}-1 \\
6-8 \\
\mathrm{IV} c\end{array}$ & & & & & & & & & $\begin{array}{l}C \\
-2 \\
53 \\
c\end{array}$ & & & $\begin{array}{c}857 \mathrm{C} \\
44 \mathrm{R}-1 \\
137-140 \\
\text { Ilc }\end{array}$ & & $\begin{array}{c}858 \mathrm{~A} \\
12 \mathrm{X}-\mathrm{CC} \\
11-12 \\
\mathrm{IVb}\end{array}$ \\
\hline $\begin{array}{l}S i \\
\mathrm{Al}^{\mathrm{A}}{ }^{\mathrm{IV}} \\
\Sigma\end{array}$ & $\begin{array}{l}6.791 \\
1.209 \\
8.000\end{array}$ & $\begin{array}{l}7.003 \\
0.997 \\
8.000\end{array}$ & $\begin{array}{l}7.105 \\
0.895 \\
8.000\end{array}$ & $\begin{array}{l}6.785 \\
1.215 \\
8.000\end{array}$ & $\begin{array}{l}8.102 \\
0.000 \\
8.102\end{array}$ & $\begin{array}{l}6.331 \\
1.669 \\
8.000\end{array}$ & $\begin{array}{l}6.808 \\
1.192 \\
8.000\end{array}$ & $\begin{array}{l}6.522 \\
1.478 \\
8.000\end{array}$ & $\begin{array}{l}7.221 \\
0.779 \\
8.000\end{array}$ & $\begin{array}{l}7.298 \\
0.702 \\
8.000\end{array}$ & $\begin{array}{l}6.721 \\
1.279 \\
8.000\end{array}$ & $\begin{array}{l}7.331 \\
0.669 \\
8.000\end{array}$ & $\begin{array}{l}7.294 \\
0.706 \\
8.000\end{array}$ & $\begin{array}{l}6.204 \\
1.796 \\
8.000\end{array}$ & $\begin{array}{l}7.334 \\
0.666 \\
8.000\end{array}$ & $\begin{array}{l}6.684 \\
1.316 \\
8.000\end{array}$ & $\begin{array}{l}6.314 \\
1.686 \\
8.000\end{array}$ & $\begin{array}{l}6.162 \\
1.838 \\
8.000\end{array}$ \\
\hline $\begin{array}{l}\mathrm{Al}^{1} \\
\mathrm{Ti}^{2} \\
\mathrm{Fe} \\
\mathrm{Mn} \\
\mathrm{Mg} \\
\mathrm{Zn} \\
\sum \text { oct. }\end{array}$ & $\begin{array}{l}1.882 \\
0.055 \\
1.034 \\
0.013 \\
1.275 \\
0.019 \\
4.278\end{array}$ & $\begin{array}{l}1.736 \\
0.090 \\
0.791 \\
0.031 \\
1.032 \\
0.000 \\
3.680\end{array}$ & $\begin{array}{l}2.264 \\
0.046 \\
0.609 \\
0.015 \\
0.839 \\
0.019 \\
3.790\end{array}$ & $\begin{array}{l}1.243 \\
0.085 \\
1.471 \\
0.020 \\
2.273 \\
0.001 \\
5.093\end{array}$ & $\begin{array}{l}2.883 \\
0.051 \\
0.378 \\
0.018 \\
0.515 \\
0.018 \\
3.863\end{array}$ & $\begin{array}{l}1.991 \\
0.033 \\
1.269 \\
0.029 \\
1.780 \\
0.000 \\
5.102\end{array}$ & $\begin{array}{l}2.127 \\
0.051 \\
1.137 \\
0.019 \\
1.385 \\
0.000 \\
4.720\end{array}$ & $\begin{array}{l}2.200 \\
0.067 \\
0.961 \\
0.030 \\
1.199 \\
0.000 \\
4.457\end{array}$ & $\begin{array}{l}2.358 \\
0.127 \\
0.673 \\
0.035 \\
0.730 \\
0.019 \\
3.941\end{array}$ & $\begin{array}{l}2.434 \\
0.039 \\
0.911 \\
0.008 \\
0.901 \\
0.017 \\
4.310\end{array}$ & $\begin{array}{l}1.632 \\
0.275 \\
1.325 \\
0.009 \\
1.404 \\
0.005 \\
4.651\end{array}$ & $\begin{array}{l}1.963 \\
0.150 \\
1.166 \\
0.019 \\
0.869 \\
0.000 \\
4.168\end{array}$ & $\begin{array}{l}2.575 \\
0.027 \\
0.732 \\
0.023 \\
0.732 \\
0.000 \\
4.089\end{array}$ & $\begin{array}{l}1.331 \\
0.113 \\
1.532 \\
0.040 \\
1.643 \\
0.001 \\
4.661\end{array}$ & $\begin{array}{l}2.13 \\
0.048 \\
1.070 \\
0.011 \\
1.256 \\
0.000 \\
4.519\end{array}$ & $\begin{array}{l}2.470 \\
0.028 \\
1.035 \\
0.011 \\
1.275 \\
0.000 \\
4.818\end{array}$ & $\begin{array}{l}2.273 \\
0.067 \\
0.985 \\
0.022 \\
1.141 \\
0.027 \\
4.515\end{array}$ & $\begin{array}{l}1.515 \\
0.054 \\
1.719 \\
0.011 \\
2.394 \\
0.010 \\
5.703\end{array}$ \\
\hline $\begin{array}{l}\mathrm{Ca} \\
\mathrm{Na} \\
\mathrm{K} \\
\Sigma \text { interl. }\end{array}$ & $\begin{array}{l}0.944 \\
0.422 \\
0.345 \\
1.711\end{array}$ & $\begin{array}{l}1.311 \\
0.625 \\
0.459 \\
2.395\end{array}$ & $\begin{array}{l}1.045 \\
0.585 \\
0.285 \\
1.915\end{array}$ & $\begin{array}{l}0.196 \\
0.973 \\
0.238 \\
1.407\end{array}$ & $\begin{array}{l}0.173 \\
0.451 \\
0.082 \\
0.707\end{array}$ & $\begin{array}{l}0.137 \\
0.791 \\
0.344 \\
1.271\end{array}$ & $\begin{array}{l}0.244 \\
0.697 \\
0.337 \\
1.278\end{array}$ & $\begin{array}{l}0.173 \\
1.634 \\
0.249 \\
2.056\end{array}$ & $\begin{array}{l}0.236 \\
1.269 \\
0.544 \\
2.049\end{array}$ & $\begin{array}{l}0.121 \\
1.027 \\
0.301 \\
1.449\end{array}$ & $\begin{array}{l}0.425 \\
0.540 \\
0.386 \\
1.351\end{array}$ & $\begin{array}{l}0.240 \\
1.068 \\
0.484 \\
1.792\end{array}$ & $\begin{array}{l}0.087 \\
1.464 \\
0.237 \\
1.789\end{array}$ & $\begin{array}{l}1.028 \\
0.441 \\
0.420 \\
1.889\end{array}$ & $\begin{array}{l}0.106 \\
0.983 \\
0.194 \\
1.284\end{array}$ & $\begin{array}{l}0.052 \\
0.117 \\
0.921 \\
1.090\end{array}$ & $\begin{array}{l}0.105 \\
1.572 \\
0.452 \\
2.129\end{array}$ & $\begin{array}{l}0.109 \\
0.157 \\
0.423 \\
0.688\end{array}$ \\
\hline $\mathrm{Si} / \mathrm{Al}$ & 2.20 & 2.56 & 2.25 & 2.76 & 2.81 & 1.73 & 2.05 & 1.77 & 2.30 & 2.33 & 2.31 & 2.78 & 2.22 & 1.98 & 2.62 & 1.77 & 1.59 & 1.84 \\
\hline
\end{tabular}

\begin{tabular}{|c|c|c|c|c|c|c|c|c|c|c|c|c|c|c|c|c|c|c|c|c|}
\hline $\begin{array}{l}\text { Site: } \\
\text { Core, section: } \\
\text { Interval (cm): } \\
\text { Zone: }\end{array}$ & \multicolumn{4}{|c|}{$\begin{array}{c}858 \mathrm{~A} \\
18 X-1 \\
116-118 \\
\mathrm{IVb}\end{array}$} & \multicolumn{4}{|c|}{$\begin{array}{c}858 \mathrm{~A} \\
20 \mathrm{X}-4 \\
100-103 \\
\mathrm{IVb}\end{array}$} & \multicolumn{5}{|c|}{$\begin{array}{c}858 \mathrm{~A} \\
21 \mathrm{X}-3 \\
57-59 \\
\mathrm{IVb}\end{array}$} & \multicolumn{3}{|c|}{$\begin{array}{l}858 \mathrm{~A} \\
24 \mathrm{X}-1 \\
33-35 \\
\text { IIIb }\end{array}$} & $\begin{array}{c}858 \mathrm{~A} \\
24 \mathrm{X}-1 \\
33-35 \\
\text { IIIb }\end{array}$ & \multicolumn{3}{|c|}{$\begin{array}{c}858 \mathrm{~A} \\
25 \mathrm{X}-1 \\
29-32 \\
11 \mathrm{~b}\end{array}$} \\
\hline $\begin{array}{l}\mathrm{Si} \\
\mathrm{Al}^{\mathrm{IV}} \\
\mathrm{S}_{\text {tet. }}\end{array}$ & $\begin{array}{l}6.070 \\
1.930 \\
8.000\end{array}$ & $\begin{array}{l}7.514 \\
0.486 \\
8.000\end{array}$ & $\begin{array}{l}6.336 \\
1.664 \\
8.000\end{array}$ & $\begin{array}{l}6.760 \\
1.240 \\
8.000\end{array}$ & $\begin{array}{l}6.360 \\
1.640 \\
8.000\end{array}$ & $\begin{array}{l}7.275 \\
0.725 \\
8.000\end{array}$ & $\begin{array}{l}6.626 \\
1.374 \\
8.000\end{array}$ & $\begin{array}{l}6.325 \\
1.675 \\
8.000\end{array}$ & $\begin{array}{l}5.944 \\
2.056 \\
8.000\end{array}$ & $\begin{array}{l}6.693 \\
1.307 \\
8.000\end{array}$ & $\begin{array}{l}5.969 \\
2.031 \\
8.000\end{array}$ & $\begin{array}{l}6.891 \\
1.109 \\
8.000\end{array}$ & $\begin{array}{l}6.221 \\
1.779 \\
8.000\end{array}$ & $\begin{array}{l}5.944 \\
2.056 \\
8.000\end{array}$ & $\begin{array}{l}6.061 \\
1.939 \\
8.000\end{array}$ & $\begin{array}{l}6.592 \\
1.408 \\
8.000\end{array}$ & $\begin{array}{l}6.007 \\
1.993 \\
8.000\end{array}$ & $\begin{array}{l}6.293 \\
1.707 \\
8.000\end{array}$ & $\begin{array}{l}7.831 \\
0.169 \\
8.000\end{array}$ & $\begin{array}{l}6.718 \\
1.282 \\
8.000\end{array}$ \\
\hline $\begin{array}{l}\mathrm{Al} \\
\mathrm{TI} \\
\mathrm{Fe} \\
\mathrm{Mn} \\
\mathrm{Mg} \\
\mathrm{Zn} \\
\Sigma \text { oct. }\end{array}$ & $\begin{array}{l}1.977 \\
0.040 \\
1.265 \\
0.023 \\
2.194 \\
0.022 \\
5.523\end{array}$ & $\begin{array}{l}2.460 \\
0.019 \\
0.610 \\
0.016 \\
1.099 \\
0.000 \\
4.203\end{array}$ & $\begin{array}{l}1.703 \\
0.243 \\
1.271 \\
0.033 \\
2.119 \\
0.000 \\
5.369\end{array}$ & $\begin{array}{l}2.134 \\
0.074 \\
0.940 \\
0.016 \\
1.820 \\
0.010 \\
4.994\end{array}$ & $\begin{array}{l}1.873 \\
0.024 \\
1.365 \\
0.024 \\
2.143 \\
0.020 \\
5.448\end{array}$ & $\begin{array}{l}2.031 \\
0.022 \\
0.931 \\
0.012 \\
1.920 \\
0.008 \\
4.925\end{array}$ & $\begin{array}{l}1.883 \\
0.059 \\
1.047 \\
0.015 \\
2.215 \\
0.000 \\
5.219\end{array}$ & $\begin{array}{l}1.840 \\
0.014 \\
1.211 \\
0.025 \\
2.409 \\
0.014 \\
5.511\end{array}$ & $\begin{array}{l}1.810 \\
0.016 \\
1.094 \\
0.030 \\
2.737 \\
0.020 \\
5.705\end{array}$ & $\begin{array}{l}1.870 \\
0.036 \\
0.937 \\
0.018 \\
2.243 \\
0.003 \\
5.107\end{array}$ & $\begin{array}{l}1.682 \\
0.024 \\
1.213 \\
0.023 \\
2.805 \\
0.017 \\
5.765\end{array}$ & $\begin{array}{l}1.862 \\
0.015 \\
0.943 \\
0.023 \\
2.292 \\
0.016 \\
5.151\end{array}$ & $\begin{array}{l}2.172 \\
0.016 \\
0.958 \\
0.017 \\
2.276 \\
0.000 \\
5.438\end{array}$ & $\begin{array}{l}1.429 \\
0.012 \\
1.238 \\
0.041 \\
3.069 \\
0.010 \\
5.799\end{array}$ & $\begin{array}{l}1.572 \\
0.008 \\
1.418 \\
0.047 \\
2.842 \\
0.000 \\
5.886\end{array}$ & $\begin{array}{l}1.937 \\
0.006 \\
1.266 \\
0.027 \\
1.799 \\
0.005 \\
5.040\end{array}$ & $\begin{array}{l}1.525 \\
0.007 \\
1.899 \\
0.035 \\
2.479 \\
0.004 \\
5.950\end{array}$ & $\begin{array}{l}2.545 \\
0.015 \\
0.748 \\
0.027 \\
0.858 \\
0.008 \\
4.201\end{array}$ & $\begin{array}{l}2.262 \\
0.007 \\
0.975 \\
0.015 \\
1.305 \\
0.001 \\
4.565\end{array}$ & $\begin{array}{l}1.969 \\
0.007 \\
1.229 \\
0.031 \\
1.671 \\
0.001 \\
4.908\end{array}$ \\
\hline $\begin{array}{l}\mathrm{Ca} \\
\mathrm{Na} \\
\mathrm{K} \\
\Sigma \text { interl. }\end{array}$ & $\begin{array}{l}0.056 \\
0.207 \\
0.477 \\
0.740\end{array}$ & $\begin{array}{l}0.142 \\
1.042 \\
0.239 \\
1.423\end{array}$ & $\begin{array}{l}0.063 \\
0.268 \\
0.323 \\
0.654\end{array}$ & $\begin{array}{l}0.043 \\
0.292 \\
0.578 \\
0.913\end{array}$ & $\begin{array}{l}0.029 \\
0.342 \\
0.422 \\
0.793\end{array}$ & $\begin{array}{l}0.036 \\
0.361 \\
0.368 \\
0.765\end{array}$ & $\begin{array}{l}0.042 \\
0.356 \\
0.463 \\
0.861\end{array}$ & $\begin{array}{l}0.045 \\
0.263 \\
0.402 \\
0.710\end{array}$ & $\begin{array}{l}0.043 \\
0.121 \\
0.558 \\
0.722\end{array}$ & $\begin{array}{l}0.045 \\
0.502 \\
0.543 \\
1.090\end{array}$ & $\begin{array}{l}0.036 \\
0.110 \\
0.589 \\
0.735\end{array}$ & $\begin{array}{l}0.111 \\
0.100 \\
0.549 \\
0.760\end{array}$ & $\begin{array}{l}0.014 \\
0.078 \\
0.594 \\
0.686\end{array}$ & $\begin{array}{l}0.049 \\
0.479 \\
0.429 \\
0.957\end{array}$ & $\begin{array}{l}0.071 \\
0.322 \\
0.107 \\
0.500\end{array}$ & $\begin{array}{l}0.033 \\
1.238 \\
0.075 \\
1.346\end{array}$ & $\begin{array}{l}0.053 \\
0.181 \\
0.245 \\
0.479\end{array}$ & $\begin{array}{l}0.134 \\
2.232 \\
0.231 \\
2.597\end{array}$ & $\begin{array}{l}0.046 \\
0.306 \\
0.357 \\
0.709\end{array}$ & $\begin{array}{l}0.078 \\
0.951 \\
0.366 \\
1.396\end{array}$ \\
\hline $\mathrm{Si} / \mathrm{Al}$ & 1.55 & 2.55 & 1.88 & 2.00 & 1.81 & 2.64 & 2.03 & 1.80 & 1.54 & 2.11 & 1.61 & 2.32 & 1.57 & 1.71 & 1.73 & 1.97 & 1.71 & 1.48 & 3.22 & 2.07 \\
\hline
\end{tabular}




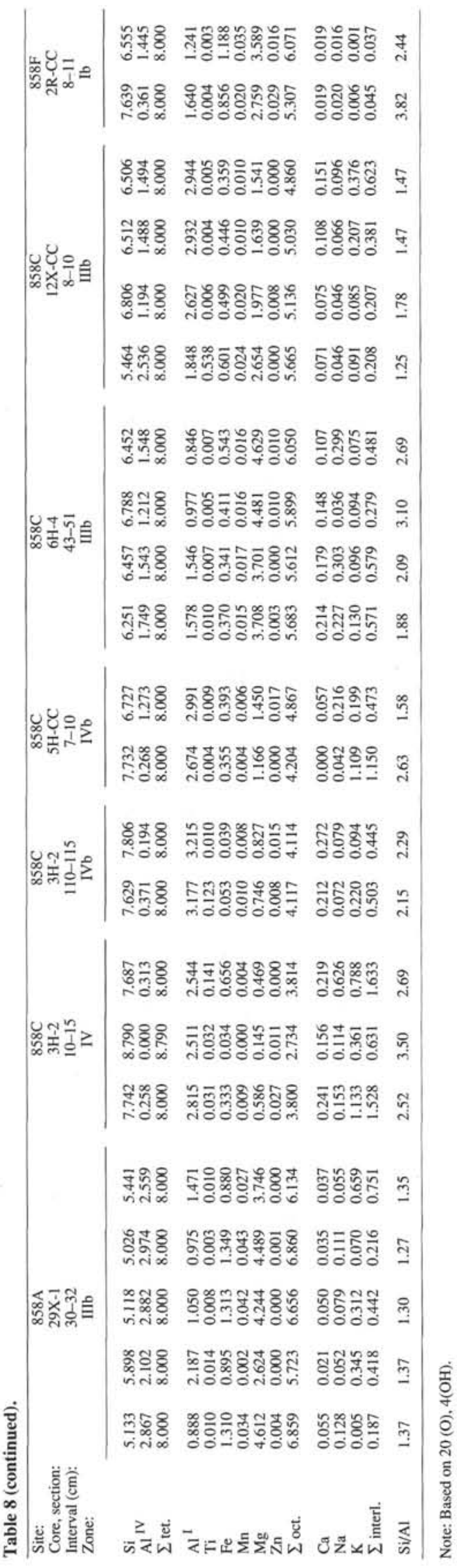

plagioclase to albite (Table 3; Fig. 12C). Authigenic clays are dominated by chlorite (Pl. 5, Fig. 1) and micas are trace to absent below 612 mbsf in Hole 857D (Table 14), consistent with low sediment $\mathrm{K}_{2} \mathrm{O}$ contents (Goodfellow et al., this volume). Authigenic epidote is euhedral to anhedral, commonly abundant (up to $30 \mathrm{vol} \%$ ) and shows no relationship to the grain-size of the host sediment. Sphene is present below 440 mbsf as anhedral crystals and fine-grained xenoblastic aggregates up to $75 \mu \mathrm{m}$ in diameter, and forms up to $5 \mathrm{vol} \%$. Pyrite is abundant (Table 14) and coarser grained at the bottom of Hole 857C and in Hole 857D. It occurs as disseminated euhedral to anhedral and corroded crystals in concentrations up to 5 vol\% (Pl. 5, Figs. 2 and 3 ). Pyrite also occurs with pyrrhotite, chalcopyrite, and sphalerite in veins crosscutting altered sediment in Hole 857D (Fig. 11). Sphalerite and chalcopyrite occur in veins as anhedral masses up to $15 \mathrm{~mm}$ in diameter (Davis, Mottl, Fisher, et al., 1992).

Zone Ic

This zone occurs between 628 and $736 \mathrm{mbsf}$ in Hole 857D and consists of quartz-wairakite-epidote (Fig. 11). Quartz-wairakite-epidoteactinolite veins also occur in mafic sills between 522 and 740 mbsf (Davis, Mottl, Fisher, et al., 1992).

Euhedral quartz (up to $250 \mu \mathrm{m}$ in diameter) occurs with epidote \pm wairakite and sulfides in veins and vugs below $580 \mathrm{mbsf}$ in Hole 857D. Wairakite is present in veins cutting sediments between 628 and 736 mbsf and mafic sills within Hole 857C and 857D (Davis, Mottl, Fisher, et al., 1992). Wairakite crystals up to $2 \mathrm{~mm}$ in diameter are typically twinned, equant, and commonly euhedral to subhedral (Pl. 5, Fig. 4). Wairakite approaches $\mathrm{Ca}$ end-member compositions $(\mathrm{Ca} / \mathrm{Ca}+\mathrm{Na}=0.942-0.996$; Table 13). Euhedral epidote also occurs in quartz \pm wairakite veins (Table 14; Pl. 5, Figs. 5 and 6) and is more $\mathrm{Al}$-rich and Fe-poor than detrital epidote (Fig. 13). Pyrite occurs as disseminated euhedral to subhedral crystals and in veins with pyrrhotite, quartz \pm epidote \pm wairakite.

\section{DISCUSSION}

Sites $856(\mathrm{BH})$ and $858(\mathrm{AAV})$ are hydrothermal upflow zones with distinct mineral assemblages and mineral zonation patterns (Table 5; Figs. 14 and 18). Both upflow systems are characterized by variably altered and indurated hemipelagic and turbiditic sediments. The hydrothermal alteration zones have a convex-upward geometry (Figs. 14 and 18). The BH upflow zone represents a fossil hydrothermal system associated with a massive sulfide deposit that was penetrated to a depth of $94 \mathrm{mbsf}$ in Hole $856 \mathrm{H}$. The hydrothermal upflow zone at AAV (Site 858) is associated with $184^{\circ}-276^{\circ} \mathrm{C}$ vents (Davis, Mottl, Fisher, et al., 1992). These temperatures are similar to fluid inclusion trapping temperatures in anhydrite and wairakite (from Zone IIIb and $\mathrm{Ib}$, respectively) from the most intensely altered sediments at AAV (Peter et al., this volume).

\section{Bent Hill (Site 856)}

The sediments in Holes $856 \mathrm{~A}$ and $856 \mathrm{~B}$ reflect hydrothermal alteration associated with the inactive $\mathrm{BH}$ massive sulfide deposit. The core of the hydrothermal discharge conduit (Zone Ia) occurs between 110 and 118 mbsf in Hole 856B adjacent to the $\mathrm{BH}$ massive sulfide deposit (Figs. 4 and 14; Table 5). In Zone Ia, hemipelagic and turbiditic sediment are bleached to pale blue grey, silicified, fractured and brecciated, and cut by pyrrhotite-chalcopyrite veins. The original detrital sedimentary mineralogy has been replaced in Zone Ia by a quartz(Fe)chlorite-muscovite-rutile-chalcopyrite-pyrrhotite assemblage ( $\mathrm{Pl}$. 1, Figs. 1-6). The intensity of sediment alteration in Zone Ia is also evident from the sediment chemistry, in which $\mathrm{Si}$ and $\mathrm{Fe}$ are enriched and $\mathrm{Ca}$ and $\mathrm{Na}$ are depleted relative to unaltered sediment (Goodfellow and Peter, this volume).

The pyrrhotite-sphalerite(wurtzite)-isocubanite massive sulfide assemblage at $\mathrm{BH}$ suggests hydrothermal fluid temperatures $>350^{\circ} \mathrm{C}$ 
MI. LEYBOURNE, W.D. GOODFELLOW

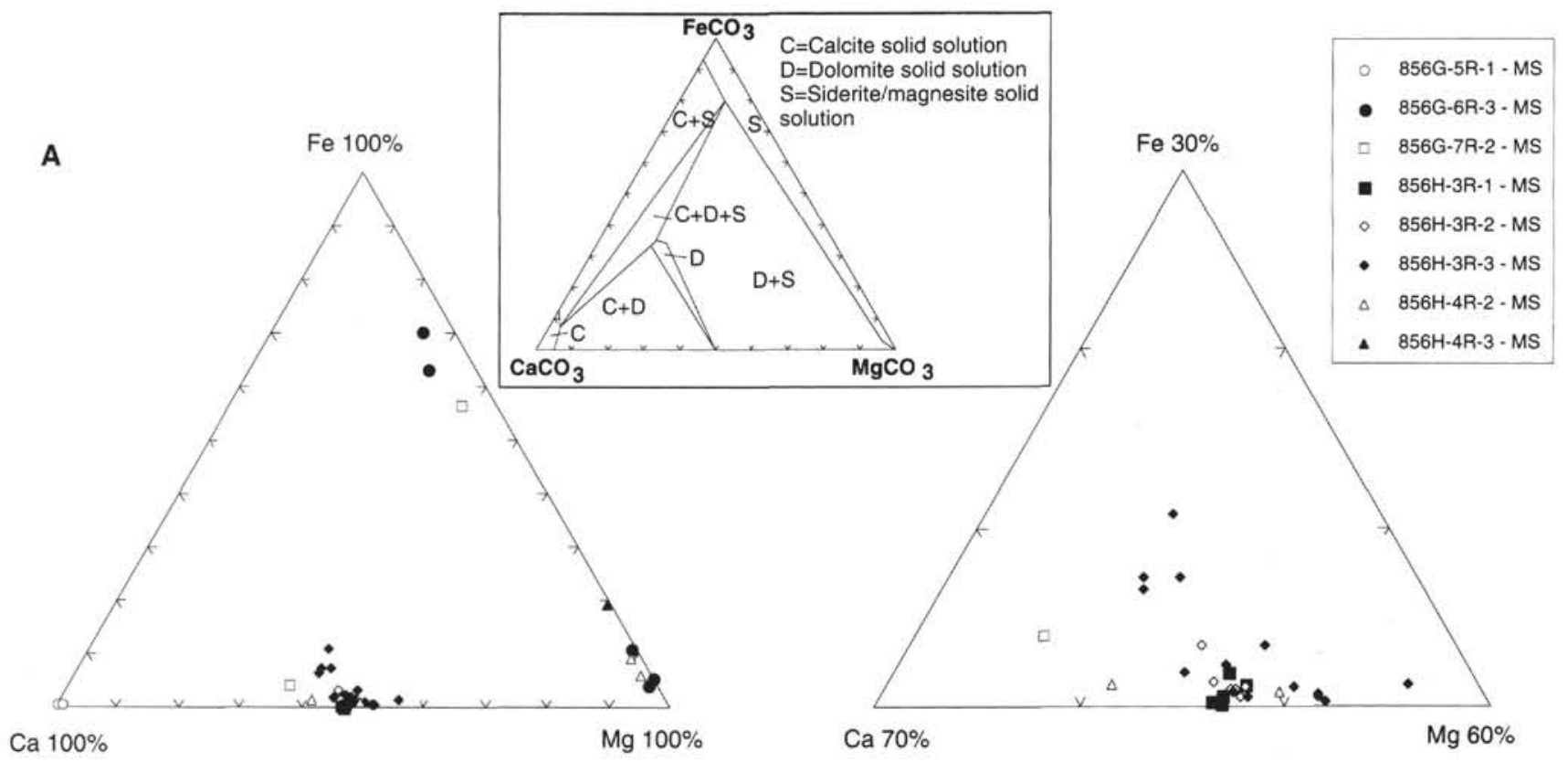

Fe $100 \%$

B

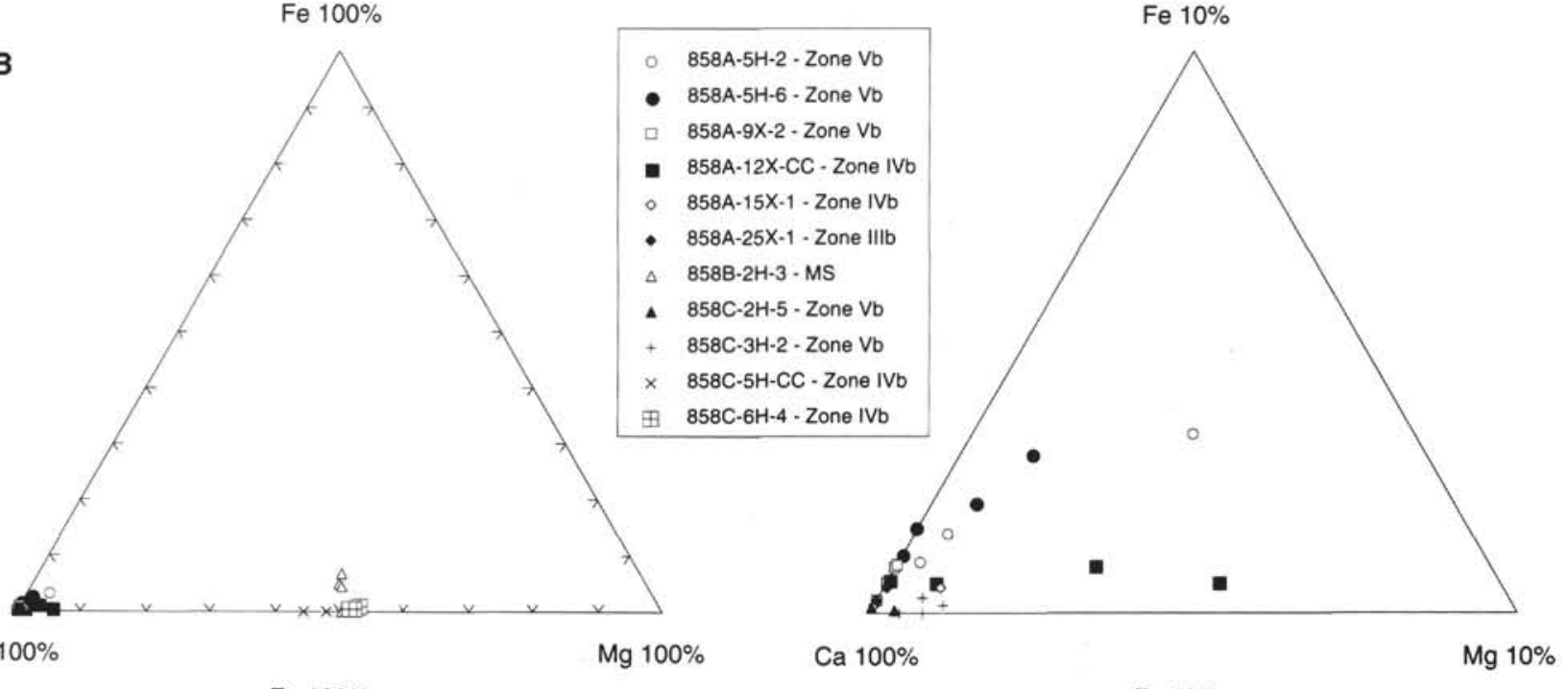

Fe $100 \%$

Fe $10 \%$

C

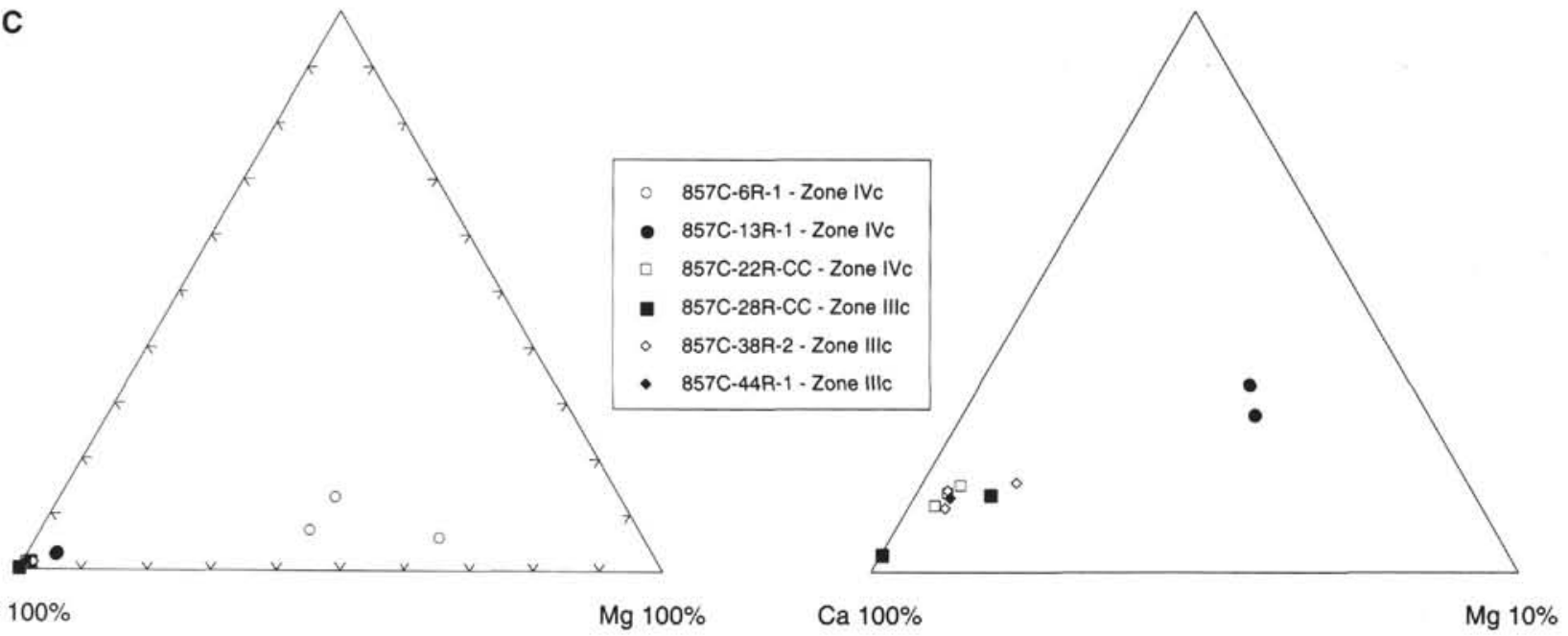

Figure 17. Ternary $\mathrm{CaCO}_{3}-\mathrm{FeCO}_{3}-\mathrm{MgCO}_{3}$ diagram of carbonate minerals. A. Site 856. B. Site 858. C. Site 857. Inset plot with compositional fields after Rosenberg (1967). Data from Table 11.

188 
Table 9. Electron microprobe data for authigenic talc, serpentine, and saponite interstitial to massive sulfide, Leg 139.

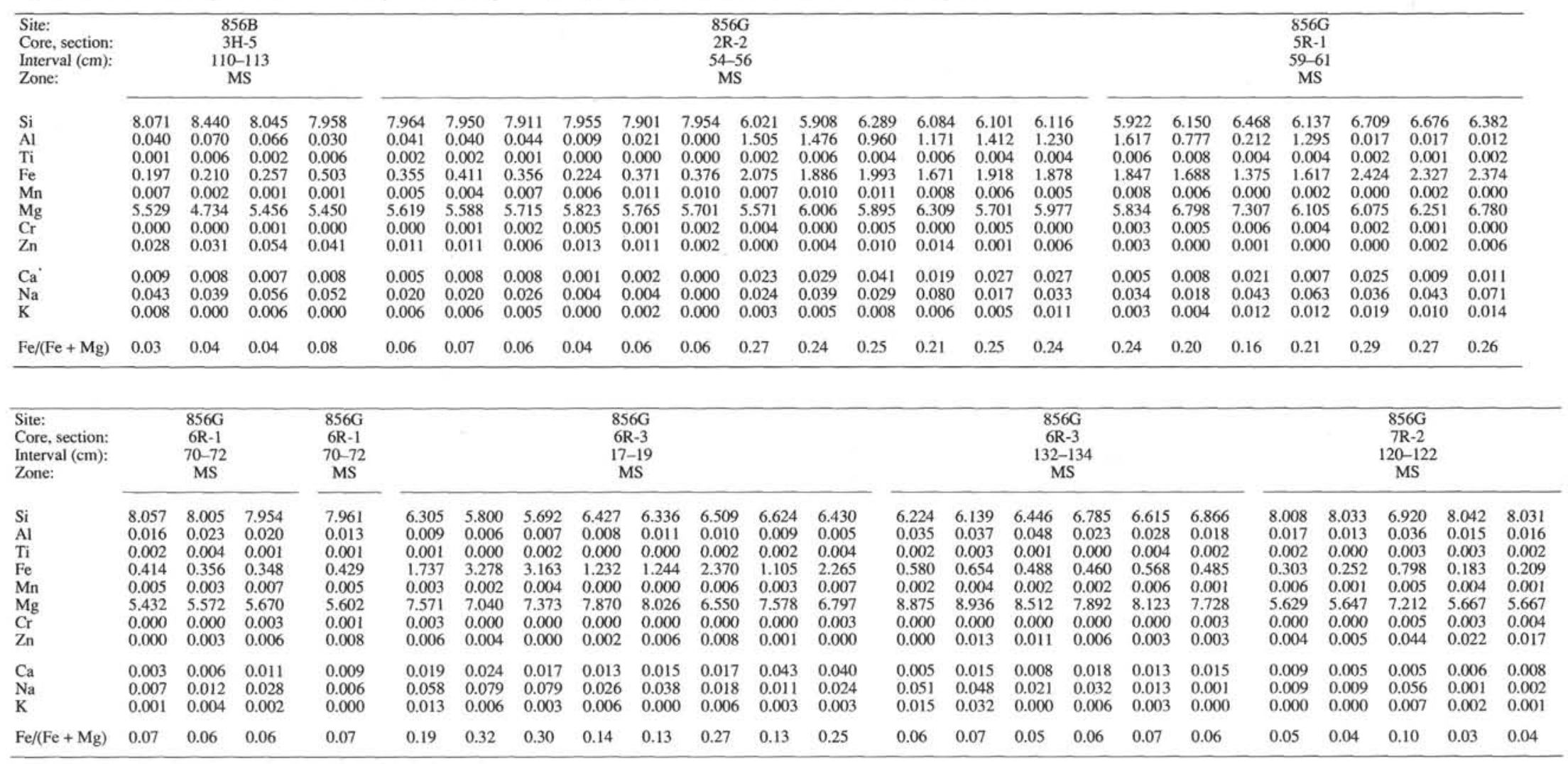


Table 9 (continued).

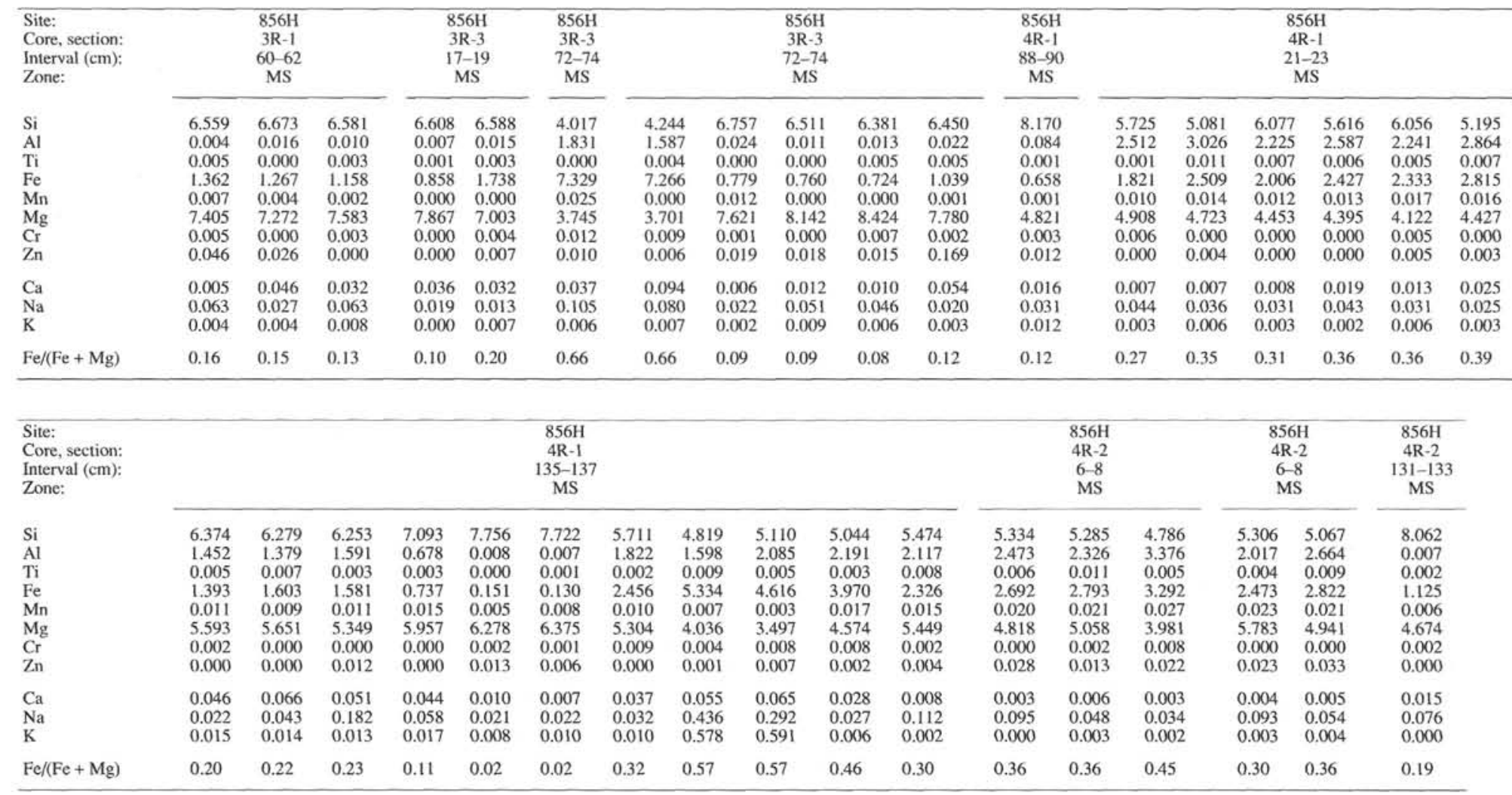




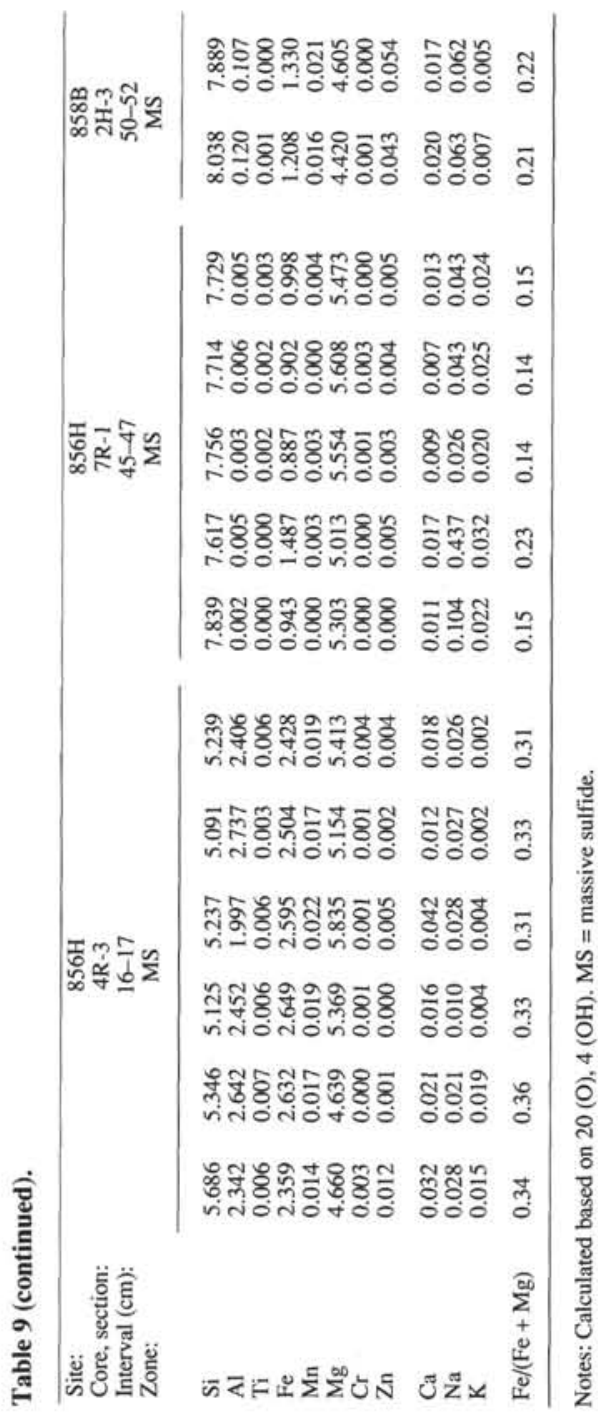

(Goodfellow and Franklin, in press). These temperatures generally agree with fluid inclusion trapping temperatures ranging up to $338^{\circ} \mathrm{C}$ in quartz from Zone Ia (Peter et al., this volume). Calculated temperatures of authigenic chlorite in Zone Ia range from $175^{\circ}-410^{\circ} \mathrm{C}$ using the geothermometer of Cathelineau (1988) and are similar to fluid inclusion trapping temperatures in coexisting quartz $\left(181^{\circ}-338^{\circ} \mathrm{C}\right.$; Peter et al., this volume). The Fe contents of the chlorites in Zone Ia generally increase with increasing temperature (based on $\mathrm{Al}^{\mathrm{IV}}$ ) (Fig. 16), indicating a dependence of $\mathrm{Fe}$ content on temperature for authigenic chlorite (Cathelineau, 1988). The Fe-rich character of the chlorite in Zone Ia is consistent with formation from a high-temperature, end-member hydrothermal fluid (Mottl et al., 1979; Seewald et al., 1990; Von Damm, 1990). The small amounts of $\mathrm{Mg}$ in the chlorites originated either from $\mathrm{Mg}$ present in the precursor sediment or from the entrainment of minor amounts of seawater into the center of fluid upflow.

The composition of the high-temperature end-member hydrothermal fluid is further constrained by the formation of authigenic rutile (Zones Ia and $\Pi \mathrm{a}$ ) rather than another Ti-bearing mineral such as sphene. The hydrothermal mineralogy (quartz-chlorite-muscovite) in the core of the $\mathrm{BH}$ upflow zone is distinctly different from the alteration assemblage (wairakite-epidote-sphene) near the center of fluid upflow at AAV. The absence of epidote or any other Ca-mineral in Zone $\mathrm{Ia}$ and low bulk-rock $\mathrm{CaO}$ contents (Goodfellow and Peter, this volume) indicates that calcic minerals were destroyed by hydrothermal alteration.

The high-temperature, primary sulfide assemblage at $\mathrm{BH}$ is commonly overprinted by a later, lower temperature pyrite-(low-Fe)sphalerite-chalcopyrite-magnetite assemblage that probably formed at temperatures between $210^{\circ}$ and $280^{\circ} \mathrm{C}$, based on fluid inclusion trapping temperatures in low-Fe sphalerite (Peter et al., this volume). These temperatures overlap vent fluid temperatures of $184^{\circ}-276^{\circ} \mathrm{C}$ at AAV and $264^{\circ} \mathrm{C}$ at $\mathrm{BH}$ (Goodfellow and Franklin, in press). The BH massive sulfide formed, therefore, from an earlier high-temperature, metalliferous fluid rather than lower-temperature, metal-poor fluids venting south of BH (Butterfield et al., this volume). Chlorite adjacent to mineralized veins in Zone Ia is commonly more Mg-rich than chlorite removed from the veins (Figs. 15A,B and 16), suggesting that the chalcopyrite $+\mathrm{Mg}$-chlorite vein mineralization was produced by a later, lower-temperature hydrothermal fluid with a greater seawater component than the high-temperature fluid from which the quartz-Fechlorite-illite/muscovite assemblage precipitated.

Sediments in hydrothermal alteration zones surrounding the core (Zone Ia) are less intensely altered and brecciated. Unlike Zone Ia, where detrital plagioclase is destroyed, plagioclase in Zone IIa is altered to albite. Furthermore, higher $\mathrm{Mg} / \mathrm{Mg}+\mathrm{Fe}$ ratios for hydrothermal chlorite and illite/muscovite (Fig. 15) in Zone IIa is consistent with lower temperatures and greater interaction of $\mathrm{Mg}$-bearing seawater with the upwelling hydrothermal fluid. Mixing between seawater and hydrothermal fluid is also indicated by the dominance of $\mathrm{Mg}$ - carbonates (dolomite, magnesite, and siderite; Fig. 17). High$\mathrm{Mg}$ silicates (talc, serpentine, saponite, and chlorite) are also associated with massive sulfide and sulfide sediment in Holes $856 \mathrm{G}$ and $856 \mathrm{H}$ and are consistent with rapid mixing between hydrothermal fluid and seawater (Goodfellow et al., in press).

Zones III a and IVa in Holes 856A and 856B are characterized by anhydrite and calcite, respectively. The mineralogy of these zones is consistent with precipitation from entrained seawater that mixed with and was heated by outward-flowing hydrothermal fluid. The low sulfate content of end-member hydrothermal fluids (Von Damm, 1990; Lydon et al., 1992; Butterfield et al., this volume) indicates that all the sulfate was derived from entrained seawater, whereas a component of the Ca probably originated from the hydrothermal breakdown of plagioclase, detrital epidote, and biogenic calcite in Zones Ia and IIa (Goodfellow and Peter, in press). Fluid flow in Zones Ia and IIa is largely fracture controlled, whereas in Zones IIIa and IVa, it is focussed along permeable turbidites. As a result, the cross-stratal permeability in Zones IIIa and IVa is relatively low. The common occur- 
Table 10. Electron microprobe data for sulfate minerals in hydrothermally altered hemipelagic and turbiditic sediment and interstitial to massive sulfide, Leg 139.

\begin{tabular}{|c|c|c|c|c|c|c|c|c|c|c|c|c|c|}
\hline $\begin{array}{l}\text { Site: } \\
\text { Core, section: } \\
\text { Interval }(\mathrm{cm}): \\
\text { Zone: } \\
\text { Type: }\end{array}$ & & $\begin{array}{l}\text { SD } \\
-1 \\
-17 \\
\text { S } \\
a\end{array}$ & & & $\begin{array}{c}856 \mathrm{E} \\
1 \mathrm{H}-1 \\
48-50 \\
\mathrm{MS} \\
\mathrm{Ba}\end{array}$ & & & $\begin{array}{c}858 \\
15 \mathrm{X} \\
35-3 \\
\text { IVt } \\
\text { An }\end{array}$ & & & $\begin{array}{c}858 \mathrm{~A} \\
18 \mathrm{X}-1 \\
116-118 \\
\mathrm{IVb} \\
\mathrm{An}\end{array}$ & & \\
\hline $\mathrm{CaO}$ & 0.06 & 0.04 & 0.03 & 0.03 & 0.04 & 0.09 & 0.31 & 39.5 & & 40.55 & 40.44 & 39.51 & 39.79 \\
\hline $\mathrm{MgO}$ & 0.00 & 0.00 & 0.00 & 0.00 & 0.00 & 0.00 & & 0.0 & & 0.00 & 0.00 & 0.00 & 0.00 \\
\hline $\mathrm{BaO}$ & 61.96 & 61.96 & 65.06 & 65.41 & 64.10 & 62.72 & 61.10 & 0.0 & & 0.03 & 0.00 & 0.00 & 0.27 \\
\hline $\mathrm{FeO}$ & 0.03 & 0.06 & 0.06 & 0.07 & 0.03 & 0.05 & 0.00 & 0.0 & & 0.00 & 0.07 & 0.17 & 0.05 \\
\hline $\mathrm{ZnO}$ & 0.29 & 0.00 & 0.02 & 0.00 & 0.00 & 0.00 & 0.00 & 0.0 & & 0.00 & 0.00 & 0.00 & 0.03 \\
\hline $\mathrm{SrO}$ & 3.17 & 3.03 & 2.05 & 1.17 & 1.91 & 2.54 & 3.64 & 0.1 & & 0.06 & 0.14 & 0.11 & 0.15 \\
\hline $\mathrm{MnO}$ & 0.06 & 0.00 & 0.00 & 0.00 & 0.00 & 0.06 & 0.00 & 0.0 & & 0.02 & 0.03 & 0.00 & 0.03 \\
\hline $\mathrm{SO}_{3}$ & 31.90 & 35.13 & 34.77 & 34.57 & 34.82 & 34.55 & 34.63 & 59.5 & & 60.47 & 60.92 & 58.60 & 60.57 \\
\hline $\mathrm{SiO}_{2}$ & 0.10 & 0.06 & 0.09 & 0.01 & 0.04 & 0.05 & 0.05 & 0.0 & & 0.00 & 0.01 & 0.05 & 0.00 \\
\hline Total & 97.55 & 100.29 & 102.06 & 101.25 & 100.94 & 100.05 & 99.74 & 99.4 & & 101.13 & 101.60 & 98.45 & 100.90 \\
\hline Site: & \multirow{2}{*}{\multicolumn{2}{|c|}{$858 \mathrm{~A}$}} & \multirow{2}{*}{\multicolumn{2}{|c|}{$\begin{array}{l}858 \mathrm{~A} \\
24 \mathrm{X}-1\end{array}$}} & $858 \mathrm{~A}$ & \multirow{2}{*}{\multicolumn{2}{|c|}{$858 \mathrm{~A}$}} & \multirow{2}{*}{\multicolumn{4}{|c|}{$\begin{array}{l}858 \mathrm{C} \\
6 \mathrm{H}-4\end{array}$}} & \multirow{2}{*}{\multicolumn{2}{|c|}{$858 \mathrm{C}$}} \\
\hline Core, section: & & & & & $29 \mathrm{X}-1$ & & & & & & & & \\
\hline Interval $(\mathrm{cm})$ : & \multicolumn{2}{|c|}{$\begin{array}{l}21 X-3 \\
57-59\end{array}$} & \multicolumn{2}{|c|}{$33-35$} & $30-32$ & \multicolumn{2}{|c|}{$29 X-1$} & \multicolumn{4}{|c|}{$\begin{array}{c}6 \mathrm{H}-4 \\
43-51 \mathrm{a}\end{array}$} & \multicolumn{2}{|c|}{$\begin{array}{c}12 \mathrm{X}-\mathrm{CC} \\
8-10\end{array}$} \\
\hline Zone: & \multirow{2}{*}{\multicolumn{2}{|c|}{$\begin{array}{l}\text { IVb } \\
\mathrm{An}\end{array}$}} & \multirow{2}{*}{\multicolumn{2}{|c|}{$\begin{array}{l}\underset{\text { IIIb }}{\text { An }} \\
\text {. }\end{array}$}} & IIIIb & \multirow{2}{*}{\multicolumn{2}{|c|}{$\begin{array}{l}\text { IIIb } \\
\text { An }\end{array}$}} & & II & lb & & & \\
\hline Type: & & & & & An & & & & A & n & & & \\
\hline $\mathrm{CaO}$ & 38.98 & 39.21 & 38.56 & 39.35 & 39.69 & 40. & & 39.03 & 39.14 & 39.49 & 39.96 & 38.91 & 39.72 \\
\hline $\mathrm{MgO}$ & 0.00 & 0.00 & 0.00 & 0.00 & 0.00 & & & 0.00 & 0.00 & 0.00 & 0.00 & 0.00 & 0.00 \\
\hline $\mathrm{BaO}$ & 0.02 & 0.00 & 0.00 & 0.06 & 0.06 & & & 0.00 & 0.00 & 0.00 & 0.07 & 0.13 & 0.07 \\
\hline $\mathrm{FeO}$ & 0.08 & 0.09 & 0.15 & 0.02 & 0.00 & & & 0.07 & 0.03 & 0.08 & 0.02 & 0.05 & 0.00 \\
\hline $\mathrm{ZnO}$ & 0.22 & 0.05 & 0.00 & 0.00 & 0.02 & & 59 & 0.08 & 0.00 & 0.21 & 0.00 & 0.00 & 0.02 \\
\hline SrO & 0.09 & 0.18 & 0. & & 0.00 & & & 0.06 & 0.08 & 0.08 & 0.1 & 0.18 & 0.31 \\
\hline $\mathrm{MnO}$ & 0.00 & & & & 0.00 & & & 0.02 & 0.00 & & 0. & 0.02 & 0.05 \\
\hline So & 61.10 & & 60.49 & 60.92 & 59.51 & 59. & & 58.04 & 58.63 & 58.28 & 58.15 & 49.95 & 58.82 \\
\hline $\mathrm{SiO}_{2}$ & 0.02 & 0.02 & 0.02 & 0.06 & 0.01 & & & 0.01 & 0.03 & 0.05 & 0.01 & 0.02 & 0.02 \\
\hline Total & 100.50 & 100.34 & 99.33 & 100.54 & 99.29 & 100. & & 97.30 & 97.91 & 98.25 & 98.34 & 89.25 & 99.00 \\
\hline
\end{tabular}

Note: $\mathrm{Ba}=$ barite; $\mathrm{An}=$ anhydrite; $\mathrm{MS}=$ massive sulfide. 
Table 11. Electron microprobe data for carbonate minerals hydrothermally altered hemipelagic and turbiditic sediment and interstitial to massive sulfide, Leg 139 .

\begin{tabular}{|c|c|c|c|c|c|c|c|c|c|c|c|c|c|c|c|}
\hline $\begin{array}{l}\text { Site: } \\
\text { Core, section: } \\
\text { Interval }(\mathrm{cm}) \text { : } \\
\text { Zone: } \\
\text { Type: }\end{array}$ & & & & $\begin{array}{l}\text { G } \\
-3 \\
19 \\
\text { S } \\
\text { i }\end{array}$ & & $\begin{array}{c}856 \mathrm{G} \\
6 \mathrm{R}-3 \\
132-13 \\
\mathrm{MS} \\
\mathrm{Mg}\end{array}$ & & $\begin{array}{r}8 \\
7 \\
120 \\
\mathrm{Si}\end{array}$ & $\begin{array}{l}\mathrm{G} \\
2 \\
122 \\
S^{2} \\
\text { Do }\end{array}$ & & & & & & \\
\hline $\begin{array}{l}\mathrm{CaO} \\
\mathrm{MgO} \\
\mathrm{FeO} \\
\mathrm{MnO} \\
\mathrm{SrO} \\
\mathrm{BaO} \\
\mathrm{ZnO} \\
\mathrm{SO}_{3} \\
\text { Total }\end{array}$ & $\begin{array}{r}52.25 \\
0.07 \\
0.20 \\
0.04 \\
\text { nd } \\
\text { nd } \\
0.00 \\
\text { nd } \\
55.00\end{array}$ & $\begin{array}{c}53.57 \\
0.41 \\
0.26 \\
0.06 \\
\text { nd } \\
\text { nd } \\
0.04 \\
\text { nd } \\
56.19\end{array}$ & $\begin{array}{r}2.76 \\
9.15 \\
46.06 \\
0.09 \\
\text { nd } \\
\text { nd } \\
0.00 \\
\text { nd } \\
58.49\end{array}$ & $\begin{array}{c}4.13 \\
10.88 \\
42.16 \\
0.05 \\
\text { nd } \\
\text { nd } \\
0.02 \\
\text { nd } \\
57.32\end{array}$ & $\begin{array}{r}0.85 \\
46.01 \\
3.74 \\
0.67 \\
\text { nd } \\
\text { nd } \\
0.09 \\
\text { nd } \\
53.23\end{array}$ & $\begin{array}{r}0.64 \\
42.39 \\
9.35 \\
0.79 \\
\text { nd } \\
\text { nd } \\
0.00 \\
\text { nd } \\
53.45\end{array}$ & $\begin{array}{r}0.10 \\
45.98 \\
4.76 \\
0.37 \\
\text { nd } \\
\text { nd } \\
0.00 \\
\text { nd } \\
51.39\end{array}$ & $\begin{array}{r}3.08 \\
14.98 \\
39.91 \\
0.10 \\
\text { nd } \\
\text { nd } \\
0.07 \\
\text { nd } \\
58.89\end{array}$ & $\begin{array}{r}39.22 \\
17.10 \\
3.32 \\
0.06 \\
\text { nd } \\
\text { nd } \\
0.05 \\
\text { nd } \\
59.87\end{array}$ & $\begin{array}{r}30.69 \\
19.60 \\
0.44 \\
0.07 \\
0.06 \\
0.07 \\
0.05 \\
0.01 \\
50.98\end{array}$ & $\begin{array}{r}29.97 \\
19.23 \\
1.44 \\
0.13 \\
0.07 \\
0.00 \\
0.00 \\
0.04 \\
50.88\end{array}$ & $\begin{array}{r}29.94 \\
19.92 \\
0.88 \\
0.08 \\
0.00 \\
0.01 \\
0.05 \\
0.09 \\
50.97\end{array}$ & $\begin{array}{c}30.89 \\
19.21 \\
0.19 \\
0.02 \\
0.05 \\
0.08 \\
0.00 \\
0.25 \\
50.69\end{array}$ & $\begin{array}{r}30.99 \\
19.65 \\
0.14 \\
0.00 \\
0.05 \\
0.02 \\
0.00 \\
0.06 \\
50.91\end{array}$ & $\begin{array}{r}30.88 \\
19.60 \\
0.23 \\
0.01 \\
0.00 \\
0.04 \\
0.04 \\
0.06 \\
50.86\end{array}$ \\
\hline $\begin{array}{l}\mathrm{Ca} \\
\mathrm{Mg} \\
\mathrm{Fe}\end{array}$ & $\begin{array}{r}99.51 \\
0.19 \\
0.30\end{array}$ & $\begin{array}{r}98.60 \\
1.04 \\
0.37\end{array}$ & $\begin{array}{r}5.36 \\
24.74 \\
69.90\end{array}$ & $\begin{array}{r}7.92 \\
29.01 \\
63.08\end{array}$ & $\begin{array}{r}1.25 \\
94.45 \\
4.31\end{array}$ & $\begin{array}{r}0.96 \\
88.13 \\
10.91\end{array}$ & $\begin{array}{r}0.15 \\
94.37 \\
5.48\end{array}$ & $\begin{array}{r}5.59 \\
37.84 \\
56.56\end{array}$ & $\begin{array}{r}59.80 \\
36.25 \\
3.95\end{array}$ & $\begin{array}{r}52.65 \\
46.77 \\
0.58\end{array}$ & $\begin{array}{r}51.81 \\
46.24 \\
1.94\end{array}$ & $\begin{array}{r}51.33 \\
47.50 \\
1.18\end{array}$ & $\begin{array}{l}53.48 \\
46.26 \\
0.26\end{array}$ & $\begin{array}{r}53.04 \\
46.77 \\
0.19\end{array}$ & $\begin{array}{r}52.95 \\
46.74 \\
0.31\end{array}$ \\
\hline
\end{tabular}

\begin{tabular}{|c|c|c|c|c|c|c|c|c|c|c|c|c|c|c|c|c|c|c|c|c|c|c|}
\hline $\begin{array}{l}\text { Site: } \\
\text { Core, section } \\
\text { Interval }(\mathrm{cm}) \\
\text { Zone: } \\
\text { Type: }\end{array}$ & & & & $\begin{array}{c}856 \mathrm{H} \\
3 \mathrm{R}-2 \\
84-87 \\
\text { MS } \\
\text { Do }\end{array}$ & & & & & & & & & & $\begin{array}{c}856 \mathrm{H} \\
3 \mathrm{R}-3 \\
17-19 \\
\text { MS } \\
\text { Do }\end{array}$ & & & & & & $\begin{array}{l}6 \mathrm{H} \\
-3 \\
-74 \\
\mathrm{~S} \\
0\end{array}$ & & \\
\hline $\mathrm{CaO}$ & 28.89 & 30.33 & 29.54 & 29.94 & 29.94 & 30.11 & 30.15 & 28.90 & 30.15 & 29.81 & 30.45 & 28.69 & 31.11 & 30.15 & 31.03 & 29.80 & 26.50 & 29.76 & 29.94 & 29.34 & 28.93 & 29.24 \\
\hline $\mathrm{MgO}$ & 18.01 & 19.59 & 17.96 & 19.56 & 19.90 & 19.84 & 18.33 & 16.68 & 16.07 & 19.04 & 16.23 & 16.14 & 19.32 & 19.61 & 18.31 & 19.91 & 24.35 & 22.83 & 22.96 & 22.81 & 20.00 & 21.40 \\
\hline $\mathrm{FeO}$ & 0.93 & 0.66 & 2.43 & 0.75 & 0.79 & 0.38 & 2.50 & 5.23 & 5.26 & 1.76 & 4.75 & 7.93 & 0.20 & 0.58 & 1.37 & 0.43 & 0.97 & 0.39 & 0.53 & 0.25 & 2.55 & 0.82 \\
\hline $\mathrm{MnO}$ & 0.06 & 0.06 & 0.37 & 0.01 & 0.00 & 0.07 & 0.06 & 0.39 & 0.19 & 0.10 & 0.28 & 0.23 & 0.05 & 0.09 & 0.04 & 0.12 & 0.41 & 0.27 & 0.55 & 0.33 & 1.18 & 0.38 \\
\hline Sro & 0.00 & 0.07 & 0.00 & 0.03 & 0.04 & 0.02 & 0.04 & 0.04 & 0.05 & 0.00 & 0.05 & 0.00 & 0.00 & 0.05 & 0.10 & 0.00 & $\begin{array}{l}0.41 \\
0.04\end{array}$ & 0.00 & 0.03 & 0.05 & $\begin{array}{l}1.10 \\
0.03\end{array}$ & 0.10 \\
\hline $\mathrm{BaO}$ & 0.02 & 0.00 & 0.00 & 0.03 & 0.00 & 0.10 & 0.01 & 0.00 & 0.01 & 0.00 & 0.00 & 0.06 & 0.00 & 0.00 & 0.04 & 0.08 & 0.07 & 0.00 & 0.02 & 0.02 & 0.04 & 0.00 \\
\hline $\mathrm{ZnO}$ & 0.02 & 0.06 & 0.15 & 0.00 & 0.26 & 0.04 & 0.09 & 0.05 & 0.00 & 0.06 & 0.03 & 0.00 & 0.00 & 0.00 & 0.03 & 0.00 & 0.10 & 0.00 & 0.00 & 0.04 & 0.00 & 0.00 \\
\hline $\mathrm{SO}_{3}$ & 0.11 & 0.00 & 0.02 & 0.13 & 0.02 & 0.06 & 0.12 & 0.01 & 0.05 & 0.08 & 0.03 & 0.10 & 0.23 & 0.11 & 0.07 & 0.00 & 0.02 & 0.01 & 0.01 & 0.01 & 0.00 & 0.04 \\
\hline Total & 48.03 & 50.77 & 50.47 & 50.44 & 50.94 & 50.61 & 51.30 & 51.31 & 51.77 & 50.85 & 51.81 & 53.15 & 50.91 & 50.59 & 50.99 & 50.33 & 52.49 & 53.31 & 54.04 & 52.86 & 52.85 & 52.02 \\
\hline $\mathrm{Ca}$ & 52.85 & 52.21 & 52.36 & 51.86 & 51.43 & 51.92 & 52.34 & 51.43 & 53.26 & 51,70 & 53.67 & 50.05 & 53.51 & 52.09 & 53.90 & 51.53 & 43.36 & 48.14 & 48.07 & 47.89 & 49.25 & 49.02 \\
\hline $\mathrm{Mg}$ & 45.82 & 46.90 & 44.28 & 47.12 & 47.52 & 47.57 & 44.27 & 41.30 & 39.49 & 45.92 & 39.80 & 39.16 & 46.22 & 47.13 & 44.24 & 47.89 & 55.41 & 51.36 & 51.27 & 51.79 & 47.37 & 49.91 \\
\hline $\mathrm{Fe}$ & 1.33 & 0.89 & 3.36 & 1.02 & 1.05 & 0.51 & 3.39 & 7.27 & 7.26 & 2.38 & 6.53 & 10.80 & 0.27 & 0.78 & 1.86 & 0.58 & 1.23 & 0.50 & 0.66 & 0.31 & 3.38 & 1.07 \\
\hline
\end{tabular}


Table 11 (continued).

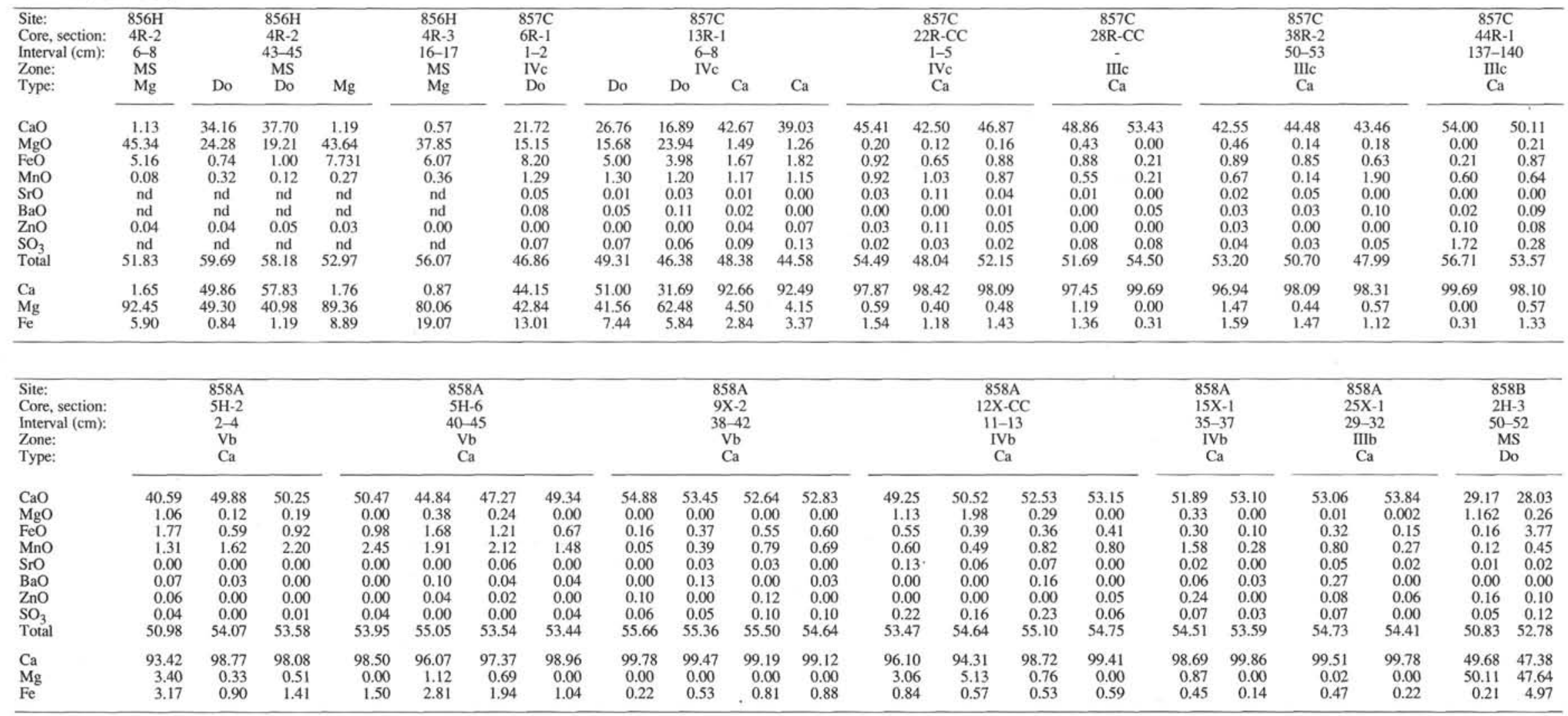




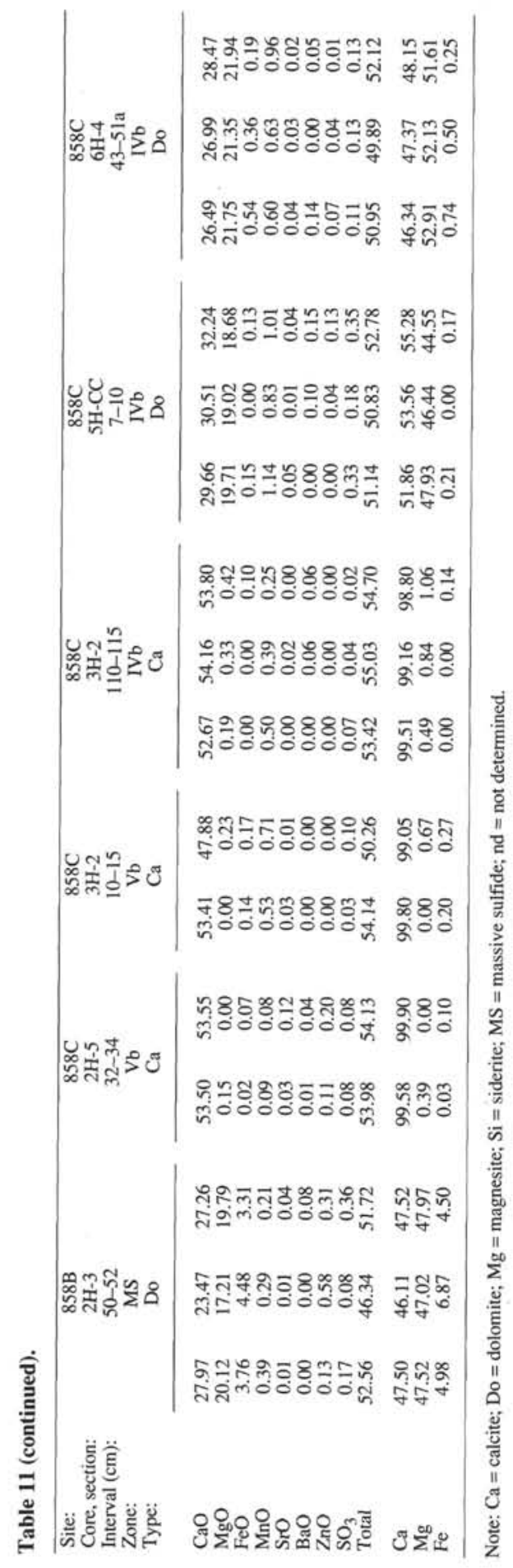

rence of carbonate concretions in or near turbiditic sediments indicates that fluid flow occurred along permeable strata in Zone IVa.

Although Zone Ia is adjacent to a mafic sill (of unknown thickness), the high-temperature alteration is not related to the intrusion of the sill. The sediments immediately adjacent to the sill in Zone Ia-2 (e.g., Sample 139-856B-15X-CC, 20-22 cm) are less intensely altered than those in Zone Ia-1 with albite present in Zone Ia-2 but not in Zone Ia-1. The geochemistry of these subzones supports this interpretation (Goodfellow and Peter, this volume). The sediments in Zone Ia-2 are distinct in containing $\mathrm{Mg}$-smectite (Table 2) and having high $\mathrm{MgO}$ contents (Goodfellow and Peter, this volume). Thus, sill intrusions postdate the high-temperature alteration in Hole 856B. A sill was also intersected at the base of Hole $856 \mathrm{~A}$, but at this site, no hightemperature alteration such as in Zone Ia is observed.

\section{Area of Active Venting (Site 858)}

The AAV (Site 858) is an active hydrothermal system with fluid temperatures up to $276^{\circ} \mathrm{C}$ (Davis, Mottl, Fisher, et al., 1992). The AAV is a lower-temperature hydrothermal system than Bent Hill and is lacking in extensive sulfide mineralization (Goodfellow and Franklin, in press). Temperatures of minerals precipitated near the center of fluid upflow are well constrained by fluid inclusions (Peter et al., this volume) and direct measurements of vent fluids (Goodfellow and Franklin, in press). Hydrothermal minerals at AAV are zoned laterally and vertically about the core of the fluid upflow zone (Fig. 18). Heat flow values (Davis and Villinger, 1992) and pore water compositions (Lydon et al., 1990; Butterfield et al., this volume) are similarly zoned about these hydrothermal vents.

The core of the AAV discharge conduit (Zone Ib) is characterized by highly indurated, brecciated, fractured and veined sediments in Holes $858 \mathrm{D}$ and $858 \mathrm{~F}$. The hydrothermal mineralogy consists of quartz-wairakite-epidote \pm plagioclase-pyrite. Fluid inclusion measurements show that wairakite in Zone Ib formed at temperatures between $250^{\circ}$ and $300^{\circ} \mathrm{C}$ (Peter et al., this volume). These temperatures are consistent with field studies that show wairakite to be stable between $200^{\circ}$ and $320^{\circ} \mathrm{C}$ (Schiffman et al., 1985). Experimental studies (Seyfried et al., 1991) also indicate that AAV feldspar probably formed at temperatures $<325^{\circ} \mathrm{C}$.

The occurrence of anhydrite veins and concretions in Zones Ib and $\mathrm{IIb}$ in Hole $858 \mathrm{~F}$ suggests that hydrothermal fluid conditions fluctuated temporally and spatially at AAV. The occurrence of hightemperature anhydrite $\left(230^{\circ}\right.$ and $311^{\circ} \mathrm{C}$; Peter et al., this volume) below $236 \mathrm{mbsf}$ in Hole 858A indicates that seawater was entrained into the core of the upflow zone and rapidly heated by hydrothermal fluid (Lydon et al., 1992). The occurrence of wairakite at $21.3 \mathrm{mbsf}$ in Hole $858 \mathrm{C}$ near carbonate concretions that formed between $110^{\circ}$ and $250^{\circ} \mathrm{C}$ (Zone $\mathrm{Vb}, 15-17 \mathrm{mbsf}$; Peter et al., this volume) is additional evidence for fluctuating hydrothermal conditions.

The core of the upflow zone at AAV (Zone $\mathrm{Ib}$ ) is surrounded by quartz-epidote-chlorite (Zone IIb). Although the sediments in this zone are brecciated and fractured, the hydrothermal alteration is more pervasive, with epidote comprising up to $20 \mathrm{vol} \%$. The coarse-grained nature of this epidote suggests temperatures up to $300^{\circ} \mathrm{C}$ (Schiffman et al., 1985). The chlorite is somewhat more Mg-rich than chlorite from the high-temperature zone at Site 856 (Zone la and IIa; Figs. 15B and 16), indicating alteration by a mixed seawater and hydrothermal fluid (Goodfellow and Peter, this volume). Zone IIIb (albite-chlorite-pyrite), $\mathrm{IVb}$ (anhydrite-illite-pyrite), and Vb (calcite-illite-pyrite) indicate progressively lower temperatures and intensity of hydrothermal alteration and are consistent with the mixing of entrained seawater with outward migrating hydrothermal fluid (Goodfellow and Peter, this volume). The temperatures of these zones are partly constrained from fluid inclusion temperatures ranging from $230^{\circ}$ to $280^{\circ} \mathrm{C}$ for Zone IIIb and from $112^{\circ}$ to $247^{\circ} \mathrm{C}$ for Zones IVb and Vb (Peter et al., this volume). The temperatures for Zones IVb and $\mathrm{Vb}$ are consistent with temperatures estimated from oxygen isotope data (Goodfellow et al., in press). 
Table 12. Summary of downhole mineralogy, Leg 139.

\begin{tabular}{|c|c|c|c|c|c|c|c|c|c|c|c|c|c|c|c|c|c|c|c|c|c|c|c|c|c|}
\hline \multirow{2}{*}{$\begin{array}{l}\text { Core, section, } \\
\text { Interval (cm) }\end{array}$} & \multirow{2}{*}{$\begin{array}{l}\text { Grain } \\
\text { size }\end{array}$} & \multirow{2}{*}{$\begin{array}{l}\text { Depth } \\
\text { (mbsf) }\end{array}$} & \multicolumn{9}{|c|}{ Detrital } & \multicolumn{14}{|c|}{ Hydrothermal/Authigenic } \\
\hline & & & $Q_{z}$ & Fs & Clay & Micas & $\mathrm{Ch}$ & Ep & Mag & M-F & F-py & Qz & $\mathrm{Ta}$ & Carb & Wa & Ep & $\mathrm{Ru}$ & Sn & $\mathrm{Ba}$ & An & Py & Mr & Po & Cp & Sp \\
\hline \multicolumn{26}{|l|}{$139-858 \mathrm{~A}-$} \\
\hline${ }_{2 \mathrm{H}}^{1 \mathrm{H}-2,5-7}$ & Silty clay & 1.55 & $\mathrm{xxx}$ & $\mathrm{xx}$ & $x x x x x$ & $\mathrm{xxx}$ & $\mathrm{xx}$ & & $\mathrm{x}$ & $x x$ & $\mathrm{x}$ & & & $\mathrm{xx}$ & & & & & & & $\mathrm{x}$ & & & & \\
\hline $\begin{array}{l}2 \mathrm{H}-1,125-127 \\
2 \mathrm{H}-757-59\end{array}$ & $\begin{array}{l}\text { Silty clay } \\
\text { Silve silt }\end{array}$ & 3.65 & $\underset{x x x}{x x y x}$ & $x_{x x}^{x x}$ & $x x x x x$ & $\mathrm{xx}$ & $\mathrm{x}$ & & $x$ & $\mathrm{xx}$ & $x$ & & & & & & & & & & & & & & \\
\hline $\begin{array}{l}2 \mathrm{H}-7,57-59 \\
3 \mathrm{H}-4,29-33\end{array}$ & $\begin{array}{l}\text { Silty clay to silt } \\
\text { Silty clay }\end{array}$ & 11.97 & $\begin{array}{c}x x x x \\
x x y x\end{array}$ & $\begin{array}{c}x x x \\
x x x\end{array}$ & $x_{x x x x}^{x x y x}$ & $x \mathbf{x x}$ & $x x x$ & $x \times x$ & $\mathrm{x}$ & & $\mathrm{x}$ & & & $\mathrm{xx}$ & & & & & & & $\mathrm{x}$ & & & & \\
\hline $\begin{array}{l}3 \mathrm{H}-4,29-33 \\
4 \mathrm{H}-6,68-50\end{array}$ & $\begin{array}{l}\text { Silty clay } \\
\text { Sity clay }\end{array}$ & $\begin{array}{l}16.46 \\
20.38\end{array}$ & $\underset{x x x}{x x x x}$ & $\begin{array}{l}x x x \\
x x x\end{array}$ & 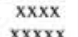 & $x \mathbf{x x}$ & $\mathrm{xx}$ & $\mathrm{x}$ & $\mathrm{x}$ & $\mathrm{x}$ & $\mathrm{x}$ & & & $\mathrm{xx}$ & & & $\mathrm{x}$ & & & & & & & & \\
\hline $\begin{array}{l}4 \mathrm{H}-0,40-30 \\
5 \mathrm{H}-2,2-4\end{array}$ & Silty clay to clayey silt & 32.42 & & $x x x$ & $\underset{x x x x}{x x x}$ & $x x$ & $x x$ & & $x$ & $x \mathbf{x x}$ & $x$ & & & $\begin{array}{c}x x x \\
x x x x x \\
x x x y\end{array}$ & & & $x$ & & & & $\begin{array}{l}x \\
x\end{array}$ & & $x$ & & \\
\hline $5 \mathrm{H}-4,27-30$ & Silt & 35.67 & $\mathrm{xxxxx}$ & $\mathrm{xxx}$ & $x x x$ & $\mathrm{xx}$ & $\mathrm{xxx}$ & $\mathrm{xx}$ & & & & & & $\mathrm{xxxx}$ & & & & & & & $\mathrm{xx}$ & & & & \\
\hline $5 \mathrm{H}-6,40-45$ & Silty clay & 38.80 & & & $x x x$ & $\mathrm{x}$ & $\mathrm{x}$ & & & $x x x$ & & & & $x x x x x$ & & & & & & & & & & & \\
\hline $5 \mathrm{H}-\mathrm{CC}, 10-11$ & Silt & & & & $x x x x$ & $\mathrm{x}$ & $\mathrm{x}$ & & & $\mathrm{xxx}$ & & & & $\mathbf{x x x x x}$ & & & & & & & $\mathrm{x}$ & & & & \\
\hline $6 \mathrm{H}-3,77-79$ & Silty clay and silt & 44.17 & $x x x$ & $x x x$ & $x x x x x$ & $\mathrm{xx}$ & $\mathrm{xx}$ & $\mathrm{x}$ & $\mathrm{x}$ & $\mathrm{x}$ & $\mathrm{x}$ & & & $\mathrm{xxx}$ & & & & & & & $\mathrm{x}$ & & & & \\
\hline $8 \mathrm{H}-2,3 \mathrm{I}-33$ & Silt to silty clay & 60.64 & $x x x x$ & $\mathrm{xx}$ & $x x x x x$ & $\mathrm{x}$ & $x x x$ & $\mathrm{x}$ & $\mathrm{x}$ & $\mathrm{x}$ & $\mathrm{x}$ & & & $\mathrm{xxx}$ & & & & & & & $\mathrm{x}$ & & & & \\
\hline $9 \mathrm{X}-2,38-40$ & Silt to silty clay & 64.38 & $x \mathbf{x x}$ & $\mathrm{x}$ & $x x x x x$ & $x \mathbf{x x}$ & $\mathrm{xx}$ & $\mathrm{x}$ & $\mathrm{x}$ & & $\mathrm{x}$ & & & $x x x x$ & & & & & & & $\mathrm{x}$ & & & & \\
\hline $9 X-4,52-56$ & Silty clay & 67.52 & $\mathrm{xxx}$ & $x x x$ & $x x x x x$ & $x x$ & $\mathrm{x}$ & $\mathrm{x}$ & $\mathrm{x}$ & & $\mathrm{x}$ & & & $\mathrm{xxx}$ & & & & & & & $\mathrm{x}$ & & & & \\
\hline $11 X-\mathrm{CC}, 10-12$ & Sandy siltstone & 73.57 & $\mathrm{xxxx}$ & $\mathrm{xxx}$ & $x \mathrm{xxxx}$ & $\mathrm{xx}$ & $x$ & $\mathrm{xx}$ & $\mathrm{x}$ & & $\mathrm{x}$ & & & $\mathrm{xxx}$ & & & & & & & $\mathrm{x}$ & & & & \\
\hline $12 \mathrm{X}-\mathrm{CC}, 11-13$ & & 81.91 & $\mathrm{x}$ & & $\mathrm{xxx}$ & $\mathrm{x}$ & & & & $\mathrm{xx}$ & $\mathrm{x}$ & & & $x x x x x$ & & & & & & & $\mathrm{x}$ & & & & \\
\hline $15 \times-1,35-37$ & Sandstone & 110.95 & $x x x x$ & $x x x$ & $x x x x x$ & $\mathrm{x}$ & $x x$ & $\mathrm{x}$ & & & $\mathrm{x}$ & & & $x x x$ & & & $x$ & & & $x$ & $\mathrm{x}$ & $x$ & & & \\
\hline $16 \times-1,38-40$ & Claystone & 120.68 & $x \mathrm{xx}$ & $\mathrm{xx}$ & $x x x x x$ & & ? & & & & $\mathrm{x}$ & & & $\mathrm{x}$ & & & & & & $x x$ & & & & & \\
\hline $18 \mathrm{X}-1,116-118$ & Silty claystone & 140.76 & $x x x$ & $x x$ & $x x x x x$ & $x x$ & $x$ & & & & $x$ & & & & & & & & & $\mathrm{xx}$ & $\mathrm{x}$ & & & & \\
\hline $18 \mathrm{X}-2,109-111$ & Silty claystone & 142.19 & $\mathrm{xxx}$ & $\mathrm{xx}$ & $x x x x x$ & $\mathrm{xxx}$ & $\mathrm{xx}$ & & & & $\mathrm{x}$ & & & $x x$ & & & & & & $\mathrm{xx}$ & $x$ & & & & \\
\hline $18 \mathrm{X}-3,14-16$ & Silty claystone & 142.74 & $x x x$ & $\mathrm{xx}$ & $x x x x x$ & $x \mathbf{x x}$ & $\mathrm{xx}$ & & $\mathrm{x}$ & & $\mathrm{x}$ & & & $\mathrm{xx}$ & & & & & & $\mathrm{xx}$ & $\mathrm{x}$ & & & & \\
\hline $19 X-1,28-30$ & Silty claystone & 149.58 & $x x x$ & $\mathrm{x}$ & $x x x x x$ & $x x x$ & ? & & & & & & & & & & & & & $x$ & & & & & \\
\hline $20 \times-1.62-64$ & Silty claystone & 159.62 & $x x x$ & $?$ & $x \mathrm{xxxx}$ & $x x x$ & ? & & & & & & & & & & & & & & $\mathrm{x}$ & & & & \\
\hline $20 \mathrm{X}-3,39-41$ & Sandstone & 162.32 & $x x x x$ & $x x x$ & $x x x x$ & $x x$ & $x x x$ & & & & $\mathrm{x}$ & & & & & & & & & $x x x$ & $\mathrm{x}$ & & & & \\
\hline $20 \times-4,100-103$ & Silty claystone & 164.44 & $x x x$ & $x x x$ & $x x x x x$ & $x x x$ & $\mathrm{xx}$ & & $\mathrm{x}$ & & $\mathrm{x}$ & & & & & & & & & $\mathrm{xx}$ & $x$ & & & & \\
\hline $21 X-1,117-120$ & Silty claystone & 169.77 & $x x x$ & $\mathrm{xx}$ & $x x x x x$ & $x x x$ & $\mathrm{xx}$ & & $\mathrm{x}$ & & $\mathrm{x}$ & & & & & & & & & $\mathrm{x}$ & $\mathrm{x}$ & & & & \\
\hline $21 X-2,31-34$ & Silty claystone & 170.41 & $x x x x$ & $x x x$ & $x x x x x$ & $x x x$ & $\mathrm{xx}$ & & & & $\mathrm{x}$ & & & & & & $x$ & & & $\mathrm{x}$ & $\mathrm{x}$ & & & & \\
\hline $21 X-3,57-59$ & Siltstone & 171.98 & $\mathrm{xxxx}$ & $x$ & $x x x x$ & $\mathrm{xxx}$ & $x x$ & & & & $\mathrm{x}$ & & & & & & $\mathrm{x}$ & & & $x x$ & $\mathrm{x}$ & & & & \\
\hline $24 \mathrm{X}-1,33-35$ & Siltstone & 197.93 & $x x$ & $\hat{\mathrm{xx}}$ & $\begin{array}{l}x \times x x x \\
x x y x\end{array}$ & $x x$ & $?$ & & $\mathrm{x}$ & & $n$ & & & & & & $n^{n}$ & & & $\mathrm{xx}$ & $\hat{\mathrm{x}}$ & & & & \\
\hline $24 \mathrm{X}-1,72-74$ & Silty claystone & 198.32 & $x x x$ & $x x x$ & $\begin{array}{l}\min \\
x \times x x x\end{array}$ & $x x x$ & $\mathrm{xx}$ & & $\hat{\mathrm{x}}$ & & $\mathrm{x}$ & & & & & & & & & $\mathrm{xx}$ & $\hat{n}$ & & & & \\
\hline $25 \times-1,29-32$ & Siltstone & 207.59 & $x x$ & $\mathrm{xx}$ & $\begin{array}{l}\ln x x x x x \\
x x x y\end{array}$ & $\mathrm{xxx}$ & $\mathrm{xx}$ & & & & $\hat{x}$ & & & $\mathrm{xxx}$ & & & & & & & $\mathrm{x}$ & & & & \\
\hline $27 \mathrm{X}-1.33-35$ & Siltstone & 226.93 & $\mathrm{xxxx}$ & $x x x$ & $x x x x$ & $x x x$ & $\mathrm{xx}$ & & & & $\mathrm{x}$ & & & $\mathrm{xxx}$ & & & & & & & $\mathrm{x}$ & & & & \\
\hline $28 \mathrm{X}-\mathrm{CC}, 4-5$ & Siltstone & 236.24 & $x x x$ & $x x x$ & $x \times x$ & $\mathrm{xx}$ & $\mathrm{xx}$ & & & & $n$ & & & $x \times x$ & & & & & & $v$ & $\hat{\mathrm{x}}$ & & & & \\
\hline $29 \times-1,30-32$ & Sandstone & 246.20 & $x \times x$ & $x x x$ & $\begin{array}{l}12 n x \\
x x x x\end{array}$ & $n \mathrm{~m}$ & $\mathrm{xx}$ & & & & & & & 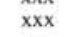 & & & & & & $y-x$ & $\hat{\mathrm{x}}$ & & & & \\
\hline $30 \mathrm{X}-1,67-70$ & Silty claystone & 256.27 & $\mathrm{xxxx}$ & $x x x$ & $x \times x x x$ & $\mathrm{xxx}$ & $\mathrm{xx}$ & & & & $\mathrm{x}$ & & & $\mathrm{xx}$ & & & & & & & $\hat{\mathrm{x}}$ & & & & \\
\hline $31 \mathrm{X}-1,65-67$ & Silty claystone & 265.95 & $\mathrm{xxxx}$ & $\mathrm{xx}$ & $x \times x \times x$ & $x \times x$ & $\mathrm{xx}$ & & & & $\hat{x}$ & & & $x x x$ & & & & & & & $\mathrm{x}$ & & & & \\
\hline 139-858B- & & & & & & & & & & & & & & & & & & & & & & & & & \\
\hline IH-2, 50-54 & Silty clay & 2.00 & $\mathrm{xxx}$ & $\mathrm{xx}$ & $x x x x x$ & $\mathrm{xxx}$ & $x x$ & & & $x x x$ & $x \mathrm{xx}$ & & & $\mathrm{xxx}$ & & & & & & & & & & & \\
\hline $2 \mathrm{H}-3,50-52$ & Sand & 10.70 & & & & & & & & & & & $x x x$ & $\mathrm{xxxx}$ & & & & & & & $x x x x$ & $\mathrm{x}$ & $\mathrm{x}$ & $x x$ & $x x x$ \\
\hline $2 \mathrm{H}-5,16-18$ & Silt to silty clay & 13.36 & $\mathrm{xxx}$ & $x x x$ & $x x x x x$ & $x x x$ & $x x$ & $\mathrm{x}$ & & & $\mathrm{x}$ & & & & & & $\mathrm{x}$ & & $\mathrm{x}$ & $\mathrm{x}$ & $x$ & & & & \\
\hline $2 \mathrm{H}-6,69-71$ & Silty clay & 15.39 & $\mathrm{xxx}$ & $x x x$ & $x x x x x$ & $\mathrm{xxx}$ & $x x$ & $\mathrm{x}$ & & & & & & & & & $\mathrm{x}$ & & $\mathrm{x}$ & & $x$ & & & & \\
\hline $139-858 \mathrm{C}$ - & & & & & & & & & & & & & & & & & & & & & & & & & \\
\hline $2 \mathrm{H}-5,32-34$ & Silty clay & 9.82 & & & $x x x$ & & & & & $\mathrm{xx}$ & $\mathrm{x}$ & & & $x x x x x$ & & & & & & & & & & & \\
\hline $2 \mathrm{H}-7,15-17$ & Silty clay & 12.65 & $\mathrm{xxx}$ & $x x x$ & $x x x x x$ & $x x x$ & ? & $x$ & & $\mathrm{xx}$ & & & & $\mathrm{xxxx}$ & & & & & $\mathrm{x}$ & & $\mathrm{xx}$ & $\mathrm{x}$ & $\mathrm{x}$ & & \\
\hline $3 \mathrm{H}-1,78-81$ & Siltstone & 13.78 & $x x$ & $\mathrm{x}$ & & & $x x$ & & & & $x x x$ & & & $x x x x x$ & & & & & & & & & & & \\
\hline $3 \mathrm{H}-2,10-15$ & Silty clay & 14.60 & $x x$ & $\mathrm{x}$ & & & $x$ & & & & $\mathrm{xx}$ & & & $x x x x x$ & & & & & & & $\mathrm{xx}$ & & & & \\
\hline $3 \mathrm{H}-2,54-57$ & Silt to sand & 15.04 & & & $x x x$ & & & & & & $\mathrm{x}$ & & & $x x x x x$ & & & & & & & $\mathrm{x}$ & & & & \\
\hline $3 \mathrm{H}-2,110-115$ & Silt to sand & 15.60 & & & $x x x x$ & $\mathrm{x}$ & $x \mathbf{x x}$ & & & & & & & $x x x x x$ & & & & & & & $x$ & & & & \\
\hline $3 \mathrm{H}-2,124-126$ & Silt to sand & 15.74 & & & $x x x$ & $\mathrm{x}$ & $x x$ & & & & & & & $x x x x x$ & & & & & & & $x$ & & & & \\
\hline $3 \mathrm{H}-3,38-41$ & Silt to silty clay & 16.38 & & & & & & & & $x x$ & $x$ & & & $x x x x x$ & & & & & & & $x x x$ & & & & \\
\hline $3 \mathrm{H}-3,107-109$ & Silt & 17.07 & $x \mathrm{xxx}$ & $\mathrm{xxx}$ & $x x x x x$ & $x x$ & & & & & & & & $x x x$ & & & & & & & $x x x$ & & & & \\
\hline $3 \mathrm{H}-6,86-89$ & Silt & 21.36 & $x x x x$ & $x x x$ & $x x x x x$ & $x x x$ & $x$ & $x$ & & & & & & $x$ & $x x$ & & & & & & $x x$ & $\mathrm{xx}$ & $x$ & & \\
\hline $5 \mathrm{H}-1,122-124$ & Silty clay & 24.72 & $x x x$ & $x x x$ & $x x x x x$ & $\mathrm{xxx}$ & $?$ & $x x$ & & & & & & $x x x x$ & & & & & & & $x$ & & & & \\
\hline $5 \mathrm{H}-3,5-7$ & Silty clay & 26.55 & $\mathbf{x x x x}$ & $x x x x$ & $x x x x$ & $\mathrm{xxx}$ & $x$ & $x x$ & & & & & & $v-x x$ & & & & & & & $\mathrm{xx}$ & & & & \\
\hline $5 \mathrm{H}-3,61-63$ & Silty clay & 27.11 & $x \mathbf{x x x}$ & $x$ & $x x x x x$ & $x x x x$ & $x$ & $x x$ & & & $\mathrm{x}$ & & & $x x x$ & & & & & & & $x$ & & & & \\
\hline 5H-CC, 7-10 & Silt & 33.20 & $\mathrm{xxxxx}$ & $x x$ & $\mathrm{xxx}$ & $\mathrm{xxx}$ & $x x$ & $\mathrm{xx}$ & & & & & & $\mathrm{xx}$ & & & & & & & $\mathrm{x}$ & & & & \\
\hline $6 \mathrm{H}-1,80-82$ & Sandy-siltstone & $\begin{array}{l}33.80 \\
355\end{array}$ & $x x x x x$ & $\mathrm{xx}$ & $x x x x$ & $\mathrm{xxx}$ & $x_{0}$ & $x x$ & & & & & & & & & & & & & $x$ & & $\mathrm{x}$ & & \\
\hline $\begin{array}{l}6 \mathrm{H}-2,75-77 \\
6 \mathrm{H}-4,43\end{array}$ & $\begin{array}{l}\text { Silty clay } \\
\text { Siltyclav }\end{array}$ & $\begin{array}{l}35.25 \\
33.93\end{array}$ & $x x x x$ & $\mathrm{xxx}$ & $x_{x x x x}^{x x y x}$ & $x$ & $?$ & $\mathrm{x}$ & & & & & & $x x x x x$ & & & & & & $\mathrm{x}$ & $x^{x}$ & & $x$ & & $x$ \\
\hline $01 n^{-4}, 43-51$ & & & & & & & & & & & & & & & & & & & & & & & $x^{x}$ & & $x$ \\
\hline
\end{tabular}


Table 12 (continued).

\begin{tabular}{|c|c|c|c|c|c|c|c|c|c|c|c|c|c|c|c|c|c|c|c|c|c|c|c|c|c|}
\hline \multirow{2}{*}{$\begin{array}{l}\text { Core, section, } \\
\text { Interval }(\mathrm{cm})\end{array}$} & \multirow{2}{*}{$\begin{array}{l}\text { Grain } \\
\text { size }\end{array}$} & \multirow{2}{*}{$\begin{array}{l}\text { Depth } \\
\text { (mbsf) }\end{array}$} & \multicolumn{9}{|c|}{ Detrital } & \multicolumn{14}{|c|}{ Hydrothermal/Authigenic } \\
\hline & & & Qz & Fs & Clay & Micas & $\mathrm{Ch}$ & Ep & Mag & M-F & F-py & $Q_{z}$ & $\mathrm{Ta}$ & Carb & Wa & Ep & $\mathrm{Ru}$ & Sn & $\mathrm{Ba}$ & $\mathrm{An}$ & Py & $\mathrm{Mr}$ & Po & $\mathrm{Cp}_{\mathrm{p}}$ & Sp \\
\hline $6 \mathrm{H}-5,76-79$ & Silty claystone & 39.76 & $x x x x$ & $x x x$ & $x x x x x$ & $x x x$ & $\mathrm{xx}$ & $\mathrm{x}$ & & & & & & & & & & & & & $\mathrm{x}$ & & $\mathrm{x}$ & & \\
\hline $7 \mathrm{H}-1,90-92$ & Silty clay + sandy silt & 42.40 & $x x x$ & $x x x$ & $x x x x x$ & $x x x$ & $\mathrm{xx}$ & & & & & & & & & $x$ & & & & & $x$ & & & & \\
\hline $11 X-1,33-35$ & Clayey siltstone & 54.83 & $x x x x$ & $\mathrm{xxx}$ & $x x x x x$ & $\mathrm{xx}$ & $\mathrm{x}$ & & & & $\mathrm{x}$ & & & & & & & & & & $\mathrm{x}$ & & & & \\
\hline $12 \times-1,42-45$ & Siltstone & 64.20 & $x x x x$ & $x x x$ & $x x x x x$ & $\mathrm{x}$ & $\mathrm{xx}$ & $\mathrm{x}$ & & & & & & & & & & & & & $\mathrm{x}$ & & & & \\
\hline $12 \mathrm{X}-\mathrm{CC}, 8-10$ & Sand to silt & 68.14 & $\mathrm{xxxx}$ & $\mathrm{xxx}$ & $x x x x x$ & $x x$ & $\mathrm{xx}$ & $x x$ & & & & & & & & & & & & $\mathrm{xx}$ & $\mathrm{x}$ & & & & \\
\hline $13 \mathrm{X}-1,25-28$ & Silty clay & 73.95 & $x x x x$ & $x x$ & $x x x x x$ & $\mathrm{x}$ & $x x$ & $\mathrm{x}$ & & & & & & & & & & & & & $\mathrm{x}$ & & $x$ & & \\
\hline \multicolumn{26}{|l|}{$139-858 \mathrm{D}-$} \\
\hline $1 \mathrm{H}-1,115-119$ & Silty clay & 1.15 & $x x x$ & $x x x$ & $x x x x x$ & $\mathrm{xxx}$ & $\mathrm{xx}$ & $\mathrm{x}$ & & $\mathrm{xxx}$ & $x$ & & & $\mathrm{xx}$ & & & & & & & $x x x$ & & & & \\
\hline $2 \mathrm{H}-3,34-36$ & Silty clay & 12.64 & $x x x$ & $x x x$ & $x x x x x$ & $\mathrm{xx}$ & $x x$ & & & & $x$ & & & $\mathrm{x}$ & & & & & & & $x x$ & & $x$ & & \\
\hline $2 \mathrm{H}-\mathrm{CC}, 10-12$ & Silty clay & 18.92 & $\mathrm{xxx}$ & $\mathrm{xx}$ & $x x x x x$ & $\mathrm{xxx}$ & $\mathrm{xx}$ & & & & & & & & & & & & & & $x \mathrm{x}$ & $\mathrm{xx}$ & & & $\mathrm{x}$ \\
\hline \multicolumn{26}{|l|}{$139-858 \mathrm{~F}-$} \\
\hline $2 \mathrm{R}-\mathrm{CC}, 7-10$ & Siltstone & 27.87 & $x x x$ & $x x x$ & $x x x x x$ & $x$ & $?$ & & & & & $\mathrm{v}$ & & & $v$ & & & & & & $v-x$ & & & & \\
\hline $4 \mathrm{R}-\mathrm{CC}, 8-10$ & siltstone to sandstone & 46.58 & $x x x x x$ & $\mathbf{x x x}$ & $x x x x$ & $\mathrm{x}$ & $\mathrm{xx}$ & & & & & & & & & $x x$ & & & & & & & & & \\
\hline 9R-CC, 9-11 & Sandstone & 94.29 & & $x x x x^{a}$ & $x x x$ & $\mathrm{x}$ & $\mathrm{xxx}$ & & & & & $x x x x$ & & & $x x x x$ & $\mathrm{xx}$ & & $\mathrm{xx}$ & & & $\mathrm{x}$ & & & & \\
\hline $14 \mathrm{R}-1,10-12$ & Siltstone & 142.70 & $x x x x$ & $\mathrm{xxxx}$ & $x x x x$ & $\mathrm{xx}$ & $\mathrm{xx}$ & & & & & & & & & $\mathrm{xx}$ & & & & & $\mathrm{xx}$ & & & & \\
\hline $18 R-1,14-16$ & Siltstone & 181.44 & $x x x x$ & $x x x$ & $x x x x x$ & $x$ & $x x$ & & & & & & & & $v$ & $x$ & & & & & & & & & \\
\hline 23R-CC, 3-5 & Sandstone & 229.63 & $x x x x x$ & ? & $x x x x$ & & $\mathrm{xx}$ & & & & $\mathrm{x}$ & & & & & $x x x x$ & & & & & $x$ & & & & \\
\hline $25 \mathrm{R}-1,9-11$ & Claystone & 248.99 & $x x x$ & $\mathrm{x}$ & $x x x x x$ & $\mathrm{x}$ & $\mathrm{xx}$ & & & & & & & & & $x x$ & & & & & $\mathrm{x}$ & & & & \\
\hline $25 \mathrm{R}-1,71-73$ & Claystone & 249.61 & $x x x$ & $\mathrm{x}$ & $x x x x x$ & $\mathrm{xx}$ & $x x$ & & $\mathrm{x}$ & & $\mathrm{x}$ & & & & & $x x x x$ & & $x x x$ & & & $x x$ & & & & \\
\hline
\end{tabular}

Notes: $x x x x=$ dominant $(>50 \%) ; x x x=$ major $(11-50 \%) ; x x x=\operatorname{minor}(3-10 \%) ; x x=$ trace $(1-2 \%) ; x=$ rare $(\%) ; v=$ vein. $Q z=$ quartz; Fs $=$ feldspar; Ch $=$ chlorite; Carb $=$ carbonate; An $=$ anhydrite; Wa $=$ wairakite; Ep $=$ epidote; Mag $=$ magnetite; $\mathrm{M}-\mathrm{f}=$ microfossils; $\mathrm{F}$-py $=$ framboidal pyrite; $\mathrm{Ba}=$ barite $\mathrm{Py}=$ pyrite; $\mathrm{Mr}=$ marcasite; $\mathrm{Po}=$ pynthotite; $\mathrm{Cp}=$ chalcopyrite; $\mathrm{Sp}=$ sphalerite; $\mathrm{Ru}=$ rutile; $\mathrm{Sn}=$ sphene.

$\mathrm{M}-\mathrm{f}=$ microfossils; $\mathrm{F}$-py $=$ framboidal
a Probably authigenic plagioclase; see text.

Table 13. Electron microprobe data for wairakite in veins and hydrothermally altered turbiditic sediment, Holes 857D and 858F.

\begin{tabular}{|c|c|c|c|c|c|c|c|c|c|c|c|c|c|c|c|c|c|c|c|}
\hline $\begin{array}{l}\text { Site: } \\
\text { Core, section: } \\
\text { Interval }(\mathrm{cm}) \text { : } \\
\text { Zone: }\end{array}$ & & $\begin{array}{r}85 \\
6 \mathrm{~F} \\
20 \\
1\end{array}$ & & & & $\begin{array}{l}857 \mathrm{D} \\
14 \mathrm{R}-1 \\
22-25 \\
\text { Ic }\end{array}$ & & & $\begin{array}{l}\text { 857D } \\
17 \mathrm{R}-2 \\
53-55 \\
\mathrm{Ic}\end{array}$ & & & $\begin{array}{c}858 \mathrm{~F} \\
2 \mathrm{R}-\mathrm{CC} \\
8-11 \\
\mathrm{Ib}\end{array}$ & & & $\begin{array}{l}858 \mathrm{~F} \\
9 \mathrm{R}-\mathrm{CC} \\
9-11 \\
\mathrm{Ib}\end{array}$ & & & $\begin{array}{l}858 \mathrm{~F} \\
18 R-1 \\
14-16 \\
\mathrm{lb}\end{array}$ & \\
\hline $\mathrm{SiO}_{2}$ & 54.423 & 55.221 & 53.514 & 54.060 & 53.142 & 54.650 & 54.772 & 52.695 & 53.596 & 52.877 & 55.209 & 54.950 & 55.076 & 55.690 & 55.795 & 55.737 & 55.660 & 55.234 & 54.250 \\
\hline $\mathrm{Al}_{2} \mathrm{O}_{3}$ & 22.679 & 23.450 & 22.994 & 22.945 & 22.497 & 22.524 & 22.921 & 21.683 & 21.906 & 22.099 & 22.358 & 22.118 & 22.577 & 22.103 & 22.450 & 22.951 & 22.582 & 21.664 & 22.116 \\
\hline $\mathrm{FeO}$ & 0.028 & 0.004 & 0.000 & 0.005 & 0.076 & 0.090 & 0.072 & 0.000 & 0.010 & 0.000 & 0.027 & 0.030 & 0.023 & 0.014 & 0.032 & 0.001 & 0.076 & 0.109 & 0.000 \\
\hline $\mathrm{CaO}$ & 12.670 & 12.822 & 12.455 & 12.637 & 11.685 & 12.143 & 12.135 & 11.668 & 12.034 & 11.945 & 11.803 & 11.974 & 12.415 & 11.865 & 12.269 & 11.952 & 11.750 & 11.177 & 11.101 \\
\hline $\mathrm{Na}_{2} \mathrm{O}$ & 0.027 & 0.032 & 0.050 & 0.065 & 0.395 & 0.418 & 0.373 & 0.344 & 0.352 & 0.272 & 0.555 & 0.566 & 0.231 & 0.523 & 0.495 & 0.538 & 0.774 & 0.917 & 0.821 \\
\hline $\mathrm{K}_{2} \mathrm{O}$ & 0.014 & 0.018 & 0.000 & 0.017 & 0.012 & 0.014 & 0.011 & 0.011 & 0.016 & 0.006 & 0.011 & 0.008 & 0.002 & 0.012 & 0.027 & 0.030 & 0.034 & 0.023 & 0.011 \\
\hline Total & 89.841 & 91.547 & 89.013 & 89.729 & 87.807 & 89.839 & 90.284 & 86.401 & 87.914 & 87.199 & 89.963 & 89.646 & 90.324 & 90.207 & 91.068 & 91.209 & 90.876 & 89.124 & 88.299 \\
\hline $\mathrm{Ca} / \mathrm{Ca}+\mathrm{Na}$ & 0.996 & 0.996 & 0.993 & 0.991 & 0.942 & 0.941 & 0.947 & 0.949 & 0.950 & 0.960 & 0.922 & 0.921 & 0.967 & 0.926 & 0.932 & 0.925 & 0.893 & 0.871 & 0.882 \\
\hline $\mathrm{Si}$ & 32.134 & 31.994 & 31.892 & 31.973 & 32.077 & 32.259 & 32.158 & 32.308 & 32.322 & 32.148 & 32.482 & 32,478 & 32.314 & 32.657 & 32,470 & 32.349 & 32.447 & 32.782 & 32.488 \\
\hline Al & 15.787 & 16.017 & 16.155 & 15.999 & 16.009 & 15.675 & 15.865 & 15.673 & 15.575 & 15.840 & 15.508 & 15.412 & 15.616 & 15.281 & 15.403 & 15.704 & 15.520 & 15.158 & 15.614 \\
\hline $\mathrm{Fe}$ & 0.014 & 0.002 & 0.000 & 0.002 & 0.038 & 0.044 & 0.035 & 0.000 & 0.005 & 0.000 & 0.013 & 0.015 & 0.011 & 0.007 & 0.016 & 0.000 & 0.037 & 0.054 & 0.000 \\
\hline $\mathrm{Ca}$ & 8.016 & 7.960 & 7.953 & 8.009 & 7.558 & 7.680 & 7.634 & 7.665 & 7.776 & 7.782 & 7.441 & 7.583 & 7.805 & 7.455 & 7.651 & 7.433 & 7.339 & 7.108 & 7.123 \\
\hline $\mathrm{Na}$ & 0.031 & 0.036 & 0.058 & 0.075 & 0.462 & 0.478 & 0.425 & 0.409 & 0.412 & 0.321 & 0.633 & 0.649 & 0.263 & 0.595 & 0.559 & 0.605 & 0.875 & 1.055 & 0.953 \\
\hline $\mathrm{K}$ & 0.011 & 0.013 & 0.000 & 0.013 & 0.009 & 0.011 & 0.008 & 0.009 & 0.012 & 0.005 & 0.008 & 0.006 & 0.001 & 0.009 & 0.020 & 0.022 & 0.025 & 0.017 & 0.008 \\
\hline
\end{tabular}

Note: Formula proportions based on 96 (O). 
Table 14. Summary of downhole mineralogy for Holes 857A, 857C, and 857D.

\begin{tabular}{|c|c|c|c|c|c|c|c|c|c|c|c|c|c|c|c|c|c|c|c|c|c|}
\hline \multirow{2}{*}{$\begin{array}{l}\text { Core, section, } \\
\text { interval }(\mathrm{cm})\end{array}$} & \multirow{2}{*}{$\begin{array}{l}\text { Grain } \\
\text { size }\end{array}$} & \multirow{2}{*}{$\begin{array}{l}\text { Depth } \\
\text { (mbsf) }\end{array}$} & \multicolumn{10}{|c|}{ Detrital } & \multicolumn{9}{|c|}{ Hydrothermal/Authigenic } \\
\hline & & & $\mathrm{Qz}$ & Fs & Clay & Micas & $\mathrm{Ch}$ & $\mathrm{Hb}$ & Ep & Mag & M-f & F-py & $\mathrm{Qz}$ & Ch-II & Carb & Wa & Ep & Sn & Py & Po & Cp \\
\hline \multicolumn{22}{|l|}{$139-857 \mathrm{~A}-$} \\
\hline $1 \mathrm{H}-4,46-50$ & Silty clay & 6.86 & $\mathrm{xxxx}$ & $\mathrm{xxx}$ & $x x x x x$ & $\mathrm{xx}$ & $\mathrm{xx}$ & $\mathrm{xx}$ & $\mathrm{x}$ & $\mathrm{x}$ & & $\mathrm{x}$ & & & & & & & $\mathrm{x}$ & & \\
\hline $2 \mathrm{H}-3,125-127$ & Silty clay & 15.65 & $x x x$ & $x x x$ & $x x x x x$ & $\mathrm{xx}$ & $\mathrm{xx}$ & $\mathrm{xx}$ & & 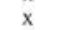 & $\mathrm{xxx}$ & $x x x$ & & & $x x x x$ & & & & $\mathrm{x}$ & & \\
\hline $4 \mathrm{H}-4,25-29$ & Silty clay & 26.65 & $x \mathbf{x x}$ & $x x x$ & $x \times x x x$ & $x x x$ & $\mathrm{xx}$ & $\mathrm{xx}$ & $\mathrm{x}$ & $\hat{x}$ & $x$ & $x$ & & & $x x$ & & & & & & \\
\hline $6 \mathrm{H}-5,89-93$ & Silt & 47.79 & $x x x x$ & $\mathrm{xxxx}$ & $x \times x x$ & $x \times x$ & $\mathrm{xx}$ & $x \times x$ & $\hat{\mathrm{xx}}$ & $\hat{x}$ & $\hat{x}$ & $\hat{x}$ & & & $\mathrm{xxx}$ & & & & $x$ & & $\mathrm{x}$ \\
\hline $7 \mathrm{H}-6,109-113$ & Silty clay & 56.77 & $x x x x$ & $\mathrm{xxx}$ & $x \times x \times x$ & $x x$ & $x x x$ & $x x$ & $x$ & $x$ & $\mathrm{x}$ & $x$ & & & $x x$ & & & & $\hat{x}$ & & \\
\hline $8 \mathrm{H}-7,3-7$ & Silty clay & 68.93 & $x x x x$ & $x \times x$ & $x x x x x$ & $\mathrm{xx}$ & $\mathrm{xx}$ & $\mathrm{x}$ & $\hat{x}$ & $\hat{x}$ & $\hat{x}$ & $\hat{x}$ & & & $x^{2 x}$ & & & & $\hat{x}$ & & \\
\hline $9 \mathrm{H}-7,53-55$ & Clayey silt & & $\begin{array}{l}1 \\
x x x x\end{array}$ & $x \mathrm{xxx}$ & $x$ & $x x$ & $\mathrm{xxx}$ & $\hat{\mathrm{xx}}$ & $\hat{x}$ & $\hat{x}$ & & & & & $\hat{x}$ & & & & $\hat{x}$ & & \\
\hline $10 \mathrm{H}-4,77-79$ & Silty sand & 84.17 & $\begin{array}{l}2 x i n \\
x \times x x\end{array}$ & $\begin{array}{l}x \times x \\
x x x x\end{array}$ & $\begin{array}{l}\sin x \times x \\
x \times x\end{array}$ & $\mathrm{x}$ & $\mathrm{xx}$ & $\mathrm{x}$ & $\hat{x}$ & $\hat{x}$ & $\mathrm{x}$ & & & & $\hat{x x}$ & & & & $\mathrm{x}$ & & \\
\hline 1IX-CC, $26-28$ & Silty clay & 87.33 & $\mathrm{xxx}$ & $\mathrm{xx}$ & $x x x x x$ & $\mathrm{x}$ & $x x$ & & & $\mathrm{x}$ & & $\mathrm{x}$ & & & $x x x x x$ & & & & & & \\
\hline $13 \mathrm{X}-1,25-27$ & Silty clay & 101.75 & $\mathrm{xxxx}$ & $\mathrm{xxx}$ & $\mathrm{xxxxx}$ & $\mathrm{x}$ & $\mathrm{xx}$ & & & $\mathrm{x}$ & & $\mathrm{x}$ & & & & & & & & & \\
\hline $13 \times-1,91-93$ & Silty clay & 102.41 & $x x x x$ & $\mathrm{xxx}$ & $x \mathrm{xxxx}$ & $\mathrm{x}$ & $x x$ & $\mathrm{x}$ & & $\mathrm{x}$ & & $\mathrm{x}$ & & & $x x x$ & & & & $\mathrm{x}$ & $\mathrm{x}$ & \\
\hline \multicolumn{22}{|l|}{$139-857 \mathrm{C}$. } \\
\hline $3 \mathrm{R}-3,110-112$ & Silty clay & 70.60 & $\mathrm{xxxx}$ & $x x x$ & $x x x x x$ & $x x x$ & $\mathrm{xxx}$ & & $\mathrm{x}$ & $\mathrm{x}$ & $\mathrm{xx}$ & $\mathrm{x}$ & & & $\mathrm{x}$ & & & & $\mathrm{x}$ & & \\
\hline $6 \mathrm{R}-1,1-2$ & Silty claystone & 86.21 & $\mathrm{xxx}$ & $\mathrm{xx}$ & & $\mathrm{x}$ & $\mathrm{x}$ & & & $\mathrm{x}$ & & $x$ & & & $x x x x x$ & & & & & & \\
\hline $7 \mathrm{R}-\mathrm{CC}, 1-2$ & Clayey silt & 95.21 & $\mathrm{xxx}$ & $\mathrm{xxx}$ & & $\mathrm{x}$ & $\mathrm{xx}$ & $\mathrm{x}$ & $x$ & $\mathrm{x}$ & & $\mathrm{xx}$ & & & $x x x x x$ & & & & & & \\
\hline $9 R-1,8-9$ & Siltstone & 114.58 & $\mathrm{xxx}$ & $\mathrm{x}$ & & & $\mathrm{xx}$ & & $\hat{\mathrm{x}}$ & $\hat{\mathrm{x}}$ & & $\mathrm{x}$ & & & $x x x x x$ & & & & & & \\
\hline $13 \mathrm{R}-1,6-8$ & Siltstone & 153.16 & 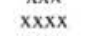 & $x \times x x$ & $\mathrm{xxxx}$ & $\mathrm{x}$ & $x x x$ & & $\hat{x}$ & $\hat{x}$ & & $\hat{x}$ & & & $x \times x$ & & & & & & \\
\hline $13 R-3,52-54$ & Clayey silt & 156.62 & $\mathrm{xxxx}$ & $\mathrm{xxxx}$ & $x x x x$ & $\mathrm{x}$ & $\mathrm{xx}$ & & $\mathrm{xx}$ & $\mathrm{x}$ & & $\mathrm{x}$ & & & $\mathrm{xxx}$ & & & & $\mathrm{x}$ & & \\
\hline $15 \mathrm{R}-1,147-149$ & Silty clay & 173.97 & $x x x x$ & $x x x x$ & $x \times x \times x$ & $\hat{x x}$ & $x x$ & & $\hat{x}$ & $\hat{x}$ & & $\hat{x}$ & & & $x \times x x$ & & & & $\hat{x}$ & & \\
\hline $17 R-2,61-65$ & Sandy/silty clay & 194.01 & $x \times x$ & $x x x$ & $x x x \times x$ & $\hat{x x}$ & $x$ & & $\hat{x}$ & $\hat{x}$ & & $\hat{x}$ & & & $x x$ & & & & $\hat{x}$ & & \\
\hline $21 \mathrm{R}-1,24-026$ & Silty claystone & 230.84 & $\frac{1}{x \times x x}$ & $\begin{array}{l}\operatorname{xin} \\
\operatorname{xxxx}\end{array}$ & $x \times x$ & $\begin{array}{l}1 \mathrm{x} \\
\mathrm{xxx}\end{array}$ & $\hat{x x}$ & & $\hat{x x}$ & $\hat{x}$ & & $\hat{x}$ & & & $x x$ & & & & $\hat{x}$ & $x$ & \\
\hline $21 \mathrm{R}-3,27-29$ & Silty claystone + siltstone & 233.87 & $x x x x$ & $x x x x$ & $x \times x \times x$ & $\mathrm{xxx}$ & $\mathrm{x}$ & & & $\hat{x}$ & & $\hat{x}$ & & & & & & & & & \\
\hline $22 \mathrm{R}-1,28-32$ & Silty claystone & 240.58 & $\begin{array}{l}2 x x x \\
x x x x\end{array}$ & $x x x$ & $\begin{array}{l}1 \\
x x x x x \\
x x y x\end{array}$ & $\begin{array}{l}2 x_{x} \\
x x x\end{array}$ & $\hat{x}$ & & & $\hat{x}$ & & $\hat{x}$ & & & $\mathrm{x}$ & & & & & & \\
\hline $22 \mathrm{R}-\mathrm{CC}, 1-5$ & Silty claystone & 242.01 & $x \times x$ & $\mathrm{xx}$ & $\begin{array}{l}\ln x \times x \\
x \times x x\end{array}$ & $\begin{array}{l}2 \mathrm{xx} \\
\mathrm{xxx}\end{array}$ & $\hat{x}$ & & $\mathrm{x}$ & 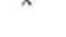 & & $\hat{x}$ & & & $\hat{x x x x}$ & & & & $\mathrm{x}$ & & \\
\hline $24 \mathrm{R}-1,31-35$ & Silty claystone & 259.51 & $\mathrm{xxxx}$ & $x x x x$ & $x x x x$ & $x x x$ & $\mathrm{x}$ & & $x x x$ & & & $\mathrm{x}$ & & & $\mathrm{xxx}$ & & & & $\mathrm{x}$ & & \\
\hline $25 \mathrm{R}-1,6-8$ & Silty claystone & 268.86 & $x x x x$ & $x x x$ & $x x x x$ & $\mathrm{xxx}$ & $\mathrm{x}$ & & $\mathrm{x}$ & & & $\mathrm{x}$ & & & $x x x$ & & & & $\mathrm{x}$ & & \\
\hline $28 \mathrm{R}-2,119-122$ & Silty claystone & 296.49 & $\mathrm{xxx}$ & $\mathrm{xxx}$ & $x x x x x$ & $\mathrm{xxx}$ & $\hat{\mathrm{x}}$ & & & & & $\hat{x}$ & & & $\mathrm{xxx}$ & & & & $\hat{x}$ & & \\
\hline 28R-CC, - & Sandy silt & & $x \times x x$ & $x \times x x$ & $x \times x$ & $x \times x$ & $\hat{x x}$ & & $\mathrm{x}$ & & & $\hat{x}$ & & & $x x x x x$ & & & & & & \\
\hline $30 \mathrm{R}-1,116-120$ & Silty clay + sandy silt & 314.26 & $\mathrm{xxxx}$ & $x x x x$ & $x x x x$ & $\mathrm{xxx}$ & $\mathrm{xx}$ & & $\mathrm{xx}$ & & & $\mathrm{x}$ & & & $\mathrm{xxx}$ & & & & & & \\
\hline $31 \mathrm{R}-1,121-123$ & Silty claystone & 323.91 & $x \times x$ & $x \times x$ & $x \times x \times x$ & $\mathrm{xxx}$ & $\mathrm{xx}$ & & $\mathrm{x}$ & & & & & & $x$ & & & & $\mathrm{x}$ & & \\
\hline $31 \mathrm{R}-2,15-17$ & Silty claystone & 324.35 & $x \times x x$ & $x \times x$ & $x x x x x$ & $x x x$ & & & $\hat{x}$ & & & $x$ & & & $\hat{x x}$ & & & & $\hat{x}$ & & \\
\hline $32 \mathrm{R}-1,34-37$ & Silty claystone to sandy siltstone & 327.94 & $x \times x x$ & $x_{x x}$ & $x \times x \times x$ & $x \times x$ & $x$ & & $\hat{x x}$ & & & $\hat{x}$ & & & & & & & $\hat{x}$ & & \\
\hline $33 \mathrm{R}-1,56-59$ & Silty claystone & 332.96 & $\mathbf{x x x x}$ & $\mathrm{xxxx}$ & $x x x x x$ & $\mathrm{xxx}$ & $\mathrm{x}$ & & $\mathrm{xxx}$ & & & $\hat{x}$ & & & $\mathrm{xxx}$ & & & & $\hat{x}$ & & \\
\hline $33 \mathrm{R}-3,65-68$ & Silty claystone & 336.05 & $x x x$ & $x x x$ & $x \times x x x$ & $\mathrm{xxx}$ & $\hat{x}$ & & $x \times x$ & & & & & & $x x$ & & & & $\hat{x x}$ & & \\
\hline $34 \mathrm{R}-1,120-122$ & Siltstone & 337.70 & $\mathrm{xxxx}$ & $\mathrm{xxx}$ & $x x x x x$ & $\mathrm{xxx}$ & $\mathrm{xx}$ & & $\mathrm{x}$ & & $\mathrm{x}$ & $x$ & & & $\mathrm{xxx}$ & & & & & & \\
\hline $34 \mathrm{R}-3,44-47$ & $\begin{array}{l}\text { Silts claystone } \\
\text { Siltion }\end{array}$ & 339.94 & $\mathrm{xxxx}$ & $\mathrm{xxxx}$ & $\mathrm{xxxx}$ & $\mathrm{xxx}$ & $\mathrm{xx}$ & & $\mathrm{x}$ & & $\mathrm{x}$ & $\mathrm{x}$ & & & $\mathrm{xx}$ & & & & & & \\
\hline $36 \mathrm{R}-3,58-61$ & Silty claystone to siltstone & 349.68 & $\mathrm{xxxx}$ & $\mathrm{xxx}$ & $x x x x x$ & $\mathrm{xx}$ & $x x$ & & $\mathrm{x}$ & & & & & & $\mathrm{xxx}$ & & & & & & \\
\hline $37 \mathrm{R}-1,115-119$ & Silty claystone to siltstone & 351.95 & $x x x x$ & $x x x x$ & $x x x x x$ & $x x x$ & $\mathrm{x}$ & & $\mathrm{x}$ & & & $x$ & & & $x x x$ & & & & $\mathrm{x}$ & & \\
\hline $38 \mathrm{R}-2,50-53$ & Silty claystone to siltstone & 357.80 & $\mathrm{xxxx}$ & $\mathrm{xxx}$ & $x \mathrm{xxxx}$ & $\mathrm{xxx}$ & $\hat{x}$ & & $\hat{\mathrm{x}}$ & & & $\hat{x}$ & & & $\mathrm{xxx}$ & & & & & & \\
\hline $39 \mathrm{R}-1,66-68$ & Silty claystone to siltstone & 361.06 & $x x x x$ & $x x x$ & $x \times x \times x$ & $\begin{array}{l}2 \times x \\
x \times x\end{array}$ & $\hat{x}$ & & & & $\mathrm{x}$ & $\hat{x}$ & & & $\begin{array}{l}n x x \\
x \times x\end{array}$ & & & & $x$ & & \\
\hline $39 R-3,62-65$ & Siltstone & 364.02 & $x x x x$ & $x x x x$ & $x x x x x$ & $x x x$ & $x x$ & & $\mathrm{x}$ & & $\mathrm{x}$ & $\hat{x}$ & & & $x x x$ & & & & $\hat{x}$ & & \\
\hline $41 \mathrm{R}-2,122-126$ & Silty claystone + sandy siltstone & 377.62 & $\begin{array}{l}\operatorname{xin} x \\
x \times x x\end{array}$ & $\begin{array}{l}\sin x \\
\mathrm{xxxx}\end{array}$ & 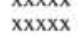 & $\begin{array}{l}x \times x \\
\mathrm{xxx}\end{array}$ & $x$ & & $x$ & & & $\mathrm{x}$ & & & $\begin{array}{l}\ln x \\
x \times x\end{array}$ & & & & $\mathrm{x}$ & & \\
\hline $42 \mathrm{R}-2,37-41$ & Siltstone & 381.57 & $\begin{array}{l}\operatorname{xixx} \\
x \times x x\end{array}$ & $\begin{array}{c}\operatorname{xixx} \\
\mathrm{xxx}\end{array}$ & 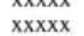 & $\begin{array}{l}x \times x \\
x \times x\end{array}$ & $\underset{x x}{x}$ & & $x$ & & & $x$ & & & $x x$ & & & & $\lambda$ & & \\
\hline $43 \mathrm{R}-3,77-81$ & Silty claystone & 388.47 & $\begin{array}{l}\operatorname{xin} x \\
x \times x x\end{array}$ & 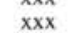 & $\begin{array}{l}\operatorname{Ansin} x \\
x \times x \times x\end{array}$ & $\begin{array}{l}2 \times x \\
x x x\end{array}$ & $x$ & & $\hat{x}$ & & & $\hat{x}$ & & & $\begin{array}{ll}1 n \\
x x\end{array}$ & & & & & & \\
\hline $44 \mathrm{R}-1,137-140$ & Siltstone to silty claystone & 391.07 & $x \mathrm{xxx}$ & $\mathrm{xxxx}$ & $x \times x$ & $\mathrm{xxx}$ & $\hat{x}$ & & $\hat{x x}$ & & & $\hat{x}$ & & & $\mathrm{xxx}$ & & & & $\mathrm{x}$ & & \\
\hline $45 \mathrm{R}-1,134-138$ & Siltstone + silty claystone & 395.64 & $\begin{array}{l}x \times x x \\
x x x x\end{array}$ & $\begin{array}{l}x+x \times x \\
x x x x\end{array}$ & $\begin{array}{l}x \times x \\
x \times x\end{array}$ & $x \times x$ & $\hat{x x}$ & & $x$ & & & $\hat{x}$ & & & 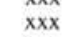 & & & & $\hat{x}$ & & \\
\hline $45 \mathrm{R}-2,79-81$ & Silty claystone & 396.59 & $x x x x$ & $x x x$ & $\mathrm{xxxx}$ & $\mathrm{xxx}$ & $\mathrm{x}$ & & $\mathrm{x}$ & & $\mathrm{x}$ & $x$ & & & $x x x$ & & & & $\mathrm{x}$ & & \\
\hline $46 \mathrm{R}-1,71-75$ & Silty claystone & 399.71 & $\begin{array}{l}x \times x \\
x x x x\end{array}$ & $\begin{array}{l}x x y \\
x x x\end{array}$ & $\begin{array}{l}x \times x x \\
x \times x x x\end{array}$ & $x \times x$ & $\hat{x}$ & & $\hat{x}$ & & & $\hat{x}$ & & & $x x x$ & & & & $\mathrm{x}$ & & \\
\hline $53 R-1,50-52$ & Silty claystone & 433.30 & $\mathrm{xxxx}$ & $\mathrm{xxx}$ & $x \times x x x$ & $\mathrm{xxx}$ & $\mathrm{x}$ & & $\mathrm{xx}$ & & & $\mathrm{x}$ & & & & & & & $\mathrm{x}$ & & \\
\hline $55 \mathrm{R}-1,24-26$ & Siltstone & 442.24 & $x x x x$ & $\mathrm{xxxx}$ & $\mathrm{xxxx}$ & $\mathrm{xxx}$ & $\mathrm{xx}$ & & $\mathrm{xx}$ & & & $\mathrm{x}$ & & & $\mathrm{xx}$ & & & & $\mathrm{xx}$ & & \\
\hline $61 \mathrm{R}-1,129-131$ & Sandstone & 491.79 & $\mathrm{xxxx}$ & $x x x x$ & $\mathrm{xxx}$ & & $x x x x$ & & $\mathrm{xxx}$ & & & & & & & & & $\mathrm{xx}$ & $\mathrm{xxx}$ & & \\
\hline \multicolumn{22}{|l|}{ 139-857D- } \\
\hline IR-1, 137-139 & Siltstone & 582.87 & $x x x x x$ & $x x x x$ & $x x x$ & $\mathrm{xx}$ & & & & & & & $\mathrm{v}$ & & & & $\mathrm{xx}$ & $\mathrm{xx}$ & $\mathrm{x}$ & & \\
\hline $4 \mathrm{R}-2,75-77$ & Siltstone & 611.15 & $\mathrm{xxxx}$ & $x \times x x$ & $x x x x$ & $\mathrm{x}$ & & & & & & & $\mathrm{v}$ & & & $\mathrm{x}$ & $v-x x x$ & $x x x$ & $v-x$ & & \\
\hline $5 R-1,26-28$ & Silty claystone & 618.86 & & & & & & & & & & & $y-x x x x$ & $x x x x x$ & & & $v-x x x x$ & $\mathrm{xx}$ & $\mathrm{v}$ & $\mathrm{v}$ & \\
\hline $6 \mathrm{R}-1,20-22$ & Siltstone & 628.10 & $\mathrm{xxxx}$ ? & & $\mathrm{xxxx}$ & & & & & & & & $\mathrm{v}$ & & & $\mathrm{v}$ & $\mathrm{v}-\mathrm{xxx}$ & & & $x x x-v$ & \\
\hline $14 \mathrm{R}-1,22-25$ & Silty claystone & & $\begin{array}{l}x \times x \\
x \times x x\end{array}$ & $x x x x$ & $\begin{array}{l}x \times x \\
x \times x x\end{array}$ & & $\mathrm{xx}$ & & & & & & v & & & $\mathrm{v}$ & $x x x$ & $x x x$ & & & \\
\hline $15 \mathrm{R}-1,74-76$ & Silty claystone & 715.54 & $\begin{array}{l}\operatorname{minx} \\
\operatorname{xxxx}\end{array}$ & $\begin{array}{l}x x x x \\
\operatorname{xxxx}\end{array}$ & $\begin{array}{l}\operatorname{xinx} x \\
\operatorname{xxxx}\end{array}$ & $x$ & & & & & & & & & & $\mathrm{v}$ & $\begin{array}{l}x \times x \\
x \times x\end{array}$ & $\begin{array}{l}x \times x \\
x x x\end{array}$ & & & \\
\hline
\end{tabular}




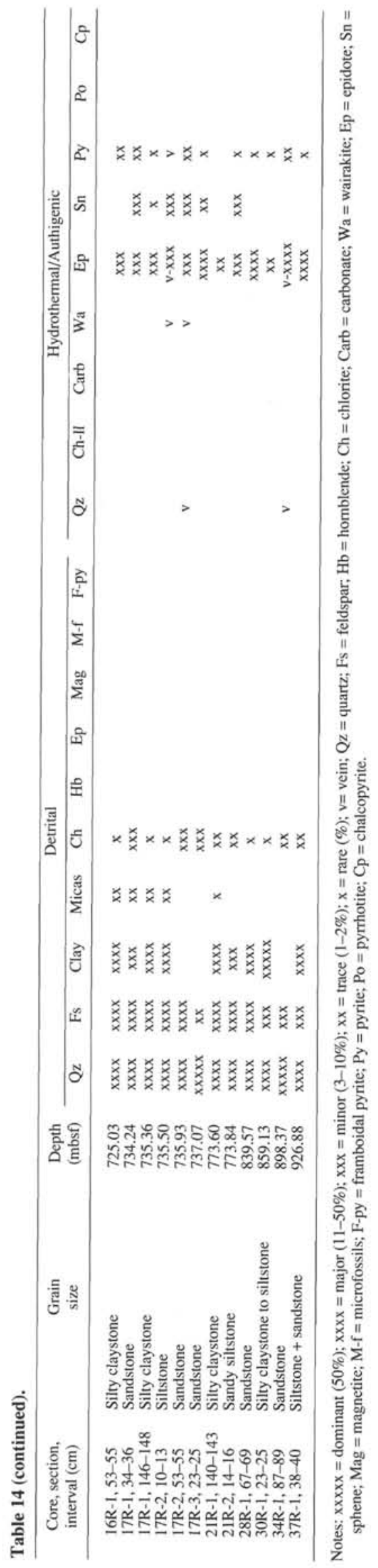

The pattern of mineral zonation outward from the core of the upflow system is reflected in sediment compositions (Goodfellow and Peter, this volume) and $\mathrm{Sr}$ isotope compositions (Goodfellow et al., in press).

The Mg content of chlorite generally increases with depth through Zones IVb to IIb in Holes $858 \mathrm{~A}$ and $858 \mathrm{C}$, indicating higher fluid/rock ratios near the highly permeable, fractured, and higher-temperature core of the upflow zone. The removal of $\mathrm{Mg}$ from seawater increases from $200^{\circ} \mathrm{C}$ to $300^{\circ} \mathrm{C}$, at which temperature it is virtually completely removed (Seewald et al., 1990). The alteration of illite and micas by chlorite is reflected by low $\mathrm{K}_{2} \mathrm{O}$ contents of bulk sediment (Goodfellow and Peter, this volume), in contrast to the $\mathrm{BH}$ upflow zone, where reaction with hydrothermal fluid has produced a chlorite-illite/muscovite assemblage.

Hydrothermal minerals near the core of the AAV upflow zone formed from $270^{\circ}$ to $300^{\circ} \mathrm{C}$ fluids with high Ca-activity. These fluids are similar in temperature and composition to vent fluids from AAV (Lydon et al., 1992). The low MgO content of Zone Ib indicates reaction of sediment with a "zero-Mg" end-member hydrothermal fluid (Seewald et al., 1990; Goodfellow and Peter, this volume). The high $\mathrm{Ca}$ activity of hydrothermal fluids accounts for the occurrence of wairakite and anorthitic plagioclase in the high-temperature core of the conduit. Seyfried et al. (1991) showed that the anorthite content of feldspar in equilibrium with hydrothermal fluids increases with increasing temperature.

Wirsching (1981) studied the experimental formation of calcium zeolites using different initial rock compositions and fluids with variable $\mathrm{Na}$ and $\mathrm{Ca}$ activities. This experimental work suggests that wairakite forms at high temperature either directly from a fluid with high $\mathrm{Ca}$ activity or by the transformation of analcime at low $\mathrm{Ca}$ activity. The high $\mathrm{Ca}$ activity of the hydrothermal fluid is supported by high $\mathrm{Ca} / \mathrm{Na}$ in both vent fluids (Lydon et al., 1992) and fluid inclusions (Peter et al., this volume) and by the absence of Na-phases such as analcime or albite. The high anorthite content of the plagioclase is consistent with low bulk-rock $\mathrm{Na}_{2} \mathrm{O}$ contents $(0.60 \mathrm{wt} \%$; Goodfellow and Peter., this volume).

Zone IVb at Site 858 is characterized by extensive-hydrothermal precipitation of Mg-smectite (bulk sediments have 17.9-34.2 wt\% $\mathrm{MgO}$; Goodfellow and Peter, this volume). Based on mineralogical data from shallow piston cores near vent sites at the AAV, it is most likely that these Mg-smectites are saponite (Turner et al., 1991; Goodfellow et al., in press). The formation of saponite is consistent with the massive dumping of $\mathrm{Mg}$ from seawater entrained locally into the zone of fluid upflow (Goodfellow et al., in press). Oxygen isotope data indicates that this saponite formed between $119^{\circ}$ and $134^{\circ} \mathrm{C}$ (Goodfellow et al., in press).

\section{Reaction Zone (Site 857)}

Site 857 consists of a thick sequence of interbedded hemipelagic and turbiditic sediments, and intercalated mafic sills. This site was drilled to test the hypothesis that the base of the sedimentary sequence represented a hydrothermal reservoir that supplied hydrothermal fluid to Site 858 (Davis, Mottl, Fisher, et al., 1992). The mineralogy, bulk chemical compositions (Goodfellow and Peter, this volume), and fluid inclusions all suggest that the reaction zone at Site 857 interacted with fluids similar to those venting at AAV. For example, fluid-inclusion temperatures measured in quartz and wairakite $\left(250^{\circ}-300^{\circ} \mathrm{C}\right)$ from Hole 857D are similar to those in wairakite from Hole 858F (Peter et al., this volume) and to vent fluid temperatures at Site 858 (Goodfellow and Franklin, in press). The mineral assemblage of the highest temperature zone at Site 857 (Zone Ic; wairakite-quartz-epidote-pyrite) is the same as the assemblage in the core of the upflow zone at Site 858 . Zone IIc at Site 857 and IIb at Site 858 likewise consist of quartz-chlorite-epidote-pyrite-sphene. The bulk sediment chemistry from the high temperature zones at both sites is also similar (Goodfellow and Peter., this volume). 


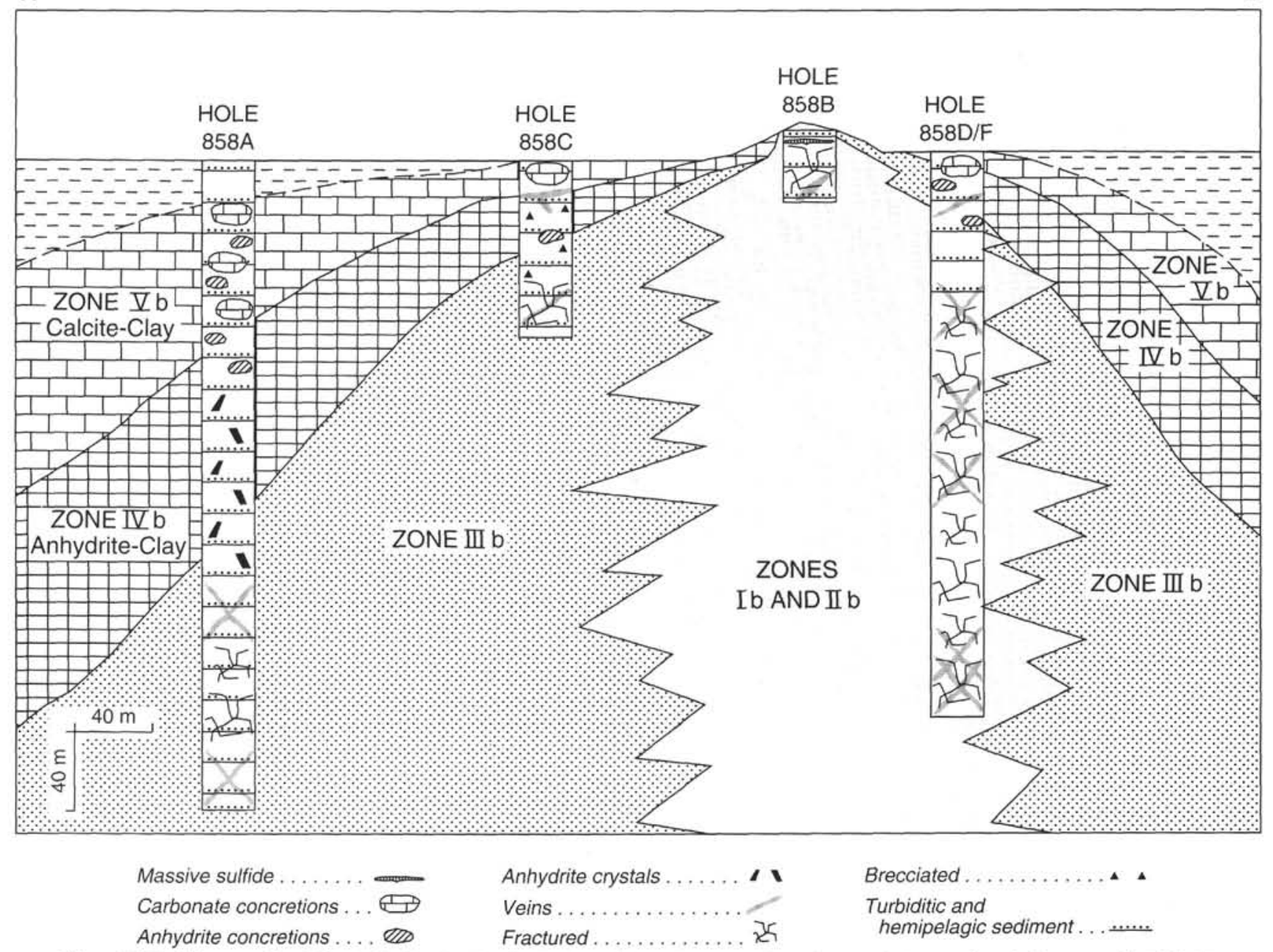

Figure 18. Profile across Site 858 (AAV) showing the distribution of alteration zones. Zone characteristics are given in the text and in Table 5.

Wairakite compositions also indicate a genetic link between the two sites. Wairakite from Hole $857 \mathrm{D}$ is more Ca-rich $(\mathrm{Ca} /(\mathrm{Ca}+\mathrm{Na})=$ $0.941-0.996)$ than wairakite from Hole $858 \mathrm{~F}(\mathrm{Ca} / \mathrm{Ca}+\mathrm{Na})=0.871-$ 0.967). This difference in $\mathrm{Na}$ contents of wairakite is consistent with the mixing of Ca-rich fluids generated at Site 857 with Na-bearing pore water or seawater in the upflow zone at Site 858 , and slightly higher fluid-inclusion temperatures in wairakite from Site 857 (Peter et al., this volume).

It is difficult to constrain the origin of the hydrothermal fluids, but it seems likely that the intrusions of sills into the sedimentary sequence has created a shallow hydrothermal circulation system that is feeding the nonmetalliferous vents at Site 858 and perhaps those presently venting at Site 856 . The sills are also highly altered (Davis and Fisher, this volume), and high-temperature (Zone Ic) veins crosscut both sills and sediment, indicating that alteration by hydrothermal fluids postdates the intrusions of the sills. There is no evidence for involvement of a high-temperature metalliferous fluid such as that which formed the Bent Hill massive sulfide deposit.

\section{CONCLUSIONS}

1. Site 856 represents a hydrothermally inactive upflow zone that is associated with the $\mathrm{BH}$ massive sulfide deposit. Hydrothermal alteration minerals at $\mathrm{BH}$ are zoned laterally from a high-temperature inner core assemblage to an outer low-temperature assemblage. Zone Ia is lithified and brecciated, and consists of quartz-(Fe)chlorite-muscovite-rutile-chalcopyrite-pyrrhotite. Zone IIa surrounds Zone Ia, is less altered and indurated, and consists of albite-chlorite-pyrite alteration. Zones IIIa and IVa are less intensely indurated than sediments from the higher-temperature inner zones and are characterized by anhydrite and calcite, respectively, in addition to illite and pyrite.

2. Site 858 (AAV) is a hydrothermal fluid discharge conduit that is venting fluids up to $276^{\circ} \mathrm{C}$. The core of this upflow zone consists of a wairakite-quartz-epidote-sphene-pyrite \pm plagioclase assemblage that formed at temperatures between $270^{\circ}$ and $290^{\circ} \mathrm{C}$ (Peter et al., this volume). Zone Ib is surrounded by hemipelagic and turbiditic sediment that becomes progressively less indurated and hydrothermally altered with distance from the center of fluid upflow. Zone $\mathrm{Ilb}$, which surrounds Zone $\mathrm{Ib}$, consists of quartz-epidote-pyrite. This zone is surrounded by Zone IIIb, which consists of albite-chlorite-pyrite. Outermost zones $\mathrm{IVb}$ and $\mathrm{Vb}$ are characterized by anhydrite and calcite, respectively.

3. Highly altered sediments in the core of the AAV upflow zone are characterized by the same mineral assemblage as that characterizing intensely altered sediment below $460 \mathrm{mbsf}$ at the postulated reaction zone (Site 857). Furthermore, the formation temperatures, mineral chemistry, and bulk sediment compositions are similar for the two alteration zones. The mineralogical, geochemical, and thermal similarities between the zones are consistent with the generation of AAV (Site 858) vent fluids from a hydrothermal reaction zone near the base of the Middle Valley sedimentary pile, probably related to sill intrusion.

4. The mineral assemblages at the core of the $\mathrm{BH}$ and AAV upflow zones are mineralogically distinct and have clearly formed 
from fluids of different temperature and composition. The alteration assemblage at $\mathrm{BH}$ was produced by an $\mathrm{Fe}-\mathrm{K}$-rich, high-temperature $\left(300^{\circ}-400^{\circ} \mathrm{C}\right)$ fluid with low $\mathrm{Ca}$ activity, whereas the core assemblage at AAV is the product of lower-temperature $\left(270^{\circ}-290^{\circ} \mathrm{C}\right)$ hydrothermal fluids with high $\mathrm{Ca}$ activity. In both upflow zones, mineral zonation and temperature gradients are controlled by the mixing of entrained seawater with upwelling and outwelling hydrothermal fluid.

\section{ACKNOWLEDGMENTS}

Bob Delabio is thanked for performing the XRD analyses, Laura Radburn for assistance with the SEM analyses, and Don Harris for help with the electron microprobe. We thank Martina Wecke for some of the drafting and Nancy McQuistion for editorial comments. We thank Jan Peter and Barry Cameron for discussions and for reviewing an earlier version of the manuscript. Reviews by J. Bruce Gemmell, Craig Leitch, and Michael Mottl improved earlier versions of the manuscript. This paper is Geological Survey of Canada Contribution No. 19293.

\section{REFERENCES *}

Adshead, J.D., Bornhold, B.D., and Davis, E.E., 1986. Indurated deposits and possible plume bands in a hydrothermal mound, northeast Pacific. Geol. Surv. Can. Curr. Res., 86-1A:737-748.

Al-Aasm, I.S., and Blaise, B., 1991. Interaction between hemipelagic sediment and a hydrothermal system: Middle Valley, northern Juan de Fuca Ridge, subarctic northeast Pacific. Mar. Geol., 98:25-40.

Cathelineau, M., 1988. Cation site occupancy in chlorites and illites as a function of temperature. Clay Mineral., 23:471-485.

Davis, E.E., Currie, R.G., and Sawyer, B.S., 1987. Marine geophysical maps of western Canada: regional SeaMARC II acoustic image mosaics and Sea Beam bathymetry. Geol. Surv. Can., Maps 2-1987 to 17-1987.

Davis, E.E., Goodfellow, W.D., Bornhold, B.D., Adshead, J., Blaise, B., Villinger, H., and Le Cheminant, G.M., 1987. Massive sulfides in a sedimented rift valley, northern Juan de Fuca Ridge. Earth Planet. Sci. Lett., 82:49-61.

Davis, E.E., and Lister, C.R.B., 1977. Heat flow measured over the Juan de Fuca Ridge: evidence for widespread hydrothermal circulation in a highly heat transportive crust. J. Geophys. Res., 82:4845-4860.

Davis, E.E., Mottl, M.J., Fisher, A.T., et al., 1992. Proc. ODP, Init. Repts., 139: College Station, TX (Ocean Drilling Program).

Davis, E.E., and Villinger, H., 1992. Tectonic and thermal structure of the Middle Valley sedimented rift, northern Juan de Fuca Ridge. In Davis, E.E., Mottl, M.J., Fisher, A.T., et al., Proc. ODP, Init. Repts., 139: College Station, TX (Ocean Drilling Program), 9-41.

Goodfellow, W.D., and Blaise, B., 1988. Sulfide formation and hydrothermal alteration of hemipelagic sediment in Middle Valley, northern Juan de Fuca Ridge. Can. Mineral., 26:675-696.
Goodfellow, W.D., and Franklin, J.M., in press. Geology, mineralogy and geochemistry of massive sulfides in shallow cores, Middle Valley, Northern Juan de Fuca Ridge. Econ. Geol.

Goodfellow, W.D., Grapes, K., Cameron, B., and Franklin, J.M., in press. Hydrothermal alteration associated with massive sulfide deposits, Middle Valley, Northern Juan de Fuca Ridge. Can. Mineral.

Lydon, J.W., Goodfellow, W.D., and Franklin, J.M., 1990. Chemistry of sediment pore waters around active hydrothermal vents, Middle Valley. Am. Geophys. Union, S. F. Progr. Abstr., 71:1569.

Lydon, J.W., Goodfellow, W.D., and Gregoire, D.C., 1992. Chemical composition of vent and pore fluids in an active hydrothermal discharge zone, Middle Valley. Geol. Surv. Can. Minerals Colloq., Progr. Abstr., Ottawa, 24.

Mottl, M.J., Holland, H.D., and Corr, R.F., 1979. Chemical exchange during hydrothermal alteration of basalt by seawater. II. Experimental results for $\mathrm{Fe}, \mathrm{Mn}$ and sulfur species. Geochim. Cosmochim. Acta, 43:869-884.

Rosenberg, P.E., 1967. Subsolidus relations in the system $\mathrm{CaCO}_{3}-\mathrm{MgCO}_{3}$ $\mathrm{FeCO}_{3}$ between $350^{\circ}$ and $550^{\circ} \mathrm{C}$. Am. Mineral., 52:787-798.

Schiffman, P., Bird, D.K., and Elders, W.A., 1985. Hydrothermal mineralogy of calcareous sandstones from the Colorado River delta in the Cerro Prieto geothermal system, Baja California, Mexico. Mineral. Mag., 49:435-449.

Seewald, J.S., Seyfried, W.E., and Thornton, E.C., 1990. Organic-rich sediment alteration: an experimental and theoretical study at elevated temperatures and pressures. Appl. Geochem., 5:193-209.

Seyfried, W.E., Jr., Ding, K., and Berndt, M.E., 1991. Phase equilibria constraints on the chemistry of hot spring fluids at mid-ocean ridges. Geochim. Cosmochim. Acta, 55:3559-3580.

Turner, R.J.W., Ames, D.E., Goodfellow, W.D., Leitch, C.H.B., Franklin, J.M., and Hoy, T., in press. Character of active hydrothermal mounds and nearby altered hemipelagic sediments in the hydrothermal areas of Middle Valley, northern Juan de Fuca Ridge: shallow core data. Can. J. Earth Sci.

Turner, R.J.W., Leitch, C.H.B., Ames, D.E., Hoy, T., Franklin, J.M., and Goodfellow, W.D., 1991. Character of hydrothermal mounds and adjacent sediments, active hydrothermal areas, Middle Valley sedimented rift, northern Juan de Fuca Ridge, northeast Pacific: evidence from ALVIN push cores. Geol. Surv. Can. Curr. Res., Pt. E., 99-108.

Von Damm, K.L., 1990. Seafloor hydrothermal activity: black smoker chemistry and chimneys. Annu. Rev. Earth Planet. Sci., 18:173-204.

Wirsching, U., 1981. Experiments on the hydrothermal formation of calcium zeolites. Clays Clay Miner., 29:171-183.

\footnotetext{
Abbreviations for names of organizations and publications in ODP reference lists follow the style given in Chemical Abstracts Service Source Index (published by American Chemical Society)
}

Date of initial receipt: 2 March 1993

Date of acceptance: 3 August 1993

Ms 139SR-220 


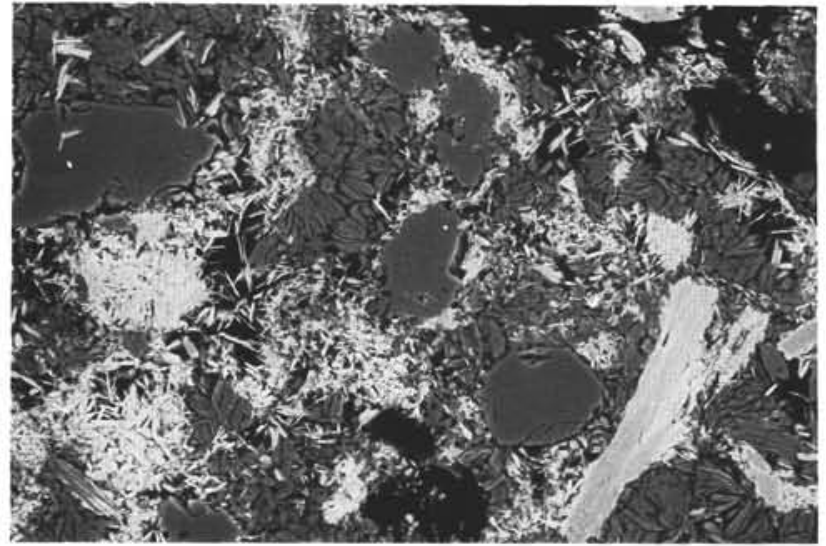

1

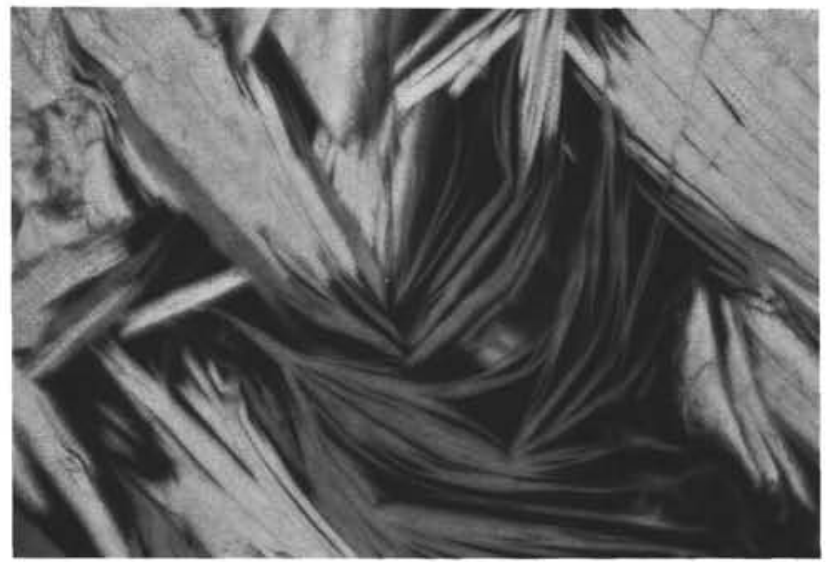

3

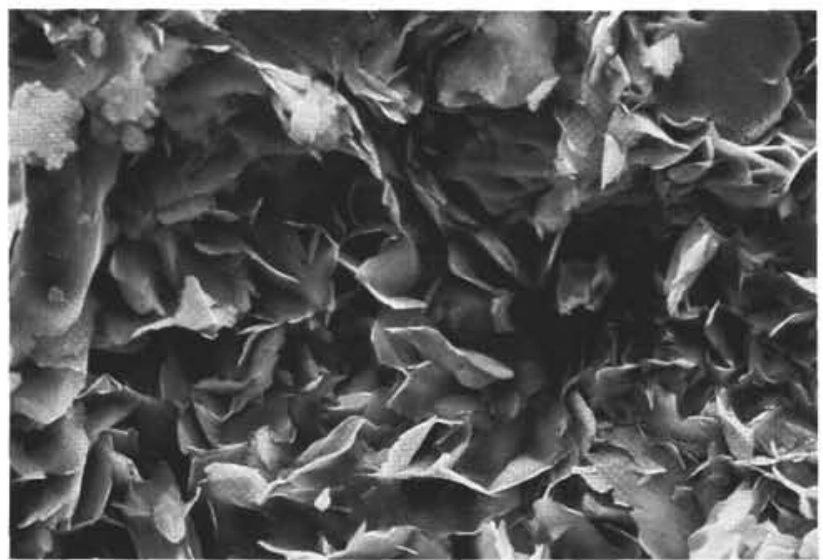

5

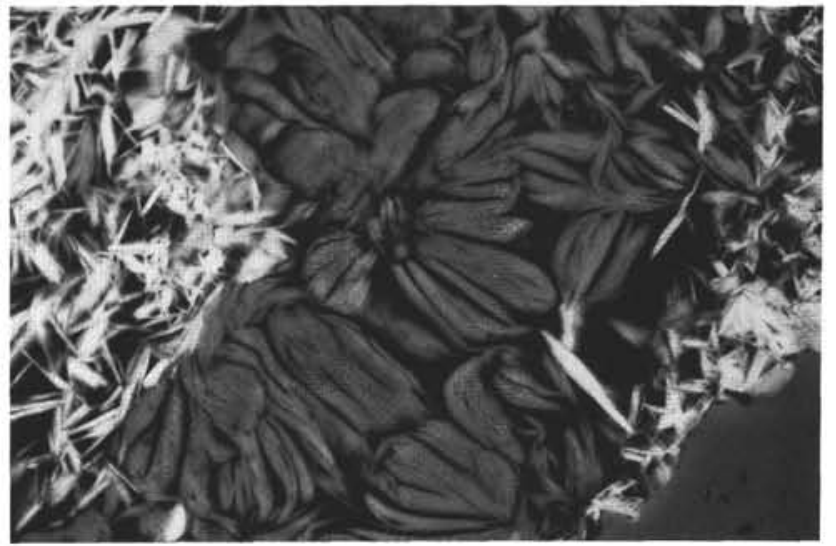

2

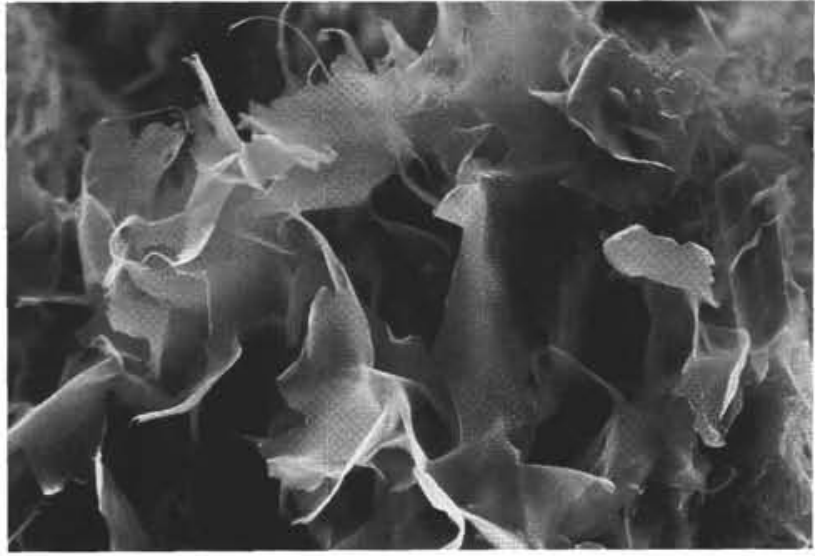

4

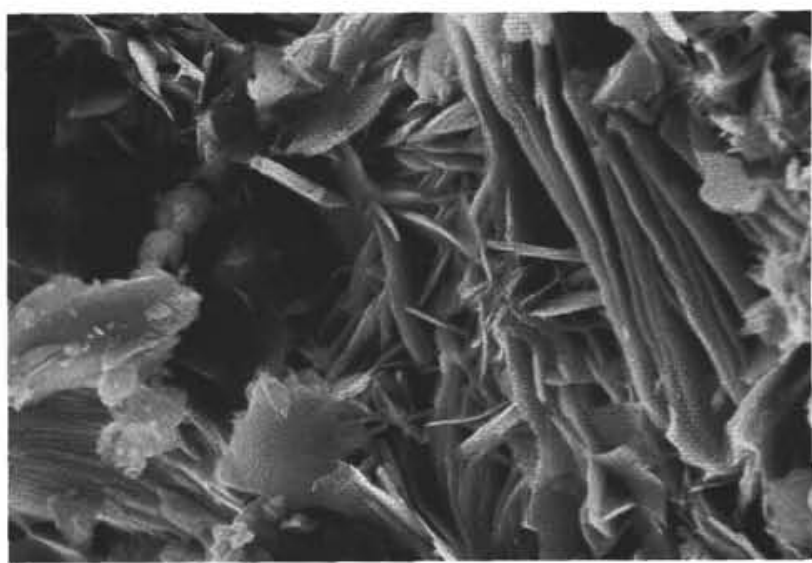

6

Plate 1. 1. Backscatter SEM image of authigenic Fe-chlorite (bright) and muscovite (dark, feathery texture) with authigenic quartz (dark). A large chlorite crystal at bottom right with darker $\mathrm{Mg}$-rich core, rimmed by brighter Fe-rich chlorite. Sample 139-856B-15X-1, 124-126 cm. Field of view (fov) =0.26 mm. 2. Backscatter SEM image of authigenic Fe-chlorite (bright) and muscovite (dark) with authigenic quartz (lower right). Sample 139-856B-15X-1, 124-126 cm; fov $=0.06$ $\mathrm{mm}$. 3. Backscatter SEM image of authigenic Fe-chlorite (bright) and muscovite (dark). Sample 139-856B-15X-1, 124-126 cm; fov =0.053 mm. 4. Secondary SEM image of illite/muscovite. Sample 139-856B-14X-4, 50-53 cm; fov $=0.072 \mathrm{~mm}$. 5. Secondary SEM image of muscovite with small chalcopyrite crystal in upper right corner. Sample 139-856B-15X-3, $8-10 \mathrm{~cm}$; fov $=0.078 \mathrm{~mm}$. 6. Secondary SEM image of muscovite crystals (right side) and chlorite crystals (bottom left). Sample 139-856B-15X-5, 106-108 cm; fov $=0.045 \mathrm{~mm}$. 


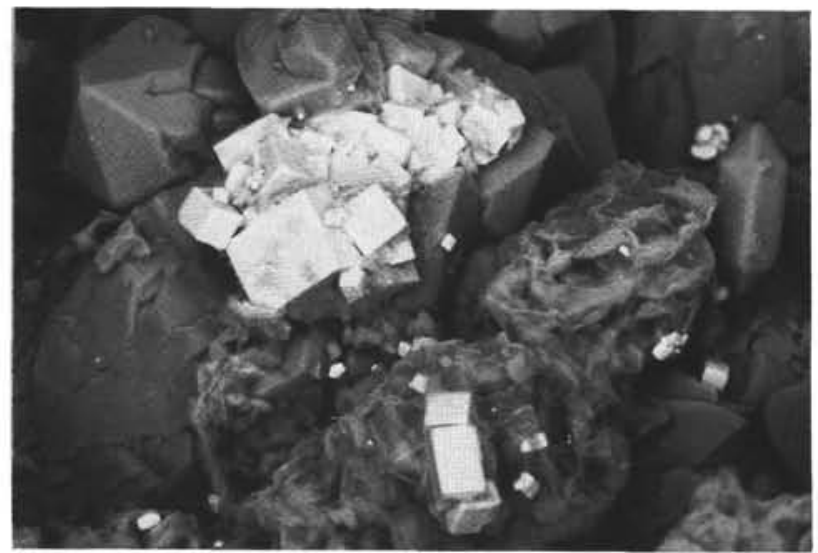

1

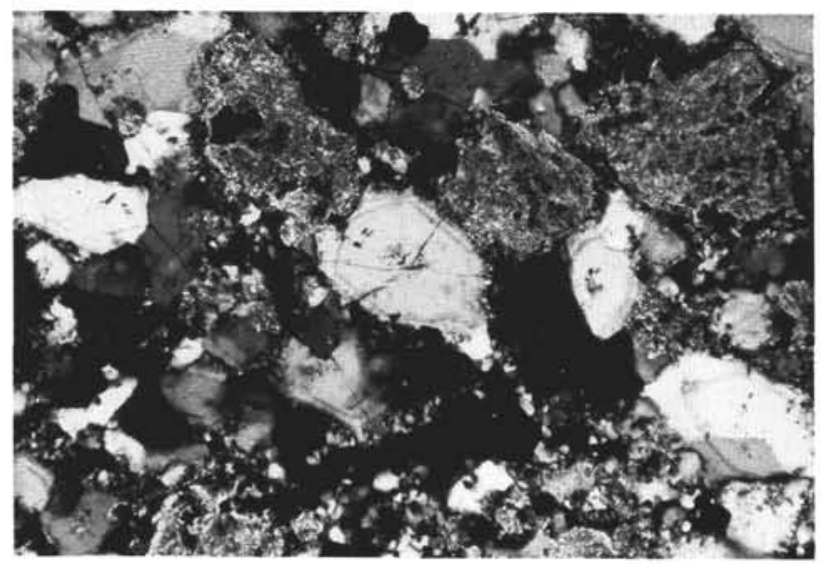

3

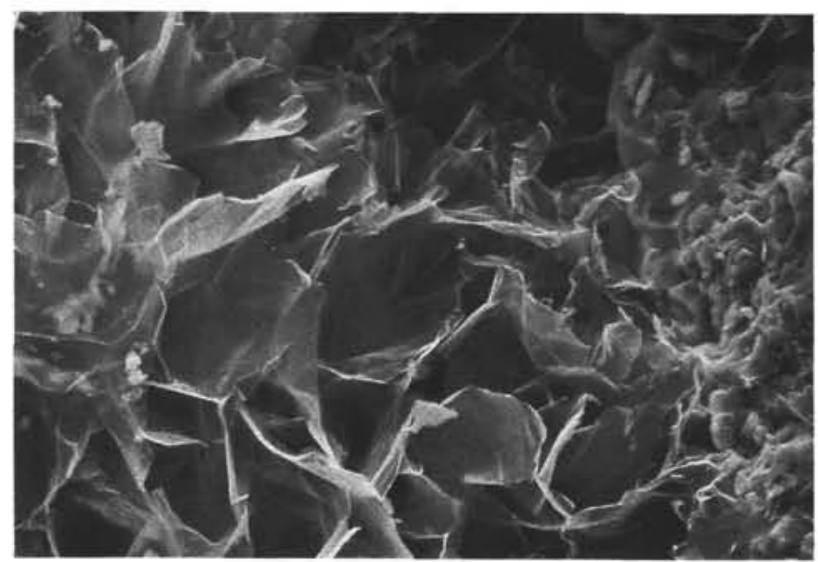

5

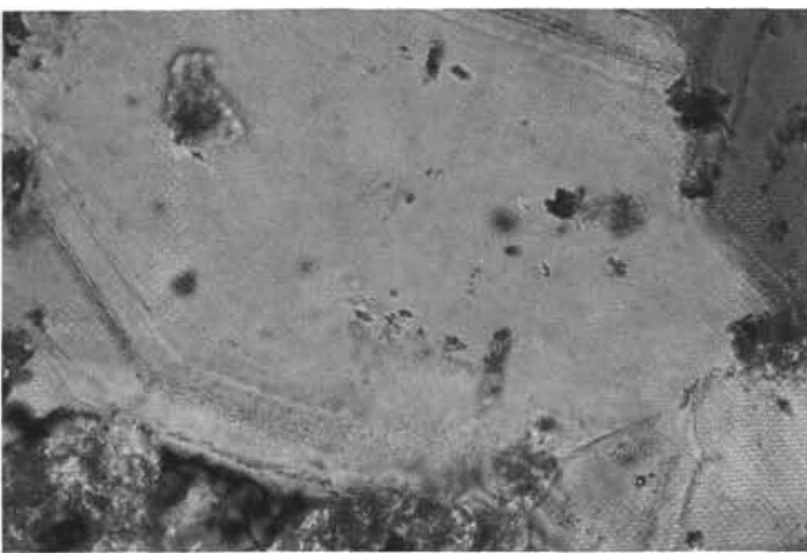

2

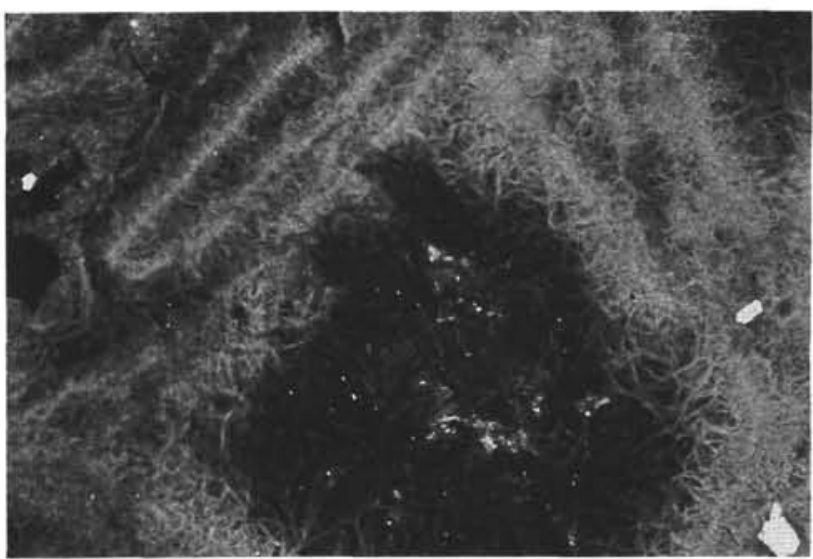

4

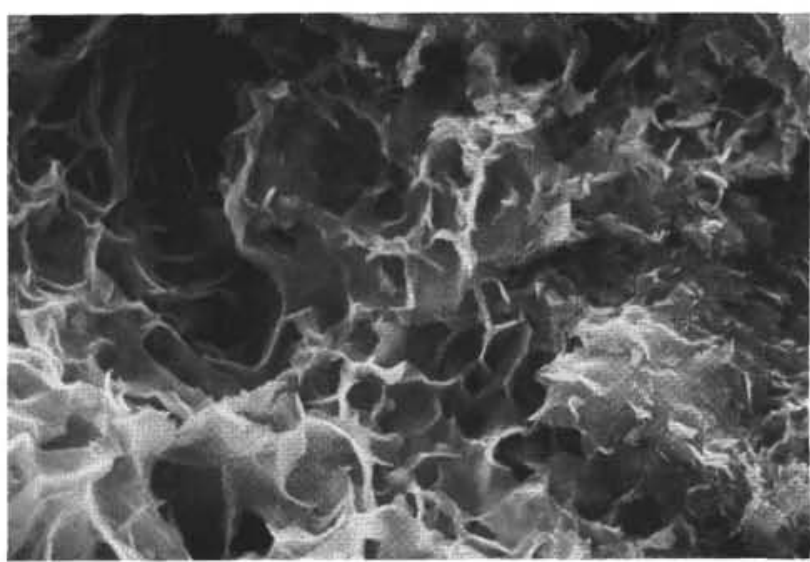

6

Plate 2. 1. Backscatter SEM image of hexagonal quartz, euhedral pyrite, and talc. Sample $139-856 \mathrm{D}-1 \mathrm{H}-2,43-46 \mathrm{~cm}$; fov $=0.150 \mathrm{~mm}$. 2. Photomicrograph of zoned hydrothermal quartz with talc. Sample 139-856G-2R-2, $84-86 \mathrm{~cm}$. Polarized transmitted light; fov $=0.23 \mathrm{~mm}$. 3. Photomicrograph of zoned hydrothermal quartz and clasts of talc with pyrite (black). Sample 139-856G-2R-2, 84-86 cm. Polarized transmitted light; fov $=0.92 \mathrm{~mm}$. 4. Backscatter SEM image of finely intergrown talc interstitial to collomorphic pyrite. Sample $139-856 \mathrm{~B}-3 \mathrm{H}-5,110-113 \mathrm{~cm}$; fov $=0.264 \mathrm{~mm}$. 5. Secondary SEM image of talc interstitial to collomorphic pyrite. Sample 139-856B-3H-5, 110-113 cm; fov $=0.068 \mathrm{~mm}$. 6. Secondary SEM image of talc interstitial to quartz and pyrite. Sample 139-856G$2 \mathrm{R}-2,54-56 \mathrm{~cm}$; fov $=0.034 \mathrm{~mm}$. 


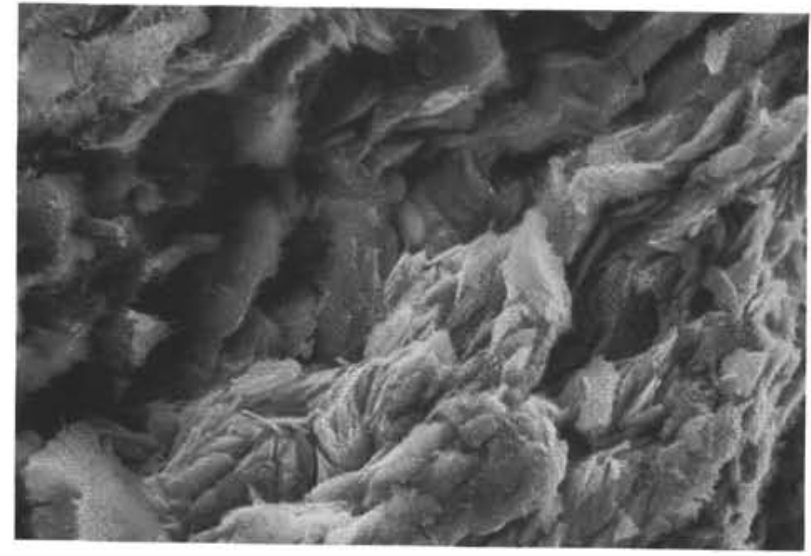

1

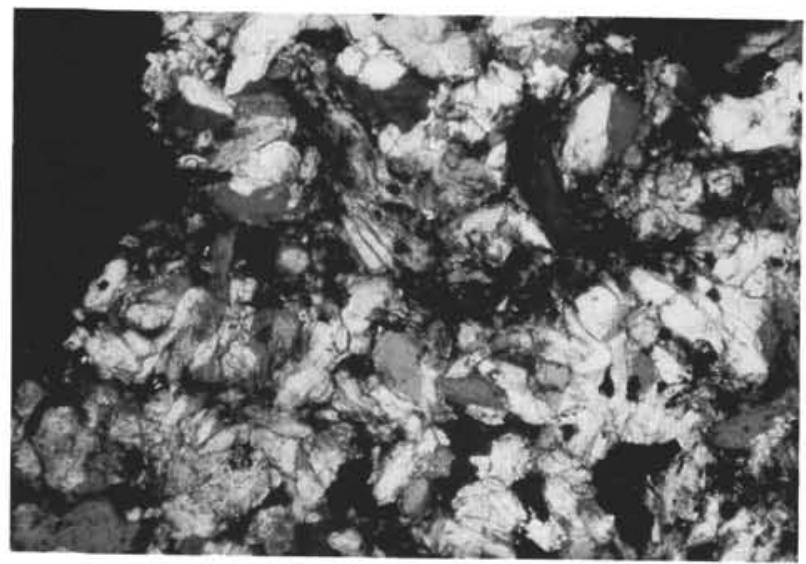

3

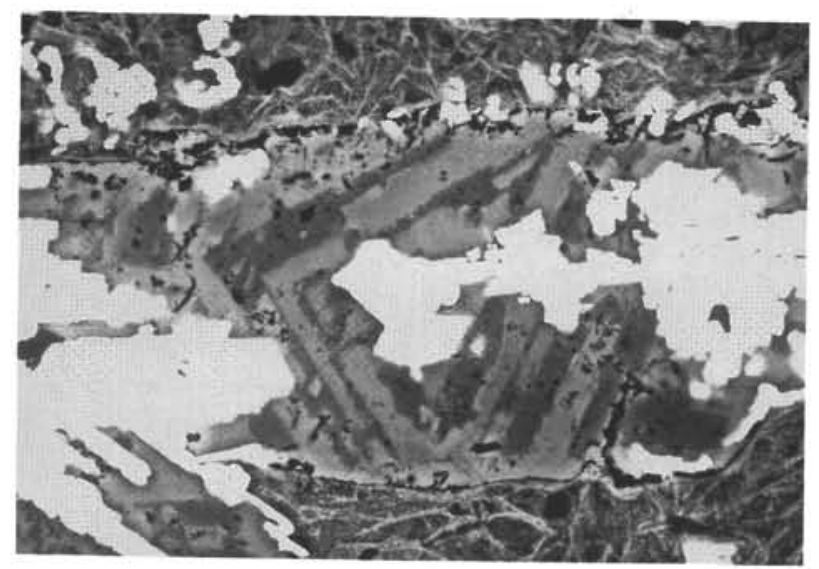

5

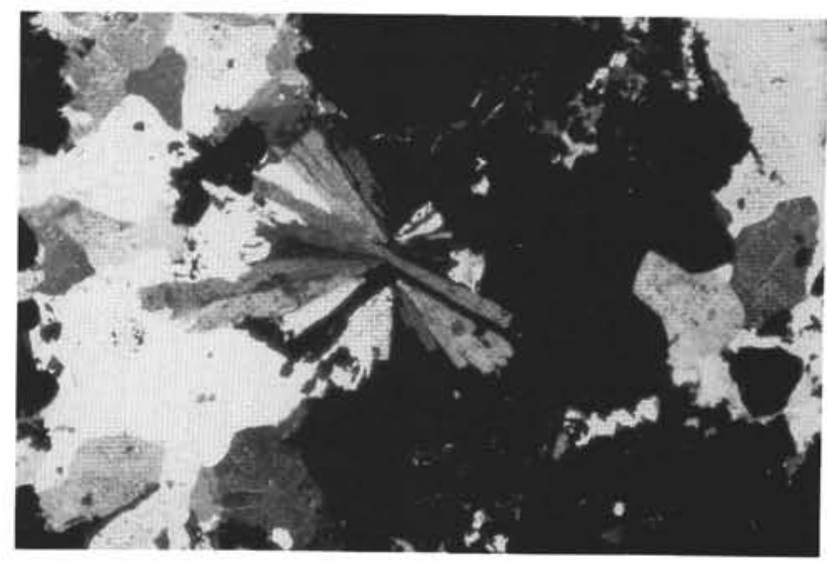

2

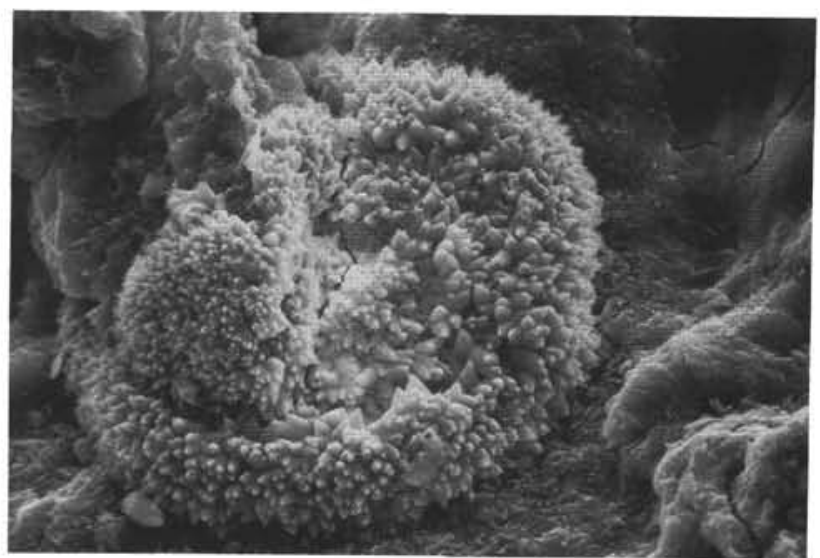

4

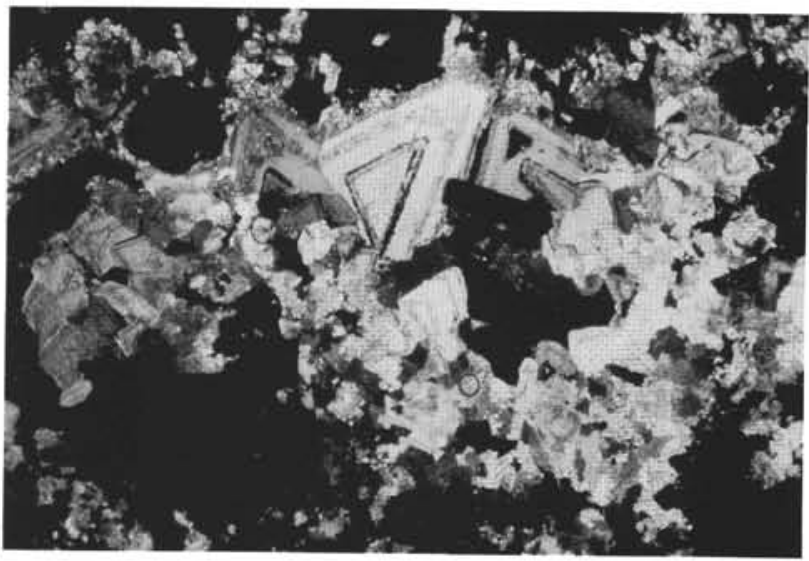

6

Plate 3. 1. Secondary SEM image of platy Mg-chlorite. Sample 139-856H-3R-3, 72-74 cm; fov $=0.052 \mathrm{~mm}$. 2. Photomicrograph of barite rosette in massive sulfide and carbonate. Sample 139-856H-3R-1, 28-30 cm. Polarized transmitted light; fov $=0.92 \mathrm{~mm}$. 3. Photomicrograph of magnesite interstitial to pyrite. Sample 139-856G-6R-3, 132-134 cm. Polarized transmitted light; fov $=0.92 \mathrm{~mm}$. 4. Secondary SEM image of calcite cluster on talc. Sample 139-856H-4R-1, $88-90 \mathrm{~cm}$; fov $=0.055 \mathrm{~mm}$. 5. Backscatter SEM image of zoned dolomite in vein crosscutting talc and overgrown by magnetite. Sample 139-856H-3R-3, 17-19 $\mathrm{cm} ;$ fov $=1.85 \mathrm{~mm}$. 6. Photomicrograph of zoned dolomite in vein crosscutting massive sulfide. Sample $139-856 \mathrm{H}-3 \mathrm{R}-3,72-74 \mathrm{~cm}$. Polarized transmitted light;
$\mathrm{fov}=0.095 \mathrm{~mm}$. 


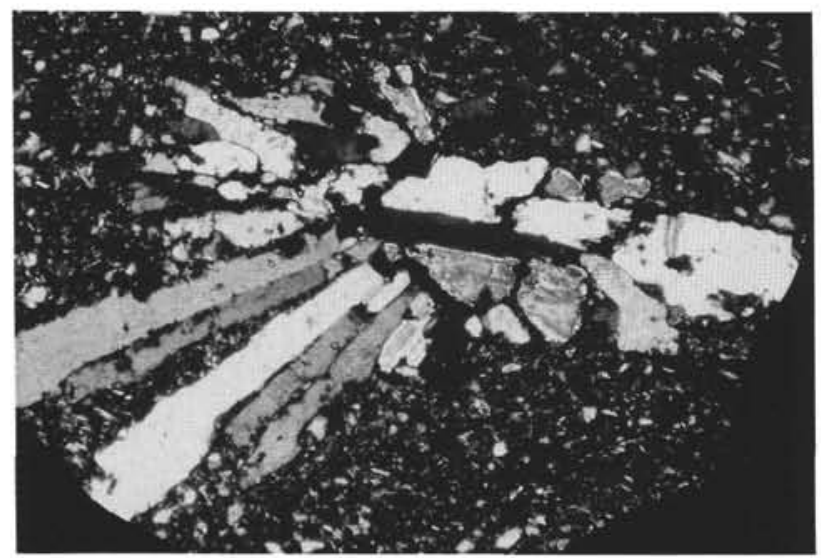

1

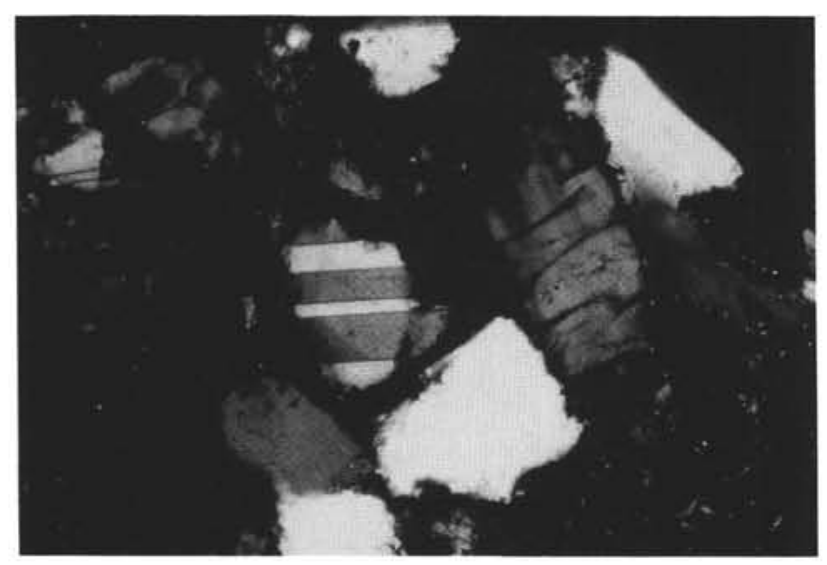

3

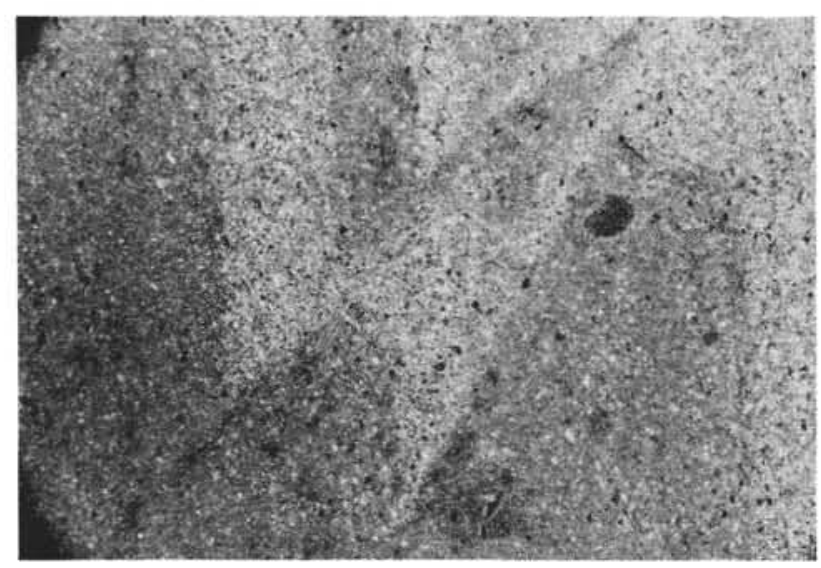

5

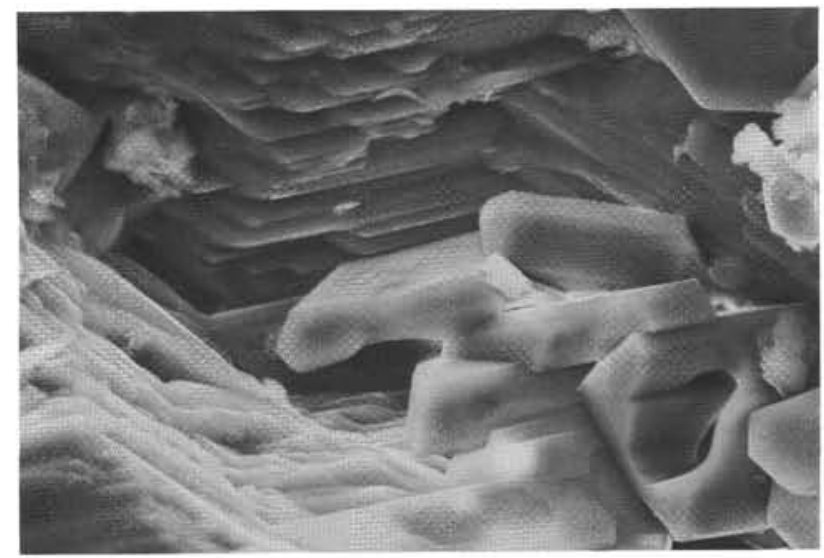

2

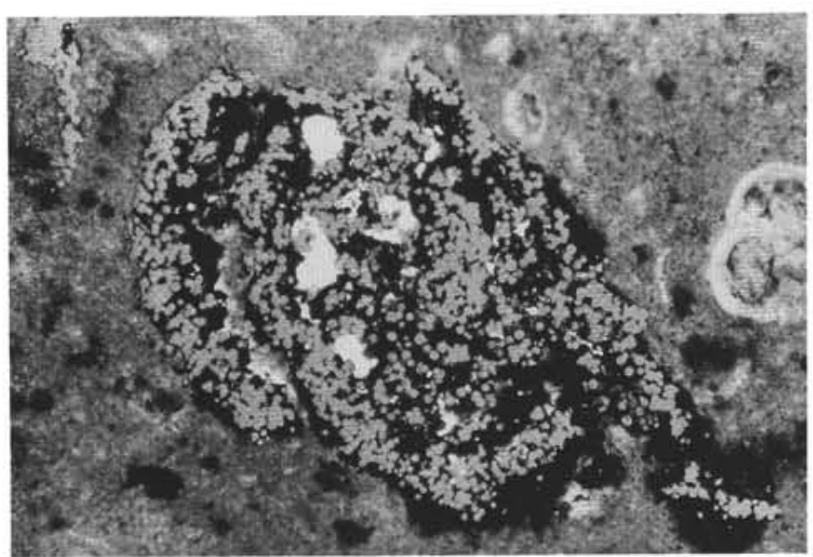

4

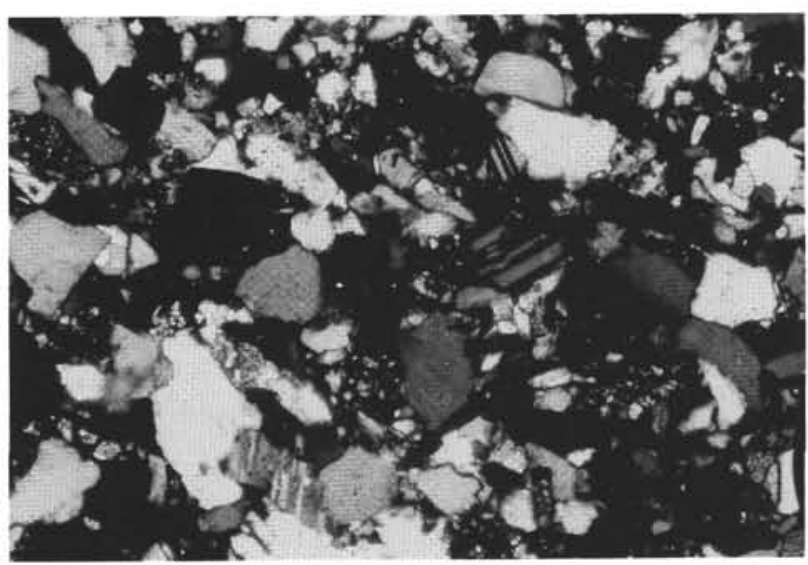

6

Plate 4. 1. Photomicrograph of anhydrite cluster in fine-grained sediment. Sample 139-858A-21X-2, 31-34 cm. Polarized transmitted light; fov =0.92 mm. 2. Secondary SEM image of stacked and cubic anhydrite. Sample 139-858A-24X-1,33-35 cm; fov $=0.075 \mathrm{~mm}$. 3. Photomicrograph of authigenic anorthite (twinned crystal), wairakite (dark), and quartz (bright). Sample 139-858F-9R-CC, 9-11 cm. Polarized transmitted light; fov $=0.46 \mathrm{~mm}$. 4. Photomicrograph of framboidal pyrite. Sample 139-857A-2H-3, 125-127 cm. Plain transmitted and reflected light; fov $=0.92 \mathrm{~mm}$. 5. Photomicrograph of offset of laminations in carbonate concretion by small microfault. Sample 139-857C-6R-1, 1-2 cm. Polarized transmitted light; fov $=1.85 \mathrm{~mm}$. 6. Photomicrograph of hydrothermally altered sandstone with twinned albite, quartz, epidote and sphene. Sample 139-857D-17R-1, 34-36 cm. Polarized transmitted light; fov $=0.46 \mathrm{~mm}$. 


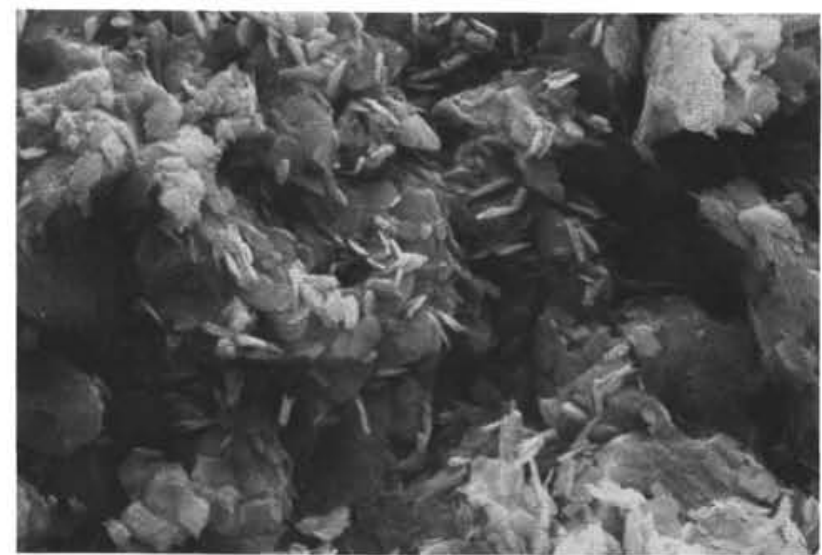

1

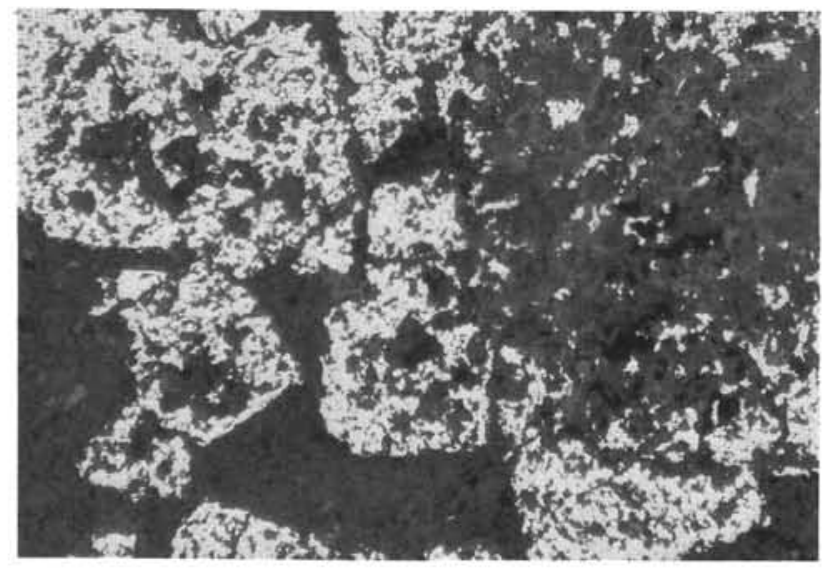

3

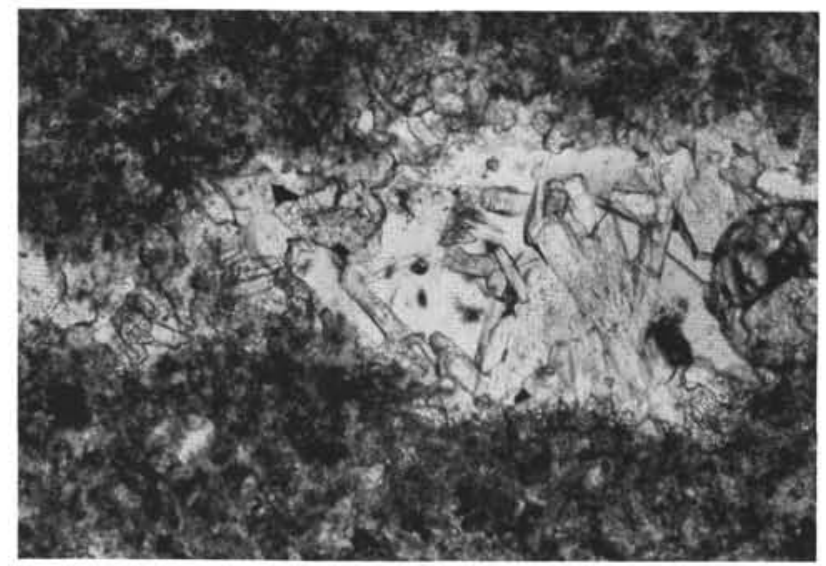

5

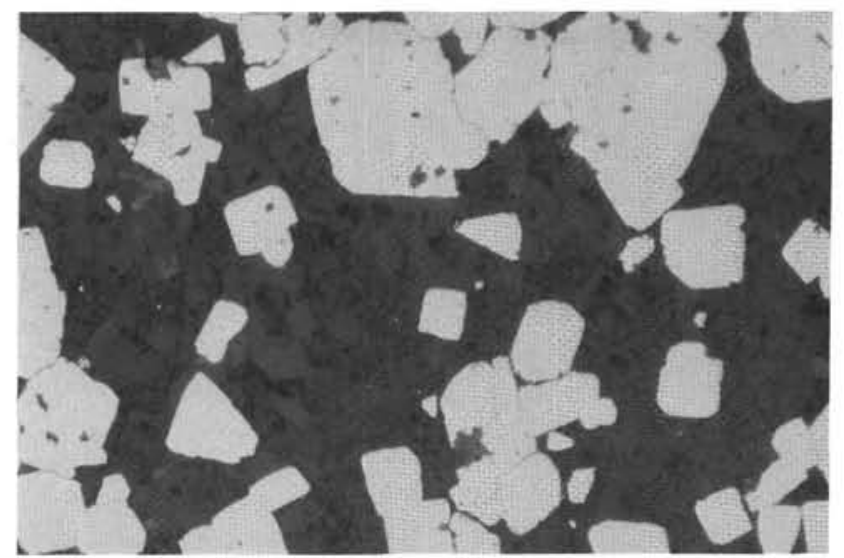

2

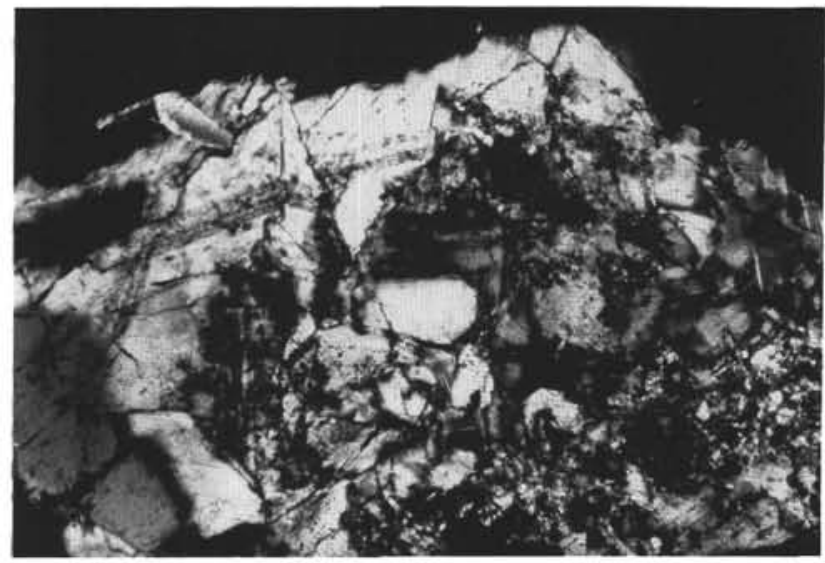

4

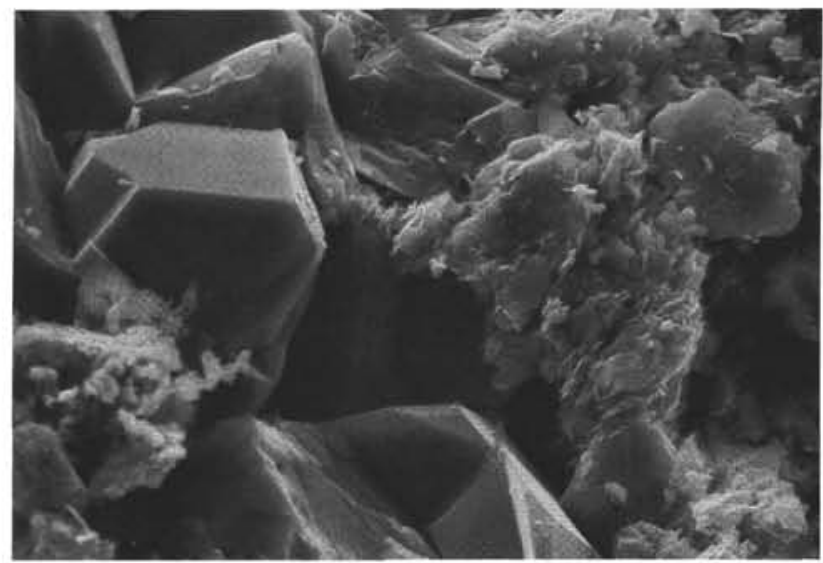

6

Plate 5. 1. Secondary SEM image of small chlorite plates on quartz. Sample $139-857 \mathrm{D}-5 \mathrm{R}-1,26-28 \mathrm{~cm}$; fov $=0.026 \mathrm{~mm}$. 2. Photomicrograph of authigenic pyrite in altered sediment. Sample 139-857C-61R-1, 129-131 cm. Reflected light; fov $=0.92 \mathrm{~mm}$. 3. Photomicrograph of corroded pyrite in altered sediment. Sample 139-857D-16R-1, 53-55 cm. Reflected light; fov =0.92 mm. 4. Photomicrograph of twinned wairakite in vein. Sample 139-857D-6R-1, 20-22 cm. Polarized transmitted light; fov $=1.85 \mathrm{~mm}$. 5. Photomicrograph of euhedral epidote with quartz in vein in altered sediment. Sample 139-857D-5R-1, 26-28 cm. Polarized transmitted light; fov $=0.46 \mathrm{~mm}$. 6. Secondary SEM image of hexagonal-shaped epidote in quartz vein crosscutting chlorite and quartz. Sample 139-857D-5R-1, 26-28 cm; fov $=0.050 \mathrm{~mm}$. 